GEAP-5724

AEC RESEARCH AND

DEVELOPMENT REPORT

SEPTEMBER 1968

\title{
BWR PRIMARY PIPING STRESSES FOR SYSTEM RELIABILITY ANALYSIS
}

W.F. ENGLISH

J.D. GILMAN

U.S. ATOMIC ENERGY COMMISSION

CONTRACT AT $(04-3)-189$

PROJECT AGREEMENT 37 


\section{DISCLAIMER}

This report was prepared as an account of work sponsored by an agency of the United States Government. Neither the United States Government nor any agency Thereof, nor any of their employees, makes any warranty, express or implied, or assumes any legal liability or responsibility for the accuracy, completeness, or usefulness of any information, apparatus, product, or process disclosed, or represents that its use would not infringe privately owned rights. Reference herein to any specific commercial product, process, or service by trade name, trademark, manufacturer, or otherwise does not necessarily constitute or imply its endorsement, recommendation, or favoring by the United States Government or any agency thereof. The views and opinions of authors expressed herein do not necessarily state or reflect those of the United States Government or any agency thereof. 


\section{DISCLAIMER}

Portions of this document may be illegible in electronic image products. Images are produced from the best available original document. 
GEAP-5724

AEC Research and Development Report

September 1968

\title{
BWR PRIMARY PIPING STRESSES \\ ' \\ FOR SYSTEM RELIABILITY ANALYSIS
}

\author{
W. F. English \\ J. D. Gilman
}

Approved:

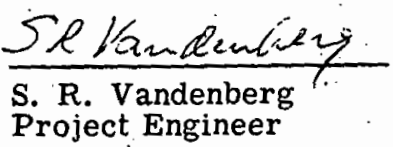

Prepared for the

U. S. Atomic Energy Commission Contract AT(04-3) - 189

Project Agreement 37
D. H. Imhoff, Manager

Development' Engineering
This report Late L L L NOTICE

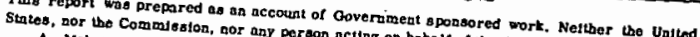

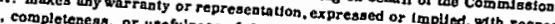

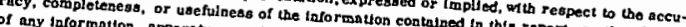

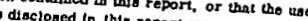
. Aspumes any uabs

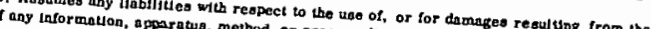
As uaed in the above, "persos actily on procesa dinclosed is tars repart.

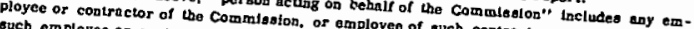

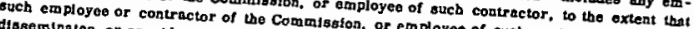

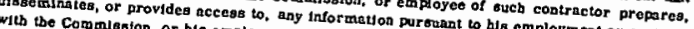

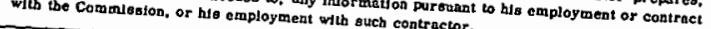




\section{LEGAL NOTICE}

This report was prepared as an account of Government sponsored work. Neither the United States, nor the Commission, nor any person acting on behalf of the Commission:

A. Makes any warranty or representation, expressed or implied, with respect to the accuracy, completeness, or usefulness of the information contained in this report, or that the use of any information, apparatus, method, or process disclosed in this report may not infringe privately owned rights; or

$B$. Assumes any liabilities with respect. to the use of, or for damages resulting from the use of any information, apparatus, method, or process disclosed in this report.

As used in the above, "person acting on bebalf of the Commission" includes any employee or contractor of the Commission, or employee of such contractor, to the extent that such employee or contractor of the Commission, or employee of sucb contractor prepares, disseminates, or provides access to, any information pursuant to bis employment or contract with the Commission, or bis employment with such contractor. 
TABLE OF CONTENTS

\begin{tabular}{|c|c|}
\hline & ABSTRACT \\
\hline \multirow[t]{4}{*}{ SECTION I } & INTRODUCTION \\
\hline & 1.1 Purpose \\
\hline & 1.2 Procedure \\
\hline & 1.3 Summary of Results \\
\hline \multirow[t]{8}{*}{ SECTION II } & STRESS CALCULATION MODEL OF PRIMARY PIPING \\
\hline & 2.1 Coordinate System \\
\hline & 2.2 Sub-Models \\
\hline & 2.3 Numbering of Joints \\
\hline & 2.4 Modeling of Components \\
\hline & 2.5 Modeling of Discontinuities \\
\hline & 2.6 Boundary Conditions \\
\hline & 2.7 MASS Flexibility Analysis \\
\hline \multirow[t]{5}{*}{ SECTION III } & TABULATION OF COMPONENTS AND DISCONTINUITIES \\
\hline & 3.1 Components \\
\hline & 3.2 Discontinuities \\
\hline & 3.3 Allowable Stresses \\
\hline & 3.4 Number of Cycles \\
\hline \multirow[t]{7}{*}{ SECTION IV } & STRESS CALCULATIONS AND RESULTS \\
\hline & 4.1 Thermal Expansion Stress \\
\hline & 4.2 Weight Stress \\
\hline & 4.3 Earthquake Stress \\
\hline & 4.4 Impact Stress \\
\hline & 4.5 Transient Thermal Stress \\
\hline & 4.6 Vibration Stress \\
\hline \multirow[t]{4}{*}{ SECTION V } & APPLICATION TO CRACK INITIATION AND CRACK \\
\hline & PROPAGATION STUDIES \\
\hline & 5.1 Sources of Cyclic Stress \\
\hline & 5.2 Simplified Interpretation of Piping Stresses \\
\hline \multirow[t]{7}{*}{ APPENDIX A } & MASS TUBING STRESS CALCULATION NO. 1052 \\
\hline & A. 1 Longitudinal Bending Stress, $\mathrm{S}_{\mathrm{B}}$ \\
\hline & A. 2 Axial Stress, $s_{A}$ \\
\hline & A. 3 Torsional Stress, $\mathrm{S}_{\mathrm{T}}$ \\
\hline & A. 4 Pressure Stresses \\
\hline & A. 5 Combined Stresses \\
\hline & A. 6 Comparison of Stress Calculation 1052 with ASA Code \\
\hline \multirow[t]{3}{*}{ APPENDIX B } & $\begin{array}{l}\text { TABULATION OF COMPONENTS AND DISCONTINUITIES IN } \\
\text { A TYPICAL. SINGLE-CYCLE BWR }\end{array}$ \\
\hline & REFERENCES \\
\hline & DISTRIBUTION \\
\hline
\end{tabular}




\section{LIST OF ILLUSTRATIONS}

$\underline{\text { Figure }}$

Title

$\underline{\text { Page }}$

2

3

4

5

6

7
MASS Sub-Model No. 1

3

MASS Sub-Model No. 2

MASS Sub-Model No. 3

MASS Sub-Model No. 4

MASS Sub-Model Nos. 5 and 8

MASS Sub-Model No. 6

MASS Sub-Model No. 7

Arrangement of Recirculation Loops

Recirculation Loop Numbering

MASS Model of a Piping Tee

MASS Model of a Reducer

Coefficients of Expansion

Flowmeter

Distribution of Component Stresses

Distribution of Component Stresses

Distribution of Cross-Sectional Flow Areas

Distribution of Cross-Sectional Flow Areas

Plot of Earthquake Epicenters

Seismic Probability Map

Earthquake Acceleration Response Spectrum

Earthquake Velocity Response Spectrum

Fatigue Data-Carbon Steels

Fatigue Data-Stainless Steels

Fatigue Data-Low-Alloy Steels
4

5

5 


\section{ABSTRACT}

The results of a detailed stress analysis of a typical BWR primary piping system are presented, for use in a determination of the system reliability during its design lifetime. Stresses resulting from normal and abnormal conditions are calculated, and analytical models are discussed. Results are tabulated for each piping component in the system.

\section{SECTION I}

\section{INTRODUCTION}

\subsection{PURPOSE}

The purpose of this report is to provide a tabulation of all components included in the primary piping system of a typical singlecycle boiling water reactor, and the design calculation model for determining the stresses in these components. This information will be used in the estimation of the reliability of the piping system, which is the objective of the Reliability Engineering Task of the Pipe Rupture Study.

\subsection{PROCEDURE}

A typical single-cycle BWR was chosen as the reference system. A flexibility analysis model using the MASS ${ }^{(7)}$ computer code was constructed from available drawings.

The thermal expansion stresses were calculated, disregarding the effects of pipe weight and pipe-supporting hangers. The temperature change encountered during normal operation which would yield the maximum stresses was imposed on each system. The longitudinal expansion due to internal pressure was considered by an additional temperature change which gives an equivalent axial strain. With these conditions, the MASS stress calculation No. 1052 yields a stress equal to $S_{E}$ of the ASA B31. 1 - 1955 piping coode (see Appendix A).
Possible hanger and sway brace locations were chosen using the selection procedures outlined in Reference 1. Weight stresses were then calculated for the piping system, using a lumped mass model. Earthquake stresses were calculated using the same model but applying horizontal static forces equivalent to $0.43 \mathrm{~g}$. The earthquake loading was assumed to be typical of that which might occur in the North Atlantic states of the U. S. Transient pressure and thermal stresses were calculated for various modes of plant operation, assuming both normal and accident conditions, at critical locations within the piping system.

\section{3 SUMMARY OF RESULTS}

The tabulation indicates there are approximately 800 components in the primary piping. A comparison of the nominal expansion stresses with the allowable stresses shows that most systems are extremely flexible. However, the shorter of the two primary core spray lines has stresses equal to the allowable stress. Primary stresses (pressure, weight, earthquake, and vibration) can be controlled by proper choice of pipe support and support location. By following procedures outlined in Reference 1 for choice and location of supports, it was found that no primary stresses exceeded the allowable stress. 


\section{SECTION II}

\section{STRESS CALCULATION MODEL OF PRIMARY PIPING}

The stress calculation model of the primary piping of a single-cycle BWR, suitable for use with the MASS computer code, is based on a typical boiling water reactor plant. Layouts of most of the primary system were taken from drawings of a relatively standard BWR. However, for some systems where the appropriate drawings were not available, it was necessary to use for reference the drawings from another similar reactor.

\subsection{COORDINATE SYSTEM}

The coordinate system for locating MASS joints has its origin at the center of curvature of the hemisphere that describes the bottom head. The " $x$ " axis is positive upwards along the centerline of the pressure vessel, the "y" axis is positive westward, and the " $z$ " axis is positive southward. The orientation is shown in Figures 1 through 8 .

\subsection{SUB-MODELS}

Because of the limited capacity of MASS, it was necessary to divide the primary piping model into sub-models. The sub-model number given in Table 1 refers to which of eight independent models the system is included. The sub-models are independent because the stresses of piping in one sub-model are not influenced by the stiffness and deflections of lines in another unless the deflections are extremely large and the pipes interact.

\subsection{NUMBERING OF JOINTS}

The numbering of the MASS joints is shown in Figures 1 through 9. Only the joints necessary to clarify the system are included in the illustrations. The range of joint numbers for each line is given in Table 1 . No joint number is used more than once in a particular sub-model, but some numbers are repeated in other sub-models. Therefore, when referring to a MASS joint number, it is necessary to state both the joint number and the sub-model number.

\subsection{MODELING OF COMPONENTS}

A component can be described as a part of the system that is represented by more than a single joint. The tubing input of MASS is used for modeling sections of straight pipe, elbows, bends, and valves. Equipment such as pumps, heat exchangers, and filters is assumed to be extremely stiff and is modeled by rigid connectors.

For the piping sections (straights, elbows, and bends), the nominal diameter and material were determined from the system piping and instrumentation diagram. The schedule number was taken as 80 if the line was designed for high pressure and temperature, or 40 if designed for low pressure and temperature. Exceptions were the recirculation lines and poison spray system, where the outside diameter and thickness were specified directly.

Valves were given the same outside radius as the piping in which they were included. To increase stiffness, the valve sections were given a thickness equal to half the outside radius. This results in a moment of inertia equal to 0.937 times that of a solid cylinder.

\subsection{MODELING OF DISCONTINUITIES}

For the MASS model, discontinuities can be established by a single joint. Tees and wyes are modeled as three sections of 
GEAP-5724

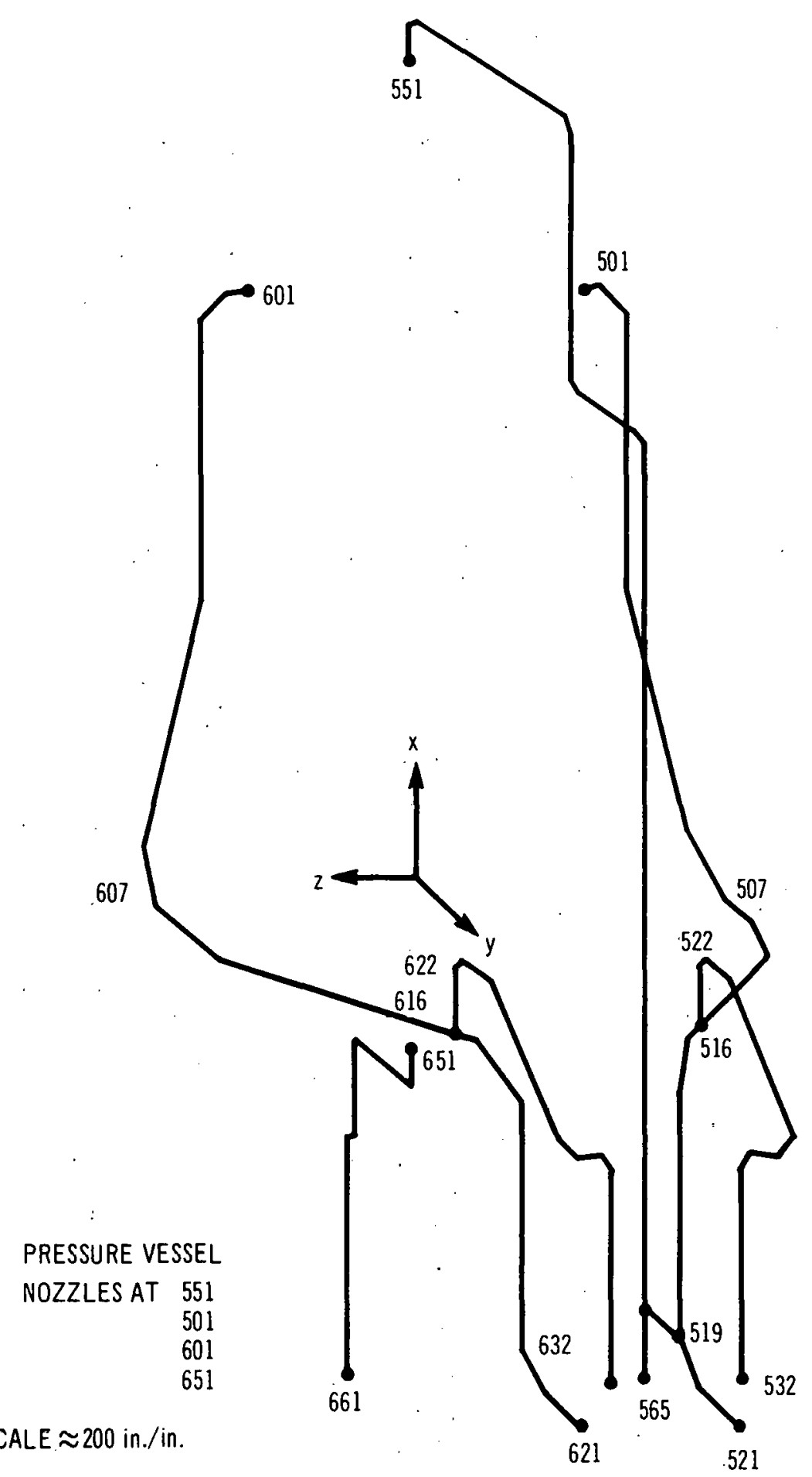

FIGURE i. MASS SUB-MODEL No. 1 


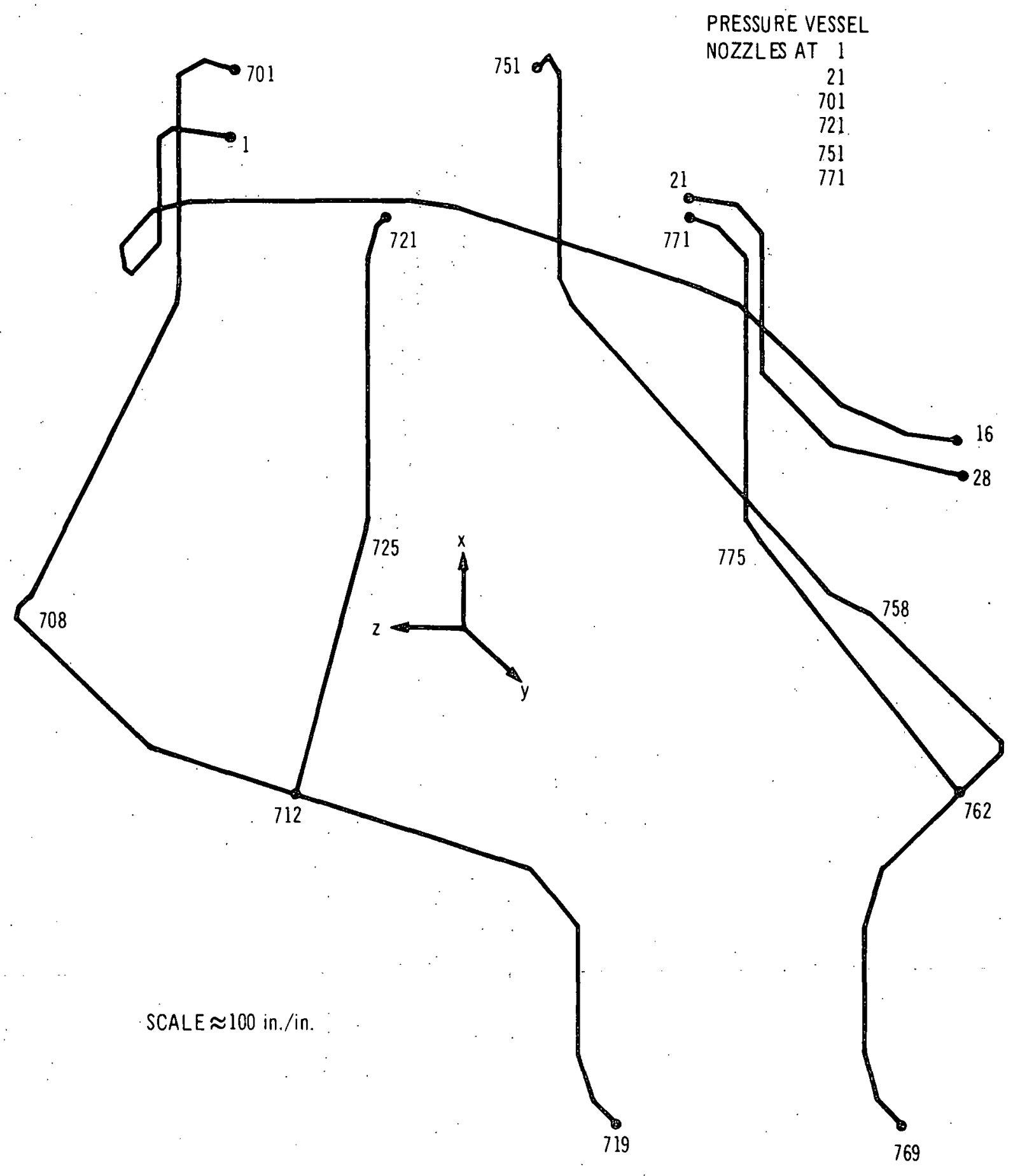

FIGURE 2. MASS SUB-MODEL No. 2 


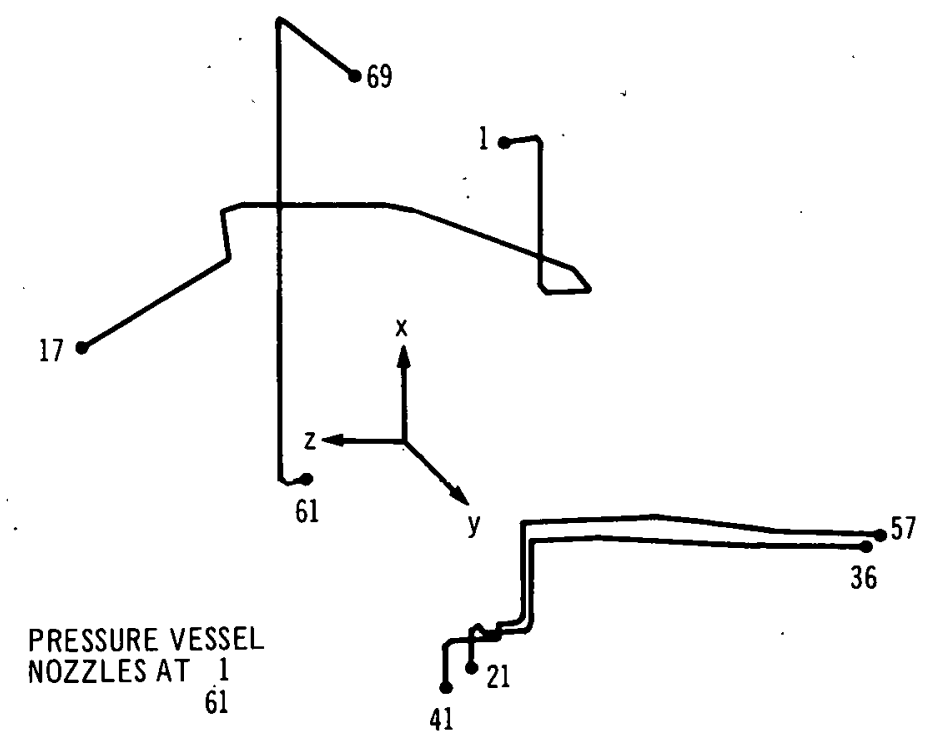

CONTROL ROD DRIVE THIMBLES AT 21

SCALE $\approx 200 \mathrm{in} . / \mathrm{in}$.

FIGURE 3. MASS SUB-MODEL No. 3

PRESSURE VESSEL

NOZZLES AT 161

261

EMERGENCY CONDENSER

ATTACHMENTS AT 186

196
286

296

SCALE $\approx 200 \mathrm{in} . / \mathrm{in}$.
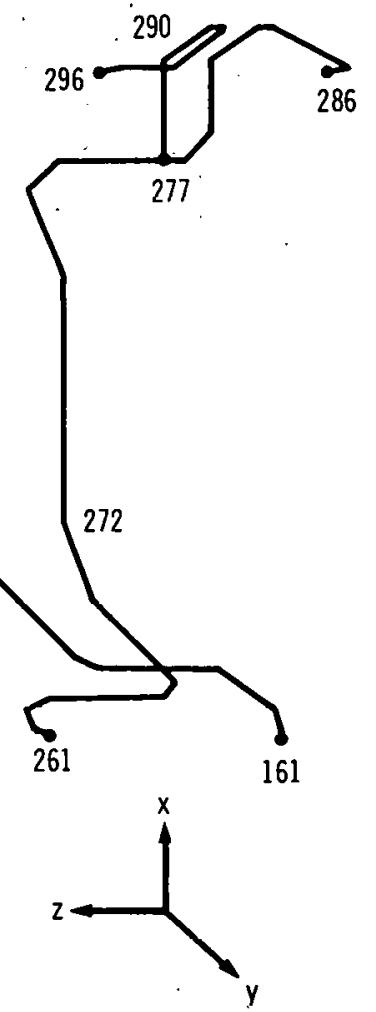

FIGURE 4. MASS SUB-MODEL No. 4 


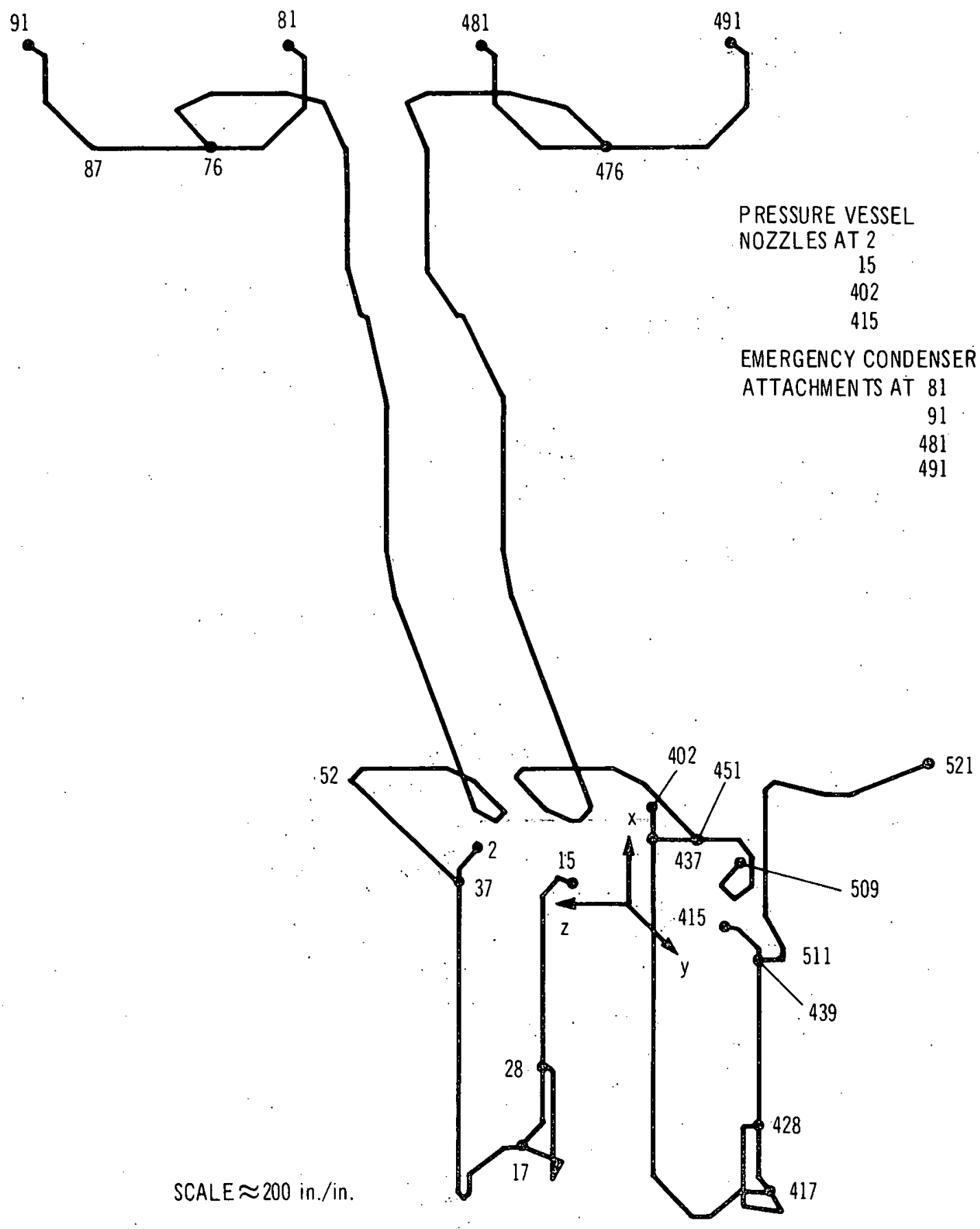

FIGURE 5. MASS SUB-MODELS NOS. 5 AND 8 


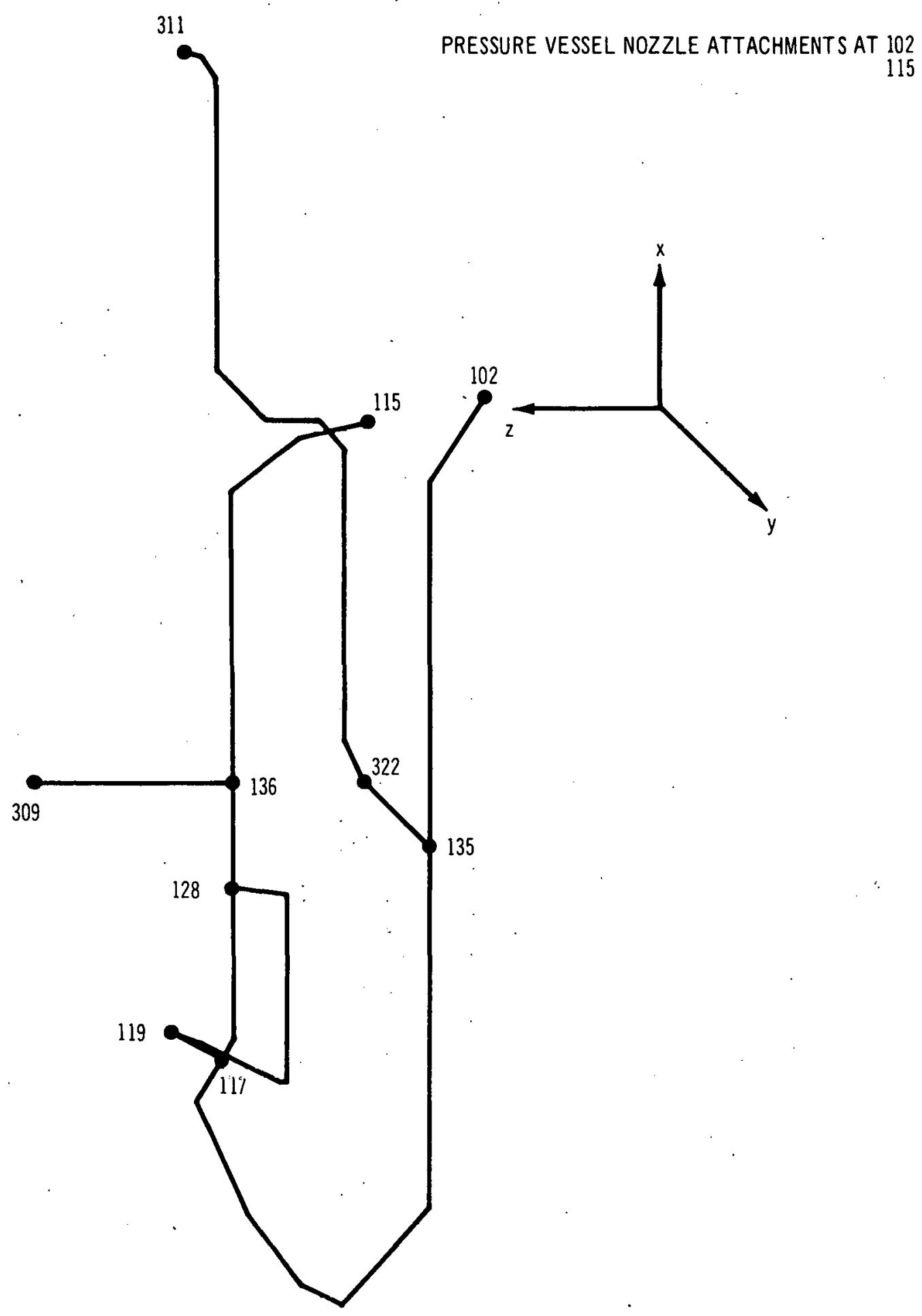

FIGURE 6. MASS SUB-MODEL NO. 6 
GEAP-5724
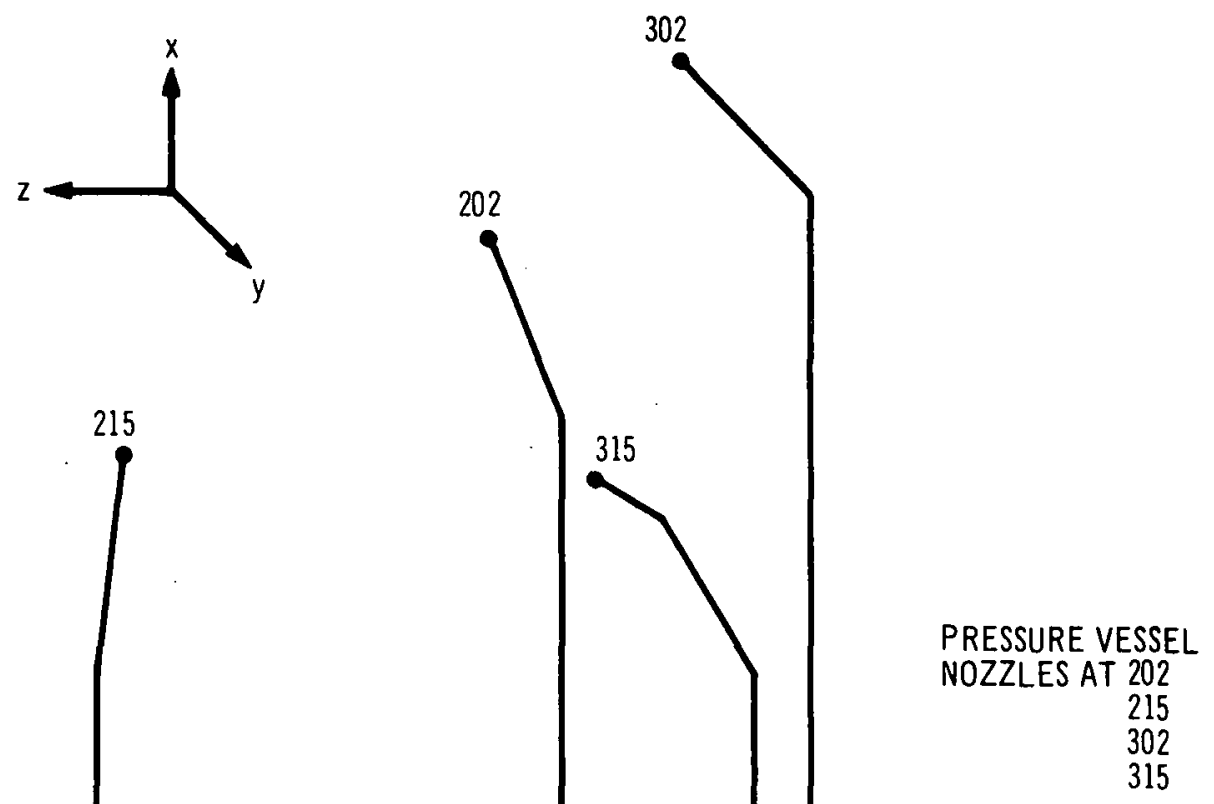

SCALE $\approx 80 \mathrm{in} . / \mathrm{in}$.

FIGURE 7, MASS SUB-MODEL No. 7

$-8-$ 


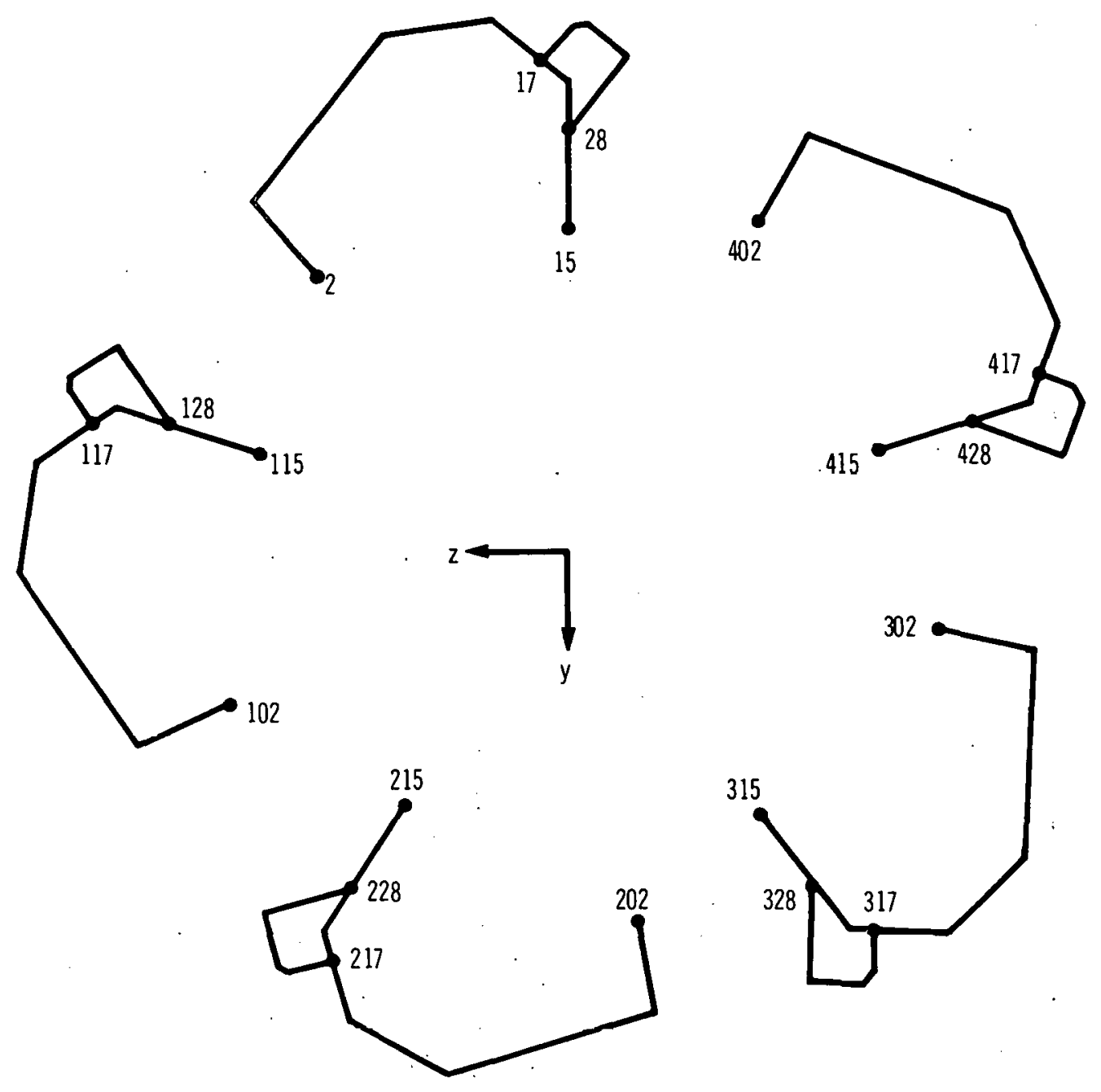

SCALE $\approx 80$ in./in. 


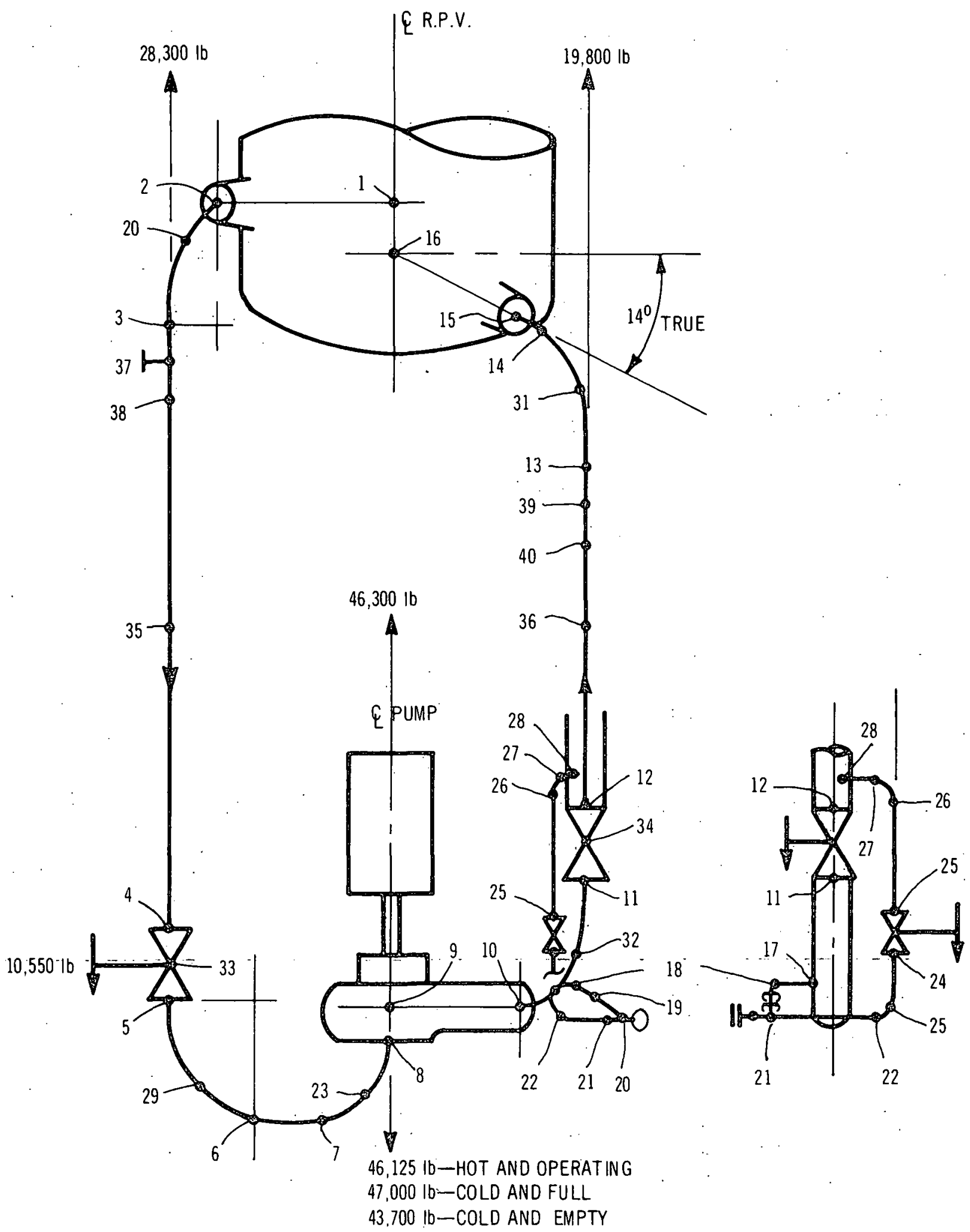

FIGURE. 9. RECIRCULATION LOOP. NUMBERING 
TABLE 1

RANGE OF MASS JOINT NUMBERS AND COMPONENT

,

Sub-Model

No.

1

2

3

Control Rod Drive

P.V. to C.R. D. System

Insert (Thimble to D.W.)

Withdraw (Thimble to D.W.)

Poison Spray

(P.V. to I. V. )

Emergency Condenser Steam

North Side

Main Line P.V. to Branch Lines

P.V. to Branch Lines

161-177

501-516

Branch a to condenser

177-186

$517-525$

Branch $b$ to condenser

South Side

Main Line

P. V. to Branch Lines

Branch a to condenser

Branch $b$ to condenser

MASS Joint
No.

$501-521$

$516,522-532$

601-621

$616,622-632$

$551-565$

563-519

651-661

1-16

21-28

701-719

301-318

321-325

351-368

371-375

771-775, 762
401-416

421-435.

441-456

$461-468$
526-532

551-566

567-575

576-582 
TABLE 1 (Continued)

Sub-Model

No.

5

Piping System

Recirculation Loop No. 1

Main Line

Bypass

Emergency Condenser Condensate South Side (No. 1)

From Recirc. Loop 1

Branch a to condenser

Branch $b$ to condenser

6

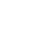

Recirculation Loop No. 2

\section{Main Line \\ Bypass \\ To Cleanup System \\ From Cleanup System}

\section{Cleanup}

Heat Exchanger 1 to Drywell

Recirculation Loop No. 3

Main Line

Bypass Line

Recirculation Loop No. 4

Main Line

Bypass Line

Recirculation Loop No. 5

Main Line

Bypass Line

Shutdown Cooling

From S. C. to R. L. No. 5

To S. C. from R. L. No. 5

Emergency Condenser Condensate

North Side (No. 2)

From Recirc. Loop 5

Branch a to condenser

Branch $b$ to condenser
MASS Joint

No.

Component Tabulation No.
$2-15 *$

$17-28$

$601-618$

$619-629$

$37,52-76$

$652-676$

$76-81$

$76,87-91$

677-681

687-691

102-115*

1001-1018

117-128

1019-1029

1030-1041

1302-1310

$642-646,301$

1297-1301

202-215*

701-716

217-228

717-727

302-315*

801-816

317-328

817-827

402-415*

901-920

$417-428$

921-931

439, 511-521

$932-942$

$437,451,501-509$

943-951

451-476

$952-976$

$476-481$

976-981

$476,487-491$

987-991

\footnotetext{
*See Figure 9
} 
straight tubing intersecting at a point (Figure 10). Reducers are modeled as a point change in piping or tubing size (Figure 11).

Instrumentation lines of 1 inch nominal diameter or less were not included in the MASS model because of their negligible effect on the stress calculation for large lines.

\subsection{BOUNDARY CONDITIONS}

The restraints and operating conditions of the piping were chosen to give conservative results for the piping stresses.

\subsubsection{Restraints}

The connections of the piping to the pressure vessel nozzles are all taken as rigid-no angular deflection about any axis-with the linear deflection of the nozzle determined from thermal expansion of the vessel under operating conditions. The pipelines are also assumed to be rigidly attached to the drywell near their isolation valves, with the vertical linear deflections of the drywell determined from its thermal expansion under operating conditions. These linear deflections of the drywell and pressure vessel are relative to the floor elevation at $\mathrm{x}=-441 \mathrm{in}$. and the centerline of the pressure vessel at $y=z=0$. The deflections were calculated using the coefficients of expansion given in Figure 12. The values for $\alpha \Delta \mathrm{T}$ for the pressure vessel and the skirt are taken from Reference 1 , using temperatures of $545^{\circ} \mathrm{F}$ and $350^{\circ} \mathrm{F}$, respectively. The temperature of the drywell and concrete vessel support was taken as $150^{\circ} \mathrm{F}$, and the skirt temperature was assumed to be the average of the pressure vessel and the drywell lemperatures. The value for $(\alpha \Delta T)_{3}$ for the support is from Reference 2. The drywell coefficient of expansion is from Reference 3.
The restraints due to pipe-supporting hangers are not considered in the nominal expansion stress analysis. The pipe weight is taken as zero in this calculation. The expansion stress is actually the change in stress due to the temperature change in the pipeline.

\subsubsection{Temperatures}

In the calculation of thermal expansion stresses, an attempt was made to use the temperature encountered during normal operation that would give the maximum nominal stress. Table 2 lists the operating temperature, the operating pressure, and its equivalent $\Delta T$ given by

$\Delta T=\frac{P R}{2 \alpha E t}\left[3-\frac{E}{G}\right]$,

and the temperature put into the MASS stress calculation.

For sub-model 1, the input temperature should require no explanation.

For sub-model 2, the core spray line was given a temperature approximately equal to the ambient temperature of the drywell. This line contains stagnant water during normal operation of the reactor. Water is circulated through it only during periods when the reactor is shut down. Therefore, the maximum temperature of this line should never be greater than 140 to $150^{\circ} \mathrm{F}$, except near the pressure vessel nozzle.

The feedwater line is assumed to have the temperature of the heated feedwater.

For sub-model 3, all control rod drive lines are assumed to be at reactor temperature. The 3-in. line from the pressure vessel to the control rod drive system is at reactor temperature and pressure during normal 


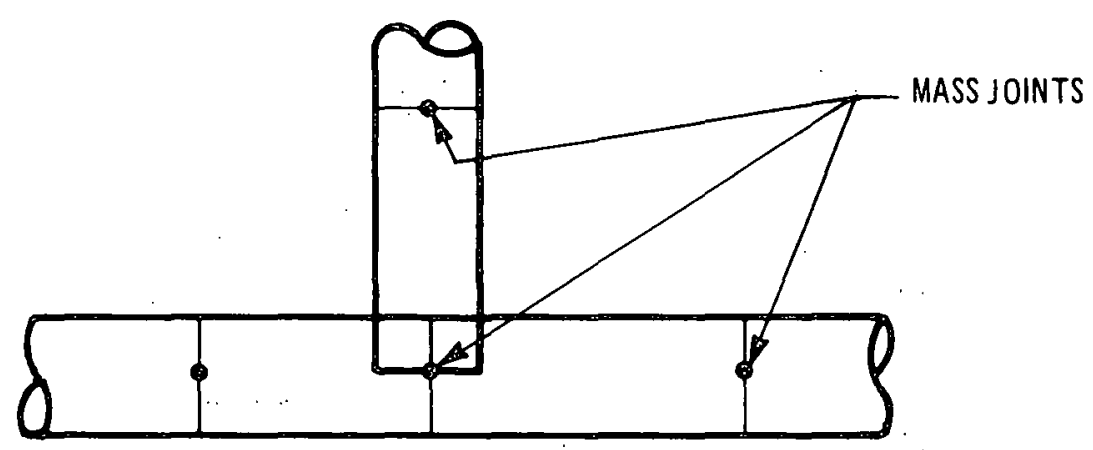

REDUCERS ARE MODELED AS A POINT CHANGE IN PIPING OR TUBING SIZE (FIGURE 11)

\section{FIGURE 10. MASS MODEL OF A PIPING TEE}

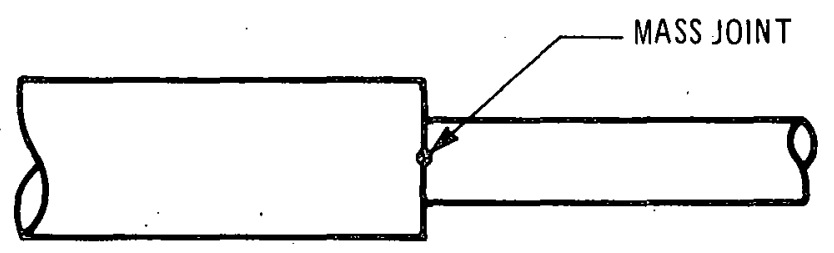

REDUCERS ARE MODELED AS A POINT CHANGE IN PIPING OR TUBING SIZE 


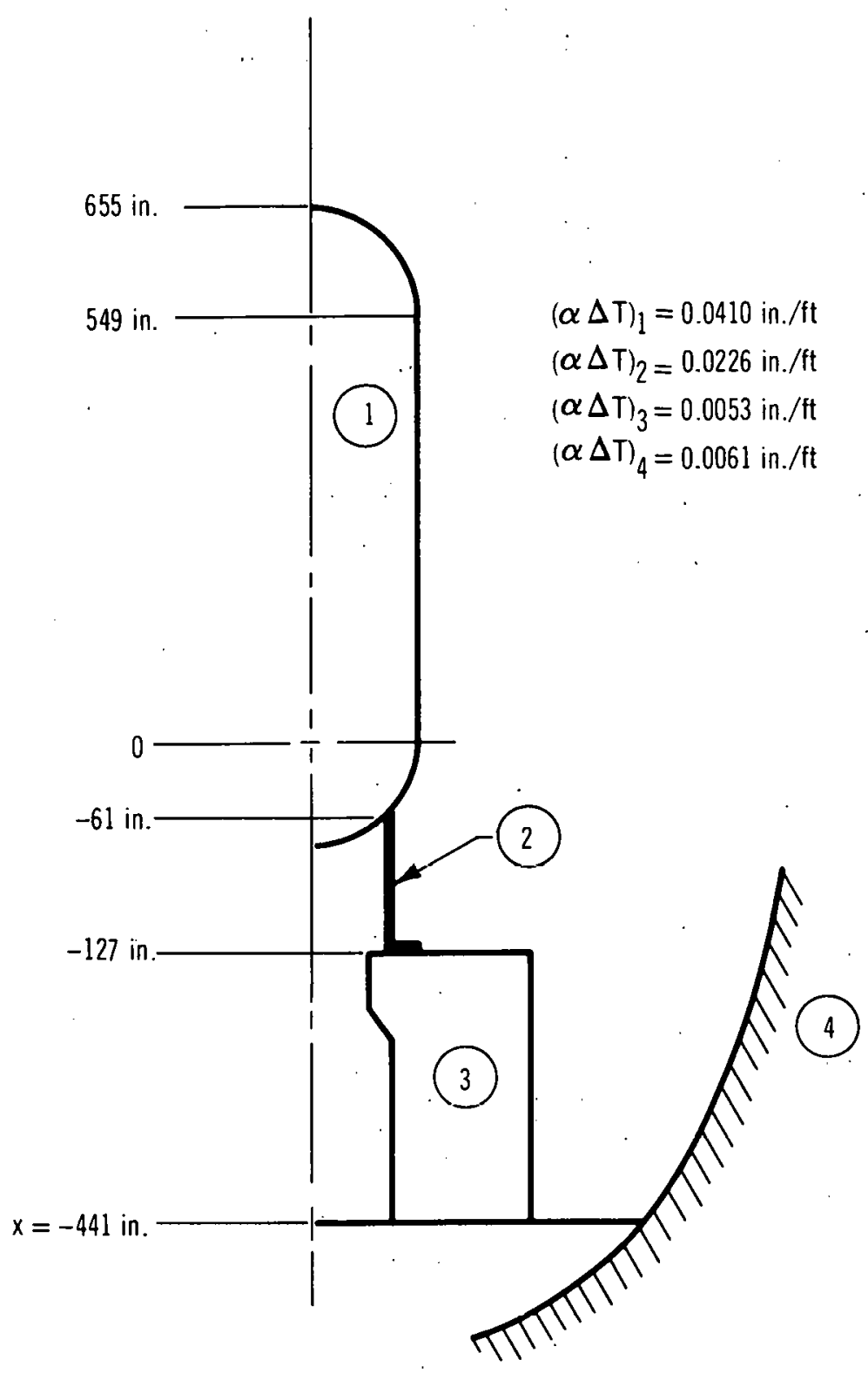

FIGURE 12. COEFFICIENTS OF EXPANSION 
TABLE 2

MASS INPUT TEMPERATURE

\begin{tabular}{|c|c|c|c|c|c|}
\hline $\begin{array}{l}\text { Sub-Model } \\
\text { No. }\end{array}$ & System & $\begin{array}{l}\text { Operating } \\
\text { Temperature }\end{array}$ & $\begin{array}{l}\text { Operating } \\
\text { Pressure } \\
\end{array}$ & $\begin{array}{c}\Delta \mathrm{T} \\
\text { Pressure }\end{array}$ & $\begin{array}{c}\text { MASS } \\
\text { Temperature }\end{array}$ \\
\hline \multirow[t]{4}{*}{1} & Primary System and Relief & 545 & 1000 & 10 & 555 \\
\hline & 4 in. Vent & 545 & 1000 & 7 & 552 \\
\hline & 2 in. Vent & 545 & 1000 & 6 & 551 \\
\hline & 2 in. Drain & 545 & 1000 & 6 & 551 \\
\hline \multirow[t]{2}{*}{2} & Core Spray & 140 & 1000 & 6 & 146 \\
\hline & Feedwater & 315 & 1260 & 10 & 325 \\
\hline \multirow[t]{3}{*}{3} & Control Rod Drive & & & & \\
\hline & All & - & - & - & 551 \\
\hline & Poison Spray & - & - & - & 551 \\
\hline 4 & Emergency Condenser Steam & 545 & 1000 & 7 & 552 \\
\hline $5,6,7,8$ & Recirculation Loop Nos. 1-5 & 545 & $\begin{array}{l}1015 / \\
1055\end{array}$ & 10 & 555 \\
\hline \multirow[t]{2}{*}{5 and 8} & $\begin{array}{l}\text { Emergency Condenser } \\
\text { Condensate }\end{array}$ & 150 & 1000 & 7 & 157 \\
\hline & Shutdown Cooling & 140 & 1000 & 6 & 146 \\
\hline \multirow[t]{4}{*}{6} & Cleanup & & & & \\
\hline & $\begin{array}{l}\text { To Heat Exchanger No. } 1 \\
\text { from Recirculation Loop } \\
\text { No. } 2\end{array}$ & 545 & 1000 & 6 & 551 \\
\hline & From Recirculation Pumps & 140 & 1015 & 6 & 146 \\
\hline & $\begin{array}{l}\text { From Heat Exchanger No. } 1 \\
\text { to Recirculation Loop No. } 2\end{array}$ & 436 & 1015 & 6 & 442 \\
\hline
\end{tabular}

operation. The lines to and from the control rod drive thimble will see reactor temperature and pressure due to leakage through the drive during an extended scram.

The poison spray line was assumed to be at reactor temperature and pressure. This is a conservative assumption because the part of the line near the pressure vessel nozzle is the only section that would see reactor temperature and pressure during normal operation.

The temperature assumed for the emergency condenser steam lines and the recirculation loops should require no explanation.

The emergency condenser condensate lines see only water that has gone through the emergency condensers. Even though this line contains stagnant water during normal operation, its temperature will not be greater than $150^{\circ} \mathrm{F}$ except near the tie-in to the recirculation lines. This is a local thermal discontinuity that should be investigated more thoroughly.

The previous discussion for the emergency condenser condensate also applies to the shutdown cooling lines inside the drywell.

The cleanup system has a variety of temperatures and pressures, but they are fairly straightforward and require little explanation. The temperature drops and increases through the heat exchangers were divided so that the $\Delta \mathrm{T}$ 's for each pass through the exchangers were equal. 


\subsection{MASS FLEXIBILITY ANALYSIS}

The MASS program achieves its results by first calculating the load-deflection relationships (the stiffness matrix) for each two-ended member in the structure, and then calculating the displacements at each joint which will result in the equilibrium of forces and moments at that joint. There are six displacements at each joint (three translational components and three rotational components). At each end of a structural member there are three forces and three moments which can be resolved into the following components:
1 axial force

2 transverse forces

1 torsional moment

2 bending moments

The stress calculation outlined in Appendix A considers only the bending and torsional moments. Stresses due to axial and transverse forces are generally negligible in piping systems.

In calculating the stiffness matrix for a structural member (piping component), the MASS program considers bending, shear, axial, and torsional deformations. The program also considers the increased bending flexibility of an elbow due to its cross section deforming to an oval shape.

SECTION III

\section{TABULATION OF COMPONENTS AND DISCONTINUITIES}

\subsection{COMPONENTS}

For the tabulation in Appendix B, components are defined as any discrete part of the piping.

\subsubsection{Component Types}

The components are of five types, as discussed below. A number that identifies the component type in the tabulation is also given.

a. Straight-component type 1-includes all straight sections of pipe. The length of the straight is established by discontinuities in the piping or a transition from a straight to a bend.

b. Elbow-component type 2-includes all curved sections that are to be welded into the line.

c. Bend-component type 3-includes all curved sections that have a large value for the ratio of radius of curvature to nominal diameter. These are assumed to be bend portions of a continuous pipe and are not actually a distinct component. It is tabulated separately for convenience in later reference to these sections of the piping.

d. Valves-component type 4-includes all valves in the system that have been modeled, as discussed earlier.

e. Equipment-component type 5-includes all pumps and heat exchangers.

\subsubsection{Cumponent Numbering}

The range of component numbers for each sub-model and piping system is given in Table 1. This table and Figures 1 through 9 can be used to locate any component in the tabulation of Appendix B. 
The numbering is not entirely systematic because of the complexity of the primary piping. It was attempted to number the components consecutively in each line, starting at the pressure vessel. However, some lines such as the emergency condenser condensate are not directly attached to the pressure vessel, and others are connected at more than one location (recirculation loops). Branch lines also complicate the component numbering. For cases in which the piping makes a complete loop, the numbering of components increases in the direction of normal flow. For lines in which only a section of the loop was included, the numbering increases in the direction going away from the pressure vessel. Branch line numbering was done as conveniently as possible.

\subsubsection{Component Properties}

For any further investigation of component flexibility, it is necessary to know the properties of the component. These are tabulated in Appendix B as they were put into the MASS flexibility model.

$$
\begin{array}{ll}
\text { 3.1.3.1 } & \text { Geometry } \\
\text { D } & \text { - } \text { outside diameter of pipe } \\
D^{*} & - \text { nominal diameter of pipe } \\
t & - \text { thickness of pipe } \\
\rho & - \text { radius of curvature of } \\
\theta & \text { - ibows and bends } \\
\text { included angle of elbows } & \text { and bends } \\
l & - \text { length of straight pipe sections }
\end{array}
$$

recirculation lines which are Type 316 . All piping with nominal diameter greater than $12 \mathrm{in}$. is assumed to be fusion welded, and all smaller piping is taken as seamless, according to Reference 4.

\subsection{DISCONTINUITIES}

Discontinuities are defined as a part of the piping or an attachment to the piping which may cause a stress concentration.

\subsubsection{Discontinuity Types}

In the "Type" column of the tabulation in Appendix B, the discontinuities are denoted by the letter " $\mathrm{D}$ " and a discontinuity type number.

a. Welds-discontinuity types 1 and $1 a-$ are assumed to be one of two types in the primary piping according to Reference 4.

1. Butt welds-denoted by D-1are used in all piping greater than 2 in. nominal diameter.

2. Socket welds-denoted by D-1aare used for all piping equal to or less than 2 in. All valves in the primary system are assumed to be welded into the piping.

b. Hangers-discontinuity type 2-are included as discontinuities because they exert a concentrated load on the piping. The exact hanger locations were not available for most of the piping. An approximation to their location was obtained by using the table on page 2 of Reference 1 , and repeated on page 85 of Reference 3 . This table gives the maximum allowable unsupported span for various pipe sizes. The hangers are 
conveniently placed at MASS joint locations so that later work in which hanger influences will be investigated can be conducted without additional joints.

c. Instrumentation-discontinuity types 3 and $3 \mathrm{a}$-has been located approximately from information in the piping and instrumentation diagrams.

1. Instrumentation line tapsdenoted by D-3-are connections of 1-in. lines or smaller which have not been included in the MASS flexibility analysis.

2. Flowmeters-denoted by D-3aare also overlooked in the MASS analysis because of their geometry (see Figure 13).

d. Branch line connections-discontinuity type 4-are points where two lines, both greater than 1 in., meet. Tees and wyes are included in this category for ease of tabulation. The tee can be thought of as being constructed from three straight components-two run components and one branch componentas shown in Figure 10. Wyes are treatcd in the same manner.

e. Flanges-discontinuity type 5-are found only in the recirculation loops on decontamination nozzles. f. Reducers-discontinuity type 6-are tabulated as discontinuties because of the modeling discussed earlier (see Figure 11).

\section{3 ALLOWABLE STRESSES}

The allowable expansion stress for piping was calculated from

$S_{A}=f\left(1.25 S_{C}+0.25 S_{H}\right)$,

given in the ASA B31. 1 piping code, ${ }^{(3)}$ where $f$ is a function of the number of cycles and is equal to 1.0 for less than 7000 cycles. $S_{C}$ and $S_{H}$ are the cold and hot allowable stress for the piping material. For this tabulation, the values for $S_{C}$ and $S_{H}$ were taken from the ASME Boiler and Pressure Vessel Code, Section VIII, including the June 1965 addendum. $S_{H}$ was based on the tabulated temperature, which includes the $\Delta T$, to account for longitudinal expansion due to pressure as discussed previously. The same allowable stress was used for welded and seamless, because the welded pipe in the primary system is required to be fully radiographed.

The sum of the longitudinal stresses due to pressure, weight, and other sustained external loading is limited to an allowable stress of $\mathrm{S}_{\mathrm{H}}$.

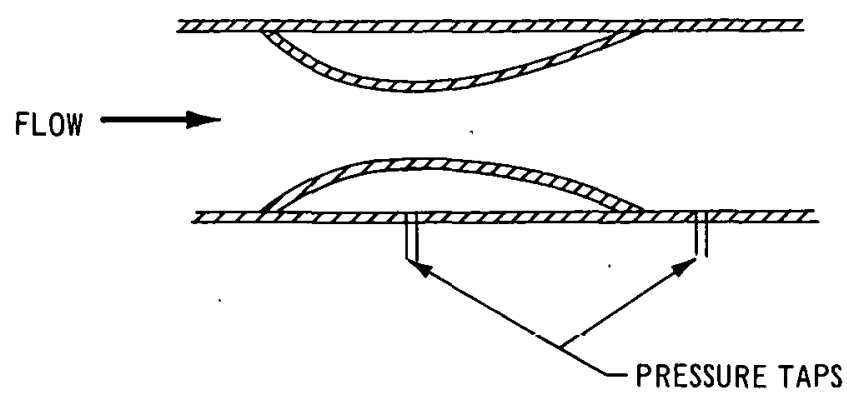

FIGURE 13. FLOWMETER 


\section{4 NUMBER OF CYCLES}

The number of significant thermal cycles which each system would see during the 40-year expected life of the reactor is based on an estimation of reactor operating procedures during its lifetime. It is important for future investigation, even though it does not affect $S_{A}$ when less than 7000 .

For the reactor primary steam lines and the vent pipe, the number of thermal cycles from ambient to operating temperature in 40 years is given as 360 . This number includes 200 scrams and 160 normal startups and shutdowns.

The recirculation loops would go through a thermal cycle from ambient to operating during a scram or shutdown, so the number of cycles is taken as 360 for them also. The same number was used for the shutdown system at the tie-in to the recirculation loop.

The emergency condenser and cleanup systems were assumed to see the 360 cycles in reactor temperature and pressure, plus an additional 140 cycles. The additional 140 for the emergency condenser is a conservative number for the expected times it will be used. The additional 140 for the cleanup is the number of times parts of the cleanup system may be bypassed for repair, changing of filters, etc.

Because there is a possibility that the drain line from the reactor may be tied into the cleanup line, it was assumed to see the 500 cycles of the cleanup system. The feedwater sees the effect of the 360 cycles in reactor temperature and pressure, plus an additional 80 cycles due to expected loss of heaters, giving a total of 440 cycles. The core spray and poison spray systems also see the cycling of the reactor plus an additional 10 cycles resulting from emergency conditions, giving a total of 370 cycles.

The 3-in. line from the pressure vessel to the control rod drive system sees the 360 cycles of the reactor. However, the lines from the control rod drive system to the control rod drive thimbles are maintained at a relatively low constant temperature, except during an extended scram. Then reactor water leaks through the drives into the line. Therefore, the number of cycles for the hydraulic lines is conservatively taken as the number of scrams expected, or 200 .

SECTION IV

\section{STRESS CALCULATIONS AND RESULTS}

\section{1 THERMAL EXPANSION STRESS}

The tabulated stress $S_{E}$ is the thermal expansion stress as calculated with the MASS model discussed in Section II and in Appendix A. The MASS calculation applied a stress intensification factor at elbows, as required for the code calculation for $S_{E}$. It does not apply the factor to tees and socket welds, however, so separate calculations for these components were made as described below.

According to Reference 4, welding tees are used when the branch line is greater 
than 2 in. or the branch line is greater than one-fourth of the diameter of the run. All .. branch lines or tees in the primary system are welding tees according to this criteria.

The stress intensification factor i for welding tees is calculated by Section 6 of the ASA B31. 1 Code by

$i=\frac{0.9}{\left(8.8 \frac{t}{D}\right)^{2 / 3}}$.

This factor was applied to the stress at the MASS joint connecting the branch and two run components. The stresses for each of the intersecting components were taken as the maximum of the stresses at their end joints with the stress intensification applied.

Socket welds were assumcd for all piping of 2-in. diameter or less. The stress intensification factor for singlewelded socket weld flanges is given by the ASA Code as 1.3. This was applied to the stresses at all socket welds.

Table 3 gives the number of different components and discontinuities in the primary piping.

TABLE 3

SUMMARY OF THE NUMBER OF COMPONENTS AND DISCONTINUITIES

\section{Components}

Straights
Elbows
Bends
Valves
\[ \text { Discontinuities } \]

Tees and Branches $>1$ in. 430 180

80 80
The distribution of the ratio of expansion stresses to allowable stresses for all the straights, elbows, and bends is given in Figures 14 and 15. It should be noted that the only component that had a value of $\mathrm{iS}_{\mathrm{E}} / \mathrm{S}_{\mathrm{A}}$ greater than 0.7 was the straight component number 226 in the core spray line. It had a value of 1.004 , and should be investigated further. An additional allowable stress can be obtained by establishing that the longitudinal stresses are low compared to the hot allowable stress.

When observing these results, it should be remembered that this is only one part of the check of system stresses with the allowable stresses required by the piping code. Another separate comparison of the hoop stresses due to pressure with the allowable stresses is required. Some examples of this comparison are given in Table 4 , and for the purposes of this summary it can be assumed that the remaining systems.would have similar values.

A histogram of the cross-sectional flow areas of the individual components normalized by the cross-sectional flow area of the 26 -in. recirculation lines is shown in Figures 16 and 17 . This information should be useful in a statistical determination of the consequences of the complete severance of a pipe.

\subsection{WEIGHT STRESS}

The stresses in the primary piping which result from weight effects exert a small, although important, influence on the total stress in the piping system. The weights included in this analysis were those of the pipe, fluid, and insulation.

The piping is supported by a number of pipe hangers which have been judiciously located throughout the system in a manner intended to minimize the gravity-induced 


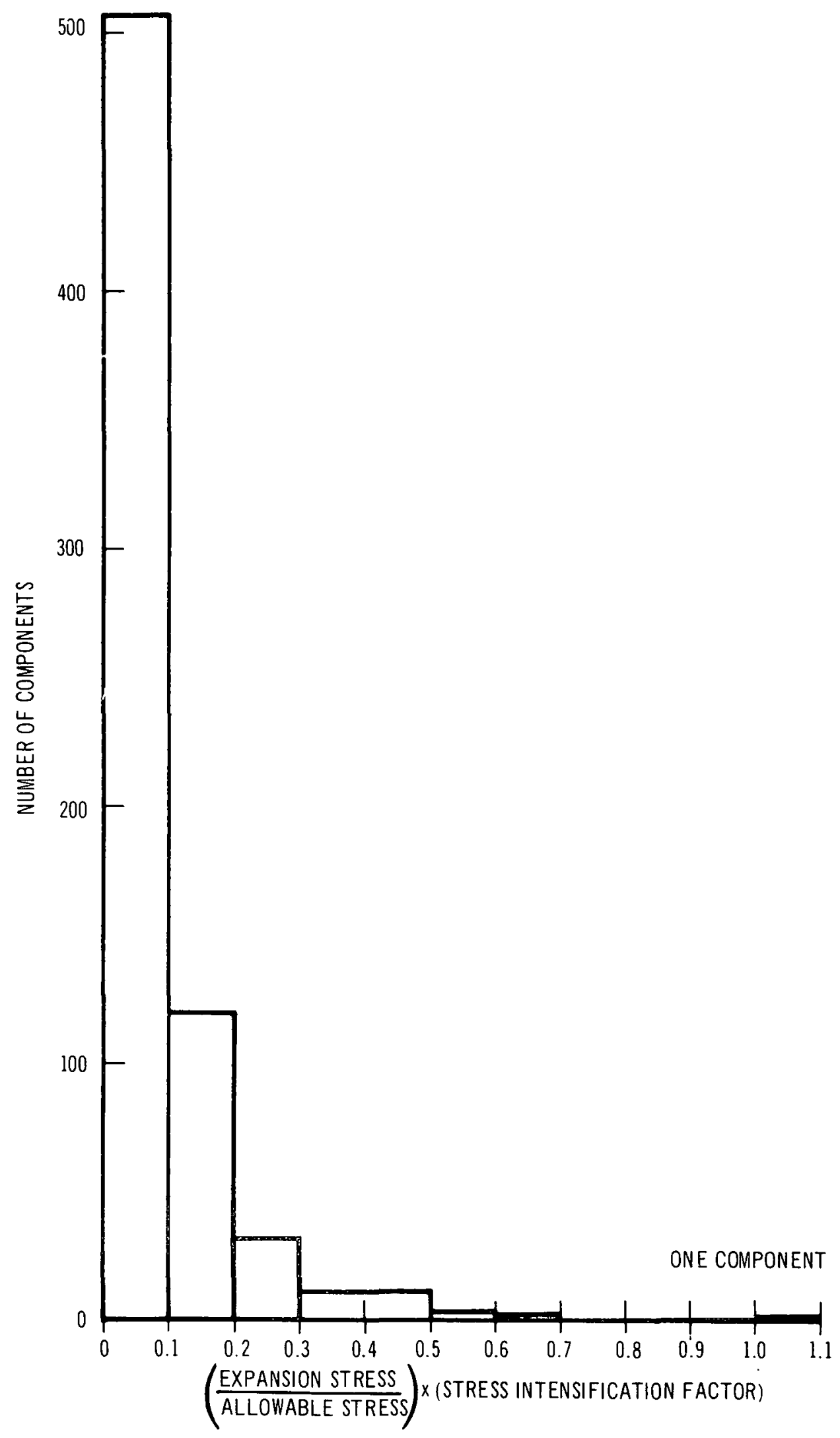

FIGURE 14. DISTRIBUTION OF COMPONENT STRESSES 


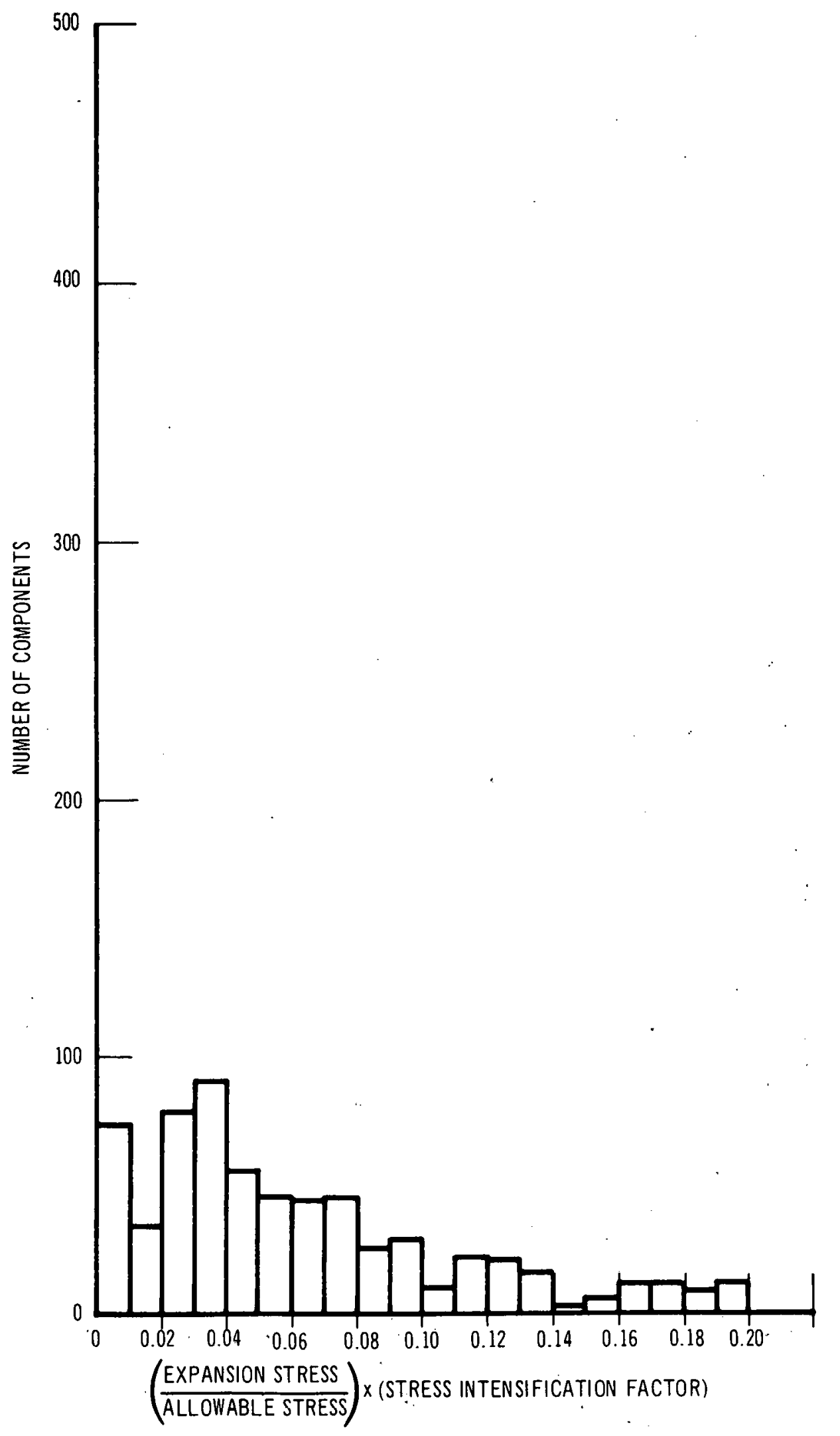

FIGURE 15. DISTRIBUTION OF COMPONENT STRESSES 


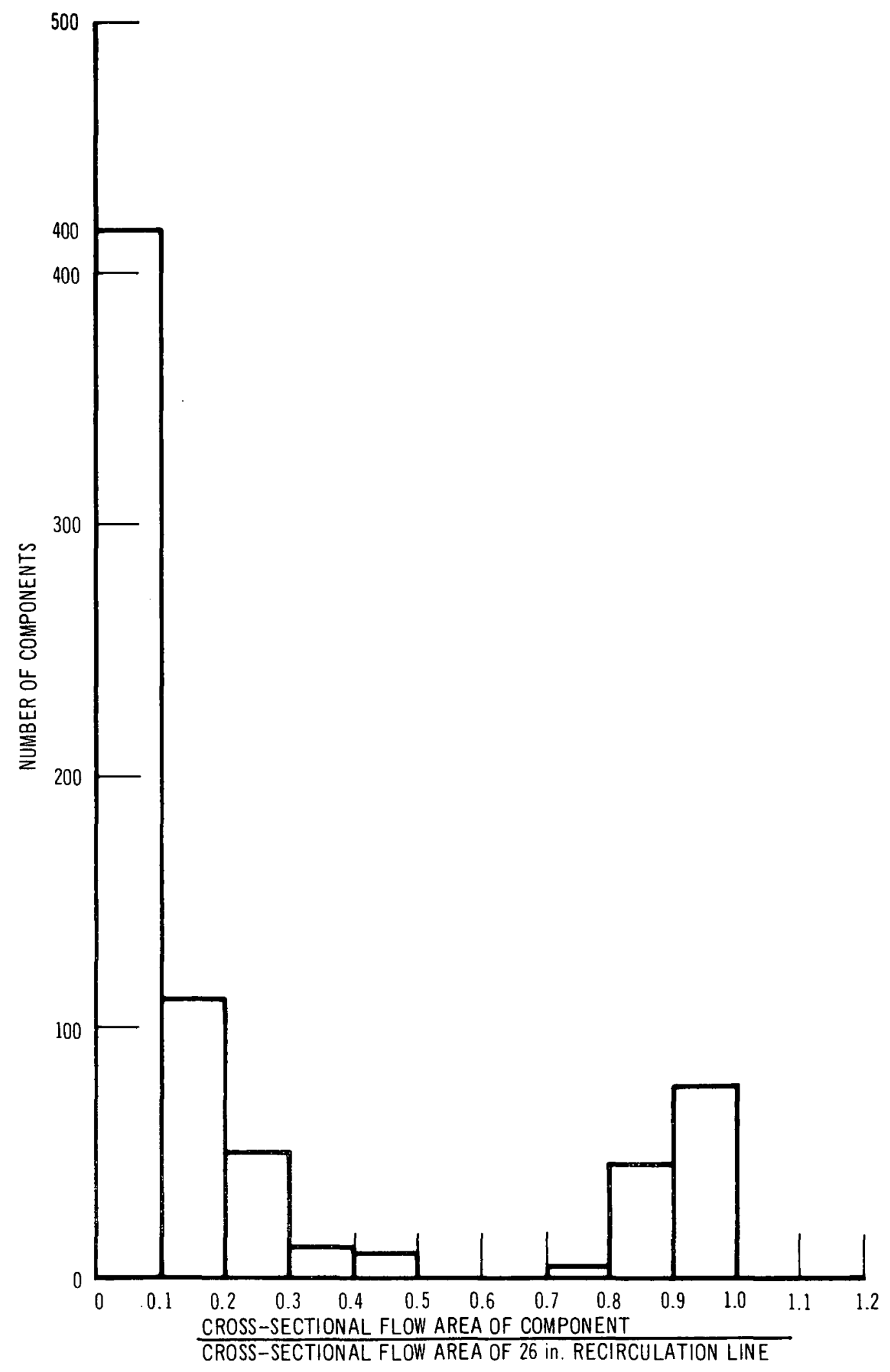

FIGURE 16. DISTRIBUTION OF CROSS-SECTIONAL FLOW AREAS 


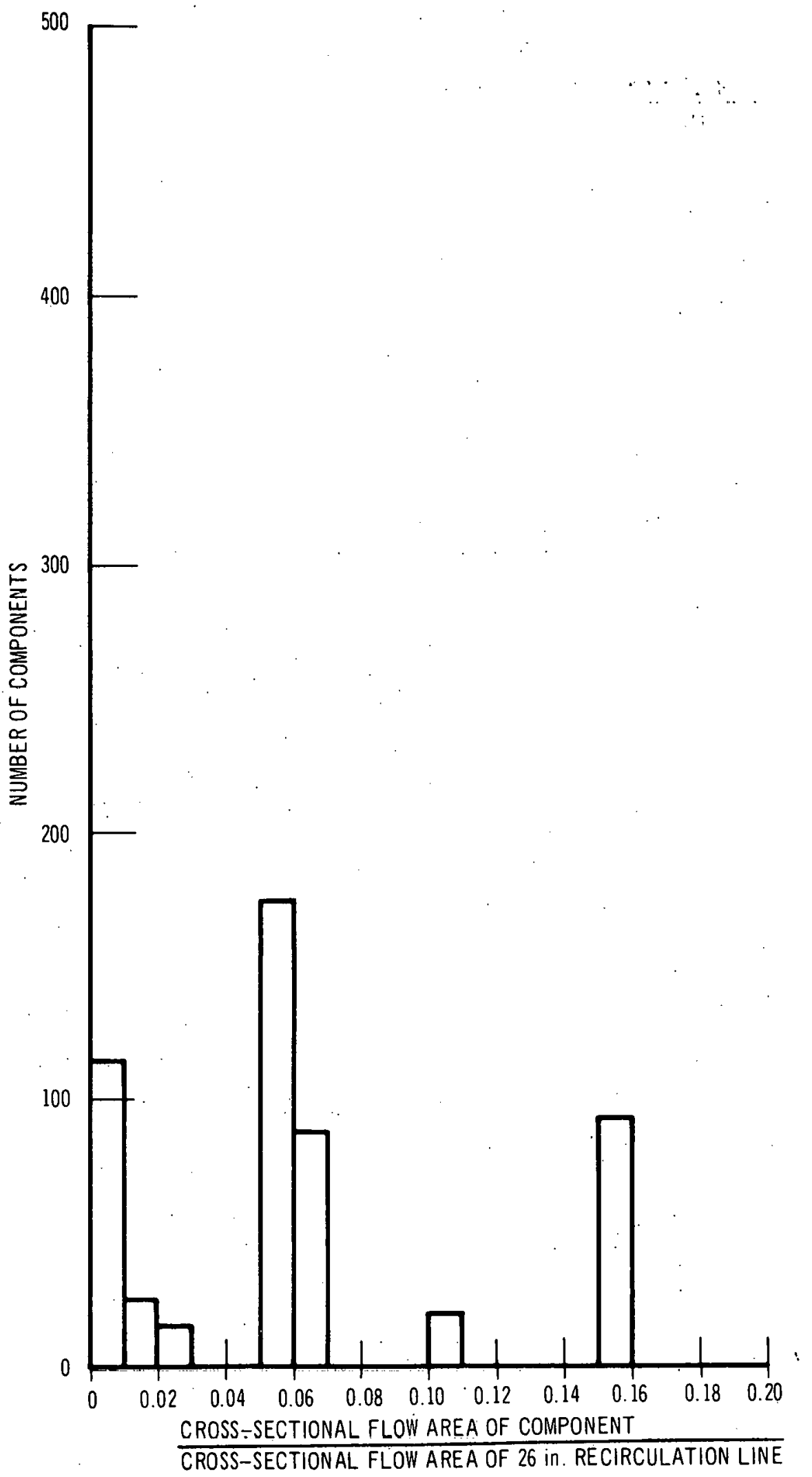

FIGURE 17. DISTRIBUTION OF CROSS-SECTIONAL FLOW AREAS 
TABLE 4

COMPARISON OF TYPICAL HOOP PRESSURE STRESSES WITH THE ALLOWABLE STRESS

\begin{tabular}{|c|c|c|}
\hline System & $\mathrm{S}_{\mathrm{p}}=\frac{\mathrm{Pr}}{\mathrm{t}}$ & $\mathrm{S}_{\mathrm{H}}{ }^{*}$ \\
\hline \multicolumn{3}{|l|}{ Primary Steam } \\
\hline 24 in. $-A-106 C$ & 9,852 & 17,500 \\
\hline \multicolumn{3}{|l|}{ Core Spray } \\
\hline 6 in. -304 & 7,667 & 16,000 \\
\hline \multicolumn{3}{|l|}{ Recirculation } \\
\hline 26 in. -316 & 13,437 & 16,000 \\
\hline
\end{tabular}

${ }^{*} \mathrm{~S}_{\mathrm{H}}$ is the allowable stress at operating conditions.

stress in the piping for the number of hangers chosen. As stated previously, provision for pipe hangers was made while selecting joint locations for the flexibility analysis. The location chosen for the hangers followed the guidelines suggested in Reference 1. To reduce the stress resulting from weight loading, the hangers may be moved to more favorable locations, or additional hangers may be added. In fact, weight stress can be reduced to an almost negligible value by the addition of more and more hangers. This is obviously not economically feasible, nor is it necessary, since weight stresses are generally small when the guidelines given in Reference 1 are followed.

The weight stresses in a typical BWR were calculated using the MASS computer program and the same BWR piping model that was used in the thermal expansion stress analysis. It was determined that a conservative approximation of weight stress could be obtained by lumping distributed pipe weights (including the weight of fluid and insulation) into concentrated forces at the joints of the MASS computer model. This greatly simplifies the input for MASS because concentrated forces at joints can be input as a boundary condition force acting in the vertical direction. On the other hand, the use of distributed weights in the MASS program, which is the more accurate procedure, requires considerable geometric manipulation to account for pipe orientations relative to both vertical and horizontal planes, and to account for pipe bends and elbows.

The closer the joints are spaced between supports, the more closely the concentrated force model approximates the distributed load case. It can be shown with a simple beam model that the conservatism in calculated stress associated with the concentrated force analogy approaches a factor of safety of 2 when a distributed load is replaced by a single concentrated load located midway between the supports.

To simplify the analysis further, it was assumed that at each hanger location there was zero vertical deflection as a result of pipe weight. For a given zero deflection at a hanger; the MASS computer program calculates the hanger load necessary to produce such restraint. This load can then be provided by either a constant or or a variable support hanger. By selecting 
a variable support hanger with as soft a spring as permitted by Reference 1, the change in hanger load can be minimized as the system goes from cold to hot. If the load change exceeds $25 \%$ when using a variable support hanger, it is recommended in Reference 1 that a constant support hanger be used.

A slight additional conservatism results from the use of a constant water density of $62.5 \mathrm{lb} / \mathrm{ft}^{3}$ even though at operating pressure and temperature the density is generally less than this value. The weight of steam contained in the steam lines was neglected. All insulation was assumed to be Unibestos, which has a density of about $16 \mathrm{lb} / \mathrm{ft}^{3}$. Necessary insulation thicknesses were approximated using tables in Reference 1 which relate pipe size, temperature, and insulation thickness. Where possible, the weight of valves was obtained from APED or vendor drawings. In other instances, the valve weight was obtained from tables which are also included in Reference 1. These tables give valve weight as a function of valve type (gate, globe, etc.), size, and pressure rating. In every instance where it became necessary to use these tables, the heaviest valve listed for a given size and pressure rating was chosen to ensure conservatism.

The weight-induced stresses calculated using the techniques and assumptions just described are tabulated in the column entitled "S $\mathrm{W}_{\mathrm{W}}$, Weight" in the table of stresses. In no case does the combination of longitudinal bending stress resulting from weight and longitudinal stress resulting from pressure exceed the allowable design stress for the material and temperature at the point under scrutiny. In some cases, where the combined longitudinal stress did slightly exceed the allowable, it was decided that rather than relocate existing hangers or add additional hangers to reduce the stress and then perform another iteration of stress analysis, all the stresses in the affected portion of the sub-model would be scaled down so that the maximum combined stress would just equal the code allowable. The distribution of stresses should remain relatively unaffected and, therefore, have only a very small influence on the reliability study.

\subsection{EARTHQUAKE STRESS}

The stresses in the primary piping that result from earthquake forces are also calculated using the technique of concentrated loads at the joints of the MASS model. The forces are applied in two orthogonal directions (e.g., N-S then E-W), and the stresses are calculated for each loading direction. Generally, when using this method for determining earthquake stresses, the horizontal "g" loading must be established for the particular site location that has been chosen. Therefore, in order to determine reasonable earthquake design criteria for a typical BWR, a site location must be chosen for the plant and seismic information gathered which apply to that site. To keep this study relatively general, it was assumed that the site was located in the Middle Atlantic states at some point approximately equidistant from the regions of the large earthquakes of Charleston, S. C. (August 31, 1886) and Quebec, Canada (February 28, 1925). This was considered to be a typical plant location, even though the earthquakes described were accompanied by less intense ground shaking than that accompanying the several major California earthquakes.

The historic seismicity of that section of the United States is described in the U.S. Coast and Geodetic Survey publication, "Earthquake History of the United States: Part I. "(5) A plot of earthquake epicenters given in this publication is shown in Figure 18. A list of earthquakes for the Eastern U. S., covering the period from 1663 


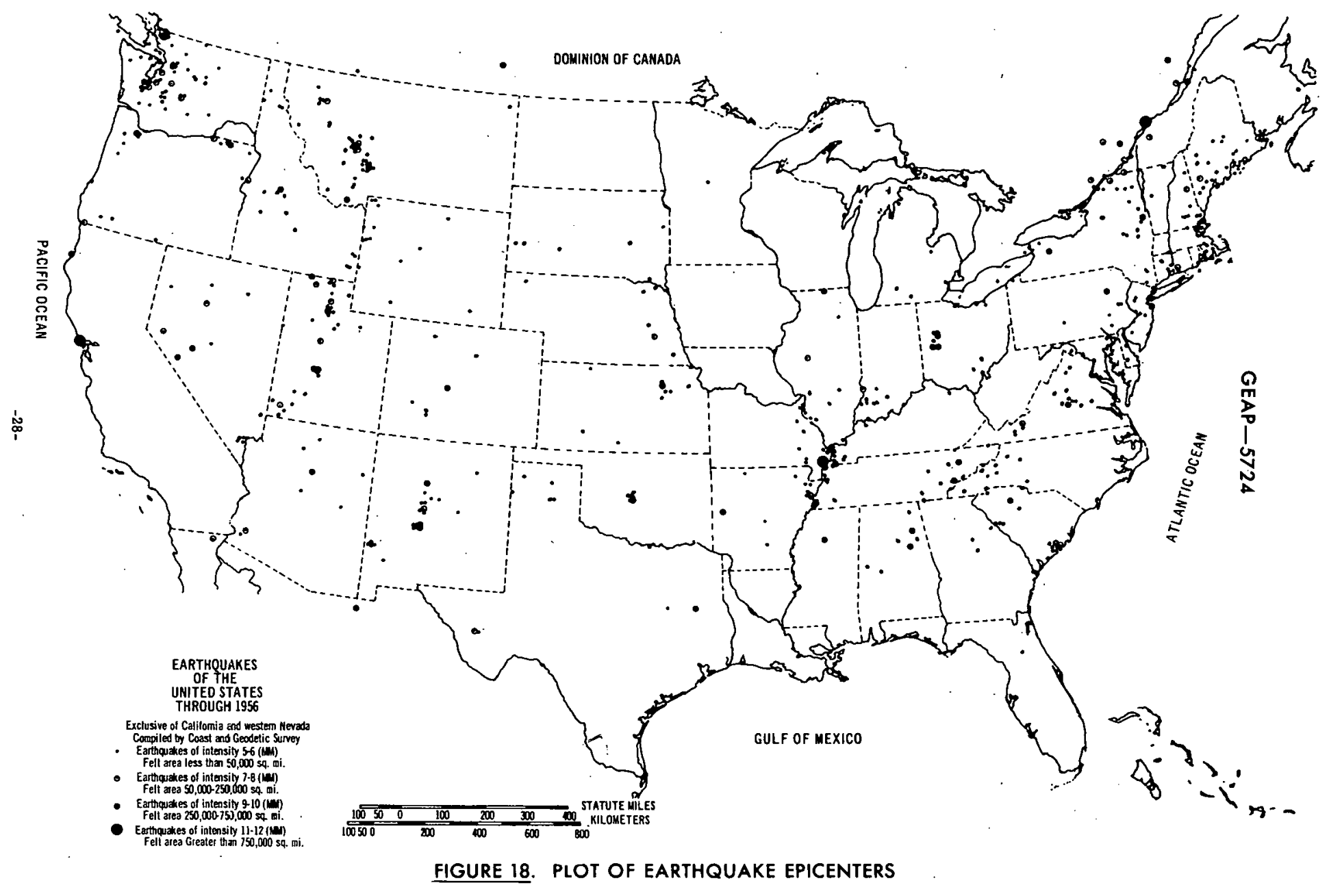


to 1956 , is given in Reference 5 . The seismic probability map (Figure 19) shows the Middle Atlantic area as Zone 1, with the earthquake zones having the following classifications:

Zone 0 - No damage

Zone 1 - Minor damage

Zone 2 - Moderate damage

Zone 3 - Major damage

It is assumed that the site would not be located in the vicinity of a known earth fault. Therefore, the probability of fault displacements occurring in the vicinity of the reactor structure is assumed to be negligible.

The estimated maximum intensity of ground shaking to be anticipated at a site located in the Middle Atlantic states (Zone 1) should be based upon the largest close earthquake. A method suitable for obtaining an approximation of this intensity of shaking is to use the seismic probability map shown in Figure 19. For example, if, as expained in Reference 6, it is assumed that the spectrum intensity for California (El Centro) Zone 3 is $\mathrm{I}_{0.2}=2.7$. then the spectrum intensities corresponding to the other zones are:

$$
\begin{aligned}
& \text { Zone } 3-\frac{\mathrm{I}_{0.2}}{2.70} \\
& \text { Zone 2 }-1.35 \\
& \text { Zone 1 }-0.67 \\
& \text { Zone } 0-0.33
\end{aligned}
$$

where $\mathrm{I}_{0.2}$ is the spectrum intensity for $20 \%$ damping. a measure of the intensity of ground motion. Because of the importance of a reactor site and the limited seismic data available, it is common to assume an uncertainty or safety factor. For this case, a factor of 1.40 has been chosen which yields a probable maximum intensity of $I_{0.2}=0.67 \times 1.40=0.94$ expected at the site Zone 1 during the life of the plant.

The design of the BWR piping system to withstand earthquake forces should be based on a dynamic analysis of the piping using the acceleration response spectrum. $\mathrm{S}_{\mathrm{a}}$ (Figure 20), or the velocity response spectrum, $S_{v}$ (Figure 21), where $S_{a}$ and $S_{v}$ are related by the equation

$S_{a}=\frac{2 \pi}{T} S_{v} \cdot T=$ natural period of vibration.

The spectra of Figures 20 and 21 correspond to a spectrum intensity $\mathrm{I}_{0.2}=0.94$ and can be obtained from Reference 7 as follows: Figures 7 and 8 of Reference 7 represent the Average Velocity and Average Acceleration Spectrum curves, respectively. for $\mathrm{I}_{0.2}=1.0$. These curves are multiplied by the design intensity factor for this plant, $\mathrm{I}_{0.2}=0.34$ to obtain the design spectra shown in Figures 20 and 21.

For structures (either buildings or equipment) whose failure might cause a nuclear incident, it will be assumed that the values of damping given in the following are appropriate for strong vibrations within the elastic limit:

\begin{tabular}{lc} 
& $\begin{array}{c}\text { Percent } \\
\text { Critical } \\
\text { Damping }\end{array}$ \\
\cline { 2 - 2 } Concrete reacior structure & 10.0 \\
$\begin{array}{l}\text { Reinforced concrete frame } \\
\text { structures }\end{array}$ & 5.0 \\
Steel frame structures & 2.5 \\
Bolted and riveted assemblies & 2.0 \\
Welded assemblies & 1.0 \\
Vital piping systems & 0.5
\end{tabular}

The natural periods of vibration of the buildings and equipment are also required for a complete dynamic analysis. However. in order to simplify calculations for this 


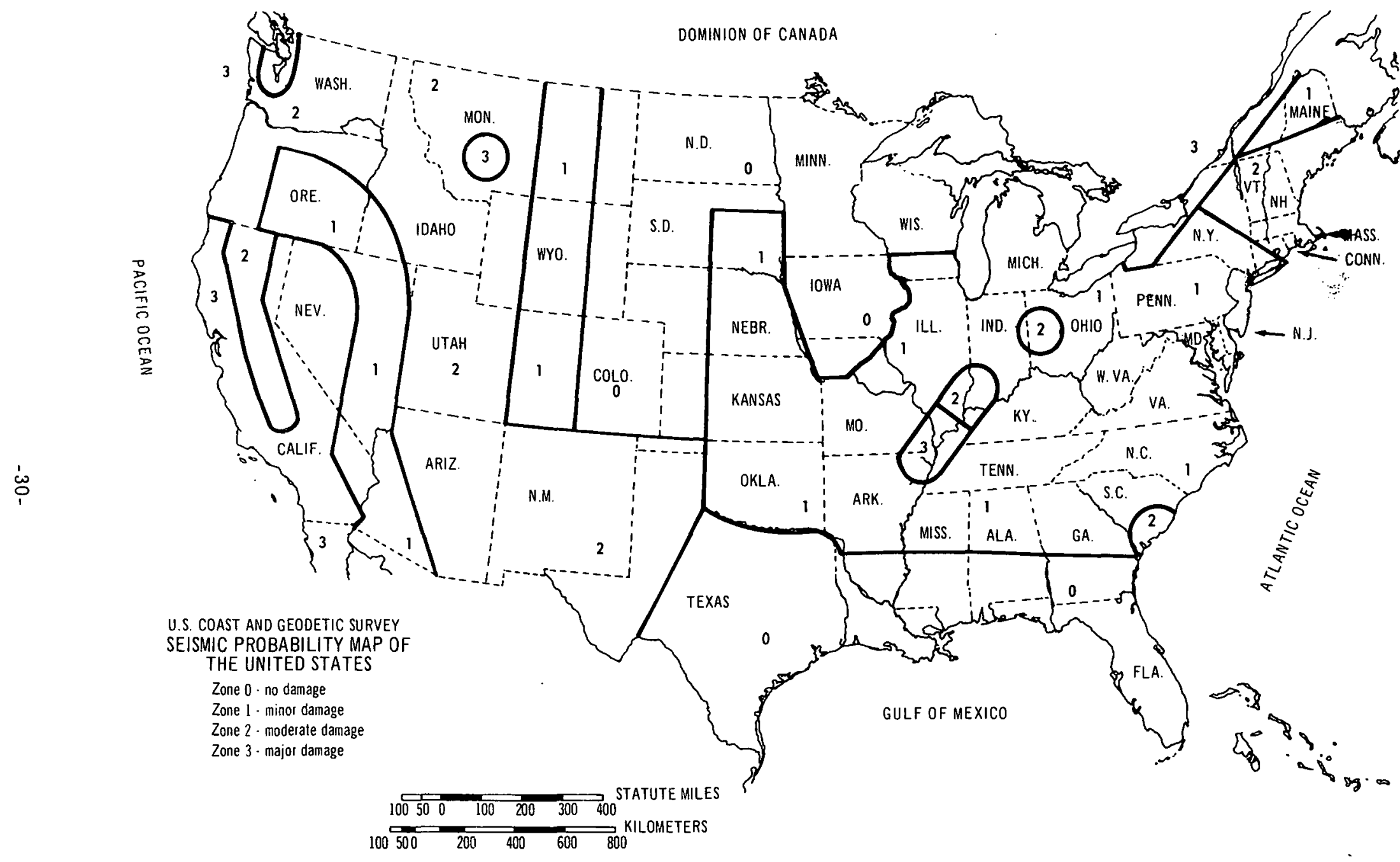

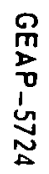




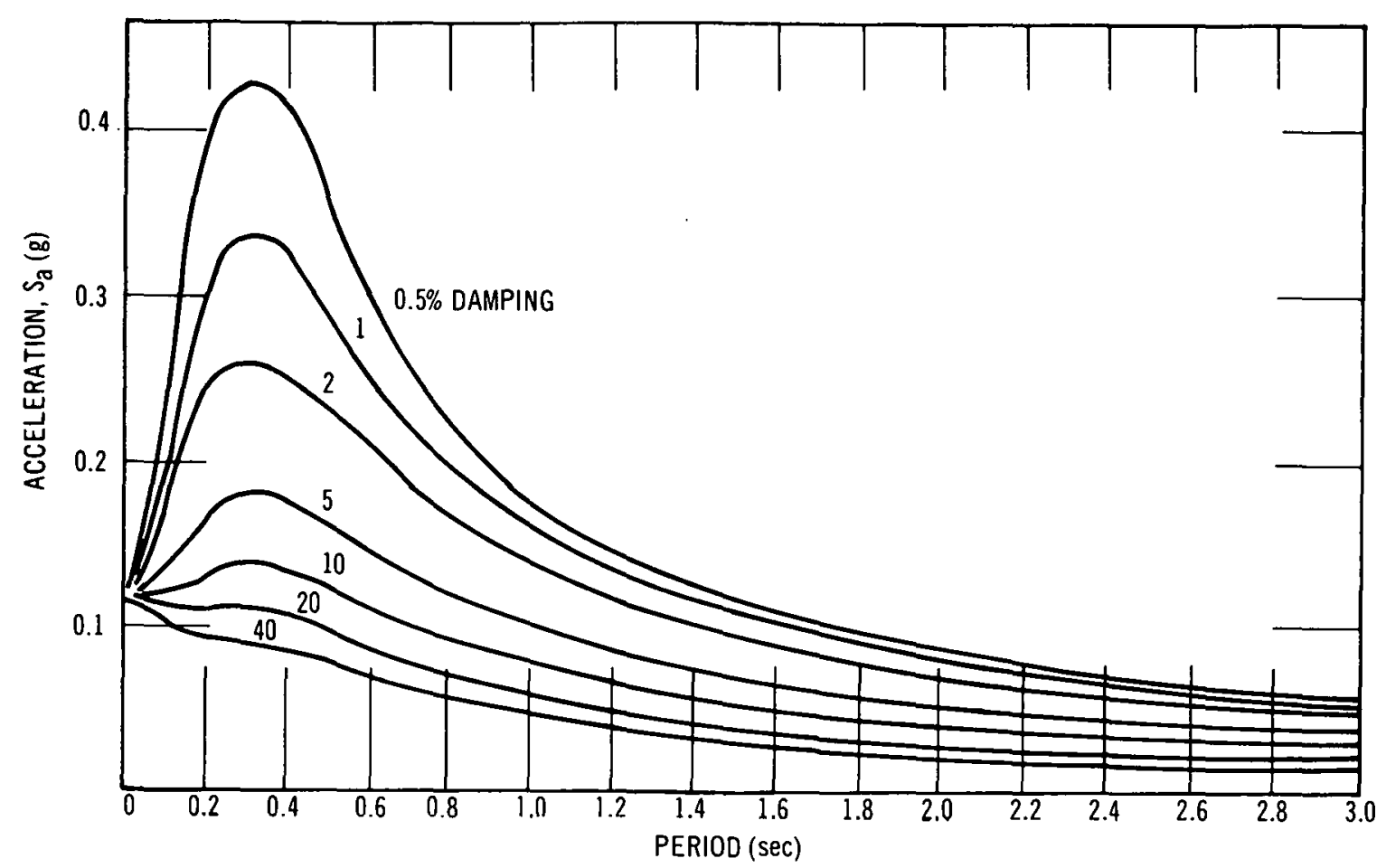

FIGURE 20. EARTHQUAKE ACCELERATION RESPONSE SPECTRUM

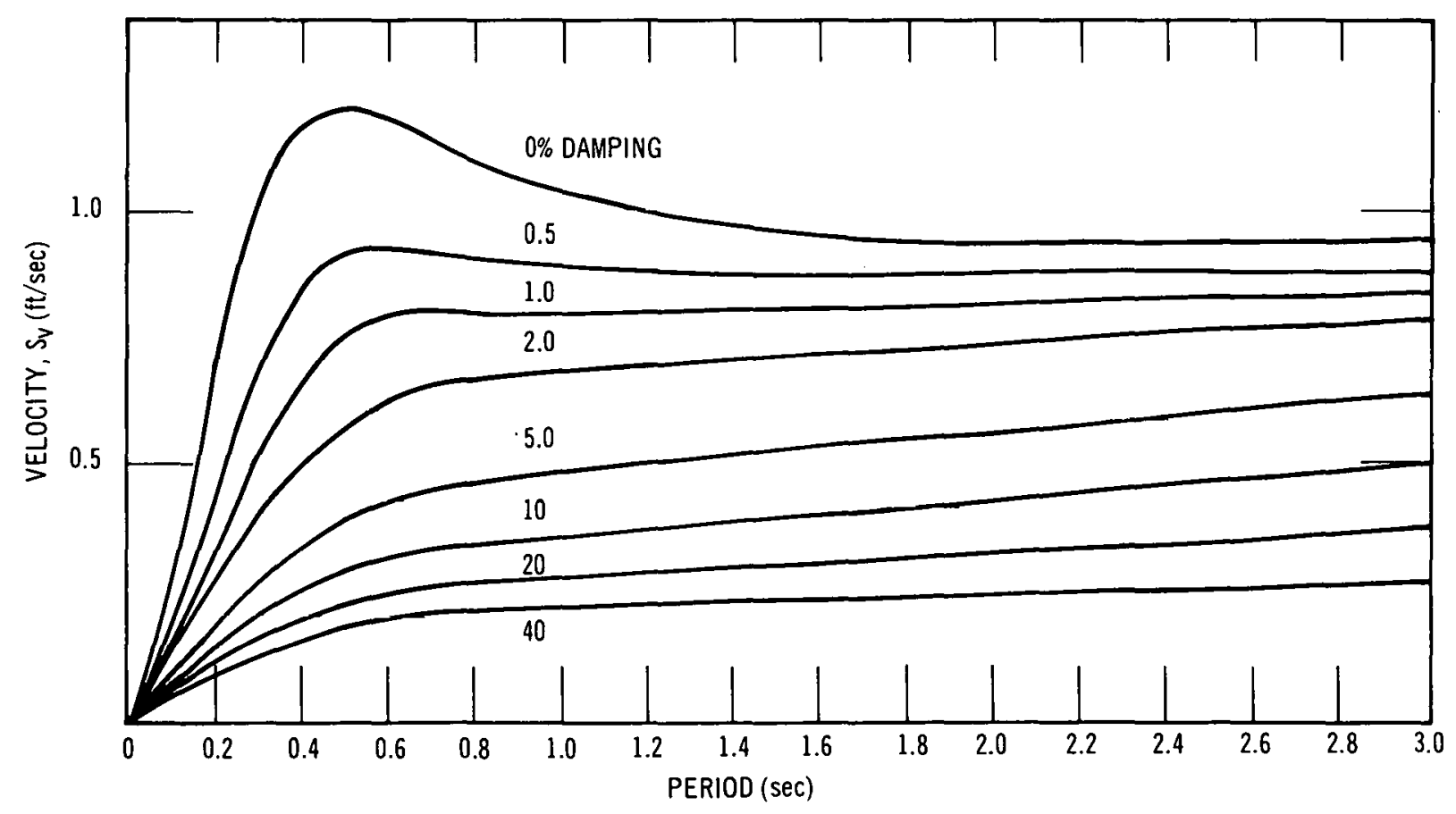

FIGURE 21. EARTHQUAKE VELOCITY RESPONSE SPECTRUM 
study, the maximum value of $\mathrm{S}_{\mathrm{a}}$ given by the spectrum in Figure 20 for the applicable value of damping ( $0.5 \%$ for piping) will be chosen. Hence, the horizontal earthquake forces for a typical BWR piping system were determined using $\mathrm{S}_{\mathrm{a}}=0.43 \mathrm{~g}$ (see Figure 20).

Where long vertical runs of piping were present, it was necessary to add sway braces to prevent excessive lateral movement of the piping during earthquakes. The suggestions given in Reference 1 for acceptable pipe span for use in locating hangers were used as a guide for the proper placement of sway braces. The sway braces selected were taken from a standard pipe hanger and support catalog, and were chosen in accordance with the manufacturer's recommendations.

In some cases where the combined longitudinal stress slightly exceeded the allowable, it was decided that rather than add or relocate hangers and sway braces and then perform another iteration of stress analysis, all the stresses in the affected portion of the submodel would be scaled down so that the maximum combined stress would just equal the code allowable. The distribution of stresses should remain relatively unaffected by the scaling and, therefore, have only a very small influence on the reliability study.

Many approximations have been made for the earthquake analysis, and undoubtedly some error is introduced with each approximation. As the techniques for calculating earthquake stresses are developed and refined, most of the approximations can be eliminated. Some areas of the analysis that require further refinement are:

a. Use of distributed rather than concentrated forces;

b. Consideration of a variable density of water with temperature; c. Method to determine the direction of the earthquake force vector that produces the maximum stress in the piping rather than using simple $\mathrm{N}$ - E-W force vectors;

d. Improvement of information available on the basic seismology of the area;

e. Determination of the force amplification from the ground to the attachments;

f. Determination of relative anchor point movements and the effects therefrom;

g. Consideration of large amplitude, variable damping;

h. Accuracy of the basic flexibility analysis, particularly in the vicinity of tees, elbows, laterals, etc. :

i. Determination of the effect of limit stops, where these may be present in a piping system; and

j. Comparison of results of singledegree versus multi-degree spectra as exciting forces.

\subsection{IMPACT STRESS}

The stresses that result from impact loading on piping must be considered by the piping designer during layout and design of the piping system. For this study, an impact loading will be defined as a sudden application of forces or motions to a pipe or component during a time interval less than or equal to the lowest natural period of vibration of the pipe or component.

In most instances, hydraulic impact is either absent or insignificant; however, on other occasions it can become a major 
cause of failure. The design procedures available to guard against an impact failure are idealized, and in many cases require experimental verification. Additional difficulty arises because the designer may not. in all instances, recognize the presence of a potentially hazardous design from the standpoint of impact loading. In other cases, where the seriousness of impact loading is recognized, both the design and operation of the system are coordinated to minimize or avoid any potential problem.

The primary area of concern in a BWR piping system is in the main steam line, where impact-type stresses can arise from two sources: (a) impact of a two-phase mixture with the quick-closing isolation valves in the steam line, and (b) the jet force reaction that results when safety and relief valves lift. In consideration of the first type of impact stress, an analysis ${ }^{(8)}$ was made of a steam line (24-in.) break outside the containment for a reactor pressure of 1000 psia. It was determined that a steam-water mixture slug could form in the steam line and slam into the isolation valves should a system malfunction cause a valve closure delay following the line break. Nozzle flow limiters installed in the steam lines and rapid isolation valve closure times tend to ensure continuous core coverage following a steam line break. The flow limiter considerably reduces blowdown, system decompression, and mixture level rise rates. Rapid isolation valve closure is expected to terminate blowdown before a swelling steam-water mixture enters the steam line and forms a mixture slug. For delayed valve closure in steam lines containing a nozzle flow limiter, the impact pressure rise has been calculated to be approximately 200 psi for a steam line break outside the containment. This is the most probable mode of impact loading anticipated during the steam line break accident.

The increase in primary membrane stress as a result of an impact pressure rise of 200 psi is $\Delta \sigma_{\theta}=1970$ psi and $\Delta \sigma_{\mathrm{a}}=985 \mathrm{psi}$.

Stresses are also induced in the main steam line when, because of excessive pressure, the safety valves lift and discharge high-pressure steam. When steam is first discharged from the valves, a jet reaction force is applied to the valve and, in turn. is transmitted through the 6 -in. relief line back into the 24 -in. steam line. Stresses were calculated in the steam line using MASS by applying a force and moment (equivalent to the jet reaction force) to the steam line where it intersects with the relief line.

It was assumed that during a severe overpressure transient, all steam line safety valves ${ }^{(5)}$ could lift simultaneously. However, since the reaction forces of adjacent safety valves are in opposite directions. the most severe loading condition would occur if only four of the valves, oriented in the same direction, were to lift simultaneously. The stresses at the joints of the MASS model caused by this assumed transient are shown in the stress tabulation under the heading of impact stresses. Stresses are tabulated for the south side main steam line: similar stresses will also occur in the north side main steam line at the identical locations.

In addition to the stresses in the 24-in. steam line, there are also stresses induced in the 6-in. relief line which is cantilevered above the steam line. The maximum stress occurs at the intersection of the two pipes as a result of out-of-plane bending produced by the reaction force from the safety valve. The lowest natural frequency of the relief line must be determined in order to ensure that the jet force is applied over a sufficiently long period of time to permit the full bending stress to develop into the relief line. It was found from calculations that the period of vibration 
was of the same magnitude as the time required for the jet of steam to travel from safety valve down the relief line to the vent tee (at which point the jet reaction force is counterbalanced by diverting the steam flow equally in two opposite directions). The stresses calculated in the relief line for this condition were as follows:

$$
\begin{array}{lll}
\text { Primary membrane, } P_{\mathrm{m}} & : \sigma_{1}=\frac{M C}{I}=22,800 \text { psi, } \\
\text { Primary bending. } P_{b} & : & \sigma_{2}= \pm \frac{R_{0}-R_{i}}{2 R_{m}} \sigma_{1}= \pm 1590 \text { psi. }
\end{array}
$$

Secondary membrane +

Bending, Q

where

$$
\begin{aligned}
M= & \begin{array}{l}
\text { bending moment resulting from } \\
\text { jet reaction force, in. }-\mathrm{lb},
\end{array} \\
\mathrm{C}= & \begin{array}{l}
\text { distance from neutral axis to } \\
\text { outer fiber of pipe, in. }
\end{array} \\
\mathrm{I}= & \text { moment of inertia of pipe, in. } \\
\mathrm{R}_{\mathrm{O}}= & \text { outer radius of pipe, in., } \\
\mathrm{R}_{\mathrm{i}}= & \text { inner radius of pipe, in., } \\
\mathrm{R}_{\mathrm{m}=} & \text { mean radius of pipe, in., } \\
\mathrm{C}_{2}= & \text { stress intensification factor for } \\
& \text { tees loaded with an out-of -plane } \\
& \text { bending moment, }
\end{aligned}
$$$$
=\frac{0.9}{\left(\frac{t}{R_{m}}\right)^{2 / 3}}=3.96(2.0 \text { is minimum })
$$

(per ASA B31.1), and

$$
\mathrm{t}=\text { nominal pipe wall thickness, in. }
$$

These values of calculated stress exceed the code allowable stress, thereby indicating the need for a design modification. In actual practice, a design change would be instituted, and the stress level during plant operation would be within the code allowable. In this particular case, the relief lines will have to be stiffened or braced to reduce the excessive stress.

\subsection{TRANSIENT THERMAL STRESS}

Transient thermal stresses were calculated in several BWR piping components to reflect the effect of the predicted transient temperature conditions described in References 9 and 10 . It is not considered essential to calculate transient thermal stresses when using B31. 1 as a design guideline. However, the design requirements of the new nuclear piping code (USAS B31.7) will require that transient stresses be calculated and will provide a method for checking the fatigue life based on the magnitude of the transient stress and the number of cycles. Therefore, the stresses were calculated for this report mainly to illustrate the method of calculation and to point out components and locations where transient stresses are significant. In each instance where the transient temperature distribution was determined, a simplified slab model was chosen to represent the pipe wall. One surface of the slab was assumed to be insulated (adiabatic) while the other surface, when in the presence of water, was assumed to respond directly to water temperature changes. ${ }^{(10)}$ where one 
surface was in the presence of steam (emergency condenser steam line), the surface heat transfer coefficient resulting from condensation of steam was calculated and applied in determining the resulting temperature distribution. ${ }^{(11)}$

The peak stress that resulted in the pipe immediately after the occurrence of the transient was assumed to be a skin stress reflecting the entire temperature change of the fluid. For conservatism, in each case the temperature change of the fluid was assumed to occur in a stepwise fashion. The peak (skin) stress was calculated using the equation,

$\sigma_{\theta}=\sigma_{\mathrm{L}}=\frac{\mathrm{E} \alpha \Delta \mathrm{T}}{1-\nu}$.

In addition to the initial step change in surface temperature, a temperature gradient will exist through the pipe at subsequent intervals of time, the gradient varying from a maximum at the initial time to zero at some later time when the pipe wall approaches a uniform steadystate temperature equal to the fluid temperature (for the model chosen). Since the transient temperature gradient is nonlinear, it can be broken into two parts: an equivalent linear gradient, and a temperature difference between the equivalcnt linear gradient and the actual temperature at the surface of the pipe.

For the model chosen, the temperature gradient through the pipe wall can be calculated for any desired time using the equations and charts given in Reference 12. An equivalent linear temperature gradient can be obtained from this nonlinear gradient by the following equations:

$\mathrm{T}_{\mathrm{e}}(\mathrm{z})=\mathrm{T}_{\text {avg }}+[\operatorname{Grad} \mathrm{T}(\mathrm{z})] \mathrm{z}$,

where

$$
\begin{aligned}
\mathrm{T}_{\mathrm{e}}= & \text { equivalent linear temper- } \\
& \text { ature at } \mathrm{Z},{ }^{\circ} \mathrm{F},
\end{aligned}
$$

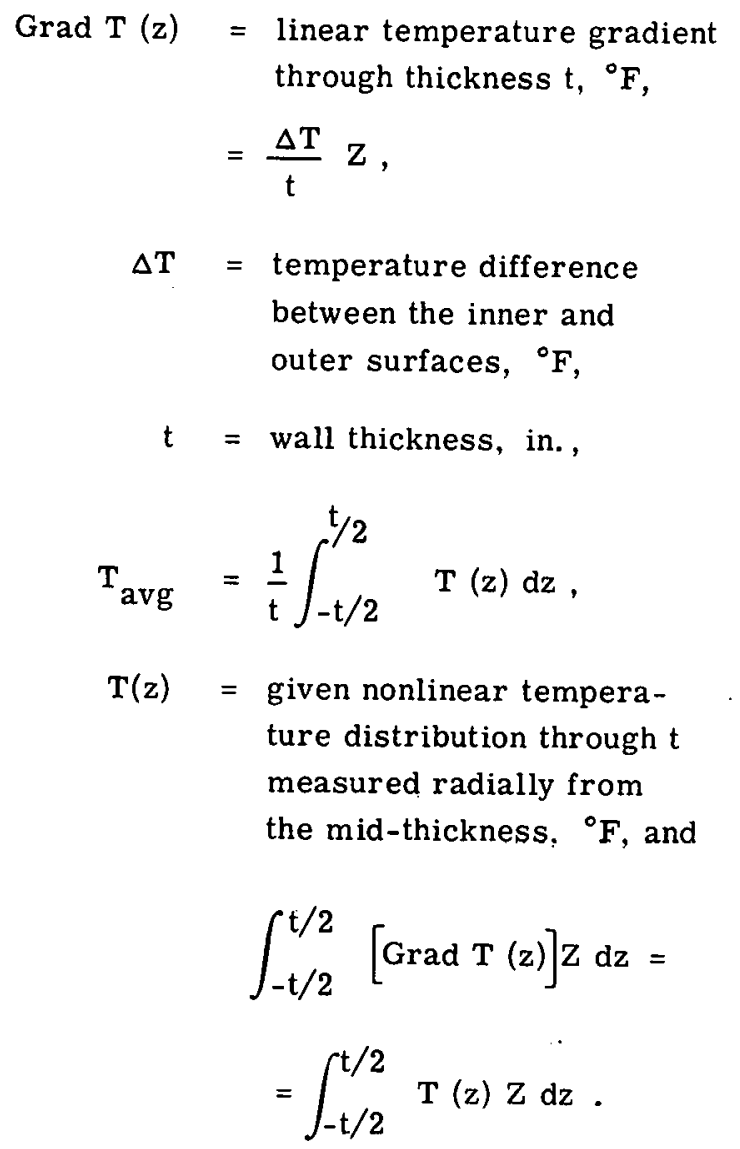

The equivalent linear gradient can be determined as the difference between the values of $T_{e}$ at $\mathrm{Z}=-\mathrm{t} / 2$ and $\mathrm{T}_{e}$ at $\mathrm{Z}=\mathrm{t} / 2$. On the surface of the pipe, thermal stresses are present because of the difference between $T_{e}$ and $T_{\text {actual }}$ at the surface.

Thermal stresses in the pipe wall resulting from the nonlinear temperature gradient at some time after initiation of the transient are expressed using the equivalent linear temperature gradient as follows:

$$
\begin{aligned}
& \sigma_{\theta}=\sigma_{\mathrm{L}} \frac{\mathrm{E} \alpha\left(\mathrm{T}_{\mathrm{e}_{\text {in }}}-\mathrm{T}_{\mathrm{e}_{\text {out }}}\right)}{2(1-\nu)} \begin{array}{c}
\text { (Secondary } \\
\text { Stress) }
\end{array} . \\
& \sigma_{\theta}=\sigma_{\mathrm{L}}=\frac{E \alpha\left[\left(\mathrm{T}_{\mathrm{e}}-\mathrm{T}_{\text {actual }}\right)\right]_{\text {Surface }}}{1-\nu}
\end{aligned}
$$

(Peak Stress) . 
A summary of the transient thermal stresses that exist in several of the primary lines of the BWR piping system is given in Table 5. These stresses are categorized as the peak stress that occurs at time $0^{+}$, the secondary stress that results from the maximum equivalent linear temperature gradient at some later time, and the associated peak stress that occurs simultaneously with the secondary stress. The temperature transient that causes the stress and the number of the thermal cycles anticipated for each transient are also given in the table.

It was beyond the scope of this study to determine the axial variation in the transient radial temperature gradient. However, for conservatism, it can be assumed that the maximum transient thermal stress (those values tabulated in Table 5) occurs at each joint in a pipe which is either cold and suddenly heated, or hot and suddenly cooled. Discontinuities, stress concentrations, and other local effects were not considered.

\subsection{VIBRATION STRESS}

During reactor plant operation, vibration can be induced in piping in many ways; e. g. , by any kind of reciprocating equipment, by rotating equipment because of mass unbalance, by operation of relief valves, safety valves or other similar devices, and by the fluid flow itself. Significant vibration problems are difficult to predict in the early stages of piping design because of the many complicated effects associated with pipe vibration; however, every effort should be made during the design phase to arrange and support the piping so as to minimize vibration. In addition, observation of the piping system during startup and the initial phases of operation to detect any undesirable vibration is also of primary importance.

A very good discussion of vibration in piping systems is contained in Chapter 9 of Reference 13, entitled "Vibration Prevention and Control." Included in that chapter is a discussion of basic vibration theory, typical vibration problems in piping systems and trouble shooting procedures. This reference is of most value to the designer who is attempting to minimize vibration during the design and layout phase of piping design. Little, if any, aid in outlining methods or procedures for determining dynamic stresses in piping systems can be obtained from any of the piping or vessel design codes.

However, in considering vibration, it should be emphasized that in order to comply with USA B31.7, it will be the designer's responsibility to show, through design and observation, that vibration has been minimized to an acceptable value.

Therefore, a procedure must be established whereby the vibration of a piping system can be observed and measured under startup and initial operating conditions in order to ensure that vibration is within the acceptable limits dictated by the applicable design codes.

In determining an allowable stress for vibration, the designer must give consideration to all other simultaneous stresses that occur; then the margin between the sum of these stresses (summed according to B31.7) and the allowable stress intensity (per B31.7) is available for vibration.

The following procedure is suggested for calculating an allowable single amplitude vibration stress level. It is necessary to refer to the "hopper" diagram, Table I-702.5.5 of B31.7, for clarification of nomenclature.

a. Calculate the stresses that result from all forms of loading at each point of interest in the piping system. The loading conditions may include pressure, mechanical load, thermal expansion, local thermal, impact, earthquake, and nondesign, both 
TABLE 5

SUMMARY OF TRANSIENT THERMAL STRESSES

System

Condition

Sub-Model 1

Top Head Cooling Spray Sub-Model 2

Core Spray Near Pressure

Feedwater Line Near

Sub-Model 3

Control Rod Drive Cooling
Water Supply Line

Control Rod Drive Hydraulic
System Return Line

Poison Spray Line Near
Pressure Vessel

Sub-Model 4

Emergency Condenser Steam Sub-Model 5

Emergency Condenser

Sub-Model 6

Cleanup to Recirculation Tee

Sub-Model 7

All Recirculation Loop Piping Sub-Model 8

Shutdown Loop
Normal reactor shutdown

Accidental loss of core coolant

Normal reactor startup, cold

feedwater enters hot recirculation

Will no cooling, housing heats to
$150^{\circ} \mathrm{F}$. Resumption o cooling

lowers temperature to $50 \mathrm{~F}$.

Cold return water enters hot line
near pressure vessel

Cold poison enters hot spray
line near pressure vessel

Hot steam enters cold steam line

Cold condensate enters hot

Cold cleanup water enters hot

recirculation line

Loop shutdown, cools to ambient,

Improper startup of shutdown

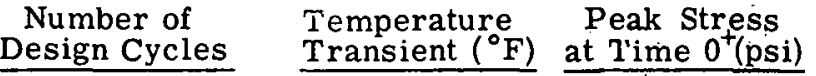

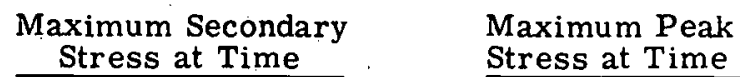
(Not including stress concentrations)

120

545 to 110

545 to 100

200
150 to 50

545 to 50

545 to 100

100 to 545

545 tri, 100

545 to 100

100 to 545

130 to 530
112,000

156,500

$116,000^{\circ}$

50,500 psi at $0.3 \mathrm{sec}$

$26,000 \mathrm{psi}$ at $0.3 \mathrm{sec}$

$70,000 \mathrm{psi}$ at $3 \mathrm{sec}$

52,000 psi at $5 \mathrm{sec}$

$46.000 \mathrm{psi}$ at $3 \mathrm{sec}$

$20,300 \mathrm{psi}$ at $5 \mathrm{sec}$

36,000

178,000

160,000

$-$

160,000

160,000

160,000

144,000
16. $200 \mathrm{psi}$ at $0.2 \mathrm{sec}$

80,000 psi at $5 \mathrm{sec}$

$30,000 \mathrm{psi}$ at $5 \mathrm{sec}$

72,000 psi at $5 \mathrm{sec}$

$27,000 \mathrm{psi}$ at $5 \mathrm{sec}$

\section{$30,230 \mathrm{psi}$ at $45 \mathrm{sec}$}

6,750 psi at $45 \mathrm{sec}$

$72,000 \mathrm{psi}$ at $5 \mathrm{sec}$

$38,100 \mathrm{psi}$ at $5 \mathrm{sec}$

$72,000 \mathrm{psi}$ at $5 \mathrm{sec}$

38,100 psi at $5 \mathrm{sec}$

71,500 jsi at 5 sec

$37,800 \mathrm{psi}$ at $5 \mathrm{sec}$

$64,700 \mathrm{psi}$ at $10 \mathrm{sec}$
$9,620 \mathrm{psi}$ at $0.2 \mathrm{sec}$

33. $500 \mathrm{psi}$ at $10 \mathrm{sec}$ 
steady state and transient, and should include the effects of discontinuities and stress concentrations where these are called for in the "hopper" diagram.

b. Combine all of these stresses in the manner prescribed by B31. 7 and compare the combined stress (e.g. , $P_{m}, P_{L}, P_{e}$, etc.) with the allowable stress intensity $\left(\mathrm{S}_{\mathrm{m}}, 1.5 \mathrm{~S}_{\mathrm{m}}\right.$ or $3 \mathrm{~s}_{\mathrm{m}}$ ), as shown in the "hopper" diagram.

c. The minimum difference between the calculated combined stress and the allowable stress should be determined for each category where vibration must be considered. For example, calculate $P_{m}, P_{L}+P_{b}, P_{L}+P_{b}+P_{e}+$ $Q$ and $P_{L}+P_{b}+P_{e}+Q+F$, and then determine the following quantities:

$$
\begin{aligned}
& \text { 1. } 1.5 \mathrm{~S}_{\mathrm{m}}-\mathrm{P}_{\mathrm{L}}=\mathrm{A} \\
& \text { 2. } 1.5 \mathrm{~S}_{\mathrm{m}}-\left[\mathrm{P}_{\mathrm{L}}\left(\text { or } \mathrm{P}_{\mathrm{m}}\right)+\mathrm{P}_{\mathrm{b}}\right]=\mathrm{B} \\
& \text { 3. } 3 \mathrm{~S}_{\mathrm{m}}-\left[\mathrm{P}_{\mathrm{L}}\left(\text { or } \mathrm{P}_{\mathrm{m}}\right)+\mathrm{P}_{\mathrm{b}}+\mathrm{P}_{\mathrm{e}}+\mathrm{Q}\right]=\mathrm{C}
\end{aligned}
$$

4. Single amplitude vibration stress (including discontinuities and stress concentrations) acting alone $=\mathrm{D}$.

The additional stress produced by vibration should be limited to the minimum of $A, B$, $C$, or D. However, in no case should the stress resulting from vibration be permitted to exceed the endurance limit of the material (assumed to to be equal to $S_{A}$ at $10^{6}$ cycles on Figures 1-702.5.7 (a) and 1-702.5.7 (b) in B31.7). Since vibration at only $1 \mathrm{cps}$ amounts to a total of $1.26 \times 10^{9}$ cycles after 40 years, it is apparent that the significant design parameter when considering vibration is not $3 \mathrm{~S}_{\mathrm{m}}$ but rather the endurance limit of the material.
If there is a large margin of stress available to accommodate vibration (i. e., if the minimum of $A, B, C$, or $D=$ the endurance limit), then the presence of excess vibration in the system is more readily detectable since a large vibratory stress will likely be accompanied by a large amplitude of vibration. However, as a design guide, it is suggested that the maximum single amplitude stress attributable to vibration be limited to the following values:

Maximum single amplitude stress from vibration alone

$$
\begin{array}{ll}
\text { Carbon Steel } & =5,000 \mathrm{psi} \\
\text { Stainless Steel } & =10,000 \mathrm{psi}
\end{array}
$$

These values of stress give a safety margin of about 2.5 below the minimum fatigue stress of USA B31. 7 for these materials. This should be ample to account for stress intensification at discontinuities (branches, tees, etc.).

Simplified relationships can be derived for sections of piping which may be treated as fixed-fixed, fixed-hinged, or cantilever beams. ${ }^{(14)}$ but these do not account for the complicated interaction of long runs of pipe containing pumps, valves, dampers, stops, etc.

It can be shown, using these simple piping models, that for a given allowable stress and maximum frequency of vibration (typically less than 150 for low-cycle fatigue damage considerations), the amplitude of vibration in the piping model (or system) should not exceed a calculated maximum value. This value of amplitude--which again depends upon the total stress that exists at the piping joint before the vibration stress is superimposedmay be $1 / 16$ inch peak-to-peak ${ }^{(13)}$ for large pipe (over 12-in. diameter). However, it is recommended that the maximum permissible peak-to-peak amplitude of vibration for a 
frequency of $150 \mathrm{cps}$ (probably the maximum frequency of interest) be limited to the following values:

Maximum permissible $p-p$ vibration amplitude Carbon Steel $\cdot(S=5,000)=0.033$ in. $p-p$ Stainless Steel $\quad(S=10,000)=0.066$ in. $p-p$

For frequencies, F, less than $150 \mathrm{cps,}$ the maximum permissible amplitude can be increased by the ratio of 150/F: A handy rule might be: "If you observe more than $1 / 32$ in. $p-p$ for carbon steel or $1 / 16$ in. $\mathrm{p}-\mathrm{p}$ for stainless steel pipe, take careful measurements, determine the dominant frequencies, and report results to the designer."

When the stress analysis indicates that the margin of stress available for vibration (i. e., A, B, C, or D) is considerably. less than the maximum values recommended above, the designer should consider the economics (and technical feasibility) of redesigning the piping system (including another iteration of stress analysis) to permit a higher vibratory stress versus the employment of sensitive instrumentation for the detection and measurement of the small vibration permitted by the stress limits. It would seem desirable to be able to perform all vibration. "measurements" by visual observation of the piping system during startup and initial operation.

A sophisticated piping vibration analysis which would give calculated stresses at each pipe joint in the model for comparison with the allowable stress at those points (after other simultaneous stress has been considered) is beyond the scope of the pipe rupture study. Although possible to perform such an analysis, it is anticipated that in actual practice vibration will be acceptably. accounted for by judicious design and by observation after initial plant startup.

SECTION $V$

\section{APPLICATION TO CRACK INITIATION AND CRACK PROPAGATION STUDIES}

Numerical results from this report will be utilized in calculating the probability of crack initiation and propagation through to leak in the primary system as a result of low cycle fatigue, taking into account the stress values at each component and the estimated uncertainty in those values. A description of the method by which this is accomplished is documented elsewhere. (15) The purpose of this discussion is to show how the calculated stresses will be utilized in the crack initiation and crack propagation equations.

\subsection{SOURCES OF CYCLIC STRESS}

The stresses of primary importance in crack initiation and crack propagation studies are the thermal expansion stresses, $S_{E}$, which have been calculated, and the pressure stresses
$S_{p}$, which are readily calculated from nominal pipe dimensions: These stress cycles are associated with reactor startup and shutdown, for which the reactor design basis is 120 cycles in 40 years. Weight stresses and possible earthquake and impact stresses have also been calculated, but consideration of these stresses is appropriate to analysis of the later phases of possible piping failure, rather than the crack initiation and fatigue crack propagation phases. The transient thermal stresses, summarized in Table 5 , should be considered for those particular lines and components in which they occur.

\subsection{SIMPLIFIED INTERPRETATION OF PIPING STRESSES}

Some simplifying assumptions regarding the orientation of the thermal expansion 
stresses in straight and curved components are necessary to permit superposition of expansion stresses and pressure stresses. These simplifications will also permit a potential fatigue crack to be identified as either circumferentially or axially oriented, and thus avoid the complexities of a consideration of skew-oriented cracks. In the straight pipe section, $S_{E}$ is the maximum difference of principal stresses resulting from bending and torsional moments in the pipe. These principal stresses may actually be oriented at an angle to the axis of the pipe as a result of the torsional component, but it will be assumed that $S_{E}$ is due to bending only, and represents a uniaxial stress parallel to the axis of the pipe.

In the curved pipe section, $S_{E}$ is an estimate, based on Piping Cude rules, of the effective stress for fatigue crack initiation resulting from a combination of in-plane, out-of-plane, and torsional moments in the pipe. The actual stress distribution in the piping elbow is more complex than is implied by the method of calculation of $S_{E}$, but it will be assumed that $S_{E}$ is the stress resulting from bending to oval shape of the elbow cross section. Then $S_{E}$ is oriented in the transverse, or circumferential direction in the elbow.

The pressure stresses in all components are approximated by the simple equations:

Circumferential stress $=S_{p}=\frac{P r}{t}$, Axial stress $=\frac{1}{2} S_{p}$,

where

$$
\begin{aligned}
& \mathbf{P}=\text { pressure, psi, } \\
& \mathbf{r}=\text { mean pipe radius, and } \\
& \mathbf{t}=\text { pipe wall thickness. }
\end{aligned}
$$

The transient thermal stresses, which will be denoted $S_{T}$, are the values taken from Table 5, in the column marked "Peak Stress at Time $0+. "$

\subsubsection{Crack Initiation}

The general criterion for low-cycle fatigue crack initiation in piping materials is the experimental correlation that is observed between the cyclic shear strain range (or effective strain) and cycles to crack initiation. It is customary in design work to recognize, or assume, that an effective stress calculated by elastic theory is approximately in direct proportion to the actual value of effective strain, even though the limitations of elastic theory have been exceeded. The validity of this assumption has been the subject of investigations conducted under Task D-2 of the Pipe Rupture Study. (16) The proportionality of calculated stress and actual strain will be assumed in the piping system reliability model. Figures 22 through 24 show the low-cycle fatigue data which are the basis for ASME code design rules, (17) and will be used as the criterion for low-cycle fatigue crack initiation in the reliability model. An important consideration in the low-cycle fatigue crack initiation criterion is the effect of surface finish and/or initial defect size on cycles to crack initiation, with reference to smooth-bar laboratory test data. If the surface defect has a sharp edge, it can be treated as an initial crack, but if the defect has a finite tip radius, there will be a crack initiation or "incubation" period which can be predicted by the use of a stress concentration factor applied to the nominal effective stress in the region. of the defect.

The effective stress amplitude $\mathrm{S}_{\mathrm{a}}$ for fatigue crack initiation due to startup and shutdown cycles will be given by:

$S_{a}=\frac{K}{2} \quad\left(S_{E}+\frac{1}{2} S_{p}\right)$ 


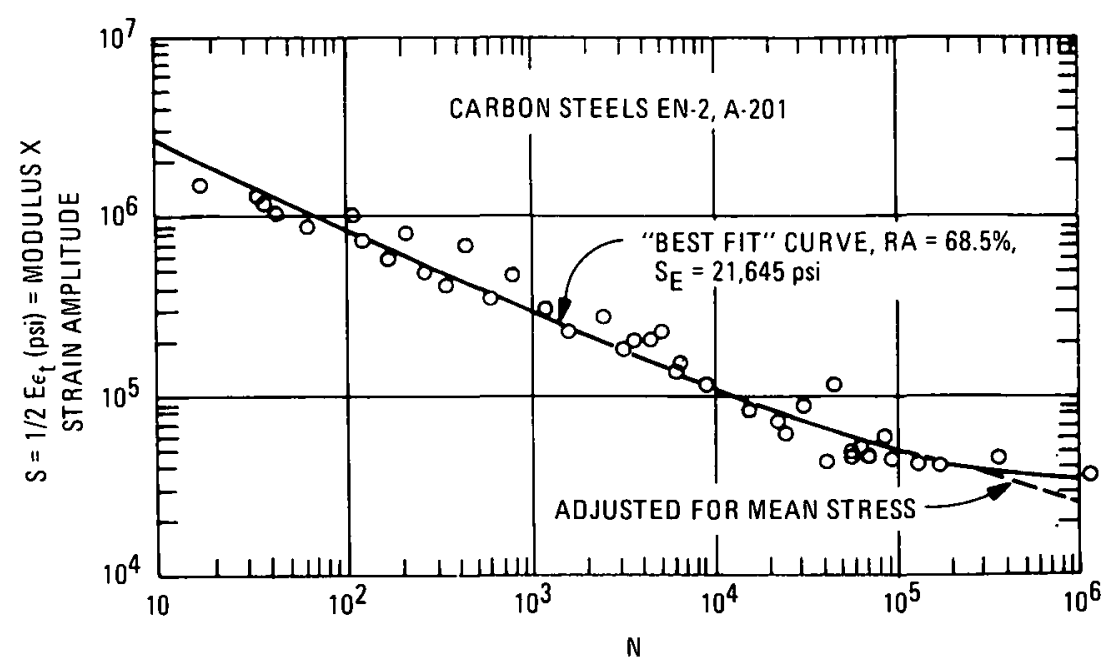

FIGURE 22. FATIGUE DATA-CARBON STEELS

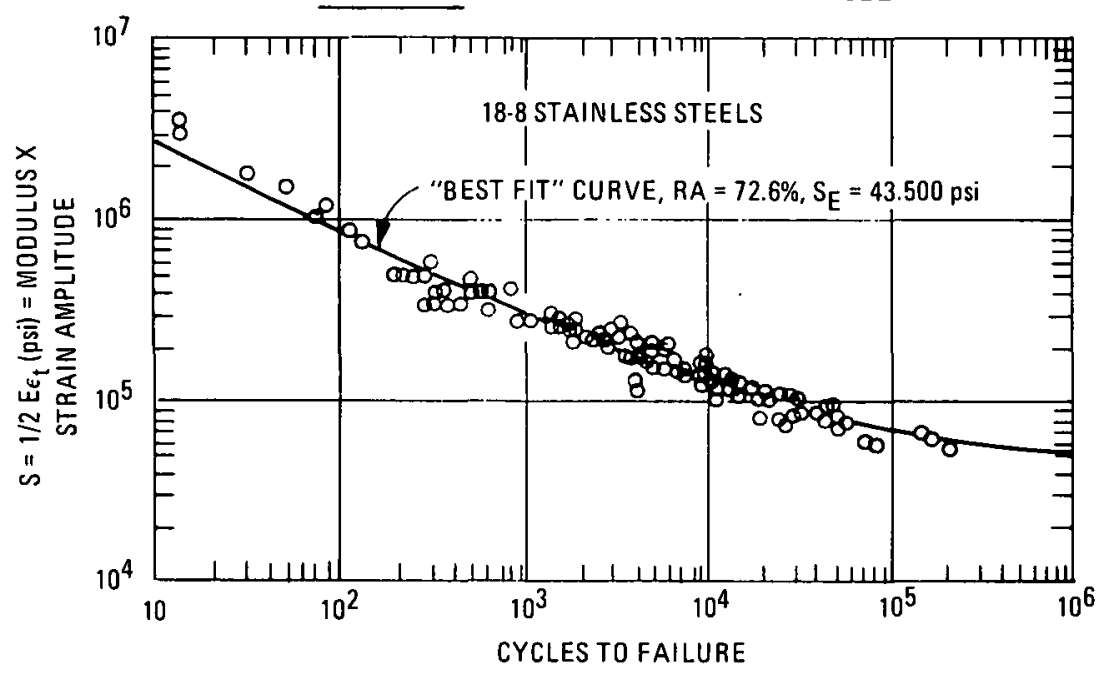

FIGURE 23. FATIGUE DATA-STAINLESS STEELS

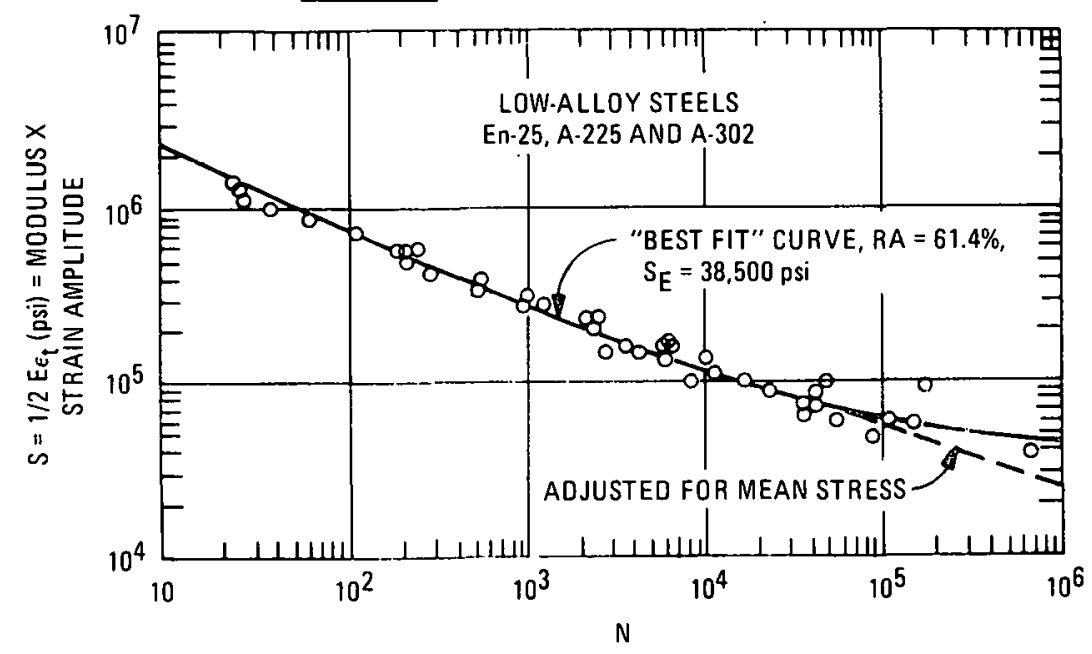

FIGURE 24. FATIGUE DATA-LOW.ALLOY STEELS 
for straight pipe sections, or

$$
\begin{aligned}
& S_{a}=\frac{K}{2} S_{p} \\
& S_{a}=\frac{K}{2}\left(S_{E}+S_{p}\right),
\end{aligned}
$$

for curved pipe sections.

For transient thermal cycles, $\mathrm{S}_{\mathrm{a}}=\frac{\mathrm{K}}{2} \mathrm{~S}_{\mathrm{T}}$, for all affected components. In these expressions, $\mathrm{K}$ is the defect stress concentration factor given by

$\mathrm{K}=1+2 \sqrt{\frac{\mathrm{a}_{\mathrm{o}}}{\mathrm{r}}}$,

$a_{0}=$ defect depth,

$r=$ effective tip radius of defect.

The distribution of $a_{0}$ has been estimated. (15) A distribution for $r$ will be similarly assigned, with care taken to ensure that a normal piping component surface finish is characterized by a reasonably small value of $K$. While this may seem to be a cumbersome way to represent the low-cycle fatigue behavior of piping components, it has the advantage of providing a consistent mathematical definition of the crack initiation and crack propagation phases, and permits the use of probability density functions defined by the Reliability Engineering Task for the pertinent variables.

\subsubsection{Crack Propagalion}

Four categories of stress in a pipe wall have been identified in the analysis of fatigue crack propagation through the pipe wall, as follows:
a. Primary membrane,
b. Primary bending;
c. Secondary membrane, and
d. Secondary bending.

The terms, membrane and bending, refer to stresses that act normal to the plane of the crack and are uniformly distributed or linearly distributed, respectively, through the pipe wall thickness. The secondary stress categories are, by definition, those nominal stresses that are reduced in magnitude as the crack depth increases, as a result of increased local flexibility due to the presence of the crack. The primary stress categories are load-dependent and do not decrease with increasing crack depth.

The proper classification of stresses in a piping component into primary and secondary categories requires the stress analysis of the component with the equivalent crack flexibility included. This type of analysis is not yet feasible with the present state of development stress analysis techniques, but more important, there is evidence from preliminary calculations using'the crack growth equation, that the primary versus secondary distinction will not be necessary in most cases. If the initial crack depth is small compared to the pipe wall thickness, then a very large proportion of the total number of cycles to grow through the wall is consumed while the crack is short and the primary versus secondary distinction is not significant. Furthermore, it is estimated that primary stresses predominate in most of the piping components. It will be expedient, conservative, and apparently quite accurate, then to omit the secondary stress categories from the crack growth equation, with the possible exception of special cases of local thermal stresses which can be considered separately.

The stresses to be used in the crack propagation equation may now be defined, using the following nomenclature:

$$
\begin{aligned}
& \sigma_{\mathrm{pM}}=\text { primary membrane stress, } \\
& \sigma_{\mathrm{pB}}=\text { primary bending stress. }
\end{aligned}
$$


The -stress values appropriate to startup and shutdown cycles will depend on $S_{E}$ and $S_{p}$, and are determined as follows.

For the straight pipe section, use the larger of

$\sigma_{\mathrm{pM}}=\dot{S}_{\mathrm{E}}+\frac{1}{2} \mathrm{~S}_{\mathrm{p}}$ (crack has a circum-

ferential orientation),

or

$\sigma_{\mathrm{pM}}=\mathrm{S}_{\mathrm{p}}$ (crack has an axial orientation),

with

$\sigma_{\mathrm{pB}}=0$

For the piping elbow, $\sigma_{\mathrm{pM}}=\mathrm{S}_{\mathrm{p}}$ and $\sigma_{p B}=S_{E}$, and the crack is orientated in the axial (longitudinal) direction.
For transient thermal cycles,

$\sigma_{\mathrm{pM}}=0$

and

$\sigma_{\mathrm{pB}}=0$

for all affected components.

This thermal stress would be more accurately considered as a secondary rather than a primary stress, but as noted previously, the distinction will not be significant in the final results, and elimination of secondary stress categories will simplify the calculation procedure and provide a conservative result. 
This stress calculation is given in Reference 18.

\section{A. 1 LONGITUDINAL BENDING} STRESS. $S_{B}$

a. Straight Tubes

$$
\begin{aligned}
\mathrm{S}_{\mathrm{B}}= & \frac{\mathrm{Mr}}{\mathrm{I}}, \\
\mathrm{M}= & \sqrt{\mathrm{M}_{\mathrm{i}}^{2}+\mathrm{M}_{\mathrm{O}}^{2}}, \\
\mathrm{M}_{\mathrm{i}}= & \begin{array}{l}
\text { in-plane bending } \\
\text { moment. }
\end{array} \\
\mathrm{M}_{\mathrm{O}}= & \begin{array}{l}
\text { out-of-plane bend- } \\
\text { ing moment. }
\end{array}
\end{aligned}
$$

b. Curved Tubes

$$
\begin{aligned}
S_{B}=\frac{M r}{I} i & \\
i & =\begin{array}{l}
\text { stress intensification } \\
\text { factor, }
\end{array} \\
i & =\frac{0.9}{(h)^{2 / 3}}, \\
h & =\frac{t_{\rho}}{r^{2}} .
\end{aligned}
$$

A. 2 AXIAL STRESS, $\mathrm{S}_{A}$

Axial stress. $\mathrm{S}_{\mathrm{A}}$, is neglected by ASA Code and No. 1052 stress calculation.

\section{A. 3 TORSIONAL STRESS, $\mathrm{S}_{\mathrm{T}}$}

$$
\begin{aligned}
& \mathrm{S}_{\mathrm{T}}=\frac{\mathrm{M}_{\mathrm{T}^{\mathrm{r}}}}{2 \mathrm{I}} \\
& \mathrm{M}_{\mathrm{T}}=\text { torsional moment }
\end{aligned}
$$

\section{A. 4 PRESSURE STRESSES}

a. Longitudinal Pressure Stress

$$
\begin{aligned}
S_{L P}= & \frac{A_{i}}{A_{m}} . \\
P & =\text { pressure. } \\
A_{i}= & \text { inside tube area. } \\
A_{m}= & \begin{array}{l}
\text { cross-sectional area } \\
\text { of metal. }
\end{array}
\end{aligned}
$$

b. Hoop Stress

$$
S_{H}=P \frac{(D-t)}{2 t}
$$

\section{A. 5 COMBINED STRESSES}

The effective stress printed out at each joint inputted to MASS is a combined stress based on llie Maximum Shear Theory. This effective stress is the maximum of

$$
\mathrm{S}_{\mathrm{EFF}}=0.5\left[\mathrm{~S}_{\mathrm{L}}+\mathrm{S}_{\mathrm{H}} \pm \sqrt{4 \mathrm{~S}_{\mathrm{T}}^{2}+\left(\mathrm{S}_{\mathrm{L}}-\mathrm{S}_{\mathrm{H}}\right)^{2}}\right]
$$

or

$$
\sqrt{4 S_{T}^{2}+\left(S_{L}-S_{H}\right)^{2}}
$$

where

$S_{L}=S_{B}+S_{A}+S_{L P}$

\section{A. 6 COMPARISON OF STRESS CALCULATION 1052 WITH ASA CODE}

With axial stress neglected by the stress calculation:

$\mathrm{S}_{\mathrm{A}}=0$. 
With no pressure inputted into the model:

$\mathrm{S}_{\mathrm{LP}}=0$,

and

$\mathrm{S}_{\mathrm{H}}=0$.

Therefore, the stress printed out by MASS stress calculation 1052 with no pressure inputted is

$$
\sqrt{4 S_{T}^{2}+S_{B}^{2}}
$$

This is equivalent to the calculation for the expansion stress, $S_{E}$, given in the ASA code reference 1 . 
GEAP-5724

APPENDIX B

TABULATION OF COMPONENTS AND DISCONTINUITIES

IN A TYPICAL SINGLE-CYCLE BWR 


\begin{tabular}{|c|c|c|c|c|c|c|c|c|c|c|c|c|c|c|c|c|c|c|c|c|c|}
\hline $\begin{array}{c}\text { Model Number } 1 \\
\text { Main Steam (North Side) } \\
\text { Component } \\
\text { or Discontinuity } \\
\end{array}$ & 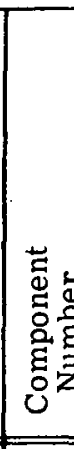 & $\underset{F}{2}$ & 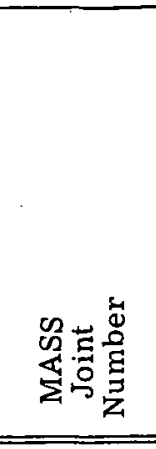 & 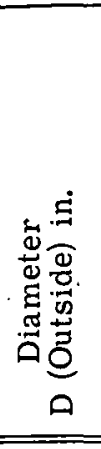 & 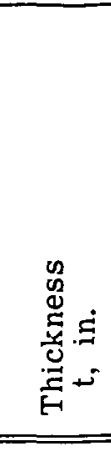 & 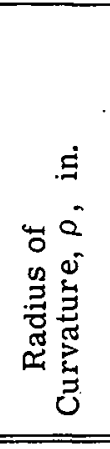 & 茪 & 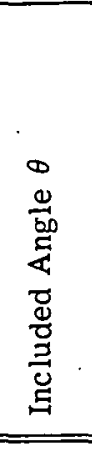 & 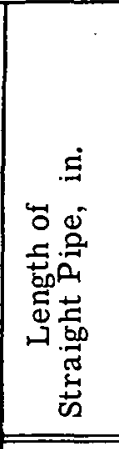 & 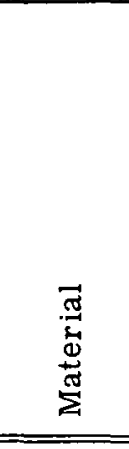 & 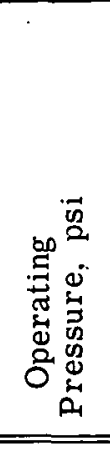 & 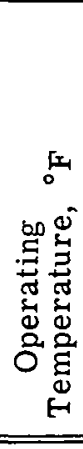 & 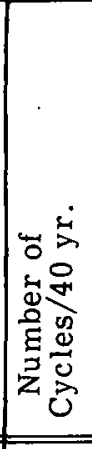 & 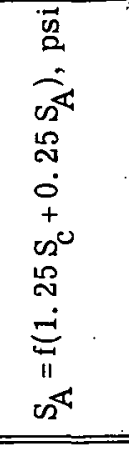 & 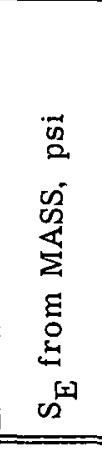 & $\begin{array}{l}0^{4} \\
0 \\
0\end{array}$ & 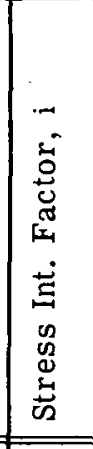 & 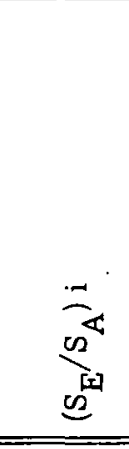 & 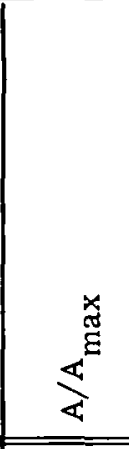 & 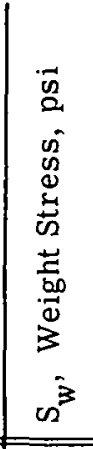 & 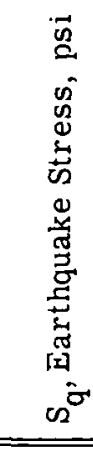 \\
\hline $\begin{array}{l}\text { Pressure Vessel } \\
\text { Nozzle Weld }\end{array}$ & & D-1 & 501 & & & & & & & & & & & & 3047 & 0.1167 & 11.0 & 0.1161 & & 51 & 1260 \\
\hline Straight & 1 & 1 & $501-502$ & 24.0 & 1.218 & & & & 11.0 & A $106 \mathrm{C}$ & 1000 & 555 & 360 & 26,250 & 3047 & 0.1167 & & 0.1161 & 0.8055 & 51 & 1106 \\
\hline Butt Weld & & $D-1$ & 502 & & & & & & & & & & & & 3595 & 0.1370 & 1.0 & 0.1370 & & 86 & 1216 \\
\hline Elbow & 2 & 2 & $502-503$ & 24.0 & 1.218 & 24.0 & 1.0 & $90^{\circ}$ & & A106C & 1000 & 555 & 360 & 26.250 & 6247 & 0.2380 & & 0.2380 & 0.8055 & 108 & 3200 \\
\hline Butt Weld & & D-1 & 503 & & & & & & & & & & & & 6247 & 0.2380 & 1.0 & 0.2380 & & 108 & 1325 \\
\hline Straight & 3 & 1 & $503-504$ & 24.0 & 1. 218 & & & & 224.0 & A $106 \mathrm{C}$ & 1000 & 555 & 360 & 26,250 & 2570 & 0.0979 & & 0.0979 & 0.8055 & 97 & 436 \\
\hline Flow Nozzle & & $D-3 a$ & $\begin{array}{l}\text { Between } \\
503 \& 504\end{array}$ & & & & & & & & & & & & & & & & & & \\
\hline Bend & 4 & 3 & $504-505$ & 24.0 & 1.218 & 144.0 & 6.0 & $15^{\circ}$ & & A106C & 1000 & 555 & 360 & 26,250 & 709 & 0.0270 & & 0.0270 & 0.8055 & 181 & 394 \\
\hline Straight & 5 & 1 & $505-506$ & 24.0 & 1.218 & & & & 165.5 & A106C & 1000 & 555 & 360 & 26,250 & 3002 & 0.1144 & & 0.1144 & 0.8055 & 181 & 788 \\
\hline Butt Weld & & $D-1$ & 506 & & & & & & & & & & & & 5561 & 0.2153 & 1.0 & 0.2153 & & 207 & 1454 \\
\hline Elbow & 6 & 2 & $506-507$ & 24.0 & 1.218 & 36.0 & 1.5 & $90^{\circ}$ & & A106C & 1000 & 555 & 360 & 26.250 & 5561 & 0.2153 & & 0.2153 & 0.8055 & 207 & 1385 \\
\hline Butt Weld & & $\mathrm{D}-1$ & & & & & & & & & & & & & 4893 & 0.1864 & 1.0 & 0.1864 & & 206 & 873 \\
\hline Straight & 7 & 1 & $507-508$ & 24.0 & 1.218 & & & & 9.0 & $\Lambda 106 \mathrm{C}$ & 1000 & 555 & 360 & 26,250 & 3026 & 0.1153 & & 0.1153 & 0.8055 & 144 & 735 \\
\hline 6 in. Line to Safety Valve & & $D-4$ & 508 & & & & & & & & & & & & 2916 & 0.1111 & 1.54 & 0.1711 & & 142 & 722 \\
\hline Straight & 8 & 1 & $508-509$ & 24.0 & 1.218 & & & & 30.0 & A106C & 1000 & 555 & 360 & 26,250 & 2916 & 0.1111 & & 0.1111 & 0.8055 & 142 & 722 \\
\hline 6 in. Line to Safety Valve & & $\mathrm{D}-4$ & 509 & & & & & & & & & & & & 2583 & 0.0984 & 1.54 & 0.1520 & & 118 & 695 \\
\hline Bend & 9 & 3 & $509-510$ & 24.0 & 1.218 & 130.0 & 5.5 & $15^{\circ}$ & & A106C & 1000 & 555 & 360 & 26,250 & 2585 & 0.0985 & & 0.0985 & 0.8055 & 142 & 711 \\
\hline 6 in. Line to Safety Valve & & D-4 & 510 & & & & & & & & & & & & 2218 & 0.0845 & 1.54 & 0.1300 & & 142 & 711 \\
\hline Bend & 10 & 3 & $510-511$ & 24.0 & 1.218 & 130.0 & 5.5 & $16^{\circ}$ & & A106C & 1000 & 555 & 360 & 26,250 & 2218 & 0.0845 & & 0.0845 & 0.8055 & 319 & 798 \\
\hline 6 in. Line to Safety Valve & & $\mathrm{D}-4$ & 511 & & & & & & & & & & & & 1758 & 0.0670 & 1.54 & 0.1030 & & 319 & 798 \\
\hline Bend & 11 & 3 & $511-512$ & 24.0 & 1.218 & 130.0 & 5.4 & $14^{\circ}$ & & A106C & 1000 & 555 & 360 & 26.250 & 1758 & 0.0670 & & 0.0766 & 0.8055 & 319 & 795 \\
\hline 6 in. Line to Safety Valve & & D-4 & & & & & & & & & & & & & 1305 & 0.0497 & 1.54 & .0766 & & 108 & 795 \\
\hline Straight & 12 & 1 & $512-513$ & 24.0 & 1.218 & & & & 42.0 & A106C & 1000 & 555 & 360 & 26,250 & 1305 & 0.0497 & & 0.0766 & 0.8055 & 108 & 788 \\
\hline 6 in. Line to Safety Valve & & $\mathrm{D}-4$ & & & & & & & & & & & & & 826 & 0.0315 & 1.54 & 0.0485 & & 91 & 788 \\
\hline Straight & 13 & 1 & $513-514$ & 24.0 & 1.218 & & & & 30.0 & A106C & 1000 & 555 & 360 & 26,250 & 826 & 0.0315 & & 0.0315 & 0.8055 & 166 & 781 \\
\hline 6 in. Line to Safety Valve & & $\mathrm{D}-4$ & & & & & & & & & & & & & 823 & 0.0314 & 1.54 & 0.0484 & & & \\
\hline Straight & 14 & 1 & $514-515$ & 24.0 & 1.218 & & & & 30.0 & A106C & 1000 & 555 & 360 & 26,250 & 1128 & 0.0430 & & 0.0662 & 0.8055 & 166 & 781 \\
\hline 6 in. Line to Safety Valve & & D-4 & & & & & & & & & & & & & 1128 & 0.0430 & 1.54 & 0.0662 & & 191 & 775 \\
\hline Straight & 15 & 1 & $515-516$ & 24.0 & 1.218 & & & & 30.0 & A106C & 1000 & 555 & 360 & 26,250 & 1571 & 0.0598 & & 0.0662 & 0.8055 & 191 & 845 \\
\hline 6 in. Line to Safety Valve & & $D-4$ & 516 & & & & & & & & & & & & 1571 & 0.0598 & 1.54 & 0.0921 & & 166 & 812 \\
\hline Straight & 16 & 1 & $516-517$ & 24.0 & 1.218 & & & & 12.0 & $\mathrm{~A} 106 \mathrm{C}$ & 1000 & 555 & 360 & 26,250 & 1745 & 0.0665 & & 0.0665 & 0.8055 & 164 & 883 \\
\hline Butt Weld & & $\mathrm{D}-1$ & 517 & & & & & & & & & & & & 3045 & 0.1160 & 1.0 & 0.1160 & & 224 & 1510 \\
\hline Elbow & 17 & 2 & $517-518$ & 24.0 & 1.218 & 36.0 & 1.5 & $90^{\circ}$ & & A106C & 1000 & 555 & 360 & 26,250 & 3617 & 0.1378 & & 0.1378 & 0.8055 & 224 & 1392 \\
\hline Butt Weld & & $\mathrm{D}-1$ & 518 & & & & & & & & & & & & 3524 & 0.1342 & 1.0 & 0.1342 & & 150 & 969 \\
\hline Straight & 18 & 1 & $518-519$ & 24.0 & 1.218 & & & & 204.0 & A $106 \mathrm{C}$ & 1000 & 555 & 360 & 26,250 & 1947. & 0.0742 & & 0.1340 & 0.8055 & 87 & 1302 \\
\hline Branch from Vent Line & & $\mathrm{D}-4$ & & & & & & & & & & & & & 2285 & 0.0870 & 1.54 & 0.1340 & & 64 & 3084 \\
\hline Elbow & 19 & 2 & $519-520$ & 24.0 & 1.218 & 24.0 & 1.0 & $90^{\circ}$ & & A106C & 1000 & 555 & 360 & 26,250 & 2644 & 0.1001 & & 0.1340 & 0.8055 & 186 & 2269 \\
\hline
\end{tabular}




\begin{tabular}{|c|c|c|c|c|c|c|c|c|c|c|c|c|c|c|c|c|c|c|c|c|c|}
\hline $\begin{array}{l}\text { Model Number } 1 \\
\text { Main Steam (North Side), } \\
\text { Stéam Relief Line } \\
\begin{array}{c}\text { Component } \\
\text { or Discontinuity }\end{array}\end{array}$ & 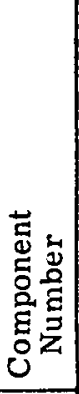 & 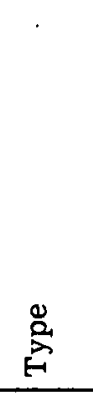 & 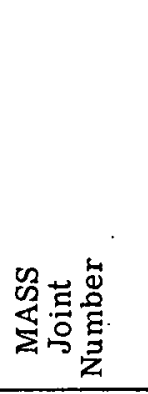 & 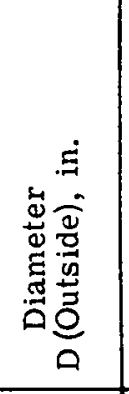 & 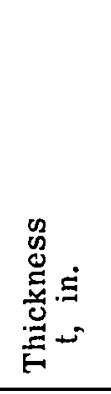 & 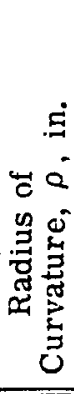 & $\frac{a}{2}$ & 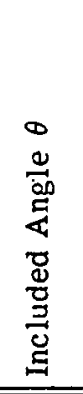 & 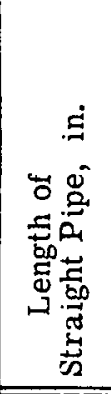 & 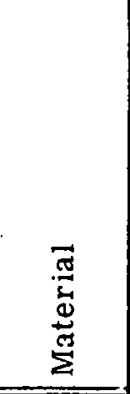 & 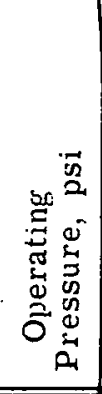 & 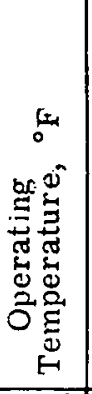 & 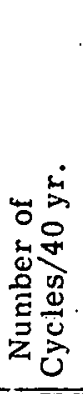 & 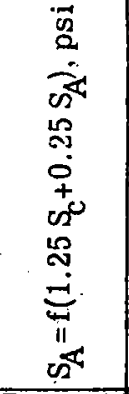 & 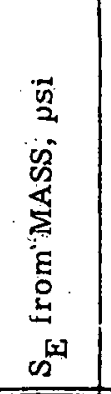 & $\begin{array}{c}\infty^{4} \\
\omega^{4} \\
n^{2}\end{array}$ & 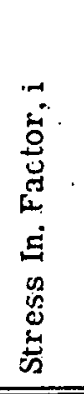 & 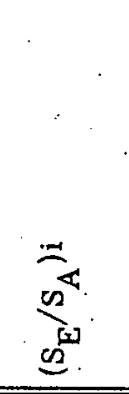 & 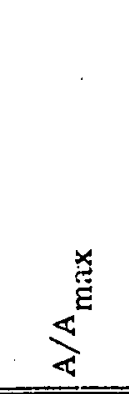 & 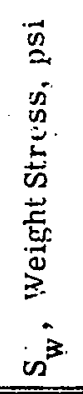 & 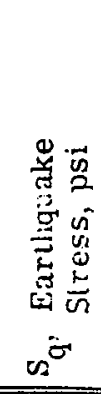 \\
\hline Butt Weld & & D-1 & 520 & & & & & & & & & & & & 2032 & 0.0774 & 1.0 & 0.0774 & & 180 & 1916 \\
\hline Isolation Valve & 20 & 4 & $520-521$ & 24.0 & 6.0 & & & & 57.0 & $\mathrm{~A} 106 \mathrm{C}$ & 1000 & 555 & 360 & 26,250 & 1383 & 0.0127 & & 0.0127 & 0.2495 & 137 & 777 \\
\hline $6 \mathrm{in}$. Branch of Tee 516 & 21 & 1 & $516-522$ & 6.624 & 0.432 & & & & 18.0 & A 106C & 1000 & 555 & 360 & 26,250 & 943 & 0.0359 & $1 . \overline{0}$ & 0.0359 & 0.0575 & 99 & 1443 \\
\hline Butt Weld & & D-1 & 522 & & & & & & & & & & & & 943 & 0.0359 & 1.0 & 0.0359 & & 97 & 842 \\
\hline Valve & 22 & 4 & $522-523$ & 6.624 & 1.6 & & & & 27.0 & A106C & 1000 & 555 & 360 & 26,250 & 463 & 0.0176 & & 0.0176 & 0.0203 & 45 & 388 \\
\hline Butt Weld & & D-1 & 523 & & & & & & & & & & & & 1005 & 0.0383 & 1.0 & 0.0383 & & 40 & 348 \\
\hline Straight & 23 & 1 & $523-524$ & 6.624 & 0.432 & & & & 9.0 & A106C & 1000 & 555 & 360 & 26.250 & 1026 d & 0.0391 & & 0,0391 & 0.0575 & 106 & 595 \\
\hline Butt Weld & & $D-1$ & 524 & & & & & & & & & & & & 1389 & 0.0529 & 1.0 & 0.0529 & & 110 & 615 \\
\hline Elbow & 24 & 2 & $524-525$ & 6.624 & 0.432 & 12 & 2.0 & $90^{\circ}$ & & A 106C & 1000 & 555 & 360 & 26,250 & 1389 & 0.0529 & & 0.0529 & 0.0575 & 144 & 800 \\
\hline Butt Weld & & D-1 & 525 & & & & & & & & & & & & 1268 & 0.0483 & 1.0. & 0,0483 & & 103 & J6z \\
\hline Straight & 25 & 1 & $525-526$ & 6. 624 & 0.432 & & & & 36.0 & A $106 \mathrm{C}$ & 1000 & 555 & 360 & 26,250 & 992 & 0.0378 & & $0.037 \mathrm{~d}$ & 0.0575 & $65 ?$ & 652 \\
\hline Bend & 26 & 3 & $526-527$ & 6.624 & 0.432 & 32 & 5.3 & $60^{\circ}$ & & $\mathrm{A} 106 \mathrm{C}$ & 1000 & 555 & 360 & 26,250 & 814 & $0.0310^{\circ}$ & & 0.0310 & 0.0575 & 89 & 552 \\
\hline Straight & 27 & 1 & $527-528$ & 6.624 & 0.432 & & & & 73.2 & $\mathrm{~A} 106 \mathrm{C}$ & 1000 & 555 & 360 & 20.250 & 660 & 0.0251 & & 0.0251 & 0.0575 & 249 & 870 \\
\hline Bend & 28 & 3 & $528-529$ & 6.624 & 0.432 & 31 & 5.3 & $90^{\circ}$ & & $\mathrm{A} 106 \mathrm{C}$ & 1000 & 555 & 360 & 26,250 & 478 & 0.0182 & & 0.0182 & 0.0575 & 174 & 934 \\
\hline Straight & 29 & 1 & $529-530$ & 6.624 & 0.432 & & & & 25.7 & A 106C & 1000 & 555 & 360 & 26,250 & 328 & 0,0125 & & 0.0125 & 0.0575 & 818 & 1090 \\
\hline Bend & 30 & 3 & $530-531$ & 6.624 & 0.432 & 12 & 2.0 & $90^{\circ}$ & & $\mathrm{A} 106 \mathrm{C}$ & 1000 & 555 & 360 & 26,250 & 345 & 0.0131 & & 0.0131 & 0.0575 & 134 & 2427 \\
\hline Straight & 31 & 1 & $531-532$ & 6.624 & 0.432 & & & & 173.7 & A 1 106C & 1000 & 555 & 360 & 26,250 & 636 & 0.0242 & & 0.0242 & 0.0575 & 161 & 2663 \\
\hline \multicolumn{22}{|l|}{ Model 1 - Steam Vent Line } \\
\hline $\begin{array}{l}\text { Pressure Vessel } \\
\text { Nozzle Weld }\end{array}$ & & D-1 & 5 & & & & & & & & & & & & 265 & 0.0101 & 1.0 & 0.0101 & & 6 & 390 \\
\hline .Straight & 51 & 1 & $551-552$ & 4.5 & 0.337 & & & & 30.0 & A $106 \mathrm{C}$ & 1000 & 551 & 360 & 26,250 & 265 & 0.0101 & & 0.1010 & 0.0254 & 5 & 270 \\
\hline $4 \times 2$ Reducer & & D-6 & 552 & & & & & & & & & & & & 1498 & 0.0571 & 1.0 & 0.0571 & & 32 & 1579 \\
\hline Elbow & 52 & 2 & $552-553$ & 2.376 & 0.218 & 6 & 3.0 & $90^{\circ}$ & & A106C & 1000 & 551 & 360 & 26,250 & 1498 & 0.0571 & & 0.0571 & 0.0065 & 207 & 1629 \\
\hline Socket Weld & & $D-1 a$ & 553 & & & & & & & & & & & & 1423 & 0.0542 & 1.3 & 0.0705 & & 207 & 1629 \\
\hline iStraight & 53 & 1 & $553-554$ & 2.376 & 0.218 & & & & 161.9 & A $106 \mathrm{C}$ & 1000 & $55 \mathrm{i}$ & 360 & 26,250 & 1423 & 0.0542 & & 0.0542 & 0.0065 & 419 & 1265 \\
\hline Socket Weld & & $D-1 a$ & 554 & & & & & & & & & & & & 340 & 0.0130 & 1.3 & 0.0169 & & 419 & 1265 \\
\hline :Elbow & 54 & 2 & $554-555$ & 2.376 & 0.218 & 6 & 3.0 & $90^{\circ}$ & & A106C & 1000 & 551 & 360 & 26,250 & 395 & 0.0150 & & 0.0150 & 0.0065 & 82 & 1274 \\
\hline Socket Weld & & D-1a & 555 & & & & & & & & & & & & 395 & 0.0150 & 1.3 & 0.0195 & & 82 & 1274 \\
\hline :Straight & 55 & 1 & $555-556$ & 2.376 & 0.218 & & & & 142.0 & A106C & 1000 & 551 & 360 & 26,250 & 395 & 0.0150 & & 0.0150 & 0.0065 & 71 & 1576 \\
\hline Flange & & D-5 & & & & & & & & & & & & & 157 & 0.0060 & 1.0 & 0.0060 & & 71 & 1576 \\
\hline iStraight & 56 & 1 & $556-557$ & 2.376 & 0.218 & & & & 64.0 & $\mathrm{~A} 106 \mathrm{C}$ & 10.00 & 551 & 360 & 26,250 & 157 & 0.0060 & & 0.0060 & 0.0065 & 66 & 2476 \\
\hline Socket Weld & & D-1a & 557 & & & & & & & & & & & & $: 50$ & 0.0019 & 1.3 & 0,0025 & & 66 & 2476 \\
\hline :Elbow & 57 & 2 & $557-558$ & 2.376 & 0.218 & 6 & 3.0 & $90^{\circ}$ & & A 106C & 1000 & 551 & 360 & 26,250 & 103 & 0.0039 & & 0.0039 & 0.0065 & 146 & 2765 \\
\hline Socket Weld & & D-1a & 558 & & & & & & & & & & & & 103 & 0.0039 & 1.3 & 0.0051 & & 146 & 2765 \\
\hline :Straight & 58 & 1 & 558-559 & 2.376 & 0.218 & & & & 56.4 & $\mathrm{~A} 106 \mathrm{C}$ & 1000 & 551 & 360 & 26,250 & 693 & 0.0264 & & 0.0264 & 0.0065 & 141 & 4177 \\
\hline Socket Weld & & D-1a & 559 & & & & & & & & & & & & 693 & 0.0264 & 1.3 & 0.0343 & & 141 & 4177 \\
\hline
\end{tabular}




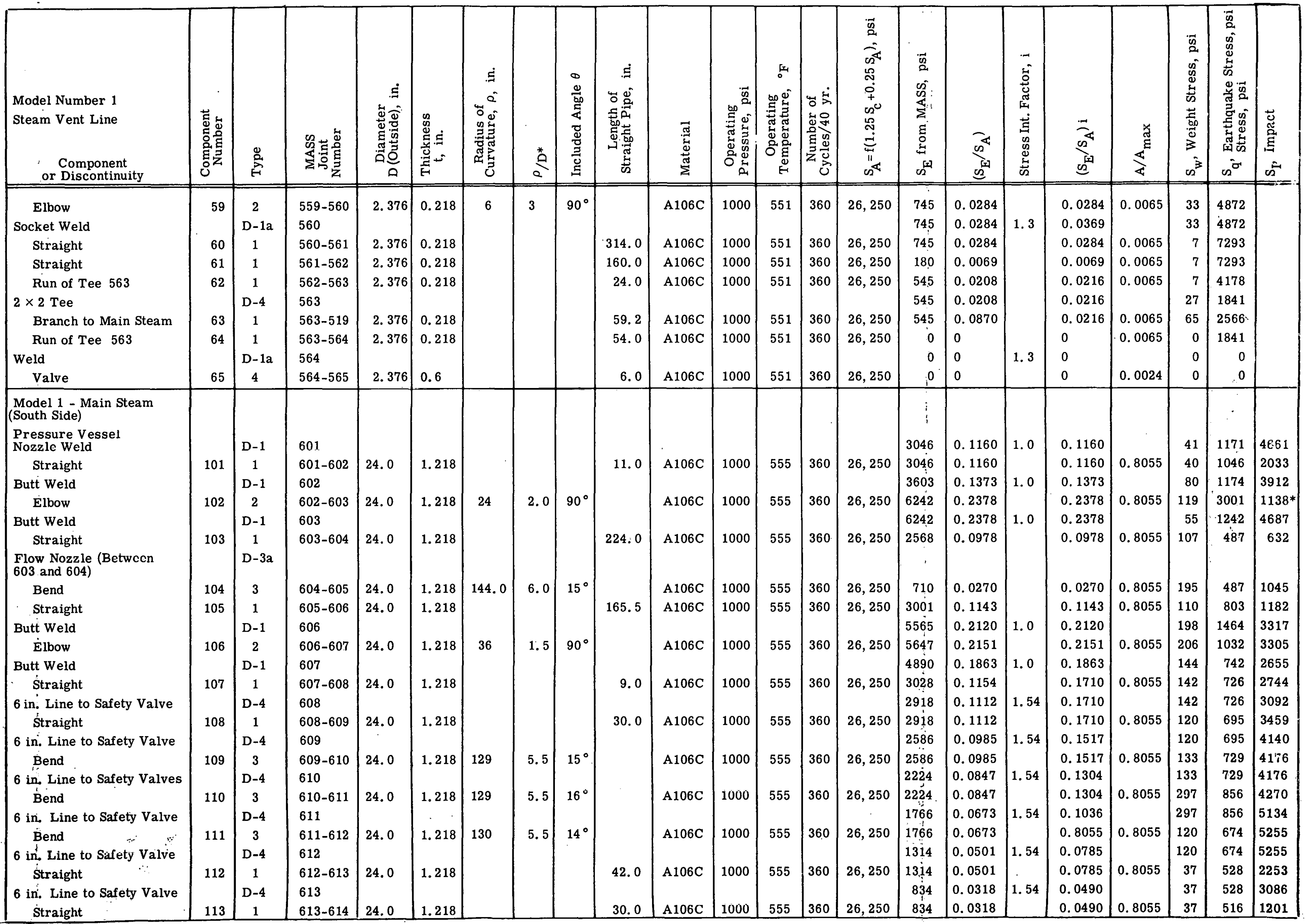




\begin{tabular}{|c|c|c|c|c|c|c|c|c|c|c|c|c|c|c|c|c|c|c|c|c|c|c|}
\hline $\begin{array}{l}\text { Model Number 1 } \\
\text { Main Steam (South Side) } \\
\text { * Steam Relief Line } \\
\text { (South Side) } \\
\text { Component } \\
\text { or Discontinuity } \\
\end{array}$ & 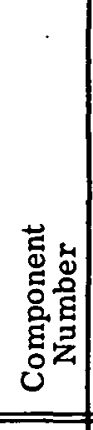 & 产 & 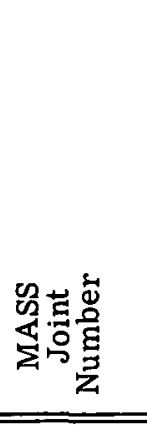 & 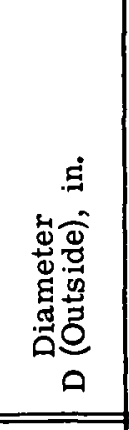 & 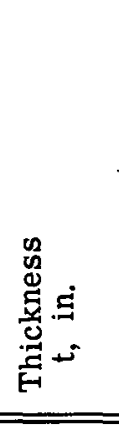 & 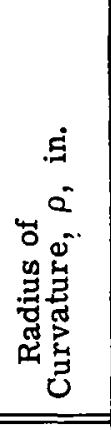 & $\stackrel{2}{\stackrel{*}{Q}}$ & 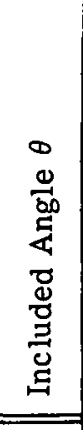 & 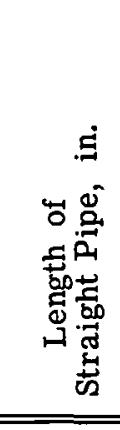 & 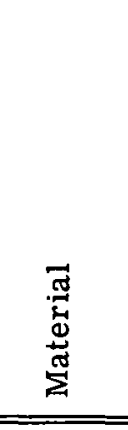 & 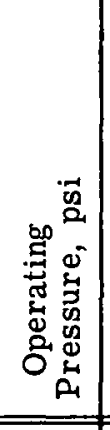 & 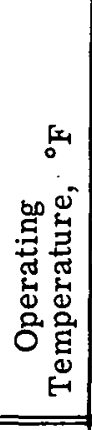 & 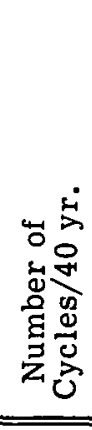 & 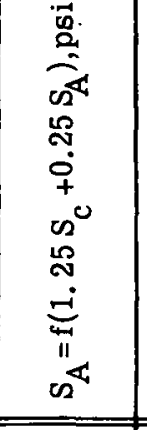 & 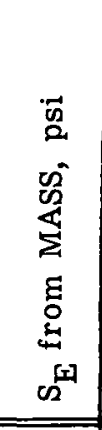 & $\begin{array}{c}2^{4} \\
0^{4} \\
0^{4}\end{array}$ & 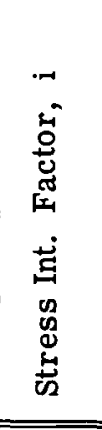 & 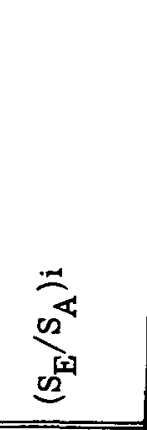 & $\overleftarrow{4}_{4}^{\stackrel{x}{\sharp}}$ & 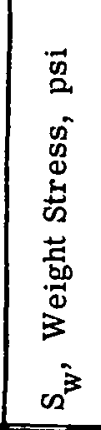 & 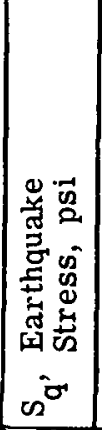 & 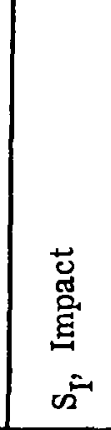 \\
\hline 6 in. Line to Safety Valve & & D-4 & 614 & & & & & & & & & & & & 825 & 0.0314 & 1.54 & 0.0480 & & 77 & 516 & 1201 \\
\hline Straight & 114 & 1 & $614-615$ & 24.0 & 1.218 & & & & 30.0 & A106C & 1000 & 555 & 360 & 26,250 & 1124 & 0.0428 & & 0.0480 & 0.8055 & 77 & 512 & 1858 \\
\hline 6 in. Line to Safety Valve & & D-4 & & & & & & & & & & & & & 1124 & 0.0428 & 1.54 & 0.0659 & & 72 & 512 & 1152 \\
\hline Straight & 115 & 1 & $615-616$ & 24.0 & 1.218 & & & & 30.0 & A106C & 1000 & 555 & 360 & 26,250 & 1564 & 0.0596 & & 0.0659 & 0.8055 & 72 & 524 & 3050 \\
\hline 6 in. Line to Relief Valve & & D-4 & 616 & & & & & & & & & & & & 1564 & 0.0596 & 1.54 & 0.0918 & & 34 & 515 & 3056 \\
\hline Straight & 116 & 1 & $616-617$ & 24.0 & 1.218 & & & & 12.0 & A106C & 1000 & 555 & 360 & 26,250 & 1743 & 0.0664 & & 0.0918 & 0.8055 & 33 & 493 & 947 \\
\hline Butt Weld & & D-1 & 617 & & & & & & & & & & & & 3034 & 0.1156 & 1.0 & 0.1156 & & 35 & 572 & 1205 \\
\hline Elbow & 117 & 2 & $617-618$ & 24.0 & 1.218 & 35.9 & 1.5 & $90^{\circ}$ & & $\mathrm{A} 106 \mathrm{C}$ & 1000 & 555 & 360 & 26,250 & 3603 & 0.1373 & & 0.1373 & 0.8055 & 64 & 1784 & 14720 \\
\hline Butt Weld & & $D-1$ & & & & & & & & & & & & & 3514 & 0.1330 & 1.0 & 0.1339 & & 87 & 997 & 7928 \\
\hline Straight & 118 & 1 & $618-619$ & 24.0 & 1.218 & & & & 204.0 & A106C & 1000 & 555 & 360 & 26,250 & 1942 & 0.0739 & & 0.0739 & 0.8055 & 57 & 1206 & 7277 \\
\hline Butt Weld & & $D-1$ & & & & & & & & & & & & & 2309 & 0.0880 & 1.0 & 0.0880 & & 46 & 2849 & 17690 \\
\hline Elbow & 119 & 2 & $619-620$ & 24.0 & 1.218 & 24.0 & 1.0 & $90^{\circ}$ & - & $\mathrm{A} 106 \mathrm{C}$ & 1000 & 555 & 360 & 26,250 & 2670 & 0.1017 & & 0.1017 & 0.8055 & 74 & 1508 & 8942 \\
\hline Butt Weld & & D-1 & & & & & & & & & & & & & 2050 & 0.0781 & 1.0 & 0.0781 & & 197 & 440 & 2742 \\
\hline Isolation Valve & 120 & 4 & $620-621$ & 24.0 & 1.218 & & & & 57.0 & A106C & 1000 & 555 & 360 & 26,250 & 338 & 0.0129 & & 0.0129 & 0.2495 & 144 & 733 & 4245 \\
\hline * Straight & 121 & 1 & $616-622$ & 6.624 & 0.432 & & & & 18.0 & A106C & 1000 & 555 & 360 & 26,250 & 803 & 0.0306 & & 0.0306 & 0.0575 & 211 & 3817. & 255 \\
\hline Butt Weld & & D-1 & 622 & & & & & & & & & & & & 803 & 0.0306 & 1.0 & 0.0306 & & 211 & 3629 & 118 \\
\hline Valve & 122 & 4 & $622-623$ & 6.624 & 1.6 & & & & 27.0 & A106C & 1000 & 555 & 360 & 26,250 & 432 & 0.0165 & & 0.0165 & 0.0575 & 97 & 1698 & 118 \\
\hline Butt Weld & & D-1 & & & & & & & & & & & & & 937 & 0.0357 & 1.0 & 0.0357 & & 208 & 3682 & 256 \\
\hline Straight & 123 & 1 & $623-624$ & 6.624 & 0.432 & & & & 9.0 & $\mathrm{~A} 106 \mathrm{C}$ & 1000 & 555 & 360 & 26,250 & 982 & 0.0374 & & 0.0374 & 0.0575 & 208 & 3752 & 256 \\
\hline Butt Weld & & D-1 & 624 & & & & & & & & & & & & 1301 & 0.0495 & 1.0 & 0.0495 & & 282 & 3867 & 348 \\
\hline Elbow & 124 & 2 & $624-625$ & 6.624 & 0.432 & 12.0 & 2.0 & $90^{\circ}$ & & A106C & 1000 & 555 & 360 & 26,250 & 1301 & 0.0495 & & 0.0495 & 0.0575 & 297 & 4558 & 259 \\
\hline Butt Weld & & $D-1$ & 625 & & & & & & & & & & & & 1202 & 0.0458 & 1.0 & 0.0458 & & 253 & 3498 & 192 \\
\hline Straight & 125 & 1 & $625-626$ & 6.624 & 0.432 & & & & 36.0 & A 106C & 1000 & 555 & 360 & 26,250 & 1015 & 0.0387 & & 0.0387 & 0.0575 & 1276 & 2617 & 29 \\
\hline Bend & 126 & 3 & $626-627$ & 6.624 & 0.432 & 32.0 & 5.3 & $60^{\circ}$ & & A 106C & 1000 & 555 & 360 & 26,250 & 946 & 0.0360 & & 0.0360 & 0.0575 & 524 & 1847 & 28 \\
\hline Straight & 127 & 1 & $627-628$ & 6.624 & 0.432 & & & & 73.2 & $\mathrm{~A} 106 \mathrm{C}$ & 1000 & 555 & 360 & 26,250 & 823 & 0.0314 & & 0.0314 & 0.0575 & 189 & 1567 & 26 \\
\hline Bend & 128 & 3 & $628-629$ & 6.624 & 0.432 & 31.1 & 5.2 & $90^{\circ}$ & & A $106 \mathrm{C}$ & 1000 & 555 & 360 & 26,250 & 489 & 0.0186 & & 0.0186 & 0.0575 & 87 & 880 & 27 \\
\hline Ștraight & 129 & 1 & $629-630$ & 6.624 & 0.432 & & & & 64.7 & $\mathrm{~A} 106 \mathrm{C}$ & 1000 & 555 & 360 & 26,250 & 286 & 0.0109 & & 0.0109 & 0.0575 & 1111 & 1544 & 27 \\
\hline Bend & 13 & 3 & $630-631$ & 6.624 & 0.432 & 12.0 & 2.0 & $90^{\circ}$ & & $\mathrm{A} 106 \mathrm{C}$ & 1000 & 555 & 360 & 26,250 & 342 & 0.0130 & & 0.0130 & 0.0575 & 1506 & 397 & 41 \\
\hline Straight & 131 & 1 & $631-632$ & 6.624 & 0.432 & & & & 173.7 & A106C & 1000 & 555 & 360 & 26,250 & 897 & 0.0342 & & 0.0342 & 0.0575 & 0 & I & 0 \\
\hline
\end{tabular}

*Note: Safety valves are oriented such that alternate valves discharge in opposite directions so as to counterbalance the reaction forces. The impact stresses shown above
assumed that four valves discharging in the same direction functioned properly while the four counterbalancing valves did not function. This is the worst case and would occur with low probability. Operation of one valve occurs with probability $\sim 1$ and results in stresses $\cong 1 / 4$ the values shown above. 


\begin{tabular}{|c|c|c|c|c|c|c|c|c|c|c|c|c|c|c|c|c|c|c|c|c|c|}
\hline $\begin{array}{l}\text { Model Number } 1 \\
\text { Reactor Drain Pipe } \\
\begin{array}{c}\text { Component } \\
\text { or Discontinuity } \\
\end{array}\end{array}$ & 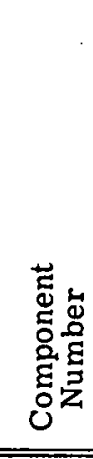 & 产 & 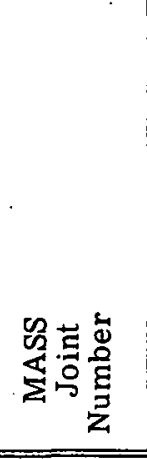 & 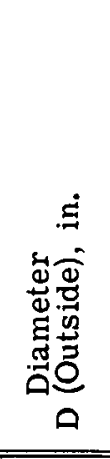 & 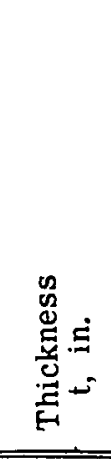 & 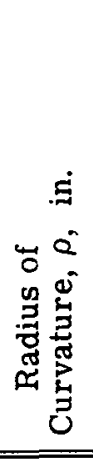 & $\stackrel{e}{E}$ & 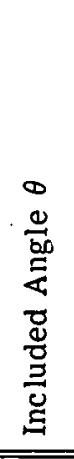 & 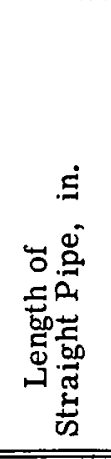 & 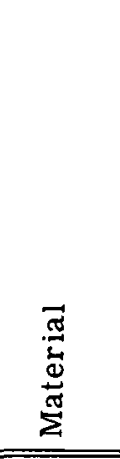 & 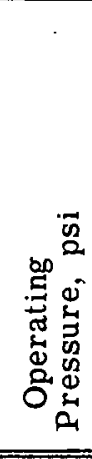 & 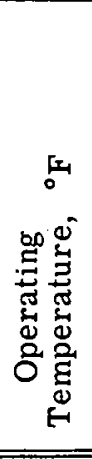 & 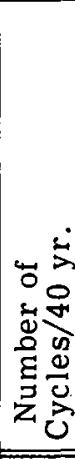 & 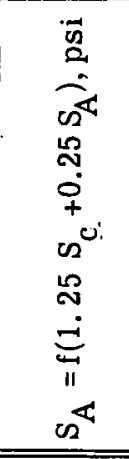 & 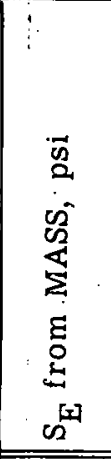 & $\begin{array}{c}\underbrace{4} \\
\omega^{4} \\
0\end{array}$ & 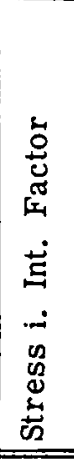 & 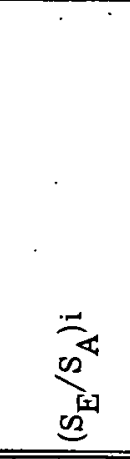 & 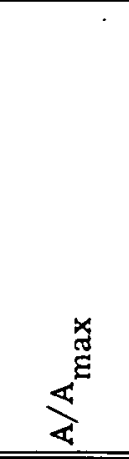 & 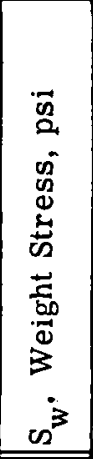 & 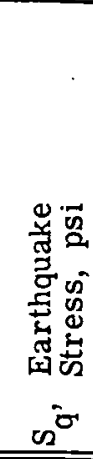 \\
\hline $\begin{array}{l}\text { Pressure Vessel } \\
\text { Nozzle Weld }\end{array}$ & & D-1a & & & & & & & & Seam & & & & & 9219 & 0.3532 & 1.3 & 0.4592 & & 81 & 2046 \\
\hline Straight & 151 & 1 & $651-652$ & 2.374 & 0.218 & & & & 16.0 & $\begin{array}{l}\text { les } \\
30\end{array}$ & 1000 & 551 & 500 & 26.100 & 9794 & 0.3752 & & 0.3752 & 0.0065 & 77 & 1696 \\
\hline Weld & & D-1a & & & & & & & & & & & & & 16940 & 0.6490 & 1.3 & 0.8437 & & 134 & 1836 \\
\hline Elbow & 152 & 2 & $652-653$ & 2.374 & 0.218 & 2.0 & 1.0 & $90^{\circ}$ & & 304 & 1000 & 551 & 500 & 26.100 & 16940 & 0.6490 & & 0.6490 & 0.0065 & 44 & 2695 \\
\hline Weld & & D-1a & & & & & & & & & & & & & 16940 & 0.6490 & 1.3 & 0.8224 & & 25 & 1594 \\
\hline Straight & 153 & 1 & $653-654$ & 2.374 & 0.218 & & & & 95.0 & 304 & 1000 & 551 & 500 & 26,100 & 9545 & 0.3657 & & 0.3657 & 0.0065 & 70 & 1753 \\
\hline Weld & & D-1a & 654 & & & & & & & & & & & & 9801 & 0.3755 & 1.3 & $0: 4882$ & & 121 & 3033 \\
\hline Elbow: & 154 & 2 & $654-655$ & 2.374 & 0.218 & 2.0 & 1.0 & $90^{\circ}$ & & 304 & 1000 & 551 & 500 & 26,100 & 10230 & 0.3920 & & 0.3920 & 0.0065 & 52 & 3000 \\
\hline Weld & & D-1a & & & & & & & & & & & & & 10230 & 0.3920 & 1.3 & 0.5096 & & 30 & 1734 \\
\hline Straight & 155 & 1 & $655-656$ & 2.374 & 0.218 & & & & 120.3 & 304 & 1000 & 551 & 500 & 26.100 & 5913 & 0.2266 & & 0.2266 & 0.0065 & 5 & 2493 \\
\hline Weld. & & $D-1 a$ & & & & & & & & & & & & & 2759 & 0.1057 & 1.3 & 0.1374 & & 8 & 4313 \\
\hline Elbow & 156 & 2 & $656-657$ & 2.374 & 0.218 & 2.0 & 1.0 & $45^{\circ}$ & & 304 & 1000 & 551 & 500 & 26,100 & 2833 & 0.1085 & & 0.1085 & 0.0065 & 6 & 4220 \\
\hline Weld & & D-1a & & & & & & & & & & & & & 2833 & 0.1085 & 1.3 & 0.1411 & & 4 & 2439 \\
\hline Straight & 157 & 1 & $657-658$ & 2.374 & 0.218 & & & & 15.3 & 304 & 1000 & 551 & 500 & 26.100 & 2976 & 0.1140 & & 0.1140 & 0.0065 & 79 & 1642 \\
\hline Weld & & D-1a & & & & & & & & & & & & & 5150 & 0.1973 & 1.3 & 0.2565 & & 137 & 2450 \\
\hline Elbow & 158 & 2 & $658-659$ & 2. 374 & 0.218 & 2.0 & 1.0 & $45^{\circ}$ & & 304 & 1000 & 551 & 500 & 26,100 & 5229 & 0.2003 & & 0.2003 & 0.0065 & 34 & 2889 \\
\hline Weld & & D-1a & 659 & & & & & & & & & & & & 5224 & 0.2002 & 1.3 & 0.2603 & & 20 & 1678 \\
\hline Stralght & 159 & $\because 1$ & $659-660$ & 2. 374 & 0.218 & & & & 196.0 & 304 & 1000 & 551 & 500 & 26,100 & 4032 & 0.1545 & & 0.1545 & 0.0065 & 22 & 2104 \\
\hline Weld & & D-1a & 660 & & & & & & & & & & & & 4032 & 0.1545 & 1.3 & 0.2009 & & 13 & 1244 \\
\hline Valve & 160 & 4 & $660-661$ & 2. 374 & 0.218 & & & & 4.0 & 304 & 1000 & 551 & 500 & 26,100 & 2469 & 0.0946 & & 0.0946 & 0.0024 & 13 & 1443 \\
\hline $\begin{array}{l}\text { Model Number } 2 \\
\text { Core Spray (Line 1) }\end{array}$ & & $\because$ & & & & & & & & & & & & & & & & & & & \\
\hline $\begin{array}{l}\text { Pressure Vessel } \\
\text { Nozzle Weld }\end{array}$ & & D-1 & 1 & & & & & & & & & & & & 478 & 0.0174 & 1.0 & 0.0174 & & 2306 & 3826 \\
\hline Straight & 201 & 1 & $1-2$ & 6.624 & 0.432 & & & & 30.9 & 304 & 1000 & 146 & 370 & 27,400 & 478 & 0.0174 & & 0.0174 & 0.0575 & 350 & 3139 \\
\hline Weld & & $D-1$ & 2 & & & & & & & & & & & & 613 & 0,0224 & 1.0 & 0.0224 & & 621 & 4678 \\
\hline Elbow & 202 & .2 & $2-3$ & 6. 624 & 0,432 & 8 & 1.3 & $90^{\circ}$ & & $=304$ & 1000 & 146 & 370 & 27,400 & 741 & 0.0270 & & 0.0270 & 0.0575 & 196 & 4687 \\
\hline Weld & & D-1. & 3 & & & & & & & & & & & & 741 & 0.0270 & 1.0 & 0.0270 & & 128 & 4687 \\
\hline Straight & 203 & 1 & $3-4$ & 6.624 & 0,432 & & & & 81.0 & 304 & 1000 & $146^{\circ}$ & 370. & 27,400 & 638 & 0.0233 & & 0.0233 & 0.0575 & 85 & 1436 \\
\hline Weld & & $\mathrm{D}-1$ & 4 & & & & & & & & & & & & 638 & 0.0233 & 1.0 & 0.0233 & & 85 & 1436 \\
\hline
\end{tabular}




\begin{tabular}{|c|c|c|c|c|c|c|c|c|c|c|c|c|c|c|c|c|c|c|c|c|c|}
\hline $\begin{array}{c}\vdots \\
\text { Model Number 2 } \\
\text { Core Spray (Line 1) } \\
\text { (Continued) } \\
\vdots \\
\text { Component } \\
\text { or Discontinuity }\end{array}$ & 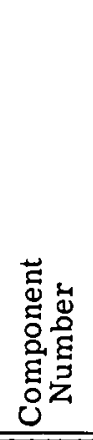 & 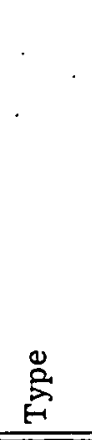 & 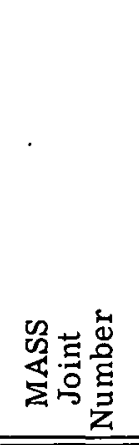 & 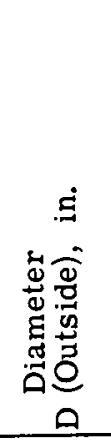 & 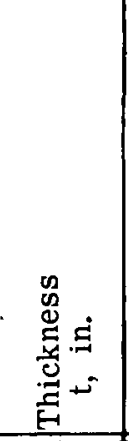 & 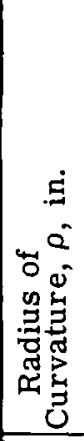 & $\stackrel{+}{a}$ & 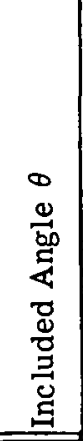 & 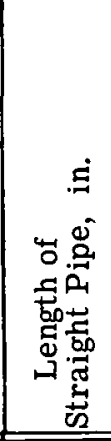 & 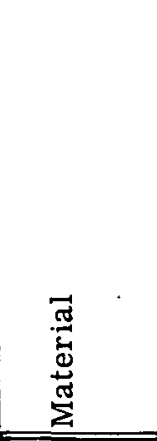 & 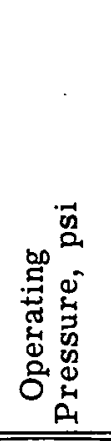 & 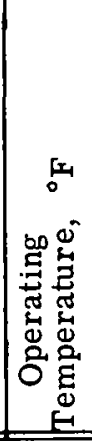 & 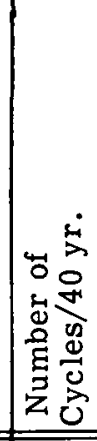 & 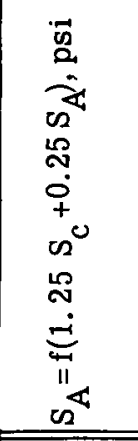 & 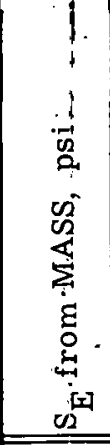 & $\begin{array}{l}i^{4} \\
n^{4 / 2} \\
\end{array}$ & 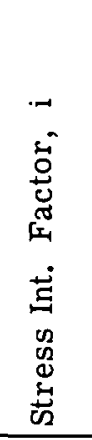 & 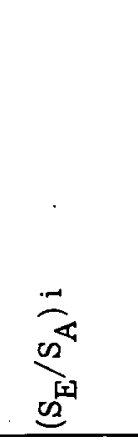 & 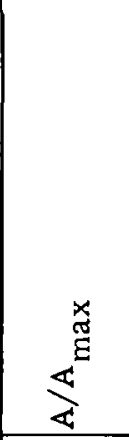 & 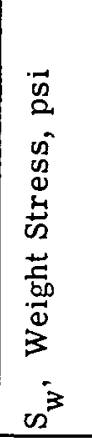 & 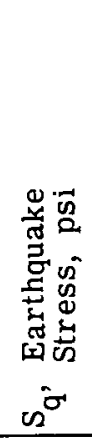 \\
\hline Elbow & 204 & 2 & $4-5$ & 6.624 & 0.432 & 40 & 6.6 & $90^{\circ}$ & & $\begin{array}{c}\text { Seamless } \\
304\end{array}$ & 1000 & 146 & 370 & 27,400 & $\begin{array}{ll}1 \\
698\end{array}$ & $0.0255 \mid$ & & 0.0255 & 0.0575 & 572 & 2028 \\
\hline Weld' & 204 & $D-1$ & 5 & & & & & & & & 1000 & 170 & . & 0,700 & 698 & 0.0255 & 1.0 & 0.0255 & & 572 & 2028 \\
\hline Straight & 205 & 1 & $5-6$ & 6.624 & 0.432 & & & & 8.0 & 304 & 1000 & 146 & 370 & 27,400 & 698 & 0.0255 & & 0.0255 & 0.0575 & 591 & 2085 \\
\hline Bend & 206 & 3 & $6-7$ & 6.624 & 0.432 & 40 & 6.6 & $45^{\circ}$ & & 304 & 1000 & 146 & 370 & 27,400 & 695 & 0.0254 & & 0.0254 & 0.0575 & 591 & 2097 \\
\hline Straight & 207 & 1 & $7-8$ & 6.624 & 0.432 & & & & 59.1 & 304 & 1000 & 146 & 370 & 27,400 & 659 & 0.0241 & & 0.0241 & 0.0575 & 472 & 2097 \\
\hline Hanger Location & & $\mathrm{D}-2$ & 8 & & & & & & & & & & & & 609 & 0.0222 & 1.0 & 0.0222 & & 933 & 1728 \\
\hline Bend & 208 & 3 & $8-9$ & 6.624 & 0.432 & 40 & 6.6 & $45^{\circ}$ & & 304 & 1000 & 146 & 370 & 27,400 & 609 & $|0.0222|$ & & 0.0222 & 0.0575 & 100 & 1728 \\
\hline Straight & 209 & 1 & $9-10$ & 6.624 & 0.432 & & & & 138.0 & 304 & 1000 & 146 & 370 & 27,400 & 576 & $0.0210 \mid$ & & 0.0210 & 0.0575 & 476 & 1409 \\
\hline Bend & 210 & 3 & $10-11$ & 6.624 & 0.432 & 40 & 6.6 & $45^{\circ}$ & & 304 & 1000 & 146 & 370 & $27 ; 400$ & 513 & 0.0187 & & 0.0187 & 0.0575 & 476 & 1347 \\
\hline Hanger Location & & $\mathrm{D}-2$ & 11 & & & & & & & & & & & & 497 & 0.0181 & 1.0 & 0.0181 & & 418 & 1347 \\
\hline Straight & 211 & 1 & $11-12$ & 6.624 & 0.432 & & & & 145.0 & 304 & 1000 & 146 & 370 & 27,400 & 552 & 0.0201 & & 0.0201 & 0.0575 & 454 & 1598 \\
\hline Bend & 212 & 3 & $12-13$ & 6.624 & 0.432 & 40 & 6.6 & $45^{\circ}$ & & 304 & 1000 & 146 & 370 & 27,400 & 600 & 0.0219 & & 0.0219 & $0: 0575$ & 454 & 1598 \\
\hline Hanger Location & & $\mathrm{D}-2$ & 13 & & & & & & & & & & & & 600 & 0.0219 & 1.0 & 0.0219 & & 371 & 1056 \\
\hline Straight & 213 & 1 & $13-14$ & 6.624 & 0.432 & & & & 120.6 & 304 & 1000 & 146 & 370 & 27,400 & 885 & 0.0323 & & 0.0323 & 0.0575 & 542 & 2038 \\
\hline Bènd & 214 & 3 & $14-15$ & 6.624 & 0.432 & 41 & 6.8 & $66^{\circ}$ & & 304 & 1000 & 146 & 370 & 27,400 & 1061 & 0.0387 & & 0.0387 & 0.0575 & 542 & 3078 \\
\hline Weld & & $D-1$ & 15 & & & & & & & & & & & & \begin{tabular}{|l}
1061 \\
1061
\end{tabular} & 0.0387 & 1.0 & 0.0387 & & 570 & 3078 \\
\hline Isolation Valve & 215 & 4 & $15-16$ & 6.624 & 0.432 & & & & 30.0 & 304 & 1000 & 146 & 370 & 27,400 & 531 & 0.0194 & & 0.0194 & 0.0575 & 1153 & 1489 \\
\hline $\begin{array}{l}\text { Model Number } 2 \\
\text { Core Spray - Line } 2\end{array}$ & & & & & & & & & & & & & & & & & & & & & \\
\hline $\begin{array}{l}\text { Pressure Vessel } \\
\text { Nozzle Weld }\end{array}$ & & $D-1$ & 21 & 6.624 & 0.432 & & & & 30.9 & 304 & 1000 & 146 & 370 & 27,400 & 17240 & 0.6292 & 1.0 & 0.0692 & & 3654 & 892 \\
\hline straight & 221 & 1 & $21-22$ & 6.624 & 0.432 & & & & 30.9 & 304 & 1000 & 146 & 370 & 27,400 & 17240 & 0.6292 & & 0.0692 & 0.0575 & 77 & 677 \\
\hline Weld' & & $D-1$ & 22 & & & & & & & & & & & & 388 & 0.0142 & 1.0 & 0.0142 & & 110 & 757 \\
\hline Elbow & 222 & 2 & $22-23$ & 6.624 & 0.432 & 8 & 1.3 & $90^{\circ}$ & & 304 & 1000 & 146 & 370 & 27,400 & 5344 & 0.1950 & & 0.1950 & 0.0575 & 1356 & 890 \\
\hline Weld & & $D-1$ & 23 & & & & & & & & & & & & 53 & 0.1950 & 1.0 & 0.1950 & & 762 & 593 \\
\hline Straight & 223 & 1 & $23-24$ & 6.624 & 0.432 & & & & 51.0 & 304 & 1000 & 146 & 370 & 27,400 & 6443 & 0.2351 & & 0.2351 & 0.0575 & 381 & 726 \\
\hline Weld & & D-1 & 24 & & & & & & & & & & & & 6443 & 0.2351 & 1.0 & 0.2351 & & 381 & 726 \\
\hline Válve & 224 & 4 & $24-25$ & 6.624 & 0.432 & & & & 30.0 & 304 & 1000 & 146 & 370 & 27,400 & 11990 & 0.4376 & & 0.4376 & 0.0575 & 157 & 759 \\
\hline Weld & & D-1 & 25 & & & & & & & & & & & & 11990 & 0.4376 & 1.0 & 0.4376 & & 157 & 759 \\
\hline Bend & 225 & 3 & $25-26$ & 6.624 & 0.432 & 40 & 6.6 & $90^{\circ}$ & & 304 & 1000 & 146 & 370 & 27,400 & 11990 & 0.4376 & & 0.4376 & 0.0575 & 173 & 244 \\
\hline Straight & 226 & 1 & $26-27$ & 6.624 & 0.432 & & & & 43.8 & 304 & 1000 & 146 & 370 & 27,400 & 27450 & 1.0020 & & 1.0020 & 0.0575 & 298 & 286 \\
\hline Weld & & D-1 & 27 & & & & & & & & & & & & 27450 & 1.0020 & 1.0 & 1.0020 & & 138 & 650 \\
\hline Isolation Valve & 227 & 4 & $27-28$ & 6.624 & 0.432 & & & & 30.0 & 304 & 1000 & 146 & 370 & 27,400 & 20390 & 0.7442 & & 0.7442 & 0.0575 & 878 & 1033 \\
\hline
\end{tabular}




\begin{tabular}{|c|c|c|c|c|c|c|c|c|c|c|c|c|c|c|c|c|c|c|c|c|c|}
\hline $\begin{array}{l}\text { Model Number } 2 \\
\text { Feced Water (South Side) } \\
\text { Component } \\
\text { or Discontinuily }\end{array}$ & 倍 & 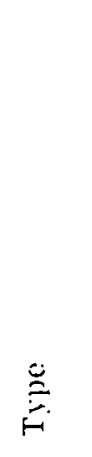 & 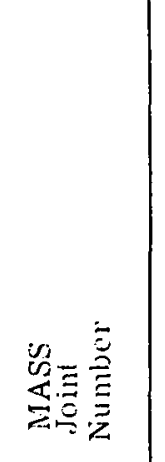 & 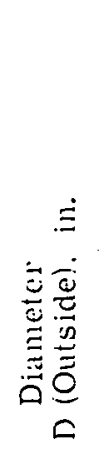 & 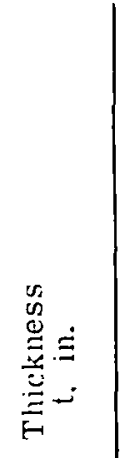 & 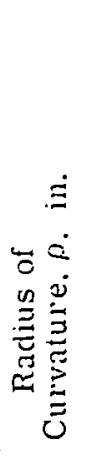 & $\stackrel{*}{=}$ & 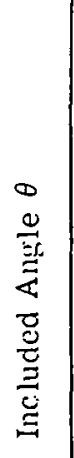 & 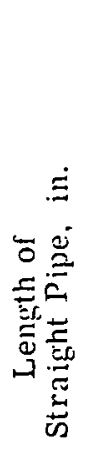 & 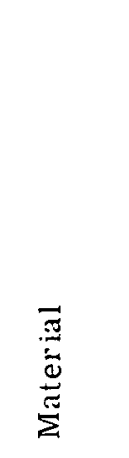 & 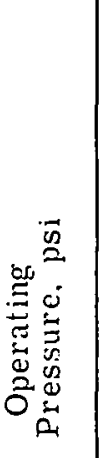 & 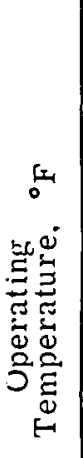 & 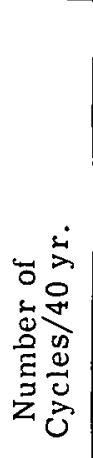 & 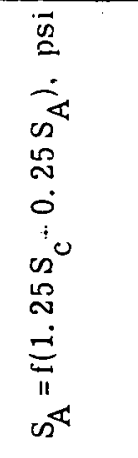 & 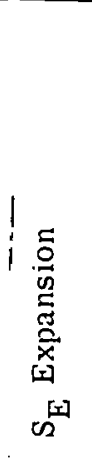 & $\underbrace{}_{\substack{w^{4} \\
w^{4}}}$ & 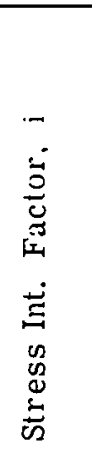 & $\underbrace{\infty}$ & 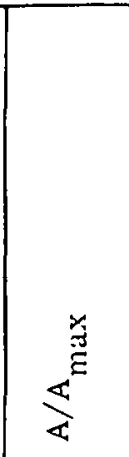 & 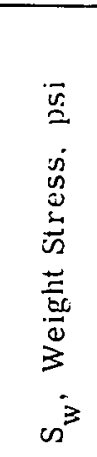 & 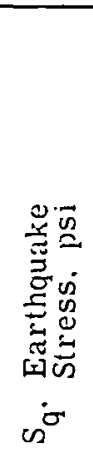 \\
\hline $\begin{array}{l}\text { Pressure Vessel } \\
\text { Nozzle Weld }\end{array}$ & & $D-1$ & 701 & & & & & & & & & & & & 892 & 0.0340 & 1.0 & .0340 & & 1478 & 2548 \\
\hline Slraighth & 301 & 1 & $701-702$ & 10.75 & 0.593 & & & & 18.8 & $\mathrm{~A} 106 \mathrm{C}$ & 1260 & 325 & 440 & 26. 250 & 892 & 0.0340 & & 0.0340 & 0.1585 & 564 & 2489 \\
\hline weld & & $D-1$ & 702 & & & & & & & & & & & & 984 & 0.0375 & 1.0 & 0.0375 & & 976 & 2876 \\
\hline Ellow & 302 & 2 & $702-703$ & 10.75 & 0.593 & 15 & 1.5 & $90^{\circ}$ & & $\mathrm{A} 106 \mathrm{C}$ & 1260 & 325 & 440 & 26.250 & 1270 & 0.0484 & & 0.0484 & 0.1585 & 463 & 3800 \\
\hline Weld & & D-1 & 703 & & & & & & & & & & & & 1270 & 0.0484 & 1.0 & 0.0484 & & 256 & 3800 \\
\hline Straight & 303 & 1 & 703-704 & 10.75 & 0.593 & & & & 130.9 & $\mathrm{~A} 106 \mathrm{C}$ & 1260 & 325 & 440 & 26.250 & 704 & 0.0268 & & 0.0268 & 0.1585 & 290 & 2048 \\
\hline Benel & 304 & 3 & $704-705$ & 10.75 & 0.593 & 15 & 1.5 & $45^{\circ}$ & & A $106 \mathrm{C}$ & 1260 & 325 & 440 & 26.250 & 514 & 0.0196 & & 0.0196 & 0.1585 & 526 & 3981 \\
\hline Straighth & 30.5 & 1 & $705-706$ & 10.75 & 0.593 & & & & 210.6 & A $106 \mathrm{C}$ & 1260 & 325 & 440 & 26,250 & 471 & 0.0179 & & 0.0179 & 0.1585 & 624 & 2192 \\
\hline Bend & 306 & 3 & $706-707$ & 10.75 & 0.593 & 15 & 1.5 & $45^{\circ}$ & & A $106 \mathrm{C}$ & 1260 & 325 & 440 & 26.250 & 875 & 0.0333 & & 0.0333 & 0.1585 & 232 & 988 \\
\hline Izend & 307 & 3 & $707-708$ & 10.75 & 0.593 & 15 & 1.5 & $60^{\circ}$ & & A $106 \mathrm{C}$ & 1260 & 325 & 440 & 26.250 & 851 & 0.0324 & & 0.0324 & 0.1585 & 644 & 603 \\
\hline Hanger & & D-2 & 708 & & & & & & & & & & & & 807 & 0.0307 & 1.0 & 0.0307 & & 1346 & 1136 \\
\hline Straighth & 308 & 1 & 708-709 & 10.75 & 0.593 & & & & 168.7 & A $106 \mathrm{C}$ & 1260 & 325 & 440 & 26,250 & 1184 & 0.0451 & & 0.0451 & 0.1585 & 1123 & 1191 \\
\hline Bend & 309 & 3 & $709-710$ & 10.75 & 0.593 & 15 & 1.5 & $45^{\circ}$ & & $\mathrm{A} 106 \mathrm{C}$ & 1260 & 325 & 440 & 26.250 & 2160 & 0.0823 & & 0.0823 & 0.1585 & 1947 & 2180 \\
\hline Straight & 310 & 1 & $710-711$ & 10.75 & 0.593 & & & & 51.9 & $\mathrm{~A} 106 \mathrm{C}$ & 1260 & 325 & 440 & 26,250 & 1642 & 0.0626 & & 0.0626 & 0.1585 & 1046 & 1191 \\
\hline $10: 18 \mathrm{Red}$ & & D-6 & 711 & & & & & & & & & & & & 1642 & 0.0626 & 1.0 & 0.0626 & & 634 & 907 \\
\hline Tec 712 & 311 & 1 & $711-712$ & 18.0 & 0.937 & & & & 24.0 & A $106 \mathrm{C}$ & 1260 & 325 & 440 & 26,250 & 411 & 0.0157 & & 0.1605 & 0.4505 & 173 & 225 \\
\hline $\begin{array}{l}\text { Pressure Vess } \\
\text { Nozzle Weld }\end{array}$ & & $D-1$ & 721 & & & & & & & & & & & & 1983 & 0.0755 & 1.0 & 0.0755 & & 1594 & 1335 \\
\hline Strainght & 321 & 1 & $721-722$ & 10.75 & 0.593 & & & & 18.8 & A $106 \mathrm{C}$ & 1260 & 325 & 440 & 26,250 & 1983 & 0.0755 & & 0.0755 & 0.1585 . & 316 & 1565 \\
\hline Wold & & $D-1$ & 722 & & & & & & & & & & & & 2382 & 0.0907 & 1.0 & 0.0907 & & 575 & 2559 \\
\hline Elbow & 322 & 2 & $722-723$ & 10.75 & 0.593 & 15 & 1.5 & $90^{\circ}$ & & A $106 \mathrm{C}$ & 1260 & 325 & 440 & 26.250 & 2382 & 0.0907 & & 0.0907 & 0.1585 & 992 & 2565 \\
\hline Weld & & D- 1 & 723 & & & & & & & & & & & & 1745 & 0.0665 & 1.0 & 0.0665 & & 545 & 565 \\
\hline Straighth & 323 & 1 & $723-724$ & 10.75 & 0.593 & & & & 165.0 & $\mathrm{~A} 106 \mathrm{C}$ & 1260 & 325 & 440 & 26.250 & 1281 & 0.0488 & & 0.0488 & 0.1585 & 870 & 1699 \\
\hline Bend & 324 & 3 & $724-725$ & 10.75 & 0.593 & 15 & 1.5 & $49^{\circ}$ & & A106C & 1260 & 325 & 440 & 26,250 & 2371 & 0.0903 & & 0.0903 & 0.1585 & 1628 & 3236 \\
\hline of Tee 712 & 325 & 1 & $725-712$ & 10.75 & 0.593 & & & & 170.4 & $\mathrm{~A} 106 \mathrm{C}$ & 1260 & 325 & 440 & 26,250 & 2790 & 0.1063 & & 0.1605 & 0.1585 & 1510 & 1745 \\
\hline $10 \therefore$ & & D-4 & 712 & & & & & & & & & & & & 2790 & 0.1063 & 1.51 & 0.1605 & & 273 & 304 \\
\hline 18 -in. Run of Tee 712 & 312 & 1 & $712-713$ & 18.0 & 0.937 & & & & 139.4 & A106C & 1260 & 325 & 440 & 26,250 & 675 & 0.0257 & & 0.1605 & 0.4505 & 1153 & 571 \\
\hline Hanger & & $\mathrm{D}-2$ & $71:$ & & & & & & & & & & & & 1053 & 0.0401 & 1.0 & 0.0401 & & 2070 & 973 \\
\hline Bend & 313 & 3 & $713-714$ & 18.0 & 0.937 & 27 & 1.5 & $90^{\circ}$ & & A106C & 1260 & 325 & 440 & 26,250 & 1444 & 0.0550 & & 0.0550 & 0.4505 & 433 & 2331 \\
\hline Straight & 314 & 1 & $714-715$ & 18.0 & 0.937 & & & & 42.1 & $\mathrm{~A} 106 \mathrm{C}$ & 1260 & 325 & 440 & 26.250 & 849 & 0.0323 & & 0.0323 & 0.4505 & 259 & 1296 \\
\hline Weld & & $D-1$ & 715 & & & & & & & & & & & & 849 & 0.0323 & 1.0 & 0.0323 & 0.4505 & 219 & 909 \\
\hline Valve & 315 & 4 & $715-716$ & 18.0 & 4.5 & & & & 48.7 & $\mathrm{~A} 106 \mathrm{C}$ & 1260 & 325 & 440 & 26,250 & 325 & 0.0128 & & 0.0128 & 0.4505 & 83 & 345 \\
\hline Weld & & D-1 & 71 & & & & & & & & & & & & 882 & 0.0336 & 1.0 & 0.0336 & & 69 & 571 \\
\hline Straight & 316 & 1 & $716-717$ & 18.0 & 0.937 & & & & 47.0 & A106C & 1260 & 325 & 440 & 26,250 & 915 & 0.0349 & & 0.0349 & 0.4505 & 182 & 1507 \\
\hline Weld & & D-1 & 717 & & & & & & & & & & & & 1632 & 0.0622 & 1.0 & 0.0622 & & 164 & 2743 \\
\hline Elbow & 317 & 2 & $717-718$ & 18.0 & 0.937 & 27 & 1.5 & $90^{\circ}$ & & A106C & 1260 & 325 & 440 & 26,250 & 2005 & 0.0764 & & 0.0764 & 0.4505 & 234 & 2446 \\
\hline Weld & & D-1 & & & & & & & & & & & & & 2005 & 0.0764 & 1.0 & 0.0764 & & 296 & 2446 \\
\hline Isolation Valve & 318 & 4 & $718-719$ & 18.0 & 4.5 & & & & 31.0 & $\mathrm{~A} 106 \mathrm{C}$ & 1260 & 325 & 440 & 26,250 & 485 & 0.0185 & & 0.0185 & 0.4505 & 294 & 1093 \\
\hline
\end{tabular}




\begin{tabular}{|c|c|c|c|c|c|c|c|c|c|c|c|c|c|c|c|c|c|c|c|c|c|}
\hline $\begin{array}{l}\text { Model Number } 2 \\
\text { Feed Water (North Side) } \\
\text { Component } \\
\text { or Discontinuity } \\
\end{array}$ & 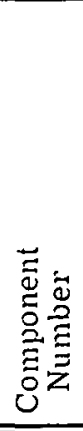 & $\sum_{F}^{\infty}$ & 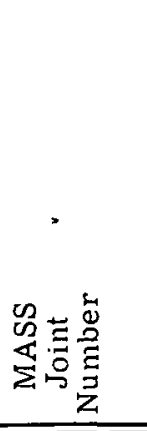 & 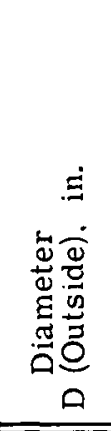 & 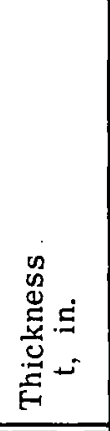 & 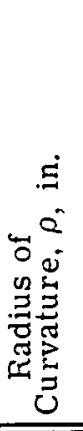 & $e_{e}^{*}$ & 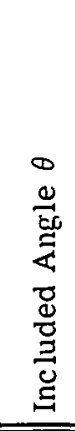 & 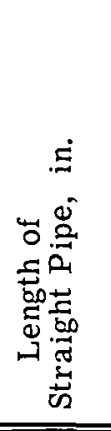 & 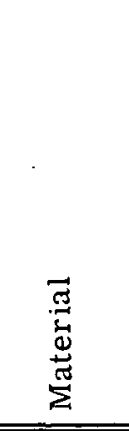 & 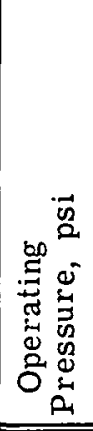 & 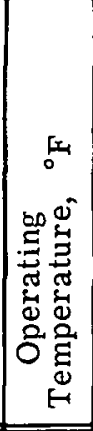 & 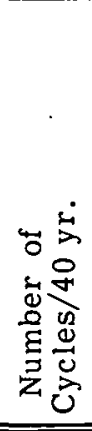 & 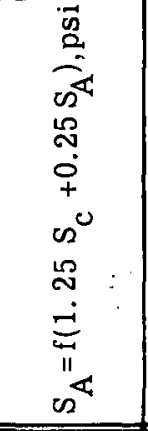 & 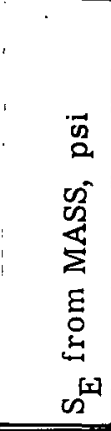 & $\underbrace{0^{4}}_{0^{\sqrt{2}}}$ & 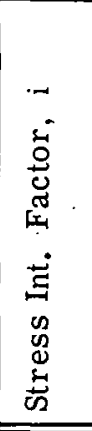 & 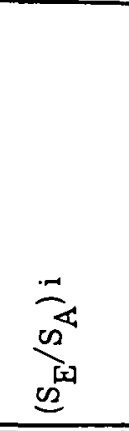 & 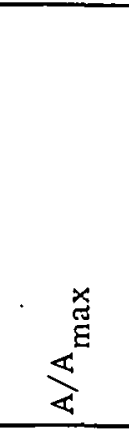 & 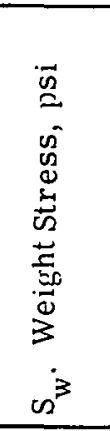 & 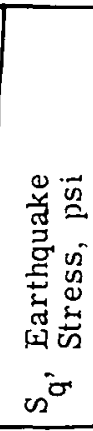 \\
\hline $\begin{array}{l}\text { Pressure Vessel } \\
\text { Nozzle Weld }\end{array}$ & & D-1 & & & & & & & & & & & & & 892 & 0.0340 & 1.0 & 0.0340 & & 2633 & 3634 \\
\hline Straight & 351 & 1 & $751-752$ & 10.75 & 0.593 & & & & 18.8 & A $106 \mathrm{C}$ & 1260 & 325 & 440 & 26,250 & 892 & 0.0340 & & 0.0340 & 0.1585 & 994 & 3602 \\
\hline Weld & & D-1 & 752 & & & & & & & & & & & & 985 & 0.0375 & 1.0 & 0.0375 & & 1780 & 4549 \\
\hline Elbow & 352 & 2 & $752-753$ & 10.75 & $0: 593$ & 15 & 1.5 & $90^{\circ}$ & & A106C & 1260 & 325 & 440 & 26,250 & 1270 & 0.0484 & & 0.0484 & 0.1585 & 665 & 5513 \\
\hline Weid & & D-1 & 753 & & & & & & & & & & & & 1270 & 0.0484 & 1.0 & 0.0484 & & 363 & 5513 \\
\hline Straight & 353 & 1 & 753-754 & 10.75 & 0.593 & & & & 130.9 & A106C & 1260 & 325 & 440 & 26.250 & 704 & 0.0268 & & 0.0268 & 0.1585 & 362 & 3046 \\
\hline Bend & 354 & 3 & $754-755$ & 10.75 & 0.593 & & & & 210.6 & A $106 \mathrm{C}$ & 1260 & 325 & 440 & 26.250 & 514 & 0.0196 & & 0.0196 & 0.1585 & 663 & 5878 \\
\hline Straight & 355 & 1 & $755-756$ & 10.75 & 0.593 & & & & 210.6 & A $106 \mathrm{C}$ & 1260 & 325 & 440 & 26,250 & 471 & 0.0179 & & 0.0179 & 0.1585 & 873 & 3237 \\
\hline Bend & 356 & 3 & $756-757$ & 10.75 & 0.593 & 15 & 1.5 & $45^{\circ}$ & & A $106 \mathrm{C}$ & 1260 & 325 & 440 & 26,250 & 876 & 0.0334 & & 0.0334 & 0.1585 & 239 & 790 \\
\hline Bencl & 357 & 3 & $757-758$ & 10.75 & 0.593 & 15 & 1.5 & $60^{\circ}$ & & A $106 \mathrm{C}$ & $12 \epsilon 0$ & 325 & 440 & 26.250 & 852 & 0.0325 & & 0.0325 & 0.1585 & 682 & 707 \\
\hline Hanger & & D-2 & 758 & & & & & & & & & & & & 808 & 0.0308 & 1.0 & 0.0308 & & 1397 & 1650 \\
\hline Straight & 358 & 1 & $758-759$ & 10.75 & 0.593 & & & & 168.7 & A $106 \mathrm{C}$ & 1260 & 325 & 440 & 26.250 & 1183 & 0.0451 & & 0.0451 & 0.1585 & 1923 & 1472 \\
\hline Bend & 359 & 3 & $759-760$ & 10.75 & 0.593 & 15 & 1.5 & $45^{\circ}$ & & A $106 \mathrm{C}$ & 1260 & 325 & 440 & 26.250 & 2160 & 0.0823 & & 0.0823 & 0.1585 & 1823 & 2694 \\
\hline Straighth & 360 & 1 & $760-761$ & 10.75 & 0.593 & & & & 51.9 & A $106 \mathrm{C}$ & 1260 & 325 & 440 & 26,250 & 1642 & 0.0626 & & 0.0626 & 0.1585 & 1038 & 1442 \\
\hline $10: 18$ Reducer & & D-6 & & & & & & & & & & & & & 1642 & 0.0626 & 1.0 & 0.0626 & & 611 & 909 \\
\hline 18-in. Run or Tee 762 & 361 & 1 & $761-762$ & 18.0 & 0.937 & & & & 24.0 & A $106 \mathrm{C}$ & 1260 & 325 & 440 & 26.250 & 411 & 0.0157 & & 0.1605 & 0.4505 & 166 & 242 \\
\hline $\begin{array}{l}\text { Pressure Vesse } \\
\text { Nozz:le Weld }\end{array}$ & & $\mathrm{D}-1$ & & & & & & & & & & & & & 1983 & 0.0755 & 1.0 & 0.0755 & & 1598 & 1408 \\
\hline Straighlt & 371 & 1 & $771-772$ & 10.75 & 0.593 & & & & 18.8 & A $106 \mathrm{C}$ & 1260 & 325 & 440 & 26.250 & 1983 & 0.0755 & & 0.0755 & 0.1585 & 312 & 1680 \\
\hline Weld & & $D-1$ & & & & & & & & & & & & & 2381 & 0.0907 & 1.0 & 0.0907 & & 569 & 2865 \\
\hline Ellow & 372 & 2 & $772-773$ & 10.75 & 0.593 & 15 & 1.5 & $90^{\circ}$ & & A106C & 1260 & 325 & 440 & 26.250 & 2381 & 0.0907 & & 0.0907 & 0.1585 & 1003 & 2800 \\
\hline Weld & & $\mathrm{D}-1$ & 773 & & & & & & & & & & & & 1745 & 0.0665 & 1.0 & 0.0665 & & 551 & 2800 \\
\hline Straight & 373 & 1 & $773-774$ & 10.75 & 0.593 & & & & 165.8 & $\mathrm{~A} 106 \mathrm{C}$ & 1260 & 325 & 440 & 26.250 & 1281 & 0.0488 & & 0.0488 & 0.1585 & 873 & 1766 \\
\hline Bend & 374 & 3 & $774-775$ & 10.75 & 0.593 & 15 & 1.5 & $49^{\circ}$ & & A $106 \mathrm{C}$ & 1260 & 325 & 440 & 26.250 & 2370 & 0.0903 & & 0.0903 & 0.1585 & 1634 & 3620 \\
\hline 10-in. Branch of Tee 762 & 375 & 1 & $775-762$ & 10.75 & 0.593 & & & & 170.4 & A $106 \mathrm{C}$ & 1260 & 325 & 440 & 26.250 & 2789 & 0.1062 & & 0.1605 & 0.1585 & 1517 & 1953 \\
\hline $10 \cdot 18$ Tee 762 & & D-4 & 762 & & & & & & & & & & & & 2789 & 0.1062 & 1.51 & 0.1605 & & 866 & 1031 \\
\hline 18-in. Run of Tee 762 & 362 & 1 & $762-763$ & 18.0 & 0.937 & & & & 139.4 & A $106 \mathrm{C}$ & 1260 & 325 & 440 & 26.250 & 675 & 0.0257 & & 0.1605 & 0.4505 & 1147 & 333 \\
\hline Hanger & & D-2 & 763 & & & & & & & & & & & & 1053 & 0.0401 & 1.51 & 0.0401 & & 2060 & 673 \\
\hline Bend & 363 & 3 & $763-764$ & 18.0 & 0.937 & 27 & 1.5 & $90^{\circ}$ & & A $106 \mathrm{C}$ & 1260 & 325 & 440 & 26.250 & 1444 & 0.0550 & & 0.0550 & 0.4505 & 425 & 2442 \\
\hline Straight & $364^{\circ}$ & 1 & $764-765$ & 18.0 & 0.937 & & & & 42.1 & A $106 \mathrm{C}$ & 1260 & 325 & 440 & 26.250 & 849 & 0.0323 & & 0.0323 & 0.4505 & 216 & 1373 \\
\hline Weld & & D-1 & 765 & & & & & & & & & & & & 849 & 0.0323 & 1.51 & 0.0323 & & 82 & 958 \\
\hline Valve & 365 & 4 & $765-766$ & 18.0 & 4.5 & & & & 48.5 & A $106 \mathrm{C}$ & 1260 & 325 & 440 & 26.250 & 335 & 0.0128 & & 0.0128 & 0.1403 & 69 & 364 \\
\hline Weld & & $\mathrm{D}-1$ & 766 & & & & & & & & & & & & 882 & 0.0336 & 1.51 & 0.0336 & & 182 & 651 \\
\hline Straight & 366 & 1 & $766-767$ & 18.0 & 0.937 & & & & 47.0 & A106C & 1260 & 325 & 440 & 26.250 & 915 & 0.0349 & & 0.0349 & 0.4505 & 166 & 1621 \\
\hline Weld & & D-1 & 767 & & & & & & & & & & & & 1633 & 0.0622 & 1.51 & 0.0622 & & 243 & 2928 \\
\hline Elbuw & 367 & 2 & $767-768$ & 18.0 & 0.937 & 27 & 1.5 & $90^{\circ}$ & & $\mathrm{A} 106 \mathrm{C}$ & 1260 & 325 & 440 & 26.250 & 2005 & 0.0764 & & 0.0764 & 0.4505 & 291 & 2501 \\
\hline Weld & & $\mathrm{D}-1$ & & & & & & & & & & & & & 2005 & 0.0764 & 1.51 & 0.0764 & & 65 & 2501 \\
\hline Isolation vall & 368 & 4 & $768-769$ & 18.0 & 4.5 & & & & 31.0 & A $106 \mathrm{C}$ & 1260 & 325 & 440 & $26.250_{i}^{i}$ & 485 & 0.0184 & & 0.0184 & 0.1403 & 300 & 1114 \\
\hline
\end{tabular}




\begin{tabular}{|c|c|c|c|c|c|c|c|c|c|c|c|c|c|c|c|c|c|c|c|c|c|}
\hline $\begin{array}{l}\therefore \\
\therefore \\
\qquad \\
\text { Model Number. } 3 \\
\text { Control Rod Drive } \\
\text { (From C. R. D. to P. V.) } \\
\text { Component } \\
\text { or Discontinuity } \\
\end{array}$ & 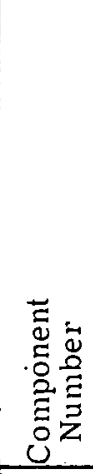 & 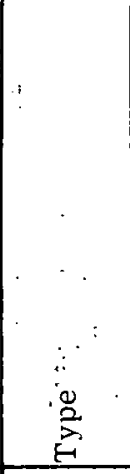 & 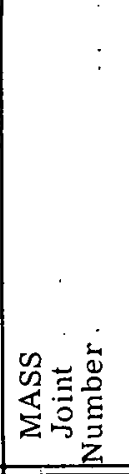 & 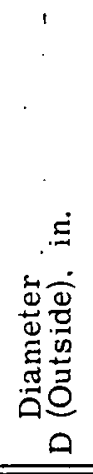 & 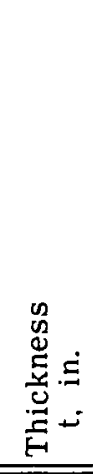 & 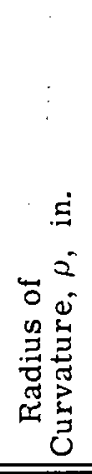 & $\stackrel{\stackrel{*}{\alpha}}{e^{2}}$ & 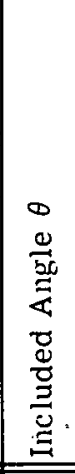 & 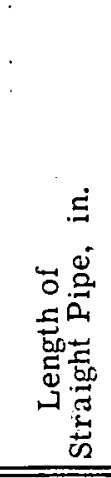 & 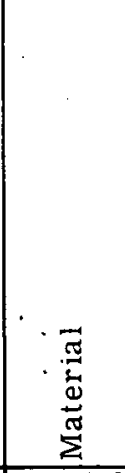 & 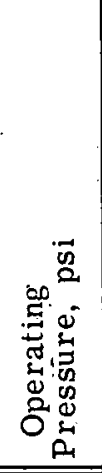 & 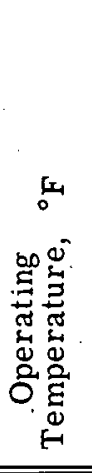 & 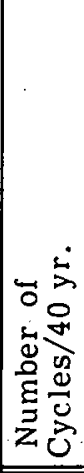 & 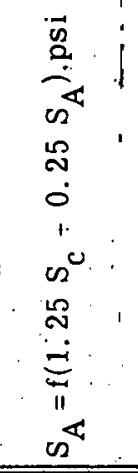 & 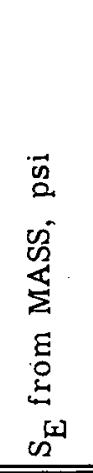 & 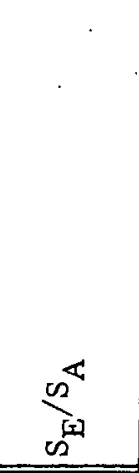 & 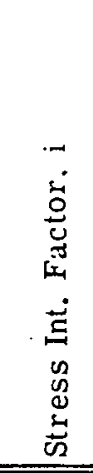 & 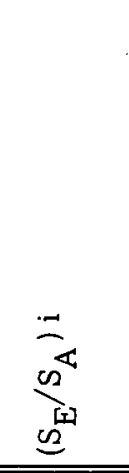 & 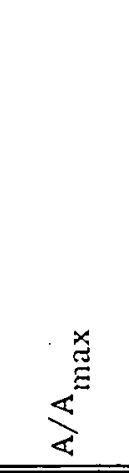 & 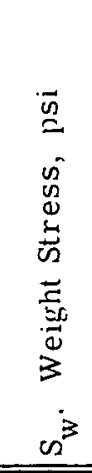 & 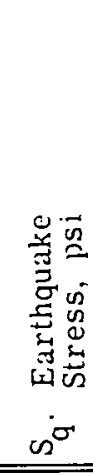 \\
\hline $\begin{array}{l}\text { Pressure Vessel } \\
\text { Nozzle Weld }\end{array}$ & & D-1 & 1 & & & & & & & $\begin{array}{l}\text { Sean1- } \\
\text { less }\end{array}$ & & & & & 1675 & 0.0642 & 1.0 & 0.0642 & & 3520 & 5570 \\
\hline "Straight & 401 & 1. & $1-2$ & 3.5 & $0.3^{\prime}$ & & & & 42.8 & 304 & 1000 & 551 & 360 & $.26,100$ & 1675 & 0.0642 & & 0.0642 & 0.0146 & 3520 & 4480 \\
\hline Weld & & $D-1$ & 2 & & & & & & & & & & & & 1821 & 0.0698 & 1.0 & 0.0698 & & 314 & 4600 \\
\hline Elbow & 402 & 2 & $2-3$ & 3.5 & 0.3 & 5 & 1.6 & $90^{\circ}$ & & 304 & 1000 & 551 & 360 & 26.100 & 1841 & 0.0706 & & 0.0706 & 0.0146 & 788 & 5320 \\
\hline Weld & & D-1 & 3 & & & & & & & & & & & & 1753 & 0.0672 & 1.0 & 0.0672 & & 788 & 5320 \\
\hline N Straight & 403 & 1 & $3-4$ & 3.5 & 0.3 & & & & 153.0 & 304 & 1000 & 551 & 360 & 26,100 & 1387 & 0.0531 & & 0.0531 & 0.0146 & 613 & 5320 \\
\hline Weld & & D-1 & 4 & & & & & & & & & & & & 784 & 0.0300 & 1.0 & 0.0300 & & 696 & 4890 \\
\hline ;i Elbow" , & 404 & 2 & $4-5$ & 3.5 & 0.3 & 5 & 1.6 & $90^{\circ}$ & & 304 & 1000 & 551 & 360 & 26.100 & 859 & 0.0329 & & 0.0329 & 0.0146 & 696 & 4890 \\
\hline Weld & & D-1 & 5 & & & & & & & & & & & & 859 & 0.0329 & 1.0 & 0.0329 & & 671 & 4030 \\
\hline Straight & 405 & 1 & $5-6$ & 3.5 & 0.3 & & & & 44.0 & 304 & 1000 & 551 & 360. & 26.100 & 722 & 0.0277 & & 0.0277 & 0.0146 & 523 & 4220 \\
\hline H:anger and Weld & & D-1.2 & 6 & & & & & & & & & & & & 882 & 0.0338 & 1.0 & 0.0338 & & 258 & 4380 \\
\hline$\because \quad$ Elbow & 406 & 2 & $6-7$ & 3.5 & 0.3 & 5 & 1.6 & $90^{\circ}$ & & 304 & 1000 & 551 & 360 & 26.100 & 882 & 0.0338 & & 0.0338 & 0.0146 & 258 & 4940 \\
\hline Weld & & $D-1$ & 7 & & & & & & & & & & & & 767 & 0.0294 & 1.0 & 0.0294 & & 208 & 4940 \\
\hline Straight & 407 & 1 & $7-8$ & 3.5 & $0.3:$ & & & & 37.0 & 304 & 1000 & 551 & 360 & 26.100 & 714 & 0.0274 & & 0.0274 & 0.0146 & 389 & 3840 \\
\hline Hanger & & D-2 & 8 & & & & & & & & & & & & 714 & 0.0274 & 1.0 & 0.0274 & & 389 & 1410 \\
\hline Bend & 408 & 3 & $8-9$ & 3.5 & 0.3 & 40 & 13.3 & $45^{\circ}$ & & 304 & 1000 & $55 \cdot 1$ & $360^{\circ}$ & $26.100^{\circ}$ & 805 & 0.0308 & & 0.0308 & 0.0146 & 844 & 1410 \\
\hline Hanger & & $\mathrm{D}-2$ & 9 & & & & & & & & & & & & 805 & 0.0308 & 1.0 & 0.0308 & & 844 & 889 \\
\hline Straight & 409 & 1 & $9-10$ & 3.5 & 0.3 & & & & 145.0 & 304 & 1000 & 551 & 360 & 26,100 & 1260 & 0.0483 & & 0.0483 & 0.0146 & 844 & 1100 \\
\hline Hanger & & D-2 & 10 & & & & & & & & & & & & 1260 & 0.0483 & 1.0 & 0.0483 & & 532 & 1100 \\
\hline if Bend & 410 & 3 & $\cdot 10-11$ & 3.5 & 0.3 & 40 & 13.3 & $45^{\circ}$ & & 304 & 1000 & 551 & 360. & 26. 100 & 1291 & 0.0495 & & 0.0495 & 0.0146 & 561 & 1560 \\
\hline Hanger & & D-2 & 11 & & & & & & & & & & & & 1250 & 0.0479 & 1.0 & 0.0479 & & 561 & 1560 \\
\hline Straight & 411 & 1 & $11-12$ & 3.5 & 0.3 & & & & & 304 & 1000 & 551 & 360 & 26. 100 & 1250 & 0.0479 & & 0.0479 & 0.0146 & 570 & 1560 \\
\hline Hanger & & D-2 & 12 & & & & & & & & & & & & 667 & 0.0256 & 1.0 & 0.0256 & & 570 & 1110 \\
\hline Bend & 4.12 & 3 & $12-13$ & 3.5 & 0.3 & 40 & 13.3 & $45^{\circ}$ & & 304 & 1000 & 551 & 360 . & 26,100 & 667 & 0.0256 & & 0.0256 & 0.0146 & 570 & 1110 \\
\hline Hanger & & D-2 & 13 & 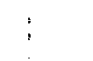 & & & & & & & & & & & 486 & 0.0186 & 1.0 & 0.0186 & & 430 & 960 \\
\hline 1. Straight & 413 & 1 & $13-14$ & 3.5 & 0.3 & & & & 104.2 & 304 & 1000 & 551 & 360 & 26,100 & 989 & 0.0379 & & 0.0379 & 0.0146 & 430 & 3420 \\
\hline$\therefore$ Benid. & 414 & 3 & 11.15 & 3.5 & 0.3 & 5 & 1.3 & $90^{\circ}$ & & 304 & $1.0 n n$ & 551. & $36 n$ & 26. 100 & 1278 & 0.0490 & & 0.0490 & 0.0146 & 140 & 4400 \\
\hline Hanger & & D-2 & 15 & & & & & & & & & & & & 1278 & 0.0490 & 1.0 & 0.0490 & & 96 & 4400 \\
\hline$\therefore$ Straight, & 415 & 1 & $\cdot 15-16$ & 3.5 & 0.3 & & & & 192.4 & 304 & 1000 & 551 & 360 & 26,100 & 1018 & 0.0390 & & 0.0390 & 0.0146 & 80 & 3970 \\
\hline $\begin{array}{l}\text { Connection to Isolation } \\
\text { Valve }\end{array}$ & & D-1 & 16 & & & & & & & & & & & & 973 & 0.0373 & 1.0 & 0.0373 & & 66 & 3970 \\
\hline Isolation Valve & 416 & 4. & $\cdot 16-17$ & 3.5 & 0.3 & & & & 12.0 & 304 & 1000 & 551 & 360 & 26.100 & 579 & 0.0222 & & 0.0222 & 0.0050 & 460 & 2680 \\
\hline
\end{tabular}




\begin{tabular}{|c|c|c|c|c|c|c|c|c|c|c|c|c|c|c|c|c|c|c|c|c|c|}
\hline $\begin{array}{l}\text { S } \\
\vdots \\
\text { Model Number } 3 \\
\text { Control Rod Drive } \\
\text { (Insert) } \\
\quad \text { Component } \\
\text { or Discontinuity }\end{array}$ & 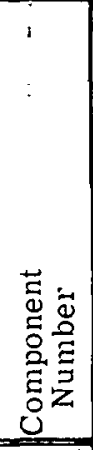 & 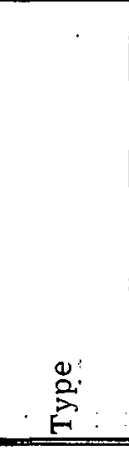 & 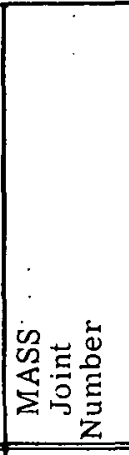 & 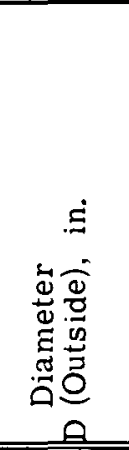 & 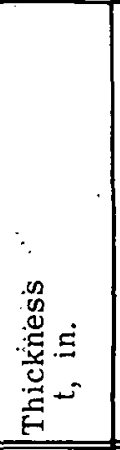 & 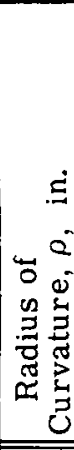 & $e^{*}$ & 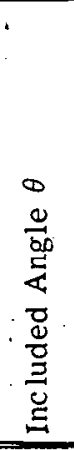 & 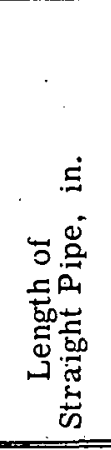 & 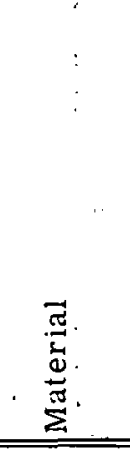 & 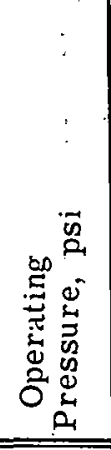 & 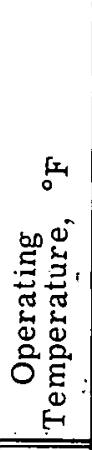 & 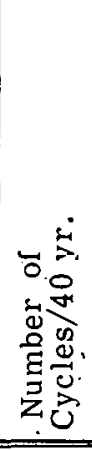 & 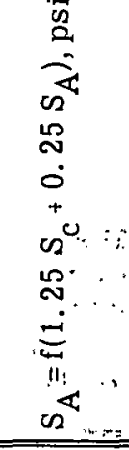 & 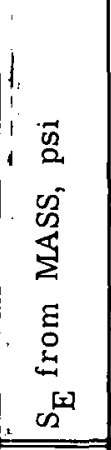 & $\begin{array}{c}0^{4} \\
0^{4} \\
0\end{array}$ & 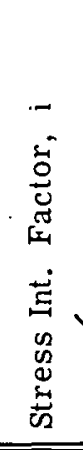 & 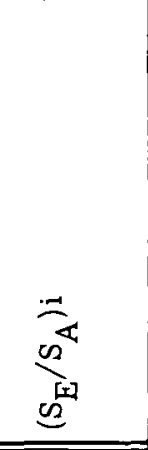 & 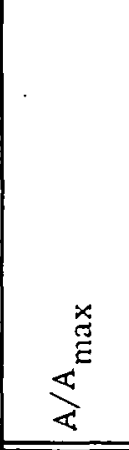 & 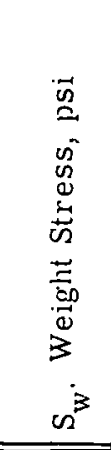 & 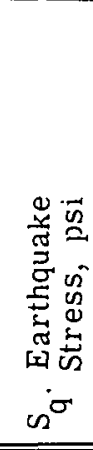 \\
\hline Weld to CRD Thimble & & D-1a & 21 & & & & & & & $\begin{array}{l}\text { Seam- } \\
\text { less }\end{array}$ & & & & & 6857 & 0.2627 & 1.3 & 0.3415 & & 1867 & 3689 \\
\hline Straight & 421 & 1 & $21-22$ & 1.050 & 0.154 & & & & 28,0 & 304 & 1000 & 551 & 200 & 26,100 & 6857 & 0.2627 & & 0.2627 & 0.001 & 1898 & 3689 \\
\hline :Bend & 422 & 3 & $22-23$ & 1.050 & 0.154 & 5 & 0.66 & $90^{\circ}$ & & 304 & 1000 & 551 & 200 & 26,100 & 3351 & 0.1284 & & 0.1284 & 0.001 & 1936 & 1507 \\
\hline $\begin{array}{l}\text { Sorket Weld Reducer } \\
\text { Coupling }\end{array}$ & & D-1a. 6 & 23 & & & & & & & & & & & & 2902 & 0.1112 & 1.3 & 0.1446 & & 1936 & 2223 \\
\hline$\therefore$ Bend & 423 & 3 & $23-24$ & 1.316 & 0.179 & 5 & 5 & $60^{\circ}$ & & 304 & 1000 & 551 & 200 & 26.100 & !1615 & 0.0619 & & 0.0619 & 0.0016 & 1026 & 1338 \\
\hline Straight & 424 & 1 & $24-25$ & 1.316 & $0.179:$ & & & & 5.6 & 304 & 1000 & 551 & 200 & 26.100 & ·1649| & 0.0632 & & 0.0632 & 0.0016 & 974 & 1339 \\
\hline Bend & 425 & 3 & $25-26$ & 1.316 & 0.179 & 5 & 5 & $60^{\circ}$ & & 304 & 1000 & 551 & 200 & 26.100 & ;1771 & 0.0679 & & 0.0679 & 0.0016 & 836 & 1344 \\
\hline Straight & 426 & 1 & $26-27$ & 1.316 & 0.179 & & & & 43.7 & 304 & 1000 & 551 & 200 & 26,100 & 2475 & 0.0948 & & 0.0948 & 0.0016 & 1770 & 1167 \\
\hline Bend & 427 & 3 & $27-28$ & 1.316 & 0.179 & 5 & 5 & $90^{\circ}$ & & 304 & .1000 & 551 & 200 & 26.100 & 2475 & 0.0948 & & 0.0948 & 0.0016 & 1770 & 915 \\
\hline Hanger & & $D-2$ & 28 & & & & & & & & & & & & 2234 & 0.0856 & 1.0 & 0.0856 & & 1120 & 770 \\
\hline Straight (Riser) & 428 & 1 & $28-29$ & 1.316 & 0.179 & & & & 88.0 & 304 & 1000 & 551 & 200 & 26. 100 & 3620 & 0.1387 & & 0.1387 & 0.0016 & 1120 & 770 \\
\hline Hanger & & D-2 & 29 & & & & & & & & & & & & : 3620 & 0.1387 & 1.0 & 0.1387 & & 764 & 451 \\
\hline Bend & 429 & 3 & $29-30$ & 1.316 & 0.179 & 5 & 5 & $90^{\circ}$ & & 304 & 1000 & 551 & 200. & 26,100 & 3861 & 0.1479 & & 0.1479 & 0.0016 & 1421 & 516 \\
\hline Straight & 430 & 1 & $30-31$ & 1.316 & 0.179 & & & & 52.5 & 304 & 1000 & 551 & $200^{\circ}$ & 26.100 & 3861 & 0.1479 & & 0.1479 & 0.0016 & 1421 & 516 \\
\hline Bend & 431 & 3 & $31-32$ & 1.316 & 0.179 & 10 & 10 & $30^{\circ}$ & & 304 & 1000 & 551 & 200 & 26.100 & 2933 & 0.1124 & & 0.1124 & 0.0016 & 1687 & 1036 \\
\hline Hanger & & D-2 & 32 & & & & & & & & & & & & ;2833 & 0.1085 & 1.0 & 0.1085 & & 1687 & 1032 \\
\hline Straight & 432 & 1 & $32-33$ & 1.316 & 0.179 & & & & 18.5 & 304 & 1000 & 551 & 200 & 26.100 & , 2833 & 0.1085 & & 0.1085 & 0.0016 & 1687 & 1032 \\
\hline Hanger & & D-2 & 33 & & & & & & & & & & & & 42586 & 0.0991 & 1.0 & 0.0991 & & 4319 & 841 \\
\hline Bend & 433 & 3 & 33-34 & 1.316 & 0.179 & 10 & 10 & $24^{\circ}$ & & $304^{\circ}$ & 1000 & 551 & 200 & 26.100 & $j^{2586}$ & 0.0991 & & 0.0991 & 0.0016 & 4319 & 1455 \\
\hline Straight & 434 & 1 & $34-35$ & 1.316 & 0.179 & & & & $188: 6$ & 304 & 1000 & 551 & 200 & 26,100 & !2514 & 0.0963 & & 0.0963 & 0.0016 & 2532 & 1455 \\
\hline Socket Weld $1 \mathrm{in} . \times 1 \mathrm{in}$. & & D-1a & 35 & & & & & & & & & & & & ' 993 & 0.0380 & 1.3 & 0.0494 & & 1171 & 762 \\
\hline . Straight & 435 & 1 & $35-36$ & 1.316 & 0.179 & & & & $81: 1$ & 304 & 1000 & 551 & 200 & 26.100 & 2433 & 0.0932 & & 0.0932 & 0.0016 & 3346 & 965 \\
\hline Hanger and Weld & & $D-1 a .2$ & 36 & & & & & & & & & & & & 2433 & 0.0932 & 1.3 & 0.1213 & & 3925 & 2040 \\
\hline
\end{tabular}




\begin{tabular}{|c|c|c|c|c|c|c|c|c|c|c|c|c|c|c|c|c|c|c|c|c|c|}
\hline $\begin{array}{l}\text { Model Number } 3 \\
\text { Control Rod Drive } \\
\text { Withdraw } \\
\text { Component } \\
\text { or Discontinuity } \\
\end{array}$ & 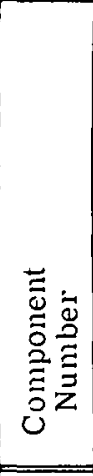 & 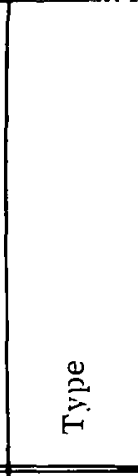 & 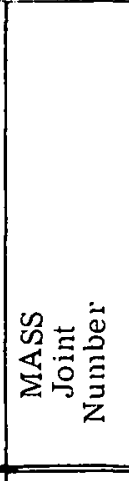 & 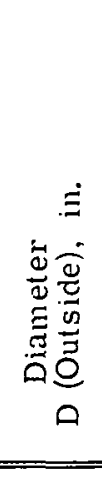 & 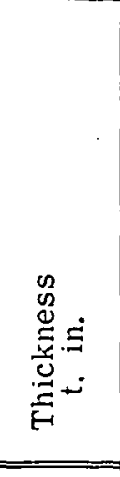 & 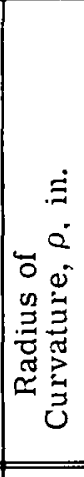 & $e^{*}$ & 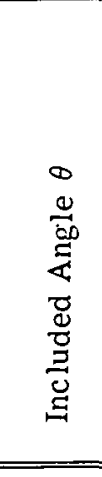 & 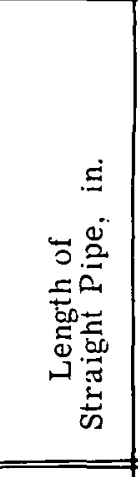 & 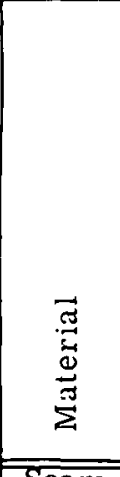 & 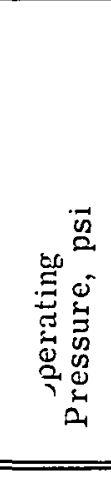 & 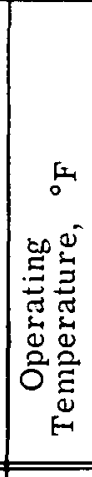 & 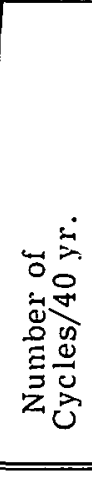 & 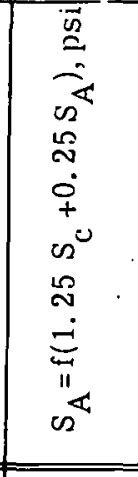 & 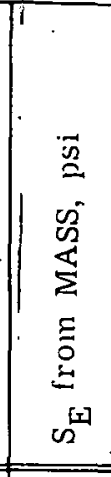 & 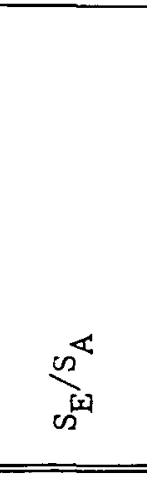 & 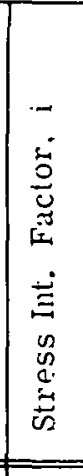 & 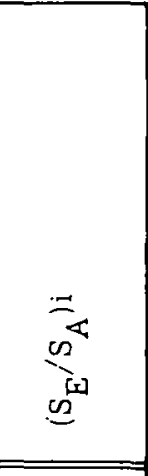 & $\underset{\mathbb{4}}{\stackrel{\tilde{E}}{=}}$ & 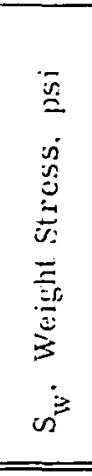 & 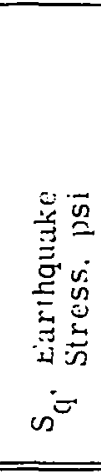 \\
\hline Weld at CRD Thimble & & D-1a & 41 & & & \multirow{5}{*}{5} & \multirow{4}{*}{5} & \multirow[b]{3}{*}{$90^{\circ}$} & \multirow{3}{*}{46.0} & \begin{tabular}{|l} 
Seam- \\
less
\end{tabular} & & & & & 2371 & 0.0908 & 1.3 & 0.1180 & & 2798 & 6033 \\
\hline Straight & 441 & 1 & $41-42$ & 1.05 & 0.154 & & & & & 304 & 1000 & 551 & 200 & 26.100 & 2371 & 0.0908 & & 0.0908 & 0.001 & 3520 & 6033 \\
\hline Bend & 442 & 3 & $42-43$ & 1.05 & 0.154 & & & & & 304 & 1000 & 551 & 200 & 26.100 & 1052 & 0.0403 & & 0.0403 & 0.001 & 3526 & 2105 \\
\hline Straight & 443 & 1 & $43-44$ & 1.05 & 0.154 & & & & \multirow[t]{2}{*}{49.0} & 304 & 1000 & 551 & 200 & 26,100 & 1346 & 0.0516 & & 0.0516 & 0.001 & 3041 & 2535 \\
\hline Bend & 444 & 3 & $44-45$ & 1.05 & 0.154 & & 5 & $60^{\circ}$ & & 304 & 1000 & 551 & 200 & 26.100 & 1349 & 0.0517 & & 0.0517 & 0.001 & 3041 & 677 \\
\hline Socket Weld & & $D-1 a$ & 45 & & & \multirow{4}{*}{5} & \multirow{4}{*}{5} & \multirow{4}{*}{$60^{\circ}$} & \multirow[b]{2}{*}{35.7} & & & & & & 1319 & 0.0505 & 1.3 & 0.0657 & & 2910 & 656 \\
\hline Straight & 445 & 1 & $45-46$ & 1.05 & 0.154 & & & & & 304 & 1000 & 551 & 200 & 26.100 & 1319 & 0.0505 & & 0.0505 & 0.001 & 2910 & 1536 \\
\hline Bend & 446 & 3 & $46-47$ & 1.05 & 0.154 & & & & \multirow{3}{*}{20.8} & 304 & 1000 & 551 & 200 & 26.100 & 1303 & 0.0499 & & 0.0499 & 0.001 & 1116 & 1536 \\
\hline Straight & 447 & 1 & $47-48$ & 1.05 & 0.154 & & & & & 304 & 1000 & 551 & 200 & 26.100 & 1538 & 0.0589 & & 0.0589 & 0.001 & 1434 & 1226 \\
\hline Bend & 448 & 3 & $48-49$ & 1.05 & 0.154 & \multirow[t]{2}{*}{5} & \multirow[t]{2}{*}{5} & \multirow{2}{*}{$90^{\circ}$} & & 304 & 1000 & 551 & 200 & 26.100 & 1538 & 0.0589 & \multirow{3}{*}{1.0} & 0.0589 & \multirow{2}{*}{0.001} & 1434 & 367 \\
\hline Hanger (Riser) & & D-2 & 49 & & & & & & \multirow{3}{*}{100.0} & & & & & & 1424 & 0.0546 & & 0.0546 & & 1199 & 968 \\
\hline Straight (in Riser) & 449 & 1 & $49-50$ & 1.05 & 0.154 & \multirow{4}{*}{5} & \multirow[b]{3}{*}{5} & \multirow[b]{3}{*}{$90^{\circ}$} & & 304 & 1000 & 551 & 200 & 26.100 & 2205 & 0.0845 & & 0.0845 & 0.001 & 1237 & 968 \\
\hline H:anger (Riser) & & $\mathrm{D}-2$ & 50 & & & & & & & & & & & & 2204 & 0.0844 & 1.0 & 0.0844 & & 1237 & 621 \\
\hline Bend & $45 n$ & 3 & $50-51$ & 1.05 & 0.154 & & & & & 304 & 1000 & 551 & 200 & 26.100 & 2323 & 0.0890 & & 0.0890 & 0.001 & 1237 & 720 \\
\hline Straight & 451 & 1 & $31-52$ & 1.05 & 0.154 & & & & 136.2 & 304 & 1000 & 551 & 200 & 26.100 & 2323 & 0.0890 & & 0.0890 & 0.001 & 1145 & .721 \\
\hline Bend & 452 & 3 & $52-53$ & 1.05 & 0.154 & 10 & 10 & $30^{\circ}$ & & 304 & 1000 & 551 & 200 & 26.100 & 1131 & 0.0433 & & 0.0433 & 0.001 & 1145 & 1163 \\
\hline Straight & 453 & 1 & .53-54 & 1.05 & 0.154 & & & & 124.8 & 304 & 1000 & 551 & 200 & 26.100 & 1066 & 0.0408 & & 0.0408 & 0.001 & 784 & 1043 \\
\hline Hanger & & D-2 & 54 & & & & & & & & & & & & 655 & 0.0255 & 1.0 & 0.0255 & & 378 & 934 \\
\hline Bend & 454 & 3 & $54-55$ & 1.05 & 0.154 & 10 & 10 & $24^{\circ}$ & & 304 & 1000 & 551 & 200 & 26,100 & 698 & 0.0267 & & 0.0267 & 0.001 & 1192 & 934 \\
\hline Straight & 455 & 1 & $55-56$ & 1.05 & 0.154 & & & & 12.0 & 304 & 1000 & 551 & 200 & 26.100 & 834 & 0.0320 & & 0.0320 & 0.001 & 1192 & 553 \\
\hline $\begin{array}{l}\text { Socket Weld Reducer } \\
1 \text { in. } \therefore 3 / 4 \text { in. }\end{array}$ & & D-1a, 6 & 56 & & & & & & & & & & & & 834 & 0.0320 & $\mid 1.3$ & 0.0416 & & 885 & 1072 \\
\hline Straight & 456 & 1 & $56-57$ & 1.05 & 0.154 & & & & 81.2 & 304 & 1000 & 551 & 200 & 26,100 & 1637 & 0.0627 & & 0.0627 & 0.001 & 885 & 1951 \\
\hline Hanger and Weld & & D-1a. 2 & 57 & & & & & & & & & & & & 1637 & 0.0627 & 1.3 & 0.0815 & & 547 & 1951 \\
\hline $\begin{array}{l}\text { Model Number } 3 \\
\text { Poison Spraty }\end{array}$ & & & & & & & & & & & & & & & & & & & & & \\
\hline $\begin{array}{l}\text { Weld to Pressure } \\
\text { Vessel Nozzle }\end{array}$ & & $\mathrm{D}-1 \mathrm{a}$ & 61 & & & & & & & $\begin{array}{l}\text { Seam- } \\
\text { less - }\end{array}$ & & & & & 2314 & 0.0887 & 1.3 & 0.1153 & & 529 & 5912 \\
\hline Straight & 461 & 1 & $61-62$ & 2.0 & $0.5^{\circ}$ & & & & 7.32 & 304 & 1000 & 551 & 370 & 26.100 & 2314 & 0.0887 & & 0.0887 & 0.0017 & 529 & 5912 \\
\hline 2 in. $\backslash 1-1 / 2$ in. Tee & & D-4 & 62 & & & & & & & & & & & & 1842 & 0.0706 & 1.0 & 0.0706 & & 65 & 4326 \\
\hline Straight & 462 & 1 & $62-63$ & 2.0 & 0.5 & & & & 7.32 & 304 & 1000 & 551 & 370 & 26,100 & 1842 & 0.0706 & & 0.0706 & 0.0017 & 607 & 4326 \\
\hline 2 in. $\times 1-1 / 2$ in. Reducer & & $\mathrm{D}-6$ & 63 & & & & & & & & & & & & 2596 & 0.0995 & 1.0 & 0.0995 & & 1085 & 5096 \\
\hline Straight & 463 & 1 & 63-64 & 1.9 & 0.2 & & & & 5.21 & 304 & 1000 & 551 & 370 & 26,100 & 2596 & 0.0995 & & 0.0995 & 0.0039 & 1936 & 5096 \\
\hline Hanger & & $\mathrm{D}-2$ & 64 & & & & & & & & & & & & 2273 & 0.0871 & 1.0 & 0.0871 & & 1936 & 3501 \\
\hline Bend & 464 & 3 & $64-65$ & 1.9 & 0.2 & 6 & 4 & $105^{\circ}$ & & 304 & 1000 & 551 & 370 & 26,100 & 2273 & 0.0871 & & 0.0871 & 0.0039 & 1936 & 3501 \\
\hline Straight & 465 & 1 & $65-66$ & 1.9 & 0.2 & & & & 490.0 & 304 & 1000 & 551 & 370 & 26,100 & 4491 & 0.1721 & & 0.1721 & 0.0039 & 260 & 375 \\
\hline Bend & 466 & 3 & $66-67$ & 1.9 & 0.2 & 6 & 4 & $90^{\circ}$ & & 304 & 1000 & 551 & 370 & 26.100 & 4491 & 0.1721 & & 0.1721 & 0.0039 & 944 & 245 \\
\hline Straight & 467 & 1 & $67-68$ & 1.9 & 0.2 & & & & 111.5 & 304 & 1000 & 551 & 370 & 26.100 & 12710 & 0.4870 & & 0.4870 & 0.0039 & 944 & 649 \\
\hline $\begin{array}{l}\text { Attachment to.Valve } \\
\text { and Hanger }\end{array}$ & & D-1a. 2 & 68 & & & & & & & & & & & & 12710 & 0.4870 & 1.3 & 0.6331 & & 184 & 2751 \\
\hline Isolation Valve & 468 & 4 & $68-69$ & 1.9 & 0.5 & & & & 9.0 & 304 & 1000 & 551 & 370 & 26,100 & 8998 & 0.3448 & & 0.3448 & 0.0039 & 2642 & 2995 \\
\hline
\end{tabular}




\begin{tabular}{|c|c|c|c|c|c|c|c|c|c|c|c|c|c|c|c|c|c|c|c|c|c|}
\hline $\begin{array}{l} \\
\vdots \\
\text { Model Number } 4 \\
\text { Emergency Condenser } \\
\text { Steam (North Side) } \\
\quad \text { Component } \\
\text { : or Discontinuity }\end{array}$ & 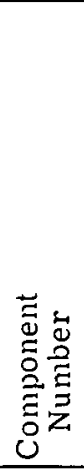 & 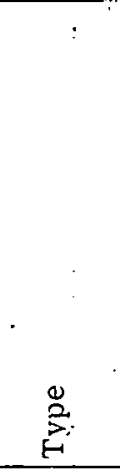 & 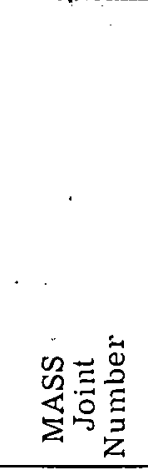 & 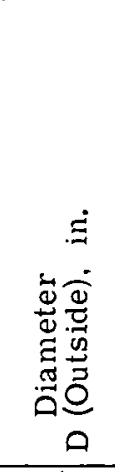 & 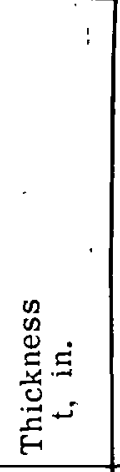 & 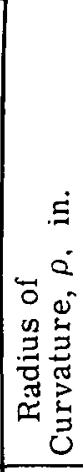 & $\stackrel{e}{e}^{*}$ & 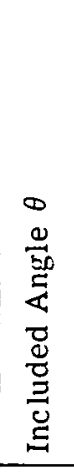 & 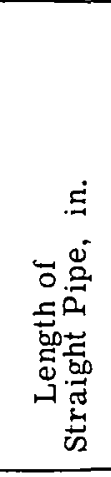 & 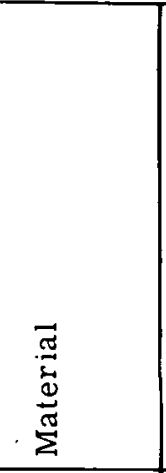 & 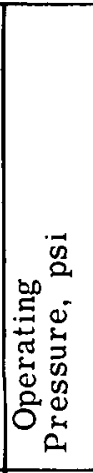 & 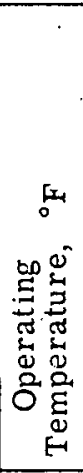 & 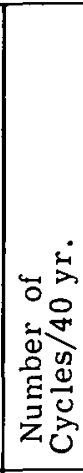 & 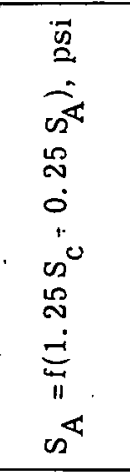 & 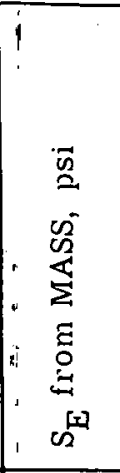 & 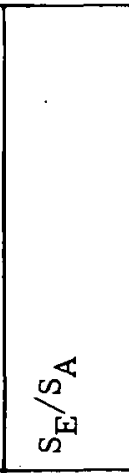 & 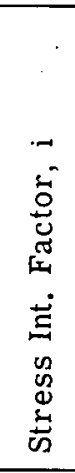 & 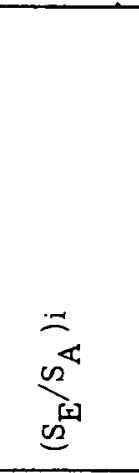 & 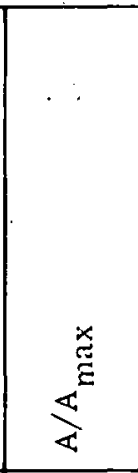 & 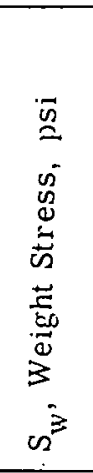 & 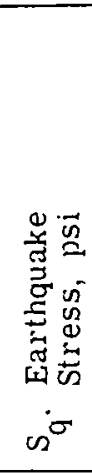 \\
\hline $\begin{array}{l}\text { Pressure Vessel } \\
\text { Nozzle Weld }\end{array}$ & & $D-1$ & & & & & & & & & & & & & 6974 & 0.2672 & 10 & 0.2672 & & 2217 & 2512 \\
\hline Straight & 501 & 1 & $161-162$ & 10.75 & 0.593 & & & & 3.0 & $\begin{array}{l}\text { Seam } \\
304\end{array}$ & 1000 & 552 & 500 & 26.100 & 7033 & 0.2695 & & 0.2695 & 0.1585 & 2166 & 2604 \\
\hline Weld & & D-1 & & & & & & & & & & & & & 17033 & 0.2695 & 1.0 & 0.2695 & & 3291 & 4060 \\
\hline Elbow & 502 & 2 & $162-163$ & 10.75 & 0.593 & 18 & 1.8 & $90^{\circ}$ & & 304 & 1000 & 552 & 500 & 26,100 & 11320 & 0.4337 & & 0.4337 & 0.1585 & 1973 & 4715 \\
\hline Weld & & D-1 & 163 & & & & & & & & & & & & 11320 & 0.4337 & 1.0 & 0.4337 & & 1973 & 4715 \\
\hline Straight & 503 & 1 & $163-164$ & 10.75 & 0.593 & & & & 43.5 & 304 & 1000 & 552 & 500 & 26,100 & 7161 & 0.2744 & & 0.2744 & 0.1585 & 1707 & 2949 \\
\hline Bend & 504 & 3 & $164-165$ & 10.75 & 0.593 & 48 & 4.8 & $70^{\circ}$ & & 304 & 1000 & 552 & 500 & 26,100 & 6390 & 0.2448 & & 0.2448 & 0.1585 & 2882 & 2662 \\
\hline Hanger & & D-2 & 165 & & & & & & & & & & & & 4325 & 0.1657 & 1.0 & 0.1657 & & 2882 & 1434 \\
\hline Straight & 505 & 1 & $165-166$ & 10.75 & 0.593 & & & & 111.9 & 304 & 1000 & 552 & 500 & 26. 100 & 5085 & 0.1948 & & 0.1948 & 0.1585 & 910 & 1904 \\
\hline Weld & & D-1 & 166 & & & & & & & & & & & & 7270 & 0.2785 & 1.0 & 0.2785 & & 1195 & 3073 \\
\hline Elbow & 506 & 2 & $166-167$ & 10.75 & 0.593 & 18 & 1.8 & $90^{\circ}$ & & 304 & 1000 & 552 & 500 & 26.100 & 8131 & 0.3115 & & 0.3115 & 0.1585 & 1172 & 3760 \\
\hline Weld & & D-1 & 167 & & & & & & & & & & & & 8131 & 0.3115 & 1.0 & 0.3115 & & 1172 & 3760 \\
\hline Straight & 507 & 1 & $167-168$ & 10.75 & 0.593 & & & & 156.0 & 304 & 1000 & 552 & 500 & 26,100 & 5321 & 0.2039 & & 0.2039 & 0.1585 & 2731 & 2469 \\
\hline Pipe to Valve Attachment & & D-1 & 168 & & & & & & & & & & & & $4770^{\circ}$ & 0.1828 & 1.0 & 0.1828 & & 2731 & 2469 \\
\hline Valve & 508 & 4 & $168-169$ & 10.75 & 0.593 & & & & 36.0 & 304 & 1000 & 552 & 500 & 26.100 & 2389 & 0.0915 & & 0.0915 & & 1111 & 1933 \\
\hline Valve to Valve Connection & & D-1 & & & & & & & & & & & & & 2389 & 0.0915 & 1.0 & 0.0915 & & 1078 & 1242 \\
\hline Valve & 509 & 4 & $169-170$ & 10.75 & 0.593 & & & & 36.0 & 304 & 1000 & 552 & 500 & 26,100 & 2907 & 0.1114 & & 0.1114 & & 1078 & 1306 \\
\hline Pipe to Valve Attachment & & $\mathrm{D}-1$ & 170 & & & & & & & & & & & & 7147 & 0.2738 & 1.0 & 0.2738 & & 1651 & 3210 \\
\hline Straight & 510 & 1 & $170-171$ & 10.75 & 0.593 & & & & 117.0 & 304 & 1000 & 552 & 500 & 26.100 & 11780 & 0.4513 & & 0.4513 & 0.1585 & 4635 & 2835 \\
\hline Reducer $(10,16)$ Hanger & & D-2.6 & 171 & & & & & & & & & & & & 11780 & 0.4513 & 1.0 & 0.4513 & & 4635 & 2835 \\
\hline Bend & 511 & 3 & $171-172$ & 16.0 & 0.843 & 60 & 3.75 & $90^{\circ}$ & & 30 & 1000 & 552 & 500 & 26. 100 & 4025 & 0.1542 & & 0.1542 & 0.3549 & 1461 & 1303 \\
\hline Straight & 512 & 1 & $172-173$ & 16.0 & 0.843 & & & & 266.0 & 304 & 1000 & 552 & 500 & 26,100 & 3685 & 0.1412 & & 0.1412 & 0.3549 & 436 & 1398 \\
\hline Bend & 513 & 3 & $173-174$ & 16.0 & 0.843 & $60^{\circ}$ & 3.75 & $90^{\circ}$ & & 304 & 1000 & 552 & 500 & 26.100 & 1786 & 0.0684 & & 0.0684 & 0.3549 & 436 & 1886 \\
\hline Hanger & & D-2 & 174 & & & & & & & & & & & & 1786 & 0.0684 & 1.0 & 0.0684 & & 190 & 1886 \\
\hline Straight & 514 & 1 & $174-175$ & 16.0 & 0.843 & & & & 6.0 & 304 & 1000 & 552 & 500 & $26: 100$ & 1809 & 0.0693 & & 0.0693 & 0.3549 & 183 & 1886 \\
\hline Bend & 515 & 3 & $175-176$ & 16.0 & 0.843 & 60 & 3.75 & $90^{\circ}$ & & 304 & 1000 & 552 & 500 & 26,100 & 1809 & 0.0693 & & 0.0693 & 0.3549 & 218 & 1827 \\
\hline 16-in. Run of Tee 177 & 516 & 1 & $176-177$ & 16.0 & 0.843 & & & & 73.0 & 304 & 1000 & 552 & 500 & 26,100 & 1259 & 0.0482 & & 0.1917 & 0.3549 & 218 & 1382 \\
\hline Tee $(16 \times 12)$ & & D- 4 & & & & & & & & & & & & & 3335 & 0.1278 & 1.5 & 0.1917 & & 45 & $1: 382$ \\
\hline 16-in. Run of Tee 177 & 517 & 1 & $177-178$ & 16.0 & 0.843 & & & & 10.0 & 304 & 1000 & 552 & 500 & $26: 100$ & 3480 & 0.1333 & & 0.1917 & 0.2242 & 45 & 577 \\
\hline Reducer $(16 \times 12)$ Weld & & D-1.6 & & & & & & & & & & & & & 6307 & 0.2416 & 1.0 & 0.2416 & & 121 & $182 \hat{6}$ \\
\hline Elbow & 518 & 2 & $178-179$ & 12.75 & 0.687 & 18 & 1.5 & $90^{\circ}$ & & 304. & 1000 & 552 & 500 & 26,100 & 6307 & 0.2416 & & 0.2416 & 0.2242 & 121 & 1826 \\
\hline
\end{tabular}




\begin{tabular}{|c|c|c|c|c|c|c|c|c|c|c|c|c|c|c|c|c|c|c|c|c|c|}
\hline $\begin{array}{l}\text { Model Number } 4 \\
\text { Emerrency Condenser } \\
\text { Stean! (North Side) } \\
\text { (Continued) } \\
\text { Component } \\
\text { or Discontinuity } \\
\end{array}$ & 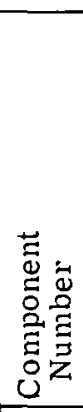 & 蛋 & 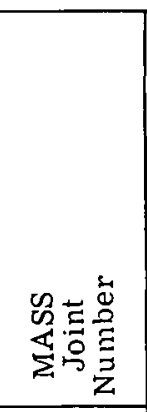 & 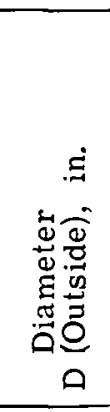 & 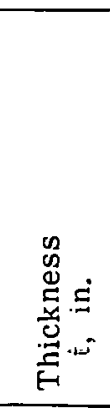 & 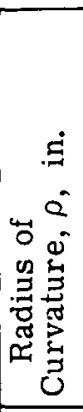 & $\stackrel{\stackrel{*}{a}}{a}$ & 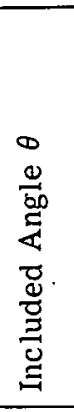 & 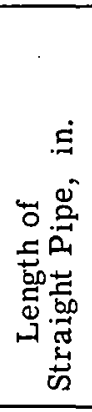 & 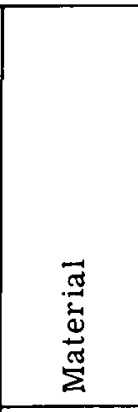 & 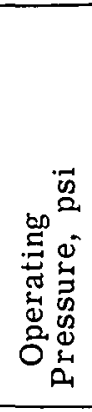 & 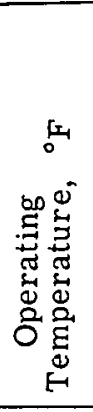 & 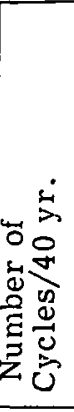 & 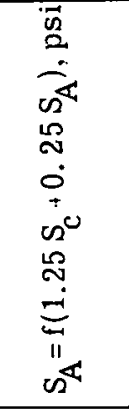 & 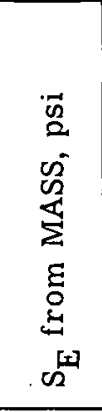 & 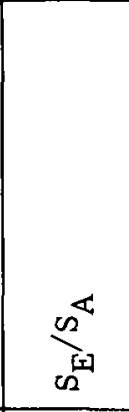 & 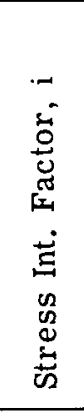 & 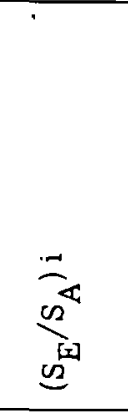 & 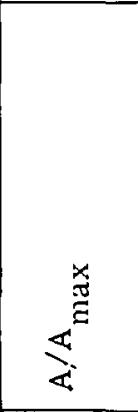 & 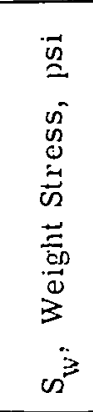 & 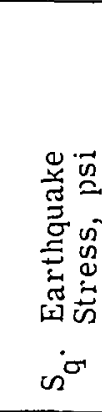 \\
\hline Weld & & $\mathrm{D}-1$ & 179 & & & & & & & Welded & & & & & 5239 & 0.2007 & 1.0 & 0.2007 & & $\overline{72}$ & 71588 \\
\hline Straight & 519 & 1 & $179-180$ & 12.75 & 0.687 & & & & 66.3 & 304 & 1000 & 552 & 500 & 26,100 & 3264 & 0.1251 & & 0.1251 & 0.2242 & 90 & 1096 \\
\hline Bend & 520 & 3 & $180-181$ & 12.75 & 0.687 & 60 & 5.0 & $90^{\circ}$ & & 304 & 1000 & 552 & 500 & 26.100 & 2037 & 0.0780 & & 0.0780 & 0.2242 & 316 & 1079 \\
\hline Straight & 521 & 1 & $181-182$ & 12.75 & 0.687 & & & & 9.4 & 304 & 1000 & 552 & 500 & 26,100 & 2144 & 0.0821 & & 0.0821 & 0.2242 & 377 & 1022 \\
\hline Hanger & & D-2 & 182 & & & & & & & & & & & & 2144 & 0.0821 & 1.0 & 0.0821 & & 377 & 1022 \\
\hline Bend & 522 & 3 & $182-183$ & 12.75 & 0.687 & 60 & 5.0 & $90^{\circ}$ & & 304 & 1000 & 552 & 500 & 26,100 & 3234 & 0.1239 & & 0.1239 & 0.2242 & 173 & 1022 \\
\hline Straight & 523 & 1 & $183-184$ & 12.75 & 0.687 & & & & 57.6 & 304 & 1000 & 552 & 500 & 26.100 & 3234 & 0.1239 & & 0.1239 & 0.2242 & 332 & 1384 \\
\hline Weld & & D- 1 & 184 & & & & & & & & & & & & 4301 & 0.1648 & 1.0 & 0.1648 & & 443 & 1789 \\
\hline Elbow & 524 & 2 & $184-185$ & 12.75 & 0.687 & 18 & 1.5 & $90^{\circ}$ & & 304 & 1000 & 552 & 500 & 26.100 & 4507 & 0.1727 & & 0.1727 & 0.2242 & 443 & 2756 \\
\hline Weld & & D-1 & 185 & & & & & & & & & & & & 450.7 & 0.1727 & 1.0 & 0.1727 & & 376 & 2756 \\
\hline Straighlit & 525 & 1 & .185-186 & 12.75 & 0.687 & & & & 14.5 & 304 & 1000 & 552 & 500 & 26.100 & 2733 & \begin{tabular}{|l|l|}
0.1047 \\
\end{tabular} & & 0.1047 & 0.2242 & 222 & 1622 \\
\hline $\begin{array}{l}\text { Emergency Condenser } \\
\text { Attachment }\end{array}$ & & D-1 & & & & & & & & & & & & & 3936 & 0.1508 & 1.0 & 0.1508 & & 169 & 1622 \\
\hline 12-in. Branch of Tee 177 & 526 & 1 & $177-190$ & 12.75 & 0.687 & & & & 84.3 & 304 & 1000 & 552 & 500 & 26.100 & 3936 & 0.1508 & & 0.1917 & 0.2242 & 334 & 4076 \\
\hline Bend & 527 & 3 & $190-191$ & 12.75 & 0.687 & 60 & 5.0 & $90^{\circ}$ & & 304 & 1000 & 552 & 500 & 26.100 & 2676 & 0.1025 & & 0.1025 & 0.2242 & 1291 & 3458 \\
\hline Hanger & & D-2 & 191 & & & & & & & & & & & & 2676 & 0.1025 & 1.0 & 0.1025 & & 1291 & 3458 \\
\hline Striaight & 528 & 1 & $191-192$ & 12.75 & 0.687 & & & & 51.4 & 304 & 1000 & 552 & 500 & 26.100 & 2883 & 0.1105 & & 0.1105 & 0.2242 & 1291 & 3458 \\
\hline Weld & & $\mathrm{D}-1$ & 192 & & & & & & & & & & & & 5048 & 0.1934 & 1.0 & 0.1934 & & 704 & 5323 \\
\hline Elbow & 529 & 2 & $192-193$ & 12.75 & 0.687 & 18 & 1.5 & $90^{\circ}$ & & 304 & 1000 & 552 & 500 & 26,100 & 5048 & 0.1934 & & 0.1934 & 0.2242 & 704 & 5322 \\
\hline Weld & & D-1 & 193 & & & & & & & & & & & & 3812 & 0.1461 & 1.0 & 0.1461 & & 179 & 3153 \\
\hline Straight & 530 & 1 & $193-194$ & 12.75 & 0.687 & & & & 40.4 & 304 & 1000 & 552 & 500 & 26.100 & 3615 & 0.1385 & & 0.1385 & 0.2242 & 530 & 1791 \\
\hline Weld & & D-1 & 194 & & & & & & & & & & & & 5044 & 0.1933 & 1.0 & 0.1933 & & 961 & $215 n$ \\
\hline Elbow & 531 & 2 & $194-195$ & 12.75 & 0.687 & 18 & 1.5 & $90^{\circ}$ & & 304 & 1000 & 552 & 500 & 26.100 & 6089 & 0.2333 & & 0.2333 & 0. 2242 & $9 r_{1}$ & 4373 \\
\hline Weld & & D-1 & & & & & & & & & & & & & 6089 & 0.2333 & 1.0 & 0.2333 & & 624 & 4373 \\
\hline Straight & 532 & 1 & $195-196$ & 12.75 & 0.687 & & & & 14.5 & 304 & 1000 & 552 & 500 & 26.100 & 3395 & 0.1301 & & 0.1301 & 0.2242 & 742 & 2398 \\
\hline Condenser Attachment & & D-1 & & & & & & & & & & & & & 2972 & 0.1139 & 1.0 & 0.1139 & & 742 & 2398 \\
\hline
\end{tabular}




\begin{tabular}{|c|c|c|c|c|c|c|c|c|c|c|c|c|c|c|c|c|c|c|c|c|c|}
\hline $\begin{array}{l}\text { Model Number } 4 \\
\text { Emergency Condenser } \\
\text { Steam (South Side) } \\
\text { Component } \\
\text { or Discontinuity }\end{array}$ & 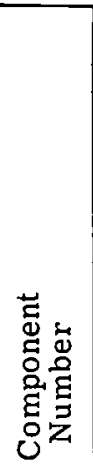 & 总 & 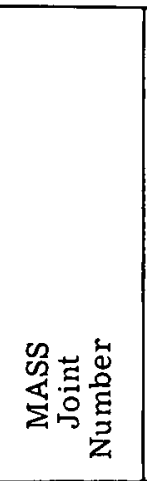 & 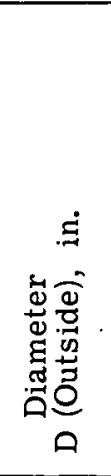 & 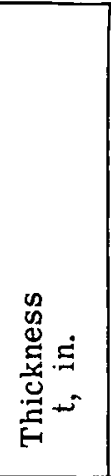 & 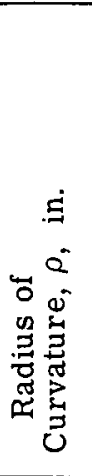 & $\stackrel{*}{Q}$ & 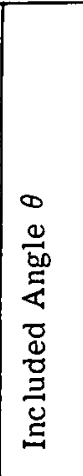 & 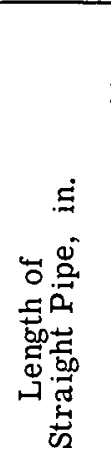 & 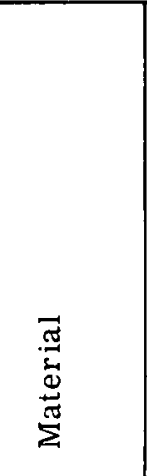 & 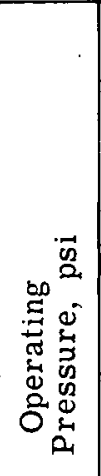 & 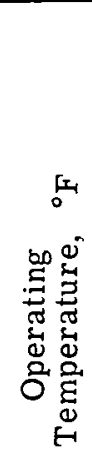 & 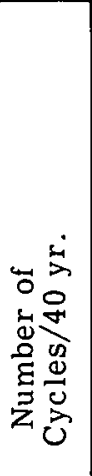 & 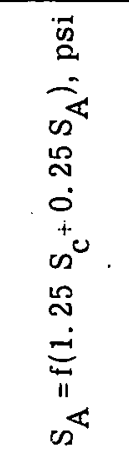 & 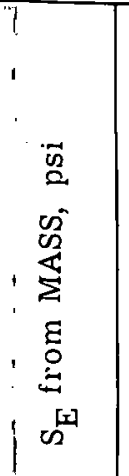 & $\underbrace{\sqrt{4}}_{\infty^{\infty}}$ & 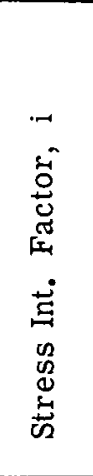 & 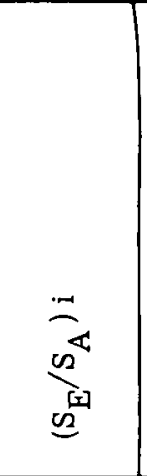 & 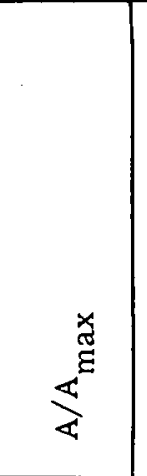 & 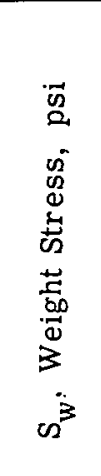 & 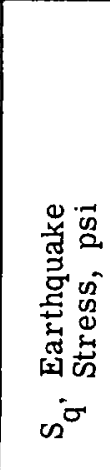 \\
\hline $\begin{array}{l}\text { Pressure Vessel } \\
\text { Nozzle Weld }\end{array}$ & & D-1 & & & & & & & & Sea & & & & & & & 10 & 03089 & & & \\
\hline Straight & 551 & 1 & $261-262$ & 10.75 & 0.593 & & & & 3.0 & $\begin{array}{l}304 \\
304\end{array}$ & 1000 & 552 & 500 & 26.100 & 8116 & 0.3110 & 1.0 & 0.3110 & 0.1585 & $\begin{array}{l}2080 \\
2039\end{array}$ & $\begin{array}{l}2365 \\
2456\end{array}$ \\
\hline Weld & & D-1 & & & & & & & & & & & & & 8796 & 0.3370 & 1.0 & 0.3370 & & 3144 & 3977 \\
\hline Elbow & 552 & 2 & $262-263$ & 10.75 & 0.593 & 18 & 1.8 & $90^{\circ}$ & & 304 & 1000 & 552 & 500 & 26,100 & 12220 & 0.4682 & & 0.4682 & 0.1585 & 1722 & 4606 \\
\hline Weld & & D-1 & & & & & & & & & & & & & 12220 & 0.4682 & 1.0 & 0.4682 & & 1605 & 4606 \\
\hline Straight & 553 & 1 & 263-264 & 10.75 & 0.593 & & & & 39.0 & 304 & 1000 & 552 & 500 & 26,100 & 7878 & 0.3018 & & 0.3018 & 0.1585 & 1549 & 2595 \\
\hline Bend & 554 & 3 & $264-265$ & 10.75 & 0.593 & 48 & 4.8 & $70^{\circ}$ & & 304 & 1000 & 552 & 500 & 26. 100 & 6651 & 0.2548 & & 0.2548 & 0.1585 & 1549 & 2595 \\
\hline Hanger & & D-2 & 265 & & & & & & & & & & & & 4249 & 0.1628 & 1.0 & 0.1628 & & 2721 & 1415 \\
\hline Straight & 555 & 1 & $265-266$ & 10.75 & 0.593 & & & & 111.9 & 304 & 1000 & 552 & 500 & 26,100 & 4565 & 0.1749 & & 0.1749 & 0.1585 & 848 & 1892 \\
\hline Weld & & D-1 & 266 & & & & & & & & & & & & 6412 & 0.2457 & 1.0 & 0.2457 & & 1116 & 3059 \\
\hline Elbow & 556 & 2 & $266-267$ & 10.75 & 0.593 & 18 & 1.8 & $90^{\circ}$ & & 304 & 1000 & 552 & 500 & 26.100 & 7235 & 0.2776 & & 0.2776 & 0.1585 & 1110 & 3580 \\
\hline Weld & & D-1 & & & & & & & & & & & & & 7235 & 0.2776 & 1.0 & 0.2776 & & 982 & 3580 \\
\hline Straight & 557 & 1 & $267-268$ & 10.75 & 0.593 & & & & 156.0 & 304 & 1000 & 552 & 500 & 26.100 & 4765 & 0.1826 & & 0.1826 & 0.1585 & 2575 & 2365 \\
\hline Valve Attachment & & D-1 & & & & & & & & & & & & & 4590 & 0.1759 & 1.0 & 0.1759 & & 1047 & 2365 \\
\hline Valve & 558 & 4 & $268-269$ & 10.75 & 0.593 & & & & 36.0 & 304 & 1000 & 552 & 500 & 26,100 & 2322 & 0.0890 & & 0.0890 & 0.1585 & 1017 & 1198 \\
\hline Valve to Valve Connection & & D-1 & 269 & & & & & & & & & & & & 2322 & 0.0890 & 1.0 & 0.0890 & & 1017 & 1198 \\
\hline Valve & 559 & 4 & $269-270$ & 10.75 & 0.593 & & & & 36.0 & 304 & 1000 & 552 & 500 & 26,100 & 2835 & 0.1086 & & 0.1086 & 0.1585 & 632 & 1270 \\
\hline Valve Attachment & & D-1 & 270 & & & & & & & & & & & & 6968 & 0.2670 & 1.0 & 0.2670 & & 1553 & 3123 \\
\hline Straight & 560 & 1 & $270-271$ & 10.75 & 0.593 & & & & 117.0 & 304 & 1000 & 552 & 500 & 26,100 & 11460 & 0.4391 & & 0.4391 & 0.1585 & 4347 & 3123 \\
\hline $\begin{array}{l}\text { Hanger and } 10-\text { in. } \times 16 \text { in. } \\
\text { Reducer }\end{array}$ & & $D-2,6$ & & & & & & & & Welde & & & & & 11460 & 0.4391 & 1.0 & 0.4391 & & 1370 & \\
\hline Bend & 561 & 3 & $271-272$ & 16.0 & 0.843 & 60 & 3.75 & $90^{\circ}$ & & 304 & 1000 & 552 & 500 & 26.100 & 3923 & 0.1503 & 1.0 & 0.1503 & 0.3549 & 277 & 1303 \\
\hline Straight & 562 & 1 & $272-273$ & 16.0 & 0.843 & & & & 296.0 & 304 & 1000 & 552 & 500 & 26.100 & 3619 & 0.1387 & & 0.1387 & 0.3549 & 277 & 1477 \\
\hline Bend & 563 & 3 & $273-274$ & 16.0 & 0.843 & 60 & 3.75 & $90^{\circ}$ & & 304 & 1000 & 552 & 500 & 26.100 & 1641 & 0.0629 & & 0.0629 & 0.3549 & 190 & 1917 \\
\hline Hanger & & $\mathrm{D}-2$ & 274 & & & & & & & & & & & & 1641 & 0.0629 & 1.0 & 0.0629 & & 190 & 1917 \\
\hline Straight & 564 & 1 & $274-275$ & 16.0 & 0.843 & & & & 6.0 & 304 & 1000 & 552 & 500 & 26,100 & 1656 & 0.0634 & & 0.0634 & 0.3549 & 177 & 1917 \\
\hline Bend & 564 & 3 & $275-276$ & 16.0 & 0.843 & 60 & 3.75 & $90^{\circ}$ & & 304 & 1000 & 552 & 500 & 26,100 & 1656 & 0.0634 & & 0.0634 & 0.3549 & 200 & 1860 \\
\hline 16-in. Run of Tee 277 & 566 & 1 & $276-277$ & 16.0 & 0.843 & & & & 73.0 & 304 & 1000 & 552 & 500 & 26,100 & 1089 & 0.0417 & & 0.1892 & 0.3549 & 48 & 1300 \\
\hline 12 -in. $\times 16$-in. Tee & & D-4 & & & & & & & & & & & & & 3290 & 0.1261 & 1.5 & 0.1892 & & 43 & 1300 \\
\hline 16 -in. Run of Tee 277 & 567 & 1 & $277-278$ & 16.0 & 0.843 & & & & 10.0 & 304 & 1000 & 552 & 500 & 26.100 & 3401 & 0.1303 & & 0.1892 & 0.2242 & 35 & 562 \\
\hline
\end{tabular}




\begin{tabular}{|c|c|c|c|c|c|c|c|c|c|c|c|c|c|c|c|c|c|c|c|c|c|}
\hline $\begin{array}{l}\text { Model Number } 4 \\
\text { Emergency Condenser } \\
\text { Steam (South Side) } \\
\text { (Continued) } \\
\text { Component } \\
\text { or Discontinuity }\end{array}$ & 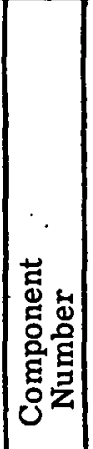 & 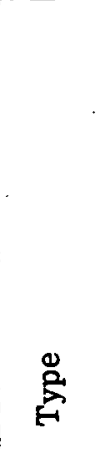 & 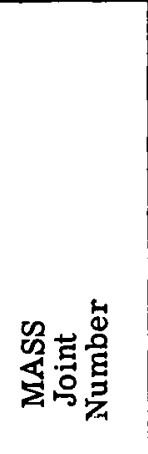 & 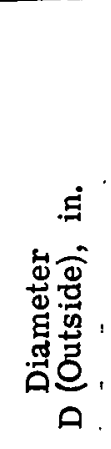 & 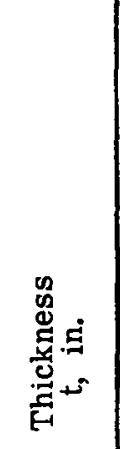 & 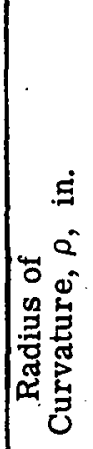 & $\stackrel{*}{\stackrel{*}{Q}}$ & 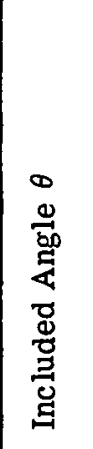 & 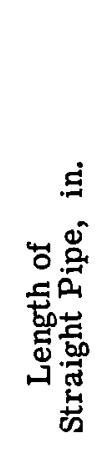 & 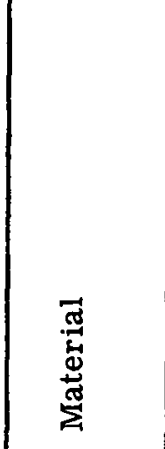 & 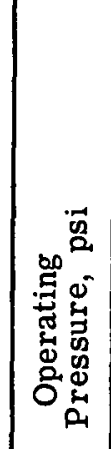 & 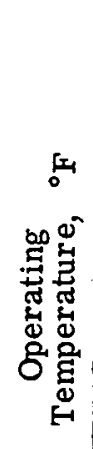 & 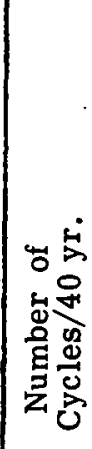 & 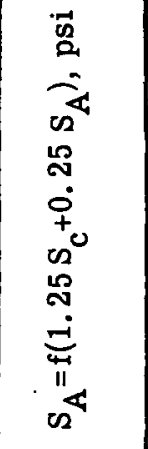 & 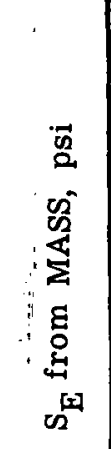 & 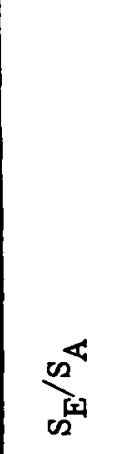 & 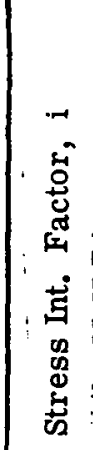 & $\begin{array}{l}\vec{a} \\
\sigma^{4} \\
\sigma^{4}\end{array}$ & $\underbrace{\stackrel{\sharp}{4}}_{4}$ & 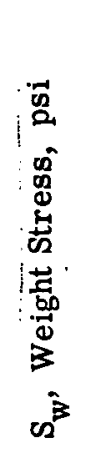 & 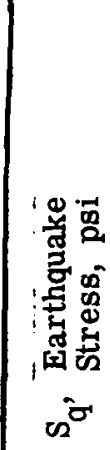 \\
\hline 12 -in. $\times 16$-in. $\mathrm{F}$ & & D-6 & 4 & & & & & & & eld & & & & & 6232 & 0.2388 & 1.5 & .2388 & & 111 & 1374 \\
\hline Elbow & 568 & 2 & $278-279$ & 12.75 & 0.687 & 18 & 1.5 & $90^{\circ}$ & & 304 & 1000 & 552 & 500 & 26,100 & 6232 & 0.2388 & & 0.2388 & 0.2242 & 97 & 1874 \\
\hline Weld & & $D-1$ & 279 & & & & & & & & & & & & 5090 & 0.1950 & 1.5 & 0.1950 & & 63 & 1507 \\
\hline Straight & 569 & 1 & $279-280$ & 12.75 & 0.687 & & & & 66.3 & 304 & 1000 & 552 & 500 & 26,100 & 3148 & 0.1206 & & 0.1206 & 0.2242 & 92 & 1071 \\
\hline Bend & 570 & 3 & $280-281$ & 12.75 & 0.687 & 60 & 5.0 & $90^{\circ}$ & & 304 & 1000 & 552 & 500 & 26,100 & 1954 & 0.0749 & & 0.0749 & 0.2242 & 342 & 1071 \\
\hline Straight & 571 & 1 & 281-282 & 12.75 & 0.687 & & & & 9.38 & 304 & 1000 & 552 & 500 & 26,100 & 2061 & 0.0790 & & 0.0790 & 0.2242 & 420 & 1115 \\
\hline Hanger & & D-2 & 282 & & & & & & & & & & & & 2061 & 0.0790 & 1.5 & 0.0790 & & 420 & 1115 \\
\hline Bend & 572 & 3 & $282-283$ & 12.75 & 0.687 & 60 & 5.0 & $90^{\circ}$ & & 304 & 1000 & 552 & 500 & 26,100 & 3241 & 0.1242 & & 0.1242 & 0.2242 & 208 & 1115 \\
\hline Straight & 573 & 1 & 283-284 & 12.75 & 0.687 & & & & 38.4 & 304 & 1000 & 552 & 500 & 26,100 & 3241 & 0.1242 & & 0.1242 & 0.2242 & 215 & 625 \\
\hline Weld & & $\mathrm{D}-1$ & 284 & & & & & & & & & & & & 4679 & 0.1793 & 1.5 & 0.1793 & & 310 & 903 \\
\hline Elbow & 574 & 2 & $284-285$ & 12.75 & 0.687 & 18 & 1.5 & $90^{\circ}$ & & 304 & 1000 & 552 & 500 & 26,100 & 14715 & 0.1807 & & 0.1807 & 0.2242 & 285 & 1574 \\
\hline Weld & & D-1 & 285 & & & & & & & Welded & & & & & 4717 & 0.1807 & 1.0 & 0.1807 & & 285 & 1574 \\
\hline Straight & 575 & 1 & $285-286$ & 12.75 & 0.687 & & & & 14.5 & A 312,304 & 1000 & 552 & 500 & 26,100 & 2776 & 0.1064 & & 0.1064 & 0.2242 & 182 & 957 \\
\hline Attachment to Condenser & & $\mathrm{D}-1$ & 286 & & & & & & & & & & & & 3674 & 0.1408 & 1.0 & 0.1408 & & 163 & 957 \\
\hline 12-in. Branch of Tee 277 & 576 & 1 & $277-290$ & 12.75 & 0.687 & & & & 84.3 & A312,304 & 1000 & 552 & 500 & 26,100 & 3674 & 0.1408 & & 0.1892 & 0.2242 & 222 & 1969 \\
\hline Bend & 577 & 3 & $290-291$ & 12.75 & 0.687 & 60 & 5.0 & $90^{\circ}$ & & A312,304 & 1000 & 552 & 500 & 26,100 & .2557 & 0.0980 & & 0.0980 & 0.2242 & 566 & 1897 \\
\hline Hanger & & $\mathrm{D}-2$ & 291 & & & & & & & & & & & & 2557 & 0.0980 & 1.0 & 0.0980 & & 566 & 1897 \\
\hline Straight & 578 & 1 & $291-292$ & 12.75 & 0.687 & & & & 9.38 & A312,304 & 1000 & 552 & 500 & 26,100 & ' 2555 & 0.0979 & & 0.0979 & 0.2242 & 492 & 1897 \\
\hline Bend & 579 & 3 & $292-293$ & 12.75 & 0.687 & 60 & 5.0 & $90^{\circ}$ & & A312, 304 & 1000 & 552 & 500 & 26,100 & .3320 & 0.1272 & & 0.1272 & 0.2242 & 492 & 1884 \\
\hline Straight & 580 & 1 & 293-294 & 12.75 & 0.687 & & & & .17 .6 & A312, 304 & 1000 & 552 & 500 & 26,100 & 3541 & 0.1357 & & 0.1357 & 0.2242 & 294 & 647 \\
\hline Weld & & $D-1$ & & & & & & & & & & & & & 4981 & 0.1908 & 1.0 & 0.1908 & & 488 & 1081 \\
\hline Elbow & 581 & 2 & $294-295$ & 12.75 & 0.687 & 18 & 1.5 & $90^{\circ}$ & & A312,304 & 1000 & 552 & $\mid 500$ & 26,100 & 5824 & 0.2231 & & 0.2231 & 0.2242 & 488 & 2065 \\
\hline Weld & & $D-1$ & & & & & & & & & & & & & 5824 & 0.2231 & 1.0 & 0.2231 & & 447 & 2065 \\
\hline Straight & 582 & 1 & $295-296$ & 12.75 & 0.687 & & & & 14.5 & A312, 304 & 1000 & 552 & 500 & 26,100 & ' 3309 & 0.1268 & & 0.1268 & 0.2242 & 346 & 1157 \\
\hline Attachment to $\mathrm{C}$ & & $\mathrm{D}-1$ & 296 & & & & & & & & & & & & 2917 & 0.1118 & 1.0 & 0.1118 & & 346 & 1157 \\
\hline
\end{tabular}




\begin{tabular}{|c|c|c|c|c|c|c|c|c|c|c|c|c|c|c|c|c|c|c|c|c|c|}
\hline $\begin{array}{l}\text { Model Number } 5 \\
\text { Recirculation Loop No. } 1 \\
\text { (Main Line) } \\
\text { Component } \\
\text { or Discontinuity } \\
\end{array}$ & 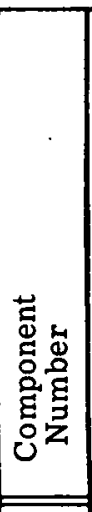 & 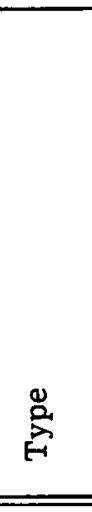 & 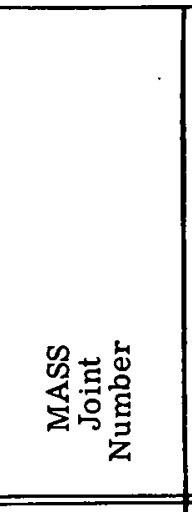 & 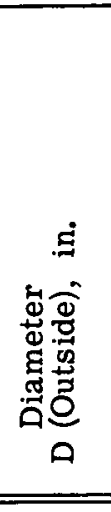 & 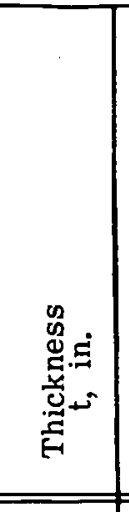 & 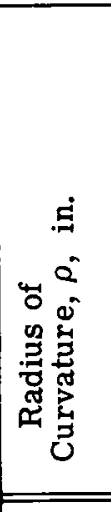 & $\stackrel{*}{a}$ & 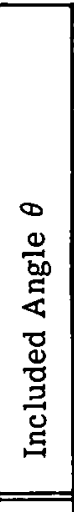 & 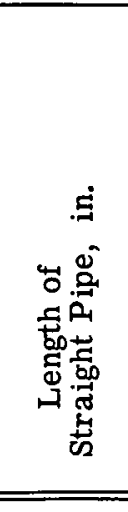 & 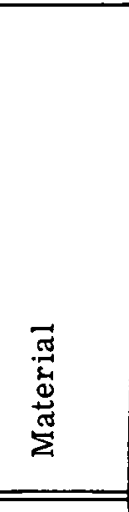 & 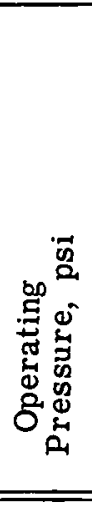 & 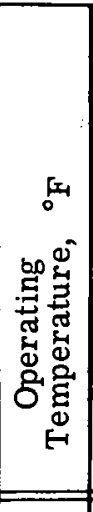 & 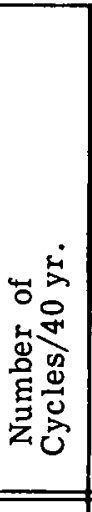 & 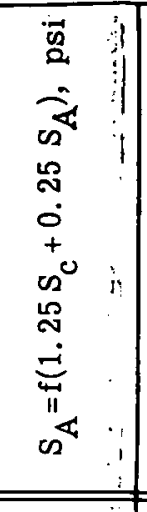 & 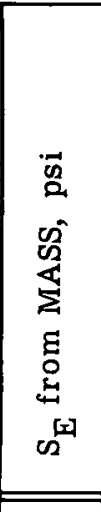 & $\underset{\sqrt{4}}{\sigma^{4}}$ & 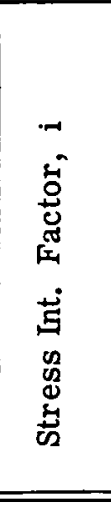 & 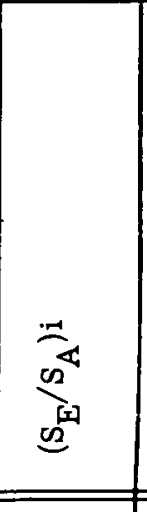 & 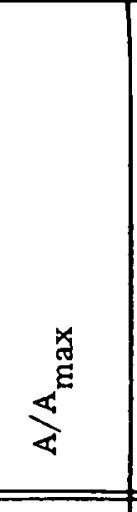 & 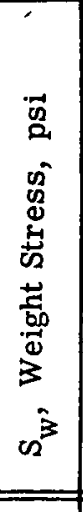 & 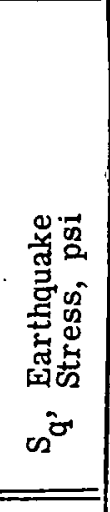 \\
\hline Pressure Vessel & & & & & & & & & & & & & & & & & & & & & \\
\hline Nozzle:Weld & & D-1 & 2 & & & & & & & Wow & & & 260 & 274001 & $\begin{array}{r}821 \\
1533\end{array}$ & $\begin{array}{l}0.315 \\
0.0587\end{array}$ & 1.0 & 0.0315 & 1.0 & $\begin{array}{l}200 \\
745\end{array}$ & $\begin{array}{l}1285 \\
1285\end{array}$ \\
\hline $\begin{array}{l}\text { Bend } \\
\text { Weld }\end{array}$ & 601 & $\begin{array}{c}3 \\
D-1\end{array}$ & $\begin{array}{l}2-3 \\
3\end{array}$ & 25.99 & 0.982 & 39 & 1.5 & $90^{\circ}$ & & 316 & 1015 & 555 & 360 & 27,400 & $\begin{array}{l}1533 \\
1533\end{array}$ & $\begin{array}{l}0.0587 \\
0.0587\end{array}$ & 1.0 & $\begin{array}{l}0.0587 \\
0.0587\end{array}$ & 1.0 & $\begin{array}{l}745 \\
189\end{array}$ & $\begin{array}{r}2285 \\
533\end{array}$ \\
\hline $\begin{array}{l}\text { Weld. } \\
\text { Straight (Run of Tee 37) }\end{array}$ & 602 & 1 & $3-37$ & 25.99 & 1.875 & & & & 19.5 & 316 & 1015 & 555 & 360 & 27,400 & 419 & 0.0161 & & 0.0587 & 0.8569 & 200 & 172 \\
\hline Straight (Run of Tee 37) & 603 & 1 & $37-38$ & 25.99 & 1.875 & & & & 209.5 & 316 & 1015 & 555 & 360 & 27,400 & 505 & 0.0193 & & 0.0236 & 0.8569 & 252 & 693 \\
\hline Weld: & & D-1 & 38 & & & & & & & & & & & & 749 & 0.0287 & 1.0 & 0.0287 & & 140 & 1192 \\
\hline Straight & 604 & $i$ & $38-35$ & 25.99 & 0.982 & & & & 23.0 & 316 & 1015 & 555 & 360 & 27,400 & 749 & 0.0287 & & 0.0287 & 1.0 & 241 & 1192 \\
\hline Hanger & & $\mathrm{D}-2$ & 35 & & & & & & & & & & & & 735 & 0.0282 & 1.0 & 0.0282 & & 220 & 1145 \\
\hline Straight & 604 & 1 & $35-4$ & 25.99 & 0.982 & & & & 103.0 & 316 & 1015 & 555 & 360 & 27,400 & 735 & 0.0282 & & 0.0282 & 1.0 & 220 & 1145 \\
\hline Valve Attachment & & D-1 & 4 & & & & & & & & & & & & 676 & 0.0259 & 1.0 & 0.0259 & & 128 & 951 \\
\hline Valve & 606 & 4 & $4-5$ & 25.99 & 6.5 & & & & 60.0 & 316 & 1015 & 555 & 360 & 27,400 & 194 & 0.0074 & & 0.0074 & 0.2923 & 37 & 274 \\
\hline Valve Attachment & & $D-1$ & 5 & & & & & & & & & & & & 1476 & 0.0566 & 1.0 & 0.0566 & & 23 & 725 \\
\hline Elbow & 607 & 2 & $5-6$ & 25.99 & 0.982 & 38.9 & 1.5 & $90^{\circ}$ & & 316 & 1015 & 555 & 360 & 27,400 & 1476 & 0.0566 & & 0.0566 & 1.0 & 167 & 894 \\
\hline Weld & & $D-1$ & 6 & & & & & & & & & & & & 355 & 0.0136 & 1.0 & 0.0136 & & 132 & 894 \\
\hline Straight & 608 & 1 & $6-7$ & 25.99 & 0.982 & & & & 10.6 & 316 & 1015 & 555 & 360 & 27,400 & 232 & 0.0089 & & 0.0089 & 1.0 & 58 & 529 \\
\hline Thermocouple & & D-3 & Bet. $6 \& 7$ & & & & & & & & & & & & & & & & & & \\
\hline 1 in. Pres. Sensing Line & & $D-3$ & Bet. $6 \& 7$ & & & & & & & & & & & & & & & & & & \\
\hline $\begin{array}{l}\text { Blanked-Off } \\
\text { Decontamination Nozzle }\end{array}$ & & D-5 & Bet. $6 \& 7$ & & & & & & & & & & & & & & & & & & \\
\hline $\begin{array}{l}\text { Weld } \\
\text { Elbow }\end{array}$ & 609 & $\begin{array}{c}\mathrm{D}-1 \\
2\end{array}$ & $7-8$ & 25.99 & 0.982 & 25.9 & 1.0 & $90^{\circ}$ & & 316 & 1015 & 555 & 360 & 27,400 & $\begin{array}{r}365 \\
1341\end{array}$ & $\begin{array}{l}0.0140 \\
0.0514\end{array}$ & 1.0 & $\begin{array}{l}0.0140 \\
0.0514\end{array}$ & 1.0 & $\begin{array}{l}12 \\
15\end{array}$ & $\begin{array}{l}1280 \\
1402\end{array}$ \\
\hline Pump Attachment & & D-1 & 8 & & & & & & & & & & & & 1341 & 0.0541 & 1.0 & 0.0514 & & 478 & 1402 \\
\hline Pump & 610 & $\mathbf{5}$ & $8-10$ & & & & & & & & & & & & 1232 & 0.0472 & 1.0 & 0.0472 & & & \\
\hline Pump Attachment & & D-1 & 10 & & & & & & & & & & & & & & & & 10 & $\begin{array}{l}172 \\
21\end{array}$ & 643 \\
\hline $\begin{array}{l}\text { Sector of Elbow } \\
\text { Thermocouple }\end{array}$ & 611 & $\begin{array}{c}2 \\
D-3\end{array}$ & $\begin{array}{c}10-17 \\
\text { Bet. 10\& 17 }\end{array}$ & 25.99 & 0.982 & 40 & 1.5 & $48^{\circ}$ & & 316 & 1055 & | 555 & 360 & 27,400 & 2190 & 0.0839 & & 0.0839 & 1.0 & $211 \mid$ & 643 \\
\hline 1 in. Pres. Sensing Line & & D-3 & Bet. 10\& 17 & & & & & & & & & & & & & & & & & & \\
\hline Bypass Connection & & D-4 & 17 & & & & & & & & & & & & 2190 & 0.0839 & 1.875 & 0.1573 & & 213 & 674 \\
\hline Sector of Elbow & 612 & 2 & $17-11$ & 25.89 & 0.982 & 42 & 1.6 & $26^{\circ}$ & & 316 & 1055 & 555 & 360 & 27,400 & 1657 & 0.0635 & & 0.0635 & 1.0 & 191 & 674 \\
\hline Valve Attachment & & D-1 & 11 & & & & & & & & & & & & 1657 & 0.0635 & 1.875 & 0.0635 & & 32 & 506 \\
\hline Valve & 613 & 4 & $11-12$ & 25.99 & 0.982 & & & & 75.0 & 316 & 1055 & 555 & 360 & 27,400 & 273 & 0.0105 & & 0.0105 & & 25 & 155 \\
\hline Valve Attachment & & D-1 & 12 & & & & & & & & & & & & 909 & 0.0348 & 1.875 & 0.0348 & & 86 & 539 \\
\hline Straight & 614 & 1 & $12-28$ & 25.99 & 0.982 & & & & 7.5 & 316 & 1055 & 555 & 360 & 27,400 & 909 & 0.0348 & & 0.0348 & 1.0 & 85 & 540 \\
\hline
\end{tabular}




\begin{tabular}{|c|c|c|c|c|c|c|c|c|c|c|c|c|c|c|c|c|c|c|c|c|c|}
\hline $\begin{array}{l}\text { Model Number 5 } \\
\text { Recirculation Loop No. } 1 \\
\text { (Main Line) } \\
\text { (Continued) } \\
\text { Component } \\
\text { or Discontinuity } \\
\text { or Discolit }\end{array}$ & 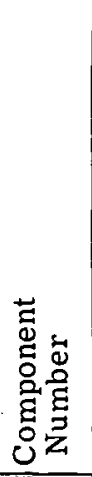 & 产 & 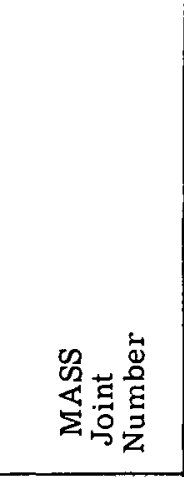 & 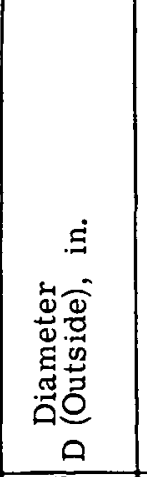 & 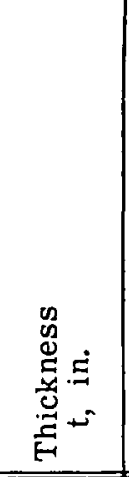 & 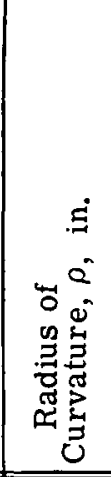 & $\stackrel{*}{a}$ & 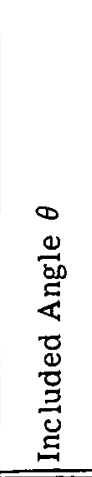 & 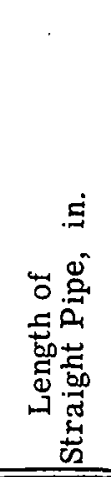 & 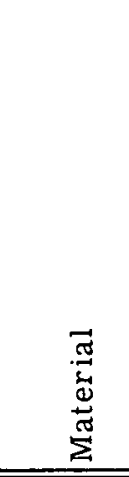 & 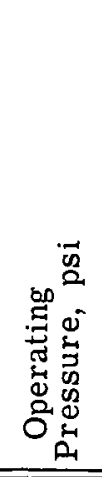 & 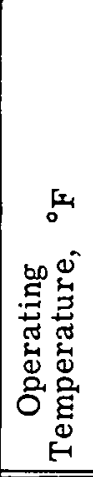 & 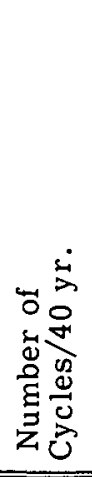 & 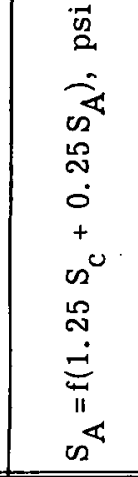 & 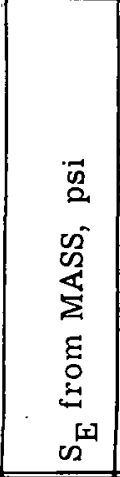 & 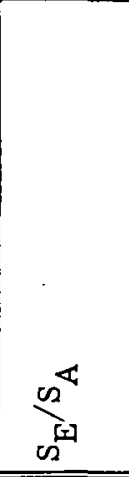 & 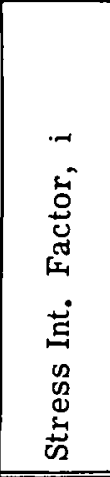 & 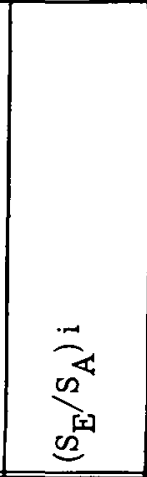 & $\sum_{i}^{\infty}$ & 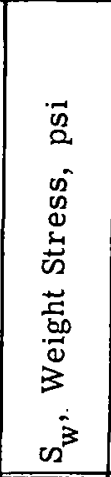 & 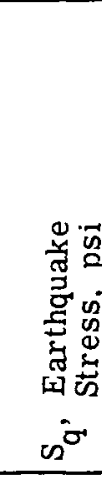 \\
\hline $\begin{array}{l}\text { Bypass Connection } \\
\text { Straight } \\
\text { Flow Meter }\end{array}$ & 615 & $\begin{array}{c}D-4 \\
1 \\
D-3 a\end{array}$ & \begin{tabular}{|c|}
28 \\
$28-36$ \\
Bet. $28 \& 36$
\end{tabular} & 25.99 & 0.982 & & & & 50.5 & $\begin{array}{l}\text { Seam- } \\
\text { less } \\
316\end{array}$ & 1055 & 555 & 360 & 27.400 & \begin{tabular}{|l|}
905 \\
905 \\
\end{tabular} & $\begin{array}{l}0.0347 \\
0.0347\end{array}$ & 1.875 & \begin{tabular}{l|}
0.0651 \\
0.0347
\end{tabular} & 1.0 & \begin{tabular}{l|}
86 \\
86
\end{tabular} & $\begin{array}{l}542 \\
542\end{array}$ \\
\hline Hanger & & D-2 & 36 & & & & & & & & & & & & 878 & 0.0336 & 1.875 & 0.0336 & 1.0 & 86 & 532 \\
\hline Straight & 616 & 1 & $36-40$ & 25.99 & 0.982 & & & & 113.2 & 316 & 1055 & 555 & 360 & 27,400 & 878 & 0.0336 & & 0.0336 & 1.0 & 156 & 525 \\
\hline Straight & 616 & 1 & $40-39$ & 25.99 & 0.982 & & & & 19.5 & 316 & 1055 & 555 & 360 & 26,100 & 817 & 0.0313 & & 0.0313 & 1.0 & 169 & 525 \\
\hline Straight & 616 & 1 & $39-13$ & 25.99 & 0.982 & & & & 19.5 & 316 & 1055 & 555 & 360 & 26,100 & 807 & 0.0309 & & 0.0309 & 1.0 & 169 & 538 \\
\hline Weld & & $\mathrm{D}-1$ & 13 & & & & & & & & & & & & 1829 & 0.0701 & 1.875 & 0.0701 & & 185 & 673 \\
\hline Elbow & 617 & 2 & 13-14 & 25.99 & 0.982 & 40 & 1.5 & $76^{\circ}$ & & 316 & 1055 & 555 & 360 & 26,100 & 1829 & 0.0701 & & 0.0701 & 1.0 & \begin{tabular}{|l|l|}
389 \\
\end{tabular} & 673 \\
\hline Weld & & $\mathrm{D}-1$ & 14 & & & & & & & & & & & & 918 & 0.0352 & 1.875 & 0.0352 & & 186 & 659 \\
\hline Straight & 618 & 1 & $14-15$ & 25.99 & 0.982 & & & & 31.4 & 316 & 1055 & 555 & 360 & 26,100 & 924 & 0.0354 & & 0.0354 & 1.0 & 85 & 659 \\
\hline Pres. Vessel Nozzle Weld & & $\mathrm{D}-1$ & 15 & & & & & & & & & & & & 924 & 0.0354 & 1.875 & 0.0354 & & 89 & 441 \\
\hline \multicolumn{22}{|l|}{$\begin{array}{l}\text { Model Number } 5 \\
\text { Recirculation Loop } 1 \text { - } \\
\text { Bypass Line }\end{array}$} \\
\hline Straight & 619 & 1 & $17-18$ & 2. 374 & 0.218 & & & & 5.0 & 316 & 1055 & 555 & 360 & 26,100 & 132 & 0.0051 & & 0.0051 & 0.0065 & 1402 & 2462 \\
\hline Weld & & $D-1 a$ & 18 & & & & & & & & & & & & 152 & 0.0058 & 1.3 & 0.0076 & & 847 & 3197 \\
\hline Elbow & 620 & 2 & $18-19$ & 2.374 & 0.218 & 3.0 & 1.5 & $88^{\circ}$ & & 316 & 1055 & 555 & 360 & 26,100 & 162 & 0.0063 & & 0.0063 & 0.0065 & 850 & 3208 \\
\hline Weld & & $D-1 a$ & 19 & & & & & & & & & & & & 165 & 0.0063 & 1,3 & 0,0082 & & 922 & 3208 \\
\hline Straight & 621 & 1 & $19-20$ & 2.374 & 0.218 & & & & 26.7 & 316 & 1055 & 555 & 360 & 26,100 & 134 & 0.0051 & & 0.0051 & 0.0065 & 716 & 2470 \\
\hline Weld & & D-1a & 20 & & & & & & & & & & & & 93 & 0.0036 & 1.3 & 0.0047 & & 500 & 1602 \\
\hline Straight & 622 & 1 & $20-21$ & 2.374 & 0.218 & & & & 2.5 & 316 & 1055 & 555 & 360 & 26,100 & 93 & 0.0036 & & 0.0036 & 0.0065 & 500 & 1602 \\
\hline $\begin{array}{l}\text { Branch to Decontamination } \\
\text { Nozzle }\end{array}$ & & $\mathrm{D}-4$ & 21 & & & & & & & & & & & & 83 & 0.0032 & 1.04 & 0.0042 & & 482 & 1482 \\
\hline Straight & 623 & 1 & $21-22$ & 2.374 & 0.218 & & & & 33.6 & 316 & 1055 & 555 & 360 & 26.100 & 83 & 0.0032 & & 0.0032 & 0.0065 & 482 & 1482 \\
\hline Weld & & $D-1 a$ & 22 & & & & & & & & & & & & 71 & 0.0027 & 1.3 & 0.0035 & & \begin{tabular}{|l|}
470 \\
\end{tabular} & 754 \\
\hline Elbow & 624 & 2 & $22-23$ & 2.374 & 0.218 & 3.0 & 1.5 & $90^{\circ}$ & & 316 & 1055 & 555 & 360 & 26,100 & 83 & 0.0032 & & 0.0032 & 0.0065 & 470 & 754 \\
\hline Weld & & D-1a & 23 & & & & & & & & & & & & 83 & 0.0032 & 1.3 & 0.0042 & & 513 & 689 \\
\hline Straight & 625 & 1 & $23-24$ & 2.374 & 0.218 & & & & 6.0 & 316 & 1055 & 555 & 360 & 26,100 & 63 & 0.0024 & & 0.0013 & 0.0065 & 391 & 764 \\
\hline Valve Attachment & & D-1a & 24 & & & & & & & & & & & & 58 & 0.0022 & 1.3 & 0.0029 & & 325 & 764 \\
\hline Valve & 626 & 4 & $24-25$ & 2. 374 & 0.6 & & & & 7.5 & 316 & 1055 & 555 & 360 & 26,100 & 34 & 0.0013 & & 0.0024 & 0.0024 & 192 & 516 \\
\hline Valve Attachment & & $D-1 a$ & 25 & & & & & & & & & & & & 52 & 0.0020 & 1.3 & 0.0026 & & 148 & 872 \\
\hline Straight & 627 & 1 & $25-26$ & 2. 374 & 0.218 & & & & 85.4 & 316 & 1055 & 555 & 360 & 26,100 & 81 & 0.0031 & & 0.0031 & 0.0065 & 251 & 1058 \\
\hline Weld & & $D-1 a$ & 2.6 & & & & & & & & & & & & 106 & 0.0041 & 1.3 & 0.0053 & & 953 & 1272 \\
\hline Elbow & 628 & 2 & $26-27$ & 2.374 & 0.218 & 3.0 & 1.5 & $90^{\circ}$ & & 316 & 1055 & 555 & 360 & 26,100 & 106 & 0.0041 & & 0.0041 & 0.0065 & 1257 & 1397 \\
\hline Weld & & D-1a & 27 & & & & & & & & & & & & 83 & 0.0032 & 1.3 & 0.0042 & & 431 & 1397 \\
\hline Straight & 629 & 1 & $27-28$ & 2.374 & 0.218 & & & & 20.0 & 316 & 1055 & 555 & 360 & 26,100 & 115 & 0.0044 & & 0.0044 & 0.0065 & 4413 & 1889 \\
\hline
\end{tabular}




\begin{tabular}{|c|c|c|c|c|c|c|c|c|c|c|c|c|c|c|c|c|c|c|c|c|c|}
\hline $\begin{array}{l}\qquad \ddots^{2} \\
\text { Model Number } 5 \\
\text { Emergency Condenser } \\
\text { Condensate (South Side) } \\
\text { Component } \\
\text { or Discontinuity } \\
\end{array}$ & 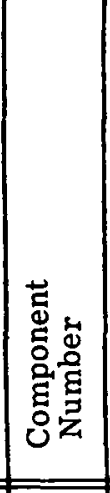 & $\sum_{\xi}^{\infty}$ & 号产 & 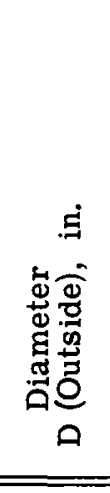 & 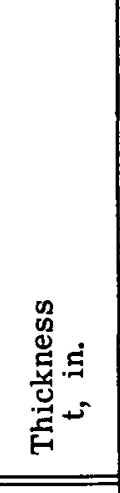 & 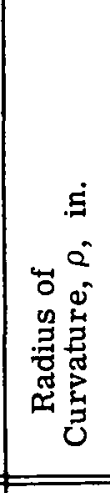 & $\stackrel{*}{a}$ & 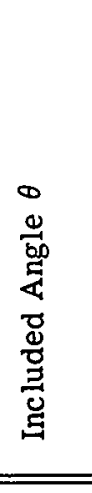 & 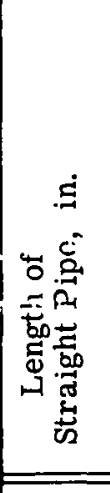 & 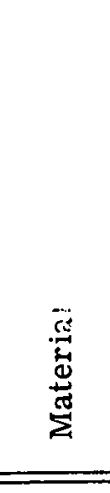 & 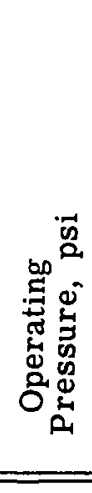 & 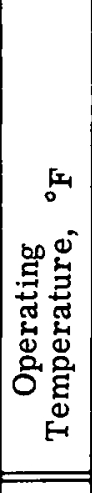 & 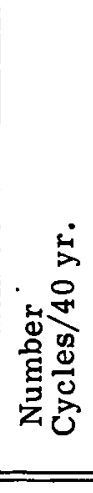 & 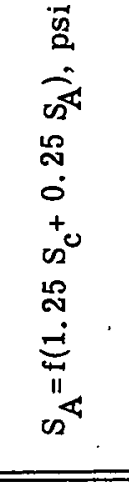 & 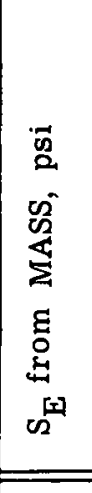 & 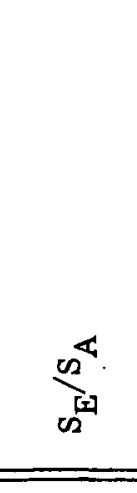 & 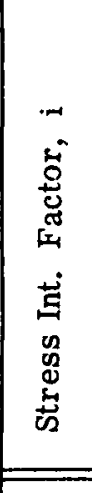 & 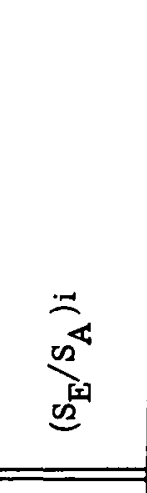 & 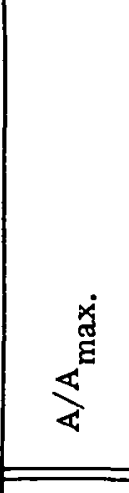 & 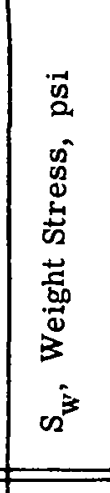 & 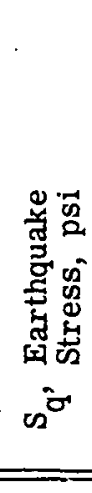 \\
\hline $10 \mathrm{in.} \times 26$ in. Tee in & & & & & & & & & & 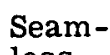 & & & & & & & & & & & \\
\hline Recirculation Line 1 & & D-4 & 37 & & & & & & & less & & & & & 4159 & 0.1518 & 1.22 & 0.1852 & & 4835 & 3329 \\
\hline Straight & 652 & 1 & $37-52$ & 10.75 & 0.593 & & & & \begin{tabular}{|l|l} 
& 51.3 \\
$r$
\end{tabular} & 304 & 1000 & 157 & 500 & 27,400 & 4159 & 0.1518 & & 0.1852 & 0.1585 & 2070 & 3329 \\
\hline Valve Attachment & & $D-1$ & 52 & & & & & $\cdots$ & & & & & & & 3389 & 0.1237 & 1.0 & 0.1237 & & 1377 & 1397 \\
\hline Valve & 653 & 4 & $52-53$ & 10.75 & 2.5 & & & & 26.0 & 304 & 1000 & 157 & 500 & 27,400 & 1379 & 0.0503 & & 0.0503 & 0.0582 & 810 & 930 \\
\hline Valve Attachment & & $D-1$ & 53 & & & & & & & & & & & & 3115 & 0.1137 & 1.0 & 0.1137 & & 1992 & 1070 \\
\hline Straight & 654 & 1 & 53-54 & 10.75 & 0.593 & & & & 75.0 & 304 & 1000 & 157 & 500 & 27,400 & 3115 & 0.1137 & & 0.1137 & 0.1585 & 588 & 1319 \\
\hline Weld & & $D-1$ & 54 & & & & & & & & & & & & 4748 & 0.1733 & 1.0 & 0.1733 & & 1058 & 2413 \\
\hline Elbow & 655 & 2 & $54-55$ & 10.75 & 0.593 & 15 & 1.5 & $90^{\circ}$ & & 304 & 1000 & 157 & 500 & 27,400 & 4748 & 0.1733 & & 0.1733 & 0.1585 & 436 & 3020 \\
\hline Weld & & $D-1$ & 55 & & & & & & & & & & & & 3939 & 0.1438 & 1.0 & 0.4380 & & 434 & 3020 \\
\hline Straight & 656 & 1 & $55-56$ & 10.75 & 0.593 & & & & 85.7 & 304 & 1000 & 157 & 500 & 27,400 & 2627 & 0.0958 & & 0.0958 & 0.1585 & 447 & 1654 \\
\hline Weld & & $D-1$ & 56 & & & & & & & & & & & & 3442 & 0.1256 & 1.0 & 0.1256 & & 476 & 2209 \\
\hline Elbow & 657 & 2 & $56-57$ & 10.75 & 0.593 & 15 & 1.5 & $90^{\circ}$ & & 304 & 1000 & 157 & 500 & 27,400 & 4451 & 0.1624 & & 0.1624 & 0.1585 & 553 & 2209 \\
\hline Weld & & $D-1$ & 57 & & & & & & & & & & & & 4451 & 0.1624 & 1.0 & 0.1624 & & 380 & 1547 \\
\hline Straight & 658 & 1 & $57-58$ & 10.75 & 0.593 & & & & 71.5 & 304 & 1000 & 157 & 500 & 27,400 & 2529 & 0.0923 & & 0.0923 & 0.1585 & 1280 & 868 \\
\hline Weld & & $D-1$ & 58 & & & & & & & & & & & & 2466 & 0.0900 & 1.0 & $0.0900 \mid$ & & 2309 & 594 \\
\hline Elbow & 659 & 2 & $58-59$ & 10.75 & 0.593 & 15 & 1.5 & $90^{\circ}$ & & 304 & 1000 & 157 & 500 & 27,400 & 2466 & 0.0900 & & $0.0900 \mid$ & 0.1585 & 1744 & 661 \\
\hline Weld & & D-1 & 59 & & & & & & & & & & & & 1546 & 0.0571 & 1.0 & 0.0571 & & 1747 & 661 \\
\hline Straight & 660 & 1 & $59-60$ & 10.75 & 0.593 & & & & \begin{tabular}{|l|}
10.9 \\
\end{tabular} & 304 & 1000 & 157 & 500 & 27,400 & 928 & 0.0339 & & 0.0339 & 0.1585 & 1793 & 362 \\
\hline Weld and Hanger & & $\mathrm{D}-1 \& 2$ & 60 & & & & & & & & & & & & 826 & 0.0301 & 1.0 & 0.0301 & & 1984 & 554 \\
\hline Elbow & 661 & 2 & $60-61$ & 10.75 & 0.593 & 15 & 1.5 & $90^{\circ}$ & & 304 & 1000 & $\mid 157$ & 500 & 27,400 & 1060 & 0.0387 & & 0.0387 & 0.1585 & 3724 & 761 \\
\hline Weld & & $\mathrm{D}-1$ & 61 & & & & & & & & & & & & 1060 & 0.0387 & 1.0 & 0.0387 & & 2037 & 761 \\
\hline Stralght & 662 & 1 & $61-62$ & 10.75 & 0.593 & & & & 243.0 & 304 & 1000 & 157 & 500 & 27,400 & 3179 & 0.1160 & & 0.1160 & 0.1585 & 1135 & 2729 \\
\hline Valve Connection & & D-1 & 62 & & & & & & & & & & & & 3179 & 0.1160 & 1.0 & 0.1160 & & 804 & 2729 \\
\hline Valve & 663 & 4 & $62-63$ & 10.75 & 2.5 & & & & 33.0 & 304 & 1000 & 157 & 500 & 27,400 & 401 & 0.0146 & & 0.0146 & 0.0582 & 120 & 2449 \\
\hline Valve Connection & & D-1 & 63 & & & & & & & & & & & & 760 & 0.0277 & 1.0 & 0.0277 & & 295 & 4268 \\
\hline Straight & 664 & 1 & $63-64$ & 10.75 & 0.593 & & & & 28.0 & 304 & 1000 & 157 & 500 & $27,4,00$ & 760 & 0.0277 & & 0.0277 & 0.1585 & 39 & 4268 \\
\hline Bend & 665 & 3 & $64-65$ & 10.75 & 0.503 & 47.6 & 4.8 & $46^{\circ}$ & & 304 & 1000 & 157 & 500 & 27,400 & 633 & 0.0231 & & 0.0231 & 0.1585 & 147 & 3505 \\
\hline
\end{tabular}




\begin{tabular}{|c|c|c|c|c|c|c|c|c|c|c|c|c|c|c|c|c|c|c|c|c|c|}
\hline $\begin{array}{l}\text { Model Number } 5 \\
\text { Emerency Condenser } \\
\text { Condensate (South Side) } \\
\text { (Continued) } \\
\text { Component } \\
\text { or Discontinulty } \\
\end{array}$ & 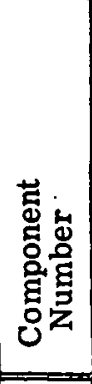 & 产 & 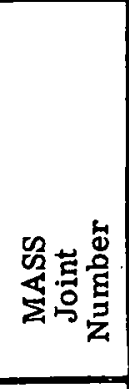 & 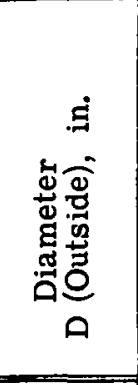 & 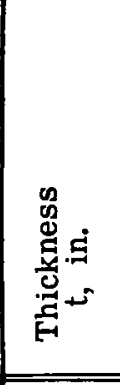 & 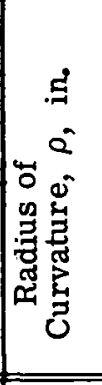 & $\stackrel{\stackrel{*}{e}}{a}$ & 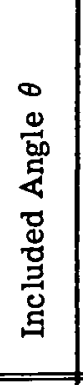 & 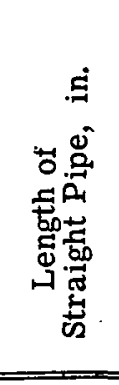 & 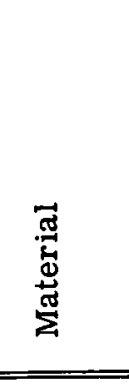 & 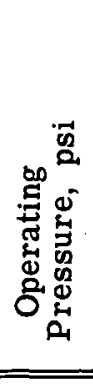 & 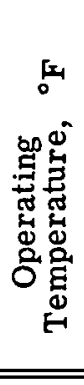 & 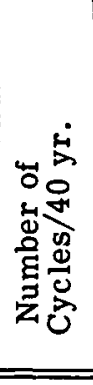 & 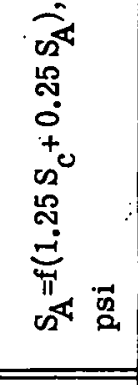 & 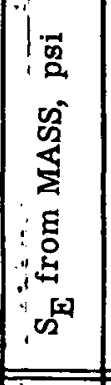 & $\underbrace{\sqrt{4}}_{\infty}$ & 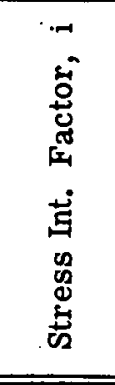 & 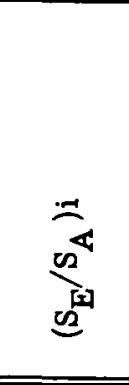 & 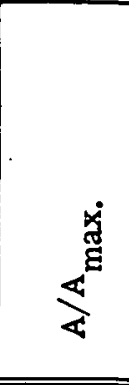 & 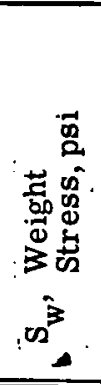 & 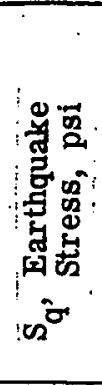 \\
\hline Straight & 666 & & & 10.75 & 0.593 & & & & 174.4 & $\begin{array}{l}\text { Seam- } \\
\text { less } \\
304\end{array}$ & 1000 & 157 & 500 & 27.400 & 806 & 0.0294 & & 0.0294 & 0.1585 & & \\
\hline $\begin{array}{l}\text { Straight } \\
\text { Bend }\end{array}$ & 667 & $\begin{array}{l}1 \\
3\end{array}$ & $\begin{array}{l}03-00 \\
66-67\end{array}$ & 10.75 & $\begin{array}{l}0.593 \\
\end{array}$ & 48.2 & 4.8 & $90^{\circ}$ & 117.7 & & 1000 & 157 & 500 & 27,400 & 806 & 0.0294 & & $\begin{array}{l}0.0294 \\
0.0294\end{array}$ & 0.1585 & $\begin{array}{r}2481 \\
1489\end{array}$ & $\begin{array}{l}3804 \\
3864\end{array}$ \\
\hline Hanger & & D-2 & 67 & & & & & & & & & & & & 258 & 0.0094 & 1.0 & 0.0094 & & 1489 & 1655 \\
\hline Straight & 668 & 1 & $67-68$ & 10.75 & 0.593 & & & & 18.0 & 304 & 1000 & 157 & 500 & 27,400 & 258 & 0.0094 & & 0.0094 & 0.1585 & 693 & 1672 \\
\hline Bend & 669 & 3 & $68-69$ & 10.75 & 0.593 & 49.0 & 4.5 & $90^{\circ}$ & & 304 & 1000 & 157 & 500 & 27,400 & 1019 & 0.0372 & & 0.0372 & 0.1585 & 391 & 2094 \\
\hline Straight & 670 & 1 & $69-70$ & 10.75 & 0.593 & & & & 252.2 & 304 & 1000 & 157 & 500 & 27,400 & 1328 & 0.0485 & & 0.0485 & 0.1585 & 583 & 2094 \\
\hline Bend & 671 & 3 & $70-71$ & 10.75 & 0.583 & 48.0 & 4.8 & $90^{\circ}$ & & 304 & 1000 & 157 & 500 & 27,400 & $\mid$\begin{tabular}{|l|}
$\mid 1415$ \\
\end{tabular} & 0.0516 & & 0.0516 & 0.1585 & 1287 & 1642 \\
\hline Hanger & & D-2 & 71 & & & & & & & & & & & & \begin{tabular}{|l|}
1415 \\
\end{tabular} & 0.0516 & 1.0 & 0.0516 & & 1287 & 1015 \\
\hline Straight & 672 & 1 & 71-72 & 10.75 & 0.593 & & & & 24.0 & 304 & 1000 & 157 & 500 & 27,400 & \begin{tabular}{|l|}
1549 \\
\end{tabular} & 0.0565 & & 0.0565 & 0.1585 & 698 & 1264 \\
\hline Bend & 673 & 3 & $72-73$ & 10.75 & 0.593 & 48.0 & 4.8 & $90^{\circ}$ & & 304 & 1000 & 157 & 500 & 27,400 & 1711 & 0.0624 & & 0.0674 & 0.1585 & 588 & 2210 \\
\hline Straight & 674 & 1 & $73-74$ & 10.75 & 0.593 & & & & 84.0 & 304 & 1000 & 157 & 500 & 27,400 & \begin{tabular}{|l|l|}
1812 \\
\end{tabular} & 0.0625 & & 0.0625 & 0.1585 & 569 & 2210 \\
\hline Bend & 675 & 3 & $74-75$ & 10.75 & 0.593 & 48 & 4.8 & $90^{\circ}$ & & 304 & 1000 & 157 & 500 & 27,400 & 2078 & 0.0758 & & 0.0758 & 0.1585 & 831 & 2153 \\
\hline Hanger & & D-2 & 75 & & & & & & & & & & & & 2051 & 0.0749 & 1.0 & 0.0749 & & 831 & 1635 \\
\hline Branch of Tee 76 & 676 & 1 & $75-76$ & 10.75 & 0.593 & & & & 78.0 & 304 & 1000 & 157 & 500 & 27,400 & 2163 & 0.0789 & & 0.1231 & & 273 & 2762 \\
\hline 8 in. $\times 10$ in. Tee & & D-4 & 76 & & & & & & & & & & & & 2318 & 0.0846 & 1.455 & 0.1231 & & 1140 & 4979 \\
\hline Run of Tee 76 & 677 & 1 & $76-77$ & 8.624 & 0.5 & & & & 75.6 & 304 & 1000 & 157 & 500 & 27,400 & 2318 & 0.0846 & & 0.1231 & 0.1007 & 421 & 4979 \\
\hline Bend & 678 & 3 & $77-78$ & 8.624 & 0.5 & 48 & 6.0 & $90^{\circ}$ & & 304 & 1000 & 157 & 500 & 27,400 & 1220 & 0.0445 & & 0.0445 & 0.1007 & 659 & 2490 \\
\hline Straight & 679 & 1 & $78-79$ & 8.624 & 0.5 & & & & 52.8 & 304 & 1000 & 157 & 500 & 27,400 & 1888 & 0.0689 & & 0.0689 & 0.1007 & 176 & 3832 \\
\hline Weld & & D-1 & 79 & & & & & & & & & & & & 2867 & 0.1046 & 1.0 & 0.1046 & & 264 & 5753 \\
\hline Elbow & 680 & 2 & $79-80$ & 8.624 & 0.5 & 15 & 1.9 & $60^{\circ}$ & & 304 & 1000 & 157 & 500 & 27,400 & 2961 & 0.1081 & & 0.1081 & 0.1007 & 963 & 7310 \\
\hline Weld & & $D-1$ & 80 & & & & & & & & & & & & 2759 & 0.1007 & 1.0 & 0.1007 & & 667 & 7310 \\
\hline Straight & 681 & 1 & $80-81$ & 8.624 & 0.5 & & & & 10.8 & 304 & 1000 & 157 & 500 & 27,400 & 2060 & 0.0752 & & 0.0752 & 0.1007 & 1452 & 4949 \\
\hline Condenser Attachment & & $\mathrm{D}-1$ & 81 & & & & & & & & & & & & :1863 & 0.0680 & 1.0 & & & 1452 & 4949 \\
\hline Run of Tee 76 & 687 & 1 & $76-87$ & 8.624 & 0.5 & & & & 68.4 & 304 & 1000 & 157 & 500 & 27,400 & 1896 & 0.0692 & & 0.1231 & 0.1007 & 771 & 2674 \\
\hline Bend & 688 & 3 & $87-88$ & 8.624 & 0.5 & 48 & 6.0 & $90^{\circ}$ & & 304. & 1000 & 157 & 500 & 27,400 & 1896 & 0.0692 & & 0.0692 & 0.1007 & 292 & 2541 \\
\hline Straight & 689 & 1 & $88-89$ & 8.624 & 0.5 & & & & 52.8 & 304 & 1000 & 157 & 500 & 27,400 & 2001 & 0.0730 & & 0.0730 & 0.1007 & 617 & 2847 \\
\hline Weld & & $\mathrm{D}-1$ & 89 & & & & & & & & & & & & |3041 & 0.1110 & 1.0 & 0.1110 & & 251 & 4304 \\
\hline Elbow & 690 & 2 & $89-90$ & 8.624 & 0.5 & 15 & 1.9 & $60^{\circ}$. & & 304 & 1000 & 157 & 500 & 27,400 & 3115 & 0.1137 & & 0.1137 & 0.1007 & 378 & 4743 \\
\hline Weld & & D-1 & 90 & & & & & & & & & & & & 2900 & 0.1058 & 1.0 & 0.1058 & & 1097 & 4743 \\
\hline Straight & 691 & 1 & $90-91$ & 8.624 & 0.5 & & & & 10.8 & 304 & 1000 & 157 & 500 & 27,400 & 2396 & 0.0874 & & 0.0874 & 0.1007 & 761 & 4038 \\
\hline Condenser Attachment & & $D-1$ & 91 & & & & & & & & & & & & ;2391 & 0.0873 & 1.0 & 0.0873 & & 1505 & 4038 \\
\hline
\end{tabular}




\begin{tabular}{|c|c|c|c|c|c|c|c|c|c|c|c|c|c|c|c|c|c|c|c|c|c|}
\hline $\begin{array}{l}\text { Model Number } 6 \\
\text { Recirculation Loop No. } 2 \\
\text { (Main Line) } \\
\text { Component } \\
\text { or Discontinuity }\end{array}$ & 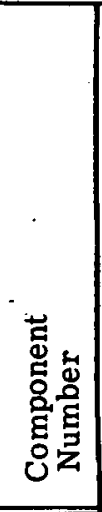 & 产 & 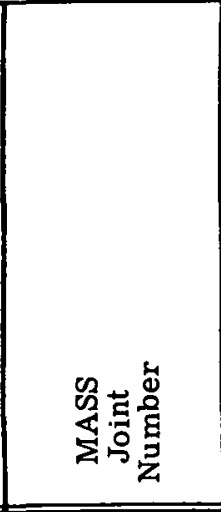 & 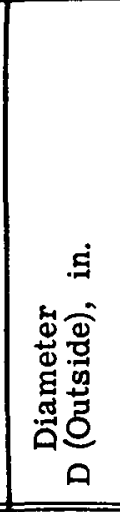 & 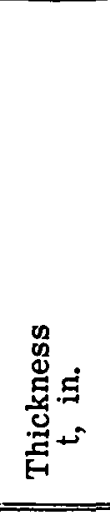 & 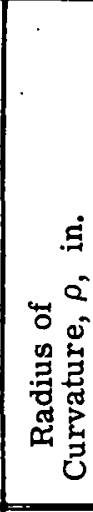 & $\stackrel{*}{Q}$ & 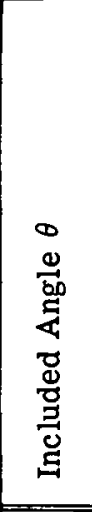 & 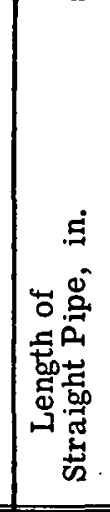 & 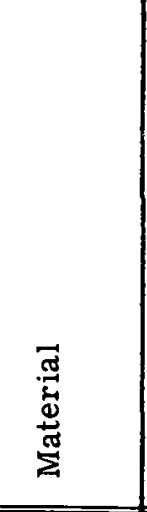 & 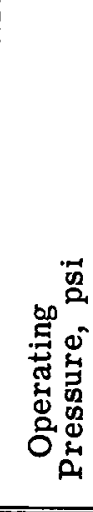 & 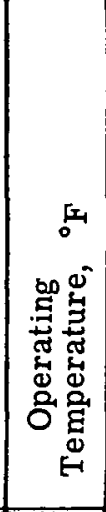 & 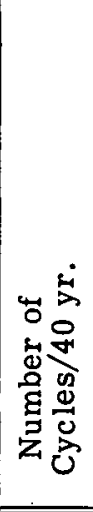 & 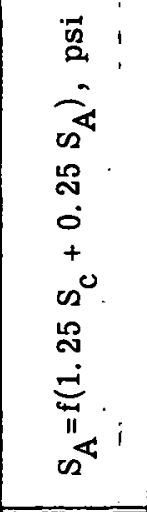 & 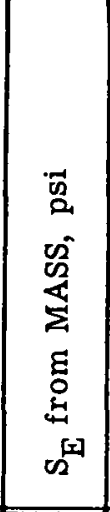 & 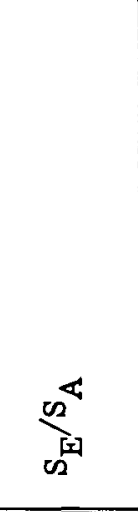 & 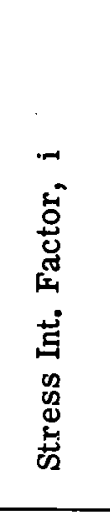 & 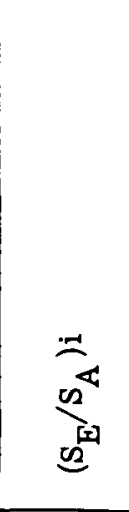 & $\underset{4}{\stackrel{d}{4}}$ & 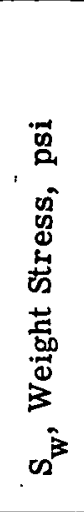 & 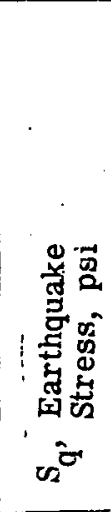 \\
\hline Pres. Vessel Nozzle Weld & & $D-1$ & 102 & & & & & & & & & & & & 659 & 0.0252 & 1.0 & 0.0252 & & $\overline{95}$ & $\overline{858}$ \\
\hline Elbow & 1001 & 2 & $102-103$ & 25.99 & 0.982 & 39.0 & 1.5 & $90^{\circ}$ & & 316 & 1015 & 555 & 360 & 26,100 & 1625 & 0.0623 & & 0.0623 & 1.0 & 95 & 676 \\
\hline Weld & & D-1 & 103 & & & & & & & & & & & & 1625 & 0.0623 & 1.0 & 0.0623 & & 33 & 819 \\
\hline Straight & 1002 & 1 & $103-137$ & 25,99 & 0.982 & & & & 19.5 & 316 & 1015 & 555 & 360 & 26,100 & 708 & 0.0271 & & 0.0271 & 1.0 & 28 & 475 \\
\hline Straight & 1002 & 1 & $137-138$ & 25.99 & 0.982 & & & & 19.5 & 316 & 1015 & 555 & 360 & 26,100 & 702 & 0.0269 & & 0.0289 & 1.0 & 31 & 418 \\
\hline Hanger & & D-2 & 138 & & & & & & & & & & & & 697 & 0.0267 & 1.0 & 0.0267 & & 36 & 381 \\
\hline Run of Tee 135 & 1003 & 1 & $138-135$ & 25.99 & 0.982 & & & & 213.0 & 316 & 1015 & 555 & 360 & 26,100 & 697 & 0.0267 & & 0.0490 & 1.0 & 36 & 792 \\
\hline Run of Tee 135 & 1004 & 1 & $135-104$ & 25.99 & 0.982 & & & & 103.0 & 316 & 1015 & 555 & 360 & 26,100 & 616 & 0.0236 & & 0.0490 & 1.0 & 86 & 790 \\
\hline End of Valve - Weld & & $D-1$ & 104 & & & & & & & & & & & & 592 & 0.0227 & 1.0 & 0.0227 & & 48 & 720 \\
\hline Valve & 1005 & 4 & $104-105$ & 25.99 & 6.5 & & & & 60.0 & 316 & 1015 & 555 & 360 & 26,100 & 170 & 0.0065 & & 0.0065 & 0.2923 & 14 & 207 \\
\hline End of Valve - Weld & & $D-1$ & 105 & & & & & & & & & & & & 1332 & 0.0510 & 1.0 & 0.0510 & & 9 & 131 \\
\hline Elbow & 1006 & 2 & $105-106$ & 25.99 & 0.982 & 39.0 & 1.5 & $90^{\circ}$ & & 316 & 1015 & 555 & 360 & 26,100 & 1332 & 0.0510 & & 0.0510 & 1.0 & 48 & 511 \\
\hline weld & & $D-1$ & 106 & & & & & & & & & & & & 316 & 0.0131 & 1.0 & 0.0121 & & 173 & 723 \\
\hline Straight & 1007 & 1 & $106-107$ & 25.99 & 0.982 & & & & 18.6 & 316 & 1015 & 555 & 360 & 26,100 & 193 & 0.0074 & & 0.0074 & 1.0 & 76 & 436 \\
\hline Thermocouple & & D-3 & Bet. $106 \& 107$ & & & & & & & & & & & & & & & & & & \\
\hline $\begin{array}{l}\text { Blanked-Off } \\
\text { Decontamination Nozzle }\end{array}$ & & D-5 & Bet. 106\&107 & & & & & & & & & & & & & & & & & & \\
\hline 1 in. Pres. Sensing Line & & $\left|\begin{array}{l}D-3 \\
D-1\end{array}\right|$ & $\begin{array}{l}\text { Bet. 106\&107 } \\
107\end{array}$ & & & & & & & & & & & & 295 & 0.0113 & 10 & 0.0113 & & 45 & 546 \\
\hline $\begin{array}{l}\text { Weld } \\
\text { Elbow }\end{array}$ & 1008 & $\begin{array}{c}D-1 \\
2\end{array}$ & $107-108$ & 25.99 & 0.982 & 26.0 & 1.0 & $90^{\circ}$ & & 316 & 1015 & 555 & 360 & 26,100 & 1216 & 0.0466 & & 0.0466 & 1.0 & 132 & 1229 \\
\hline $\begin{array}{l}\text { Pump Connection } \\
\text { Pump }\end{array}$ & 1009 & $\begin{array}{c}D-1 \\
5\end{array}$ & $\begin{array}{l}108 \\
108-110\end{array}$ & & & & & & & & & & & & 1216 & 0.0466 & 1.0 & 0.0466 & & 182 & 1243 \\
\hline Pump Connection & & $\mathrm{D}-1$ & 110 & & & & & & & & & & & & 1176 & 0.0451 & 1.0 & 0.0451 & & 102 & 720 \\
\hline Sector of Elbow & 1010 & 2 & $110-117$ & 25.99 & 0.982 & 40.1 & 1.5 & $48^{\circ}$ & & 316 & 1015 & 555 & 360 & 26,100 & 2063 & 0.0790 & & 0.0790 & 1.0 & 102 & 627 \\
\hline $\begin{array}{l}\text { Thermocouple } \\
1 \text { in. Pres Sensing Line }\end{array}$ & & $\left|\begin{array}{l}D-3 \\
D-3\end{array}\right|$ & $\begin{array}{l}\text { Bet. 110\&117 } \\
\text { Bet.110\&117 }\end{array}$ & & & & & & & & & & & & & & & & & & \\
\hline Bypass Line Connection & & $D-4$ & 117 & & & & & & & & & & & & 2063 & 0.0790 & 1.875 & 0.1480 & & 201 & 735 \\
\hline Sector of Elbow & 1011 & 2 & $117-111$ & 25.99 & 0.982 & 42.5 & 1.6 & 25.7 & & 316 & 1015 & 555 & 360 & 26,100 & 1562 & 0.0598 & & 0.0598 & 1.0 & 200 & 739 \\
\hline
\end{tabular}




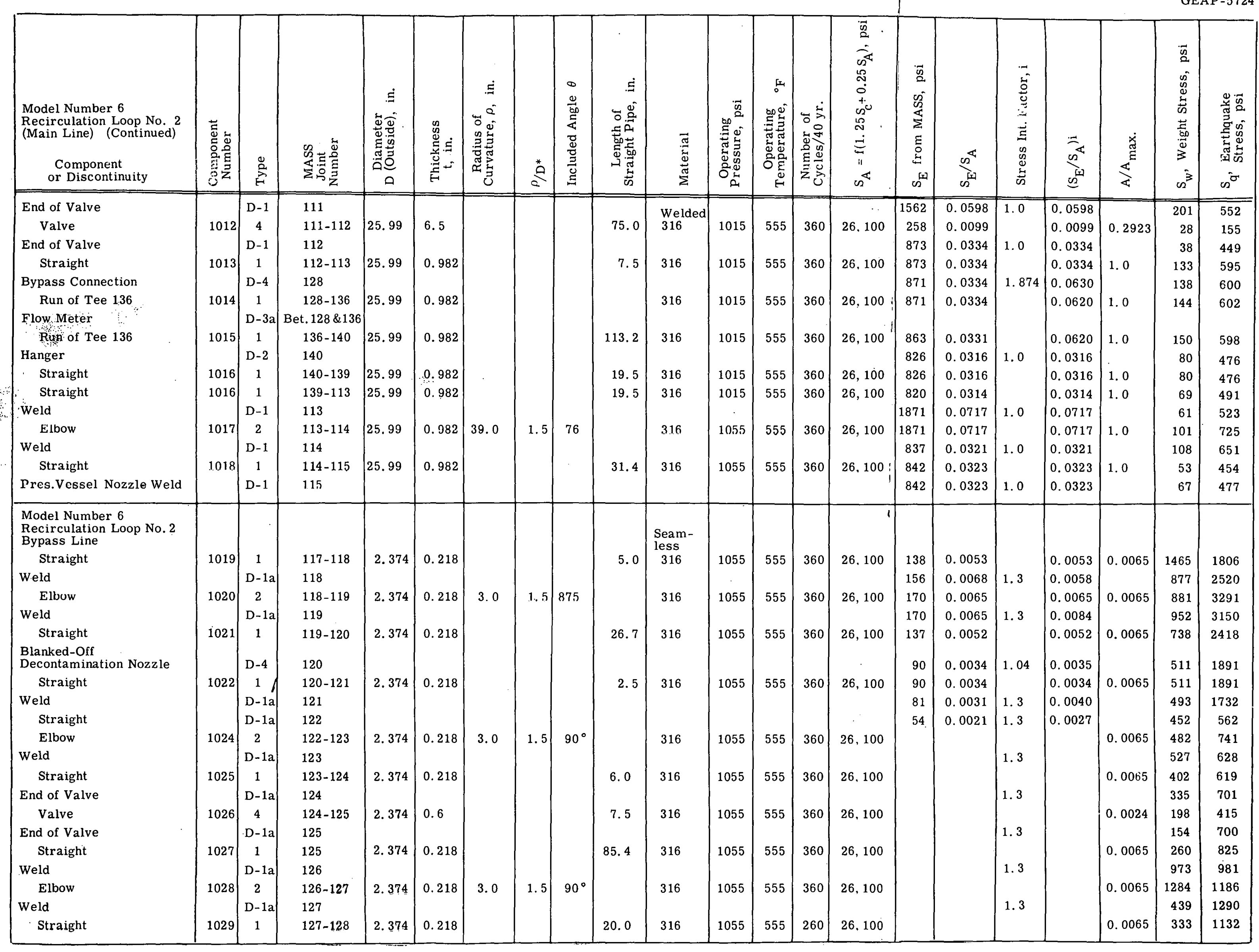




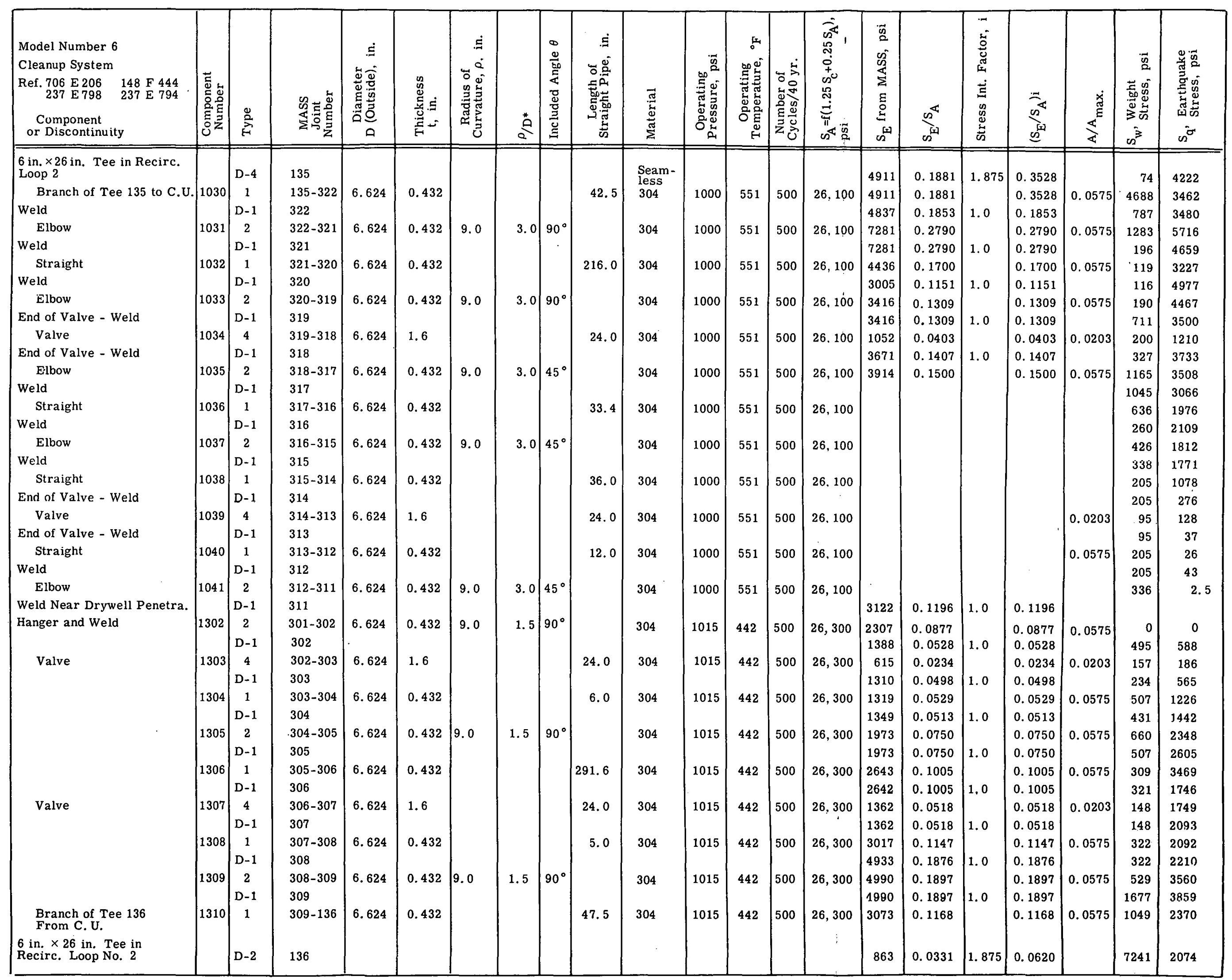




\begin{tabular}{|c|c|c|c|c|c|c|c|c|c|c|c|c|c|c|c|c|c|c|c|c|c|}
\hline $\begin{array}{l}\text { Model Number } 7 \\
\text { Recirculation Loop No. } 3 \\
\text { (Main Line) } \\
\vdots \text { Component } \\
\text { or Discontinuity }\end{array}$ & 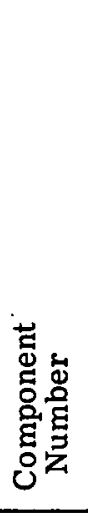 & 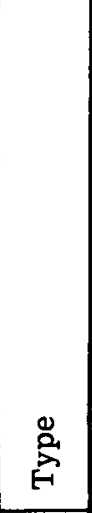 & 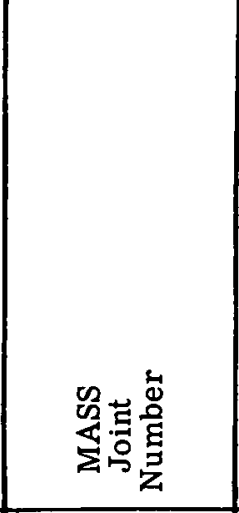 & 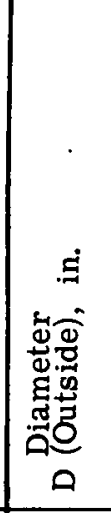 & 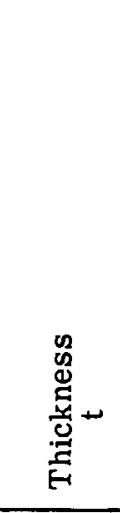 & 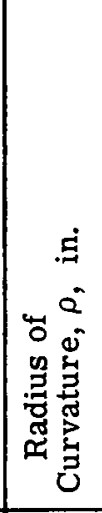 & $\stackrel{*}{Q}$ & 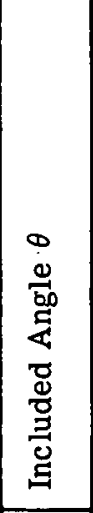 & 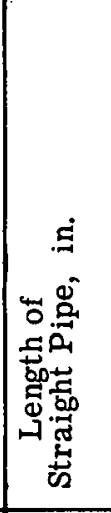 & 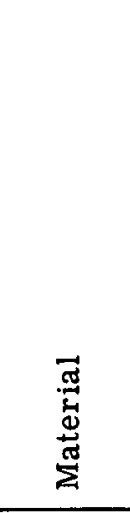 & 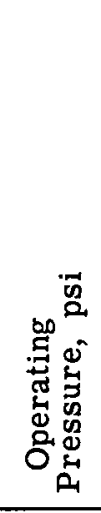 & 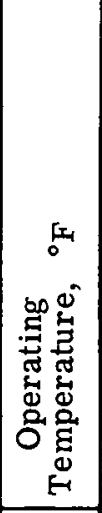 & 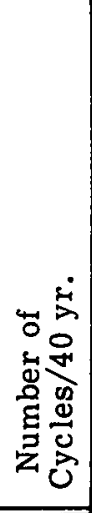 & 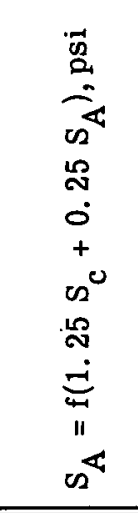 & 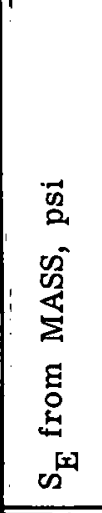 & 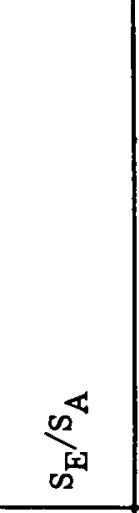 & 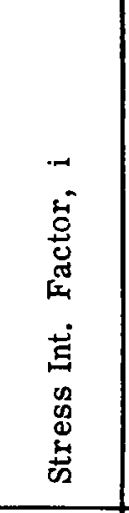 & 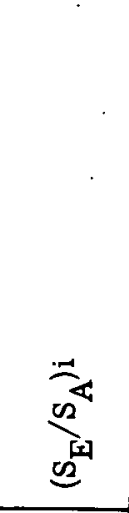 & 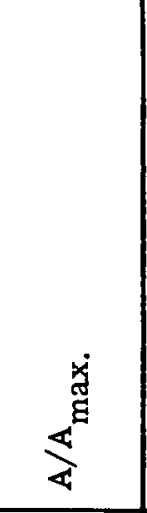 & 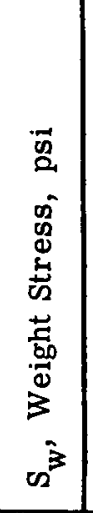 & 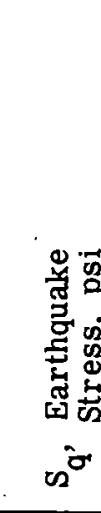 \\
\hline Pres. Vessel Nozzle Weld & & $\mathrm{D}-1$ & 202 & & & & & & & & & & & & 689 & 0.0264 & 1.0 & 0.0264 & & 145 & 846 \\
\hline Elbow & 701 & 2 & $202-203$ & 25.99 & 0.982 & 39.0 & 1.5 & 90 & & $\begin{array}{l}\text { Welded } \\
316\end{array}$ & 1015 & 555 & 360 & 26,100 & 1621 & 0.0621 & & 0.0621 & 1.0 & 56 & 617 \\
\hline weld & & $D-1$ & 203 & & & & & & & & & & & & 1621 & 0.0621 & 1.0 & 0.0621 & & 25 & 828 \\
\hline Straight & 702 & 1 & $203-237$ & 25.99 & 0.982 & & & & 19.5 & 316 & 1015 & 555 & 360 & 26,100 & 706 & 0.0270 & & 0.0270 & 1.0 & 23 & 363 \\
\hline Straight & 702 & & $237-238$ & 25.99 & 0.982 & & & & 19.5 & 316 & 1015 & 555 & 360 & 26,100 & 699 & 0.0268 & 1.0 & 0.0268 & & 22 & 367 \\
\hline Straight & 702 & & $238-235$ & 25.99 & 0.982 & & & & 213.0 & 316 & 1015 & 555 & 360 & 26,100 & 692 & 0.0265 & & 0.0265 & 1.0 & 15 & 361 \\
\hline Hanger & & $D-2$ & 235 & & & & & & & & & & & & 628 & 0.0241 & 1.0 & 0.0241 & & 15 & 452 \\
\hline Straight & 703 & 1 & $235-204$ & 25.99 & 0.982 & & & & 103.0 & 316 & 1015 & 555 & 360 & 26,100 & 628 & 0.0241 & & 0.0241 & 1.0 & 19 & 452 \\
\hline Valve Attachment & & $D-1$ & 204 & & & & & & & & & & & & 605 & 0.0232 & 1.0 & 0.0232 & & 5 & 548 \\
\hline Valve & 704 & 4 & 204-205 & 25.99 & 6.5 & & & & 60.0 & 316 & 1015 & 555 & 360 & 26,100 & 174 & 0.0067 & & 0.0067 & 0.2923 & 6 & 158 \\
\hline Valve Attachment & & $D-1$ & 205 & & & & & & & & & & & & 1364 & 0.0523 & 1.0 & 0.0523 & & 50 & 100 \\
\hline Elbow & 705 & 2 & 205-206 & 25.99 & 0.982 & 39 & 1.5 & $90^{\circ}$ & & 316 & 1015 & 555 & 360 & 26,100 & 1364 & 0.0523 & & 0.0523 & 1.0 & 165 & 419 \\
\hline Weld & & $D-1$ & 206 & & & & & & & & & & & & 339 & 0.0130 & 1.0 . & 0.0130 & & 72 & 653 \\
\hline Straight & 706 & 1 & 206-207 & 25.99 & 0.982 & & & & 18.6 & 316 & 1015 & 555 & 360 & 26,100 & 192 & 0.0074 & & 0.0074 & 1.0 & 53 & 353 \\
\hline Thermocouple & & D-3 & Bet. 206\&207 & & & & & & & & & & & & & & & & & & \\
\hline 1 in. Pres. Sensing Line & & $D-3$ & Bet. 206\& 207 & & & & & & & & & & & & & & & & & & \\
\hline $\begin{array}{l}\text { 'Blanked-Off Decontamina- } \\
\text { tion Nozzle }\end{array}$ & & $D-5$ & Bet. 206\& 207 & & & & & & & & & & & & & & & & & & \\
\hline weld & & $D-1$ & 207 & & & & & & & & & & & & 263 & 0.0101 & 1.0 & 0.0101 & & 161 & 473 \\
\hline . Elbow & 707 & 2 & $207-208$ & 25.99 & 0.982 & 25 & 1.0 & $90^{\circ}$ & & 316 & 1015 & 555 & 360 & 26,100 & 1192 & 0.0457 & & 0.0457 & 1.0 & 111 & 1057 \\
\hline Pump Attachment & & $D-1$ & 208 & & & & & & & & & & & & 1198 & 0.0458 & 1.0 & 0.0458 & & 111 & 935 \\
\hline Pump & 708 & 5 & $208-210$ & & & & & & & & & & & & & & & & & & \\
\hline Pump Attachment & & $D-1$ & 210 & & & & & & & & & & & & 1195 & 0.0458 & 1.0 & 0.0458 & & 32 & 766 \\
\hline Sector of Elbow & 709 & 2 & $210-217$ & & & 40.1 & 1.6 & 47.9 & & 316 & 1015 & 555 & 360 & 26,100 & 2091 & 0.0801 & & 0.0801 & 1.0 & 63 & 583 \\
\hline Thermocouple & & $D-3$ & Bet. 210\&217 & & & & & & & & & & & & & & & & & & \\
\hline 1 in. Pres. Sensing Line & & $\begin{array}{l}D-3 \\
D-4\end{array} \mid$ & \begin{tabular}{|c|} 
Bet. 210\& 217 \\
217
\end{tabular} & & & & & & & & & & & & 2091 & 00801 & 1.875 & 1502] & & 65 & 587 \\
\hline $\begin{array}{l}\text { Bypass Connection } \\
\text { Sector of Elbow }\end{array}$ & 710 & $\begin{array}{c}D-4 \\
2\end{array} \mid$ & $\begin{array}{l}217 \\
217-211\end{array}$ & 25.99 & 0.982 & 42.4 & 1.6 & 25.7 & & 316 & 1015 & 555 & 360 & 26,100 & 1579 & 0.0605 & & 0.0605 & 1.0 & 34 & 527 \\
\hline
\end{tabular}




\begin{tabular}{|c|c|c|c|c|c|c|c|c|c|c|c|c|c|c|c|c|c|c|c|c|c|}
\hline $\begin{array}{l}\text { Model Number } 7 \\
\text { Recirculation Loop No. } 3 \\
\text { (Main Line) (Continued) } \\
\text { Component } \\
\text { or Discontinuity }\end{array}$ & 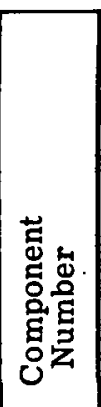 & 总 & 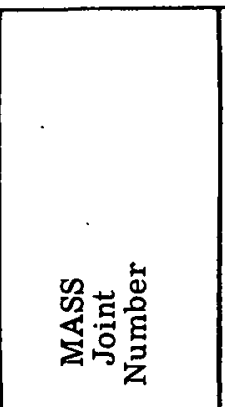 & 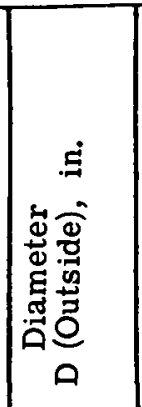 & 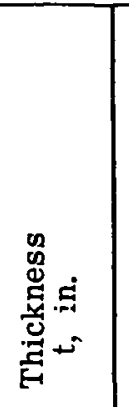 & 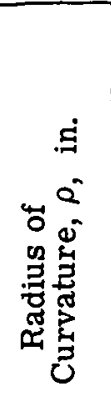 & $\stackrel{*}{a}$ & 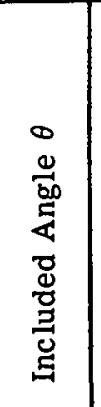 & 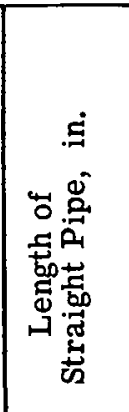 & 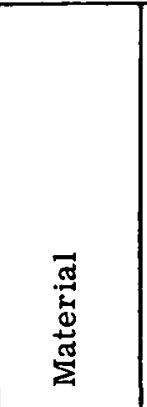 & 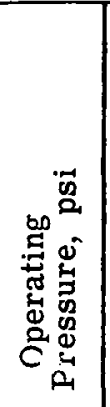 & 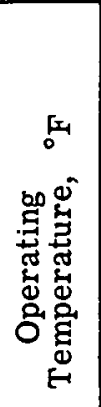 & 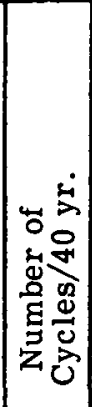 & 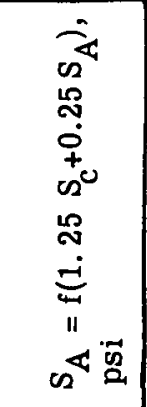 & 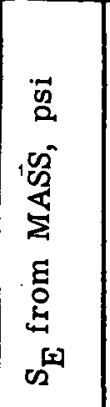 & $\underset{2}{\underbrace{4}}$ & 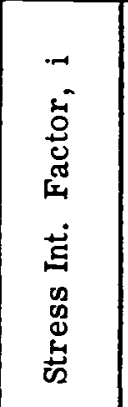 & $\begin{array}{l}\overrightarrow{\sigma^{4}} \\
\text { ज्ञ } \\
0^{2}\end{array}$ & 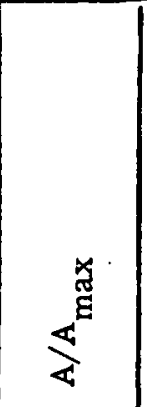 & 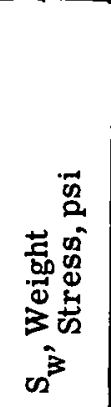 & 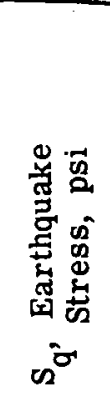 \\
\hline $\begin{array}{l}\text { Valve Attachment } \\
\text { Valve } \\
\text { Valve Attachment } \\
\text { Straight } \\
\text { Bypass Connection } \\
\text { Straight } \\
\text { Flow Meter } \\
\text { Hanger } \\
\text { Straight } \\
\text { Straight } \\
\text { Straight } \\
\text { Weld } \\
\text { Elbow } \\
\text { Weld } \\
\text { Straight } \\
\text { Pres. Vessel Nozzle Weld }\end{array}$ & $\begin{array}{l}714 \\
714 \\
714\end{array}$ & \begin{tabular}{c|c}
$D-1$ & \\
4 & \\
$D-1$ & 1 \\
1 & $D-4$ \\
1 & $D-3 a$ \\
$D-2$ & \\
1 \\
1 \\
1 \\
$D-1$ \\
2 \\
$D-1$ \\
1 \\
$D-1$ \\
\end{tabular} & \begin{tabular}{|c|}
211 \\
$211-212$ \\
212 \\
$212-228$ \\
228 \\
$228-236$ \\
Bet. $228 \& 236$ \\
236 \\
$236-240$ \\
$240-239$ \\
$239-213$ \\
213 \\
$213-214$ \\
214 \\
$214-215$ \\
215 \\
\end{tabular} & $\begin{array}{l}25.99 \\
25.99 \\
25.99\end{array}$ & $\begin{array}{l}0.982 \\
0.982 \\
0.982\end{array} \mid$ & 38.9 & 1.5 & $76^{\circ}$ & \begin{tabular}{|r}
113.2 \\
19.2 \\
19.2
\end{tabular} & $\begin{array}{l}316 \\
316 \\
316 \\
316\end{array}$ & $\begin{array}{l}1015 \\
1015 \\
1015\end{array}$ & $\begin{array}{l}555 \\
555 \\
555\end{array}$ & $\begin{array}{l}360 \\
360 \\
360\end{array}$ & $\begin{array}{l}26,100 \\
26,100 \\
26,100 \\
26,100 \\
26,100 \\
26,100\end{array}$ & $\begin{array}{r}1579 \\
261 \\
880 \\
880 \\
878 \\
878 \\
\\
860 \\
859 \\
823 \\
817 \\
1864 \\
1864 \\
825 \\
816 \\
816 \\
\end{array}$ & $\begin{array}{l}0.0605 \\
0.0100 \\
0.0337 \\
0.0337 \\
0.0336 \\
0.0336 \\
\\
0.0330 \\
0.0330 \\
0.0315 \\
0.0313 \\
0.0714 \\
0.0714 \\
0.0316 \\
0.0313 \\
0.0313 \\
\end{array}$ & $\begin{array}{l}1.0 \\
1.0 \\
1.875 \\
1.0\end{array}$ & $\begin{array}{l}0.0605 \\
0.0100 \\
0.0337 \\
0.0337 \\
0.0630 \\
0.0336 \\
\\
0.0330 \\
0.0330 \\
0.0315 \\
0.0313 \\
0.0714 \\
0.0714 \\
0.0316 \\
0.0313 \\
0.0313 \\
\end{array}$ & $\begin{array}{l}1.0 \\
\\
1.0 \\
1.0 \\
1.0 \\
1.0 \\
1.0\end{array}$ & $\begin{array}{r}4 \\
4 \\
13 \\
12 \\
19 \\
15 \\
15 \\
8 \\
8 \\
7 \\
6 \\
7 \\
16 \\
7 \\
101 \\
\end{array}$ & $\begin{array}{l}422 \\
146 \\
508 \\
505 \\
506 \\
462 \\
462 \\
462 \\
424 \\
435 \\
465 \\
622 \\
593 \\
597 \\
399 \\
413 \\
\end{array}$ \\
\hline $\begin{array}{l}\text { Model } 7 \text { - Recirc Loop } \\
\text { No. } 3 \text { - Bypass Line } \\
\text { Straight } \\
\text { Weld } \\
\text { Elbow } \\
\text { Weld } \\
\text { Straight } \\
\text { Blanked-Off Decontamina- } \\
\text { tion Nozzle } \\
\text { Straight } \\
\text { Weld } \\
\text { Straight } \\
\text { Weld } \\
\text { Elbow } \\
\text { Weld } \\
\text { Straight } \\
\text { Valve Attachment } \\
\text { Valve } \\
\text { Valve Attachment } \\
\text { Straight } \\
\text { Weld } \\
\text { Elbow } \\
\text { Weld } \\
\text { Straight }\end{array}$ & $\begin{array}{l}722 \\
723 \\
724 \\
725 \\
726\end{array}$ & \begin{tabular}{c|}
1 \\
$D-1 a$ \\
2 \\
$D-1 a$ \\
1 \\
$D-4$ \\
1 \\
$D-1 a$ \\
1 \\
$D-1 a$ \\
2 \\
$D-1 a$ \\
1 \\
$D-1 a$ \\
4 \\
$D-1 a$ \\
1 \\
$D-1 a$ \\
2 \\
$D-1 a$ \\
1
\end{tabular} & $\begin{array}{l}217-218 \\
218 \\
218-219 \\
219 \\
219-220 \\
220 \\
220-221 \\
221 \\
221-222 \\
222 \\
222-223 \\
223 \\
223-224 \\
224 \\
224-225 \\
225 \\
225-226 \\
226 \\
226-227 \\
227 \\
227-228\end{array}$ & $\begin{array}{l}2.374 \\
2.374 \\
2.374 \\
2.374\end{array}$ & $\begin{array}{l}0.218 \\
0.218 \\
0.60 \\
0.218\end{array}$ & 3.0 & 1.5 & $90^{\circ}$ & $\begin{array}{r}6.0 \\
7.5 \\
85.3\end{array}$ & $\begin{array}{l}\text { Seam- } \\
\text { less } \\
316 \\
\\
316 \\
\\
316\end{array}$ & 1055 & 555 & 360 & $\begin{array}{l}26,100 \\
26,100 \\
26,100 \\
26,100\end{array}$ & $\begin{array}{r}138 \\
159 \\
171 \\
171 \\
139 \\
\vdots \\
90 \\
90 \\
80 \\
80 \\
77 \\
89 \\
89 \\
68 \\
62 \\
37 \\
56 \\
79 \\
103 \\
103 \\
80 \\
113\end{array}$ & $\begin{array}{l}0.0053 \\
0.0061 \\
0.0066 \\
0.0066 \\
0.0053 \\
0.0034 \\
0.0034 \\
0.0031 \\
0.0031 \\
0.0030 \\
0.0034 \\
0.0034 \\
0.0026 \\
0.0024 \\
0.0014 \\
0.0021 \\
0.0030 \\
0.0039 \\
0.0039 \\
0.0031 \\
0.0043\end{array}$ & $\begin{array}{l}1.3 \\
1.3 \\
1.04 \\
1.3 \\
1.3 \\
1.3 \\
1.3 \\
1.3 \\
1.3 \\
1.3\end{array}$ & $\begin{array}{l}0.0053 \\
0.0079 \\
0.0066 \\
0.0086 \\
0.0053 \\
0.0035 \\
0.0034 \\
0.0040 \\
0.0031 \\
0.0039 \\
0.0034 \\
0.0044 \\
0.0026 \\
0.0031 \\
0.0014 \\
0.0027 \\
0.0030 \\
0.0051 \\
0.0039 \\
0.0040 \\
0.0043\end{array}$ & $\begin{array}{l}0.0065 \\
0.0065 \\
0.0065 \\
0.0065\end{array}$ & \begin{tabular}{r|}
1661 \\
1000 \\
1007 \\
1087 \\
837 \\
549 \\
549 \\
533 \\
533 \\
472 \\
488 \\
565 \\
431 \\
368 \\
218 \\
178 \\
301 \\
975 \\
1286 \\
437 \\
4532
\end{tabular} & \begin{tabular}{r|}
2047 \\
2340 \\
3073 \\
2784 \\
2127 \\
1966 \\
1966 \\
1788 \\
1788 \\
498 \\
654 \\
528 \\
525 \\
637 \\
377 \\
468 \\
792 \\
803 \\
979 \\
1095 \\
1390 \\
\end{tabular} \\
\hline
\end{tabular}




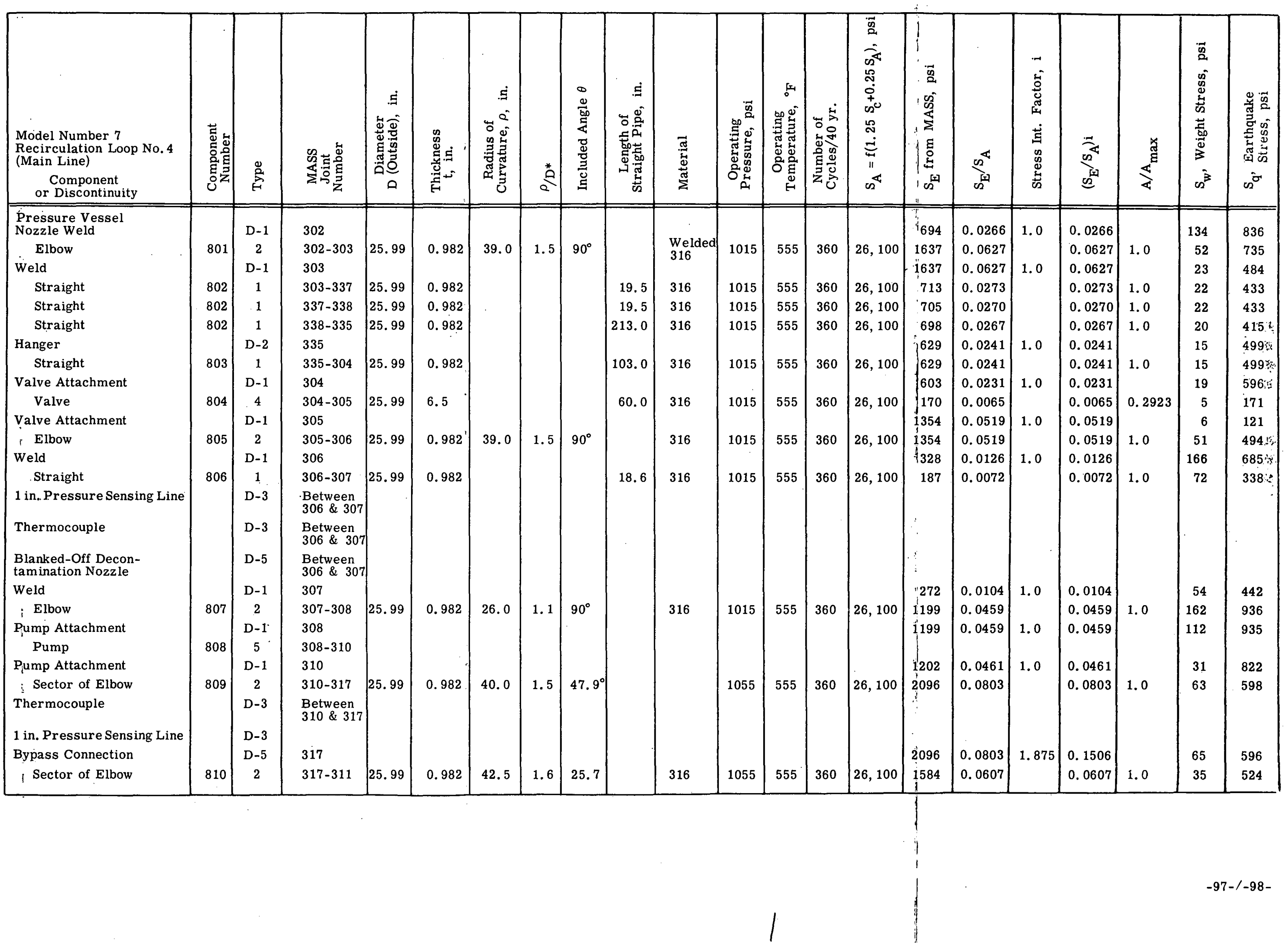




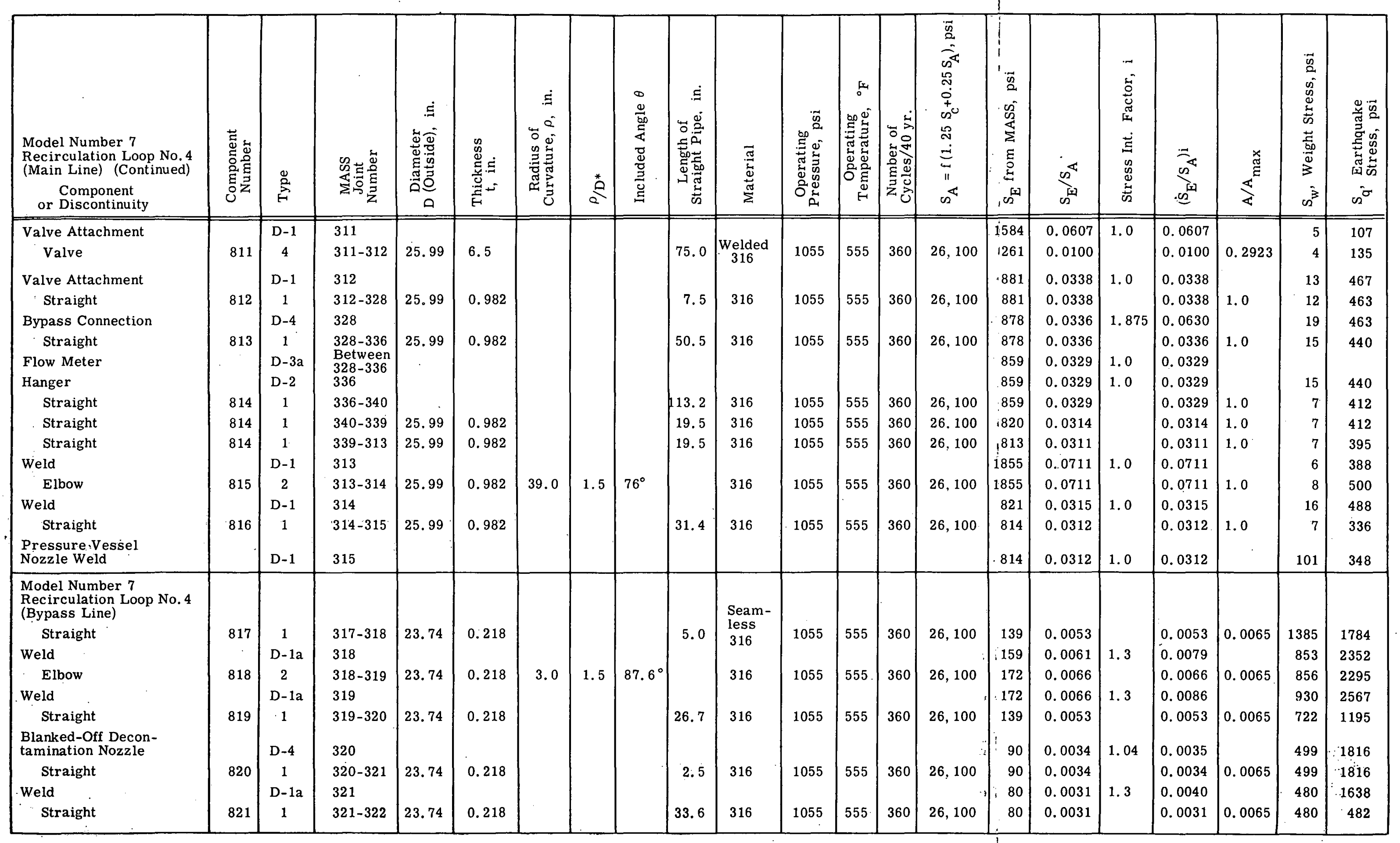




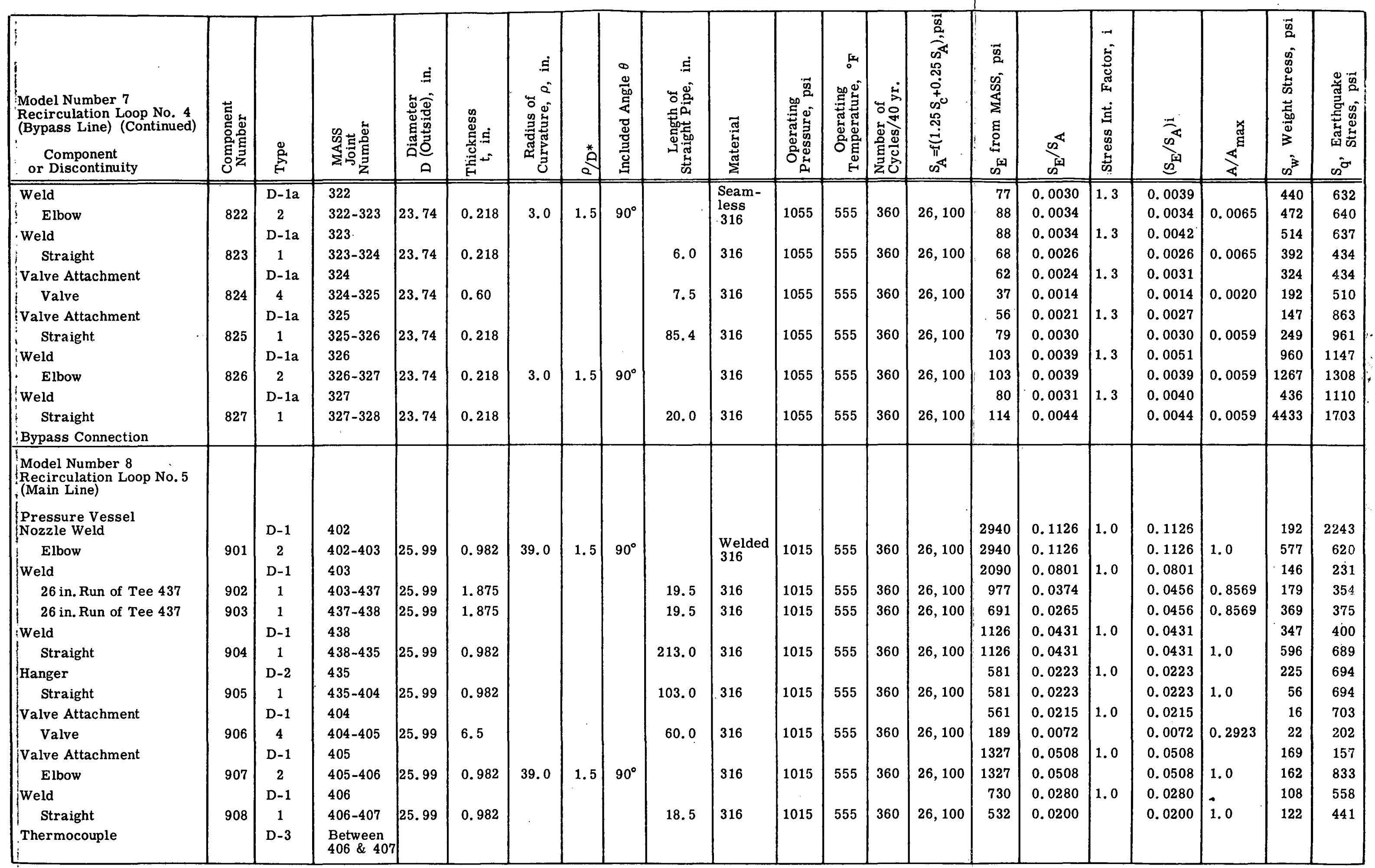




\begin{tabular}{|c|c|c|c|c|c|c|c|c|c|c|c|c|c|c|c|c|c|c|c|c|c|}
\hline $\begin{array}{l}\text { Model Number } 8 \\
\text { Recirculation Loop No. } 5 \\
\text { (Main Line) (Continued) } \\
\text { Component } \\
\text { or Discontinuity } \\
\end{array}$ & 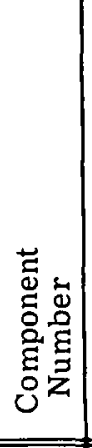 & $\sum_{\vec{H}}^{\stackrel{D}{*}}$ & 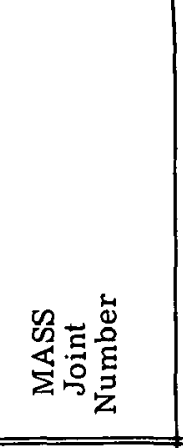 & 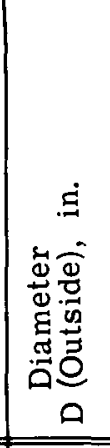 & 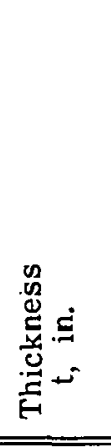 & 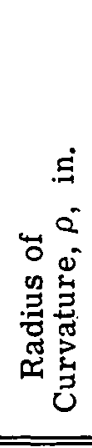 & $\stackrel{\text { a }}{a}$ & 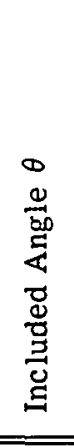 & 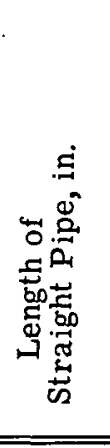 & 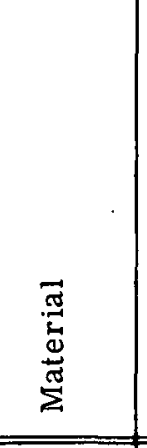 & 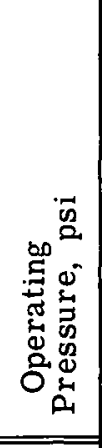 & 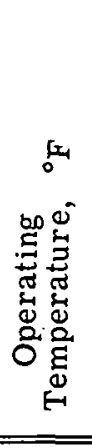 & 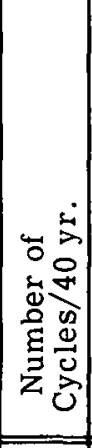 & 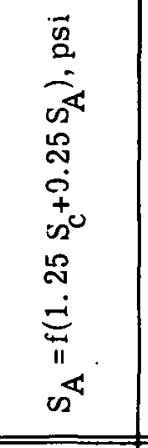 & 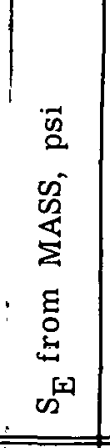 & $\underset{\omega^{4}}{\infty^{4}}$ & 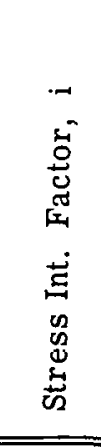 & 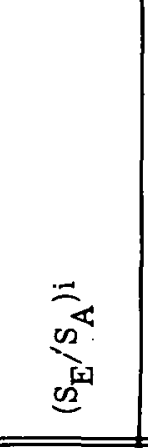 & 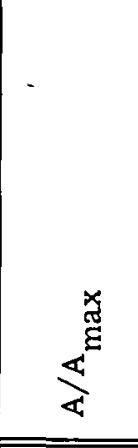 & 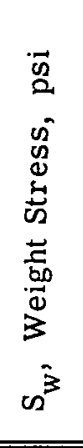 & 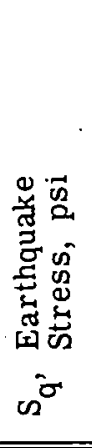 \\
\hline $\begin{array}{l}1 \text { in. Pressure Tap } \\
\text { Blanked-Off Decontam- } \\
\text { ination Nozzle }\end{array}$ & & $\begin{array}{l}\text { D-3 } \\
\text { D-5 }\end{array}$ & $\begin{array}{l}\text { Between } \\
406 \& 407 \\
\text { Between } \\
406 \& 407\end{array}$ & & & & & & & & & & & & & & & & & & \\
\hline Weld & & $D-1$ & & & & & & & & & & & & & 668 & 0.0256 & 1.0 & 0.0256 & & 262 & 1089 \\
\hline Elbow & 909 & 2 & $407-408$ & 25.99 & 0.982 & 26.0 & 1.0 & $90^{\circ}$ & & $\begin{array}{l}\text { Welded } \\
316\end{array}$ & 1015 & 555 & 360 & 26,100 & 1472 & 0.0564 & & 0.0564 & 1.0 & 200 & 1327 \\
\hline $\begin{array}{l}\text { Pump Attachment } \\
\text { Pump }\end{array}$ & 910 & $\begin{array}{c}\mathrm{D}-1 \\
5\end{array}$ & $\begin{array}{l}408 \\
408-410\end{array}$ & & & & & & & & & & & & 1472 & 0.0564 & 1.0 & 0.0564 & & 200 & 1327 \\
\hline Pump Attachment & & $\mathrm{D}-1$ & 410 & & & & & & & & & & & & 655 & 0.0251 & 1.0 & 0.0251 & $\cdot$ & .118 & 852 \\
\hline Sector of Elbow & 911 & 2 & $410-417$ & 25.99 & 0.982 & 40.0 & 1.5 & $48^{\circ}$ & & 316 & 1015 & 555 & 360 & 26,100 & 1296 & 0.0497 & & 0.0491 & 1.0 & 116 & 646 \\
\hline Thermocouple & & $D-3$ & $\begin{array}{l}\text { Between } \\
410 \& 417\end{array}$ & & & & & & & & & & & & & & & $\%$ & & & \\
\hline 1 in. Pressure Tap & & $\mathrm{D}-3$ & $\begin{array}{l}\text { Between } \\
410 \& 417\end{array}$ & & & & & & & & & & & & & & & & & & \\
\hline Bypass Connection & & D-4 & 417 & & & & & & & & & & & & 1296 & 0.0497 & 1.875 & 0.0932 & & 112 & 648 \\
\hline Sector of Elbow & 912 & 2 & $417-411$ & 25.99 & 0.982 & 42.5 & 1.6 & $26^{\circ}$ & & 316 & 1015 & 555 & 360 & 26,100 & 1064 & 0.0408 & & 0.0408 & 1.0 & 185 & 527 \\
\hline Valve Attachment & & D-1 & 411 & & & & & & & & & & & & 1064 & 0.0408 & 1.0 & 0.0408 & & 25 & 385 \\
\hline Valve & 913 & 4 & $411-412$ & 25.99 & 6.5 & & & & 75.0 & 316 & 1015 & 555 & 360 & 26,100 & 229 . & 0.0038 & & 0.0088 & 0.2923 & 31 & 144 \\
\hline Valve Attachment & & D-1 & 412 & & & & & & & & & & & & 798 & 0.0306 & 1.0 & 0.0306 & & 107 & 500 \\
\hline Straight & 914 & 1 & $412-428$ & 25.99 & 0.982 & & & & 7.5 & 316 & 1015 & 555 & 360 & 26,100 & 818 & 0.0314 & & 0.0314 & $1: 0$ & 116 & $4 \hat{99}$ \\
\hline Bypass Connection & & $D-4$ & 428 & & & & & & & & & & & & 819 & 0.0314 & 1.875 & 0.0589 & & 123 & 501 \\
\hline Straight & 915 & 1 & $428-436$ & 25.99 & 0.982 & & & & 50.5 & 316 & 1015 & 555 & 360 & 26,100 & 966 & 0.0370 & & 0.0370 & 1.0 & 200 & 483 \\
\hline Flow Meter & & D-3a & $\begin{array}{l}\text { Between } \\
428 \& .436\end{array}$ & & & & & & & & & & & & & & & & & & \\
\hline Hanger & & $\mathrm{D}-2$ & & & & & & & & & & & & & 966 & 0.0370 & 1.0 & 0.0370 & & 200 & 483 \\
\hline Straight & 916 & 1 & $436-440$ & 25.99 & 0.982 & & & & 113.2 & 316 & 1015 & 555 & 360 & 26,100 & 1328 & 0.0509 & & 0.0509 & 1.0 & 200 & 500 \\
\hline Weld & & D-1 & 440 & & & & & & & & & & & & 1328 & 0.0509 & 1.0 & 0.0509 & & 396 & 291 \\
\hline $26 \mathrm{in}$. Run of Tee & 917 & 1 & $440-439$ & 25.99 & 1.875 & & & & 19.5 & 316 & 1055 & 555 & 360 & 26,100 & 810 & 0.0310 & & 0.0378 & 0.8569 & 230 & 308 \\
\hline 26 in. Run of Tee & 918 & 1 & $439-413$ & 25.99 & 1.875 & & & & 19.5 & 316 & 1055 & 555 & 360 & 26,100 & 759 & 0.0291 & & 0.0355 & 0.8569 & 250 & 394 \\
\hline Weld & & D-1 & 413 & & & & & & & & & & & & 2983 & 0.1143 & 1.0 & 0.1143 & & 82 & 239 \\
\hline Elbow & 919 & 2 & $413-414$ & 25.99 & 0.982 & 39.0 & 1.5 & $76^{\circ}$ & & 316 & 1055 & 555 & 360 & 26,100 & 2983 & 0.1143 & & 0.1143 & 1.0 & 298 & 909 \\
\hline Weld & & $D-1$ & 414 & & & & & & & & & & & & 1639 & 0.0628 & 1.0 & 0.0628 & & 189 & 900 \\
\hline Straight & 920 & 1 & $414-415$ & 25.99 & 0.982 & & & & 31.4 & 316 & 1055 & 555 & 360 & 26,100 & 1523 & 0.0584 & & 0.0584 & 1.0 & 83 & 408 \\
\hline $\begin{array}{l}\text { Pressure Vessel } \\
\text { Nozzle Weld }\end{array}$ & & $\mathrm{D}-1$ & & & & & & & & & & & & & 1523 & 0.0584 & 1.0 & 0.0584 & & 117 & 863 \\
\hline
\end{tabular}




\begin{tabular}{|c|c|c|c|c|c|c|c|c|c|c|c|c|c|c|c|c|c|c|c|c|c|}
\hline $\begin{array}{l}\text { Model Number } 8 \\
\text { Redirculation Loop No. } 5 \\
\text { (Bypass Line) } \\
\quad \text { Component } \\
\text { or Discontinuity }\end{array}$ & 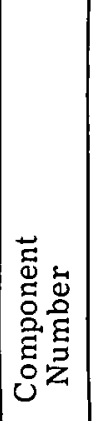 & 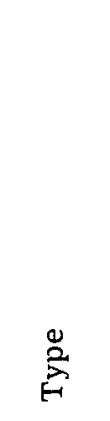 & 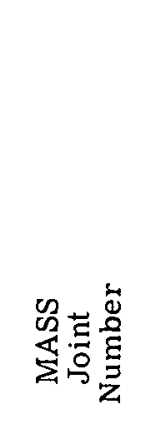 & 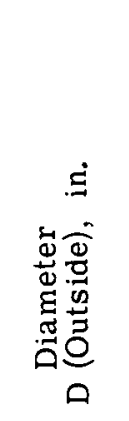 & 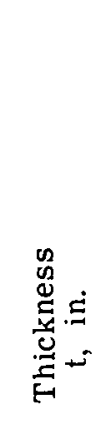 & 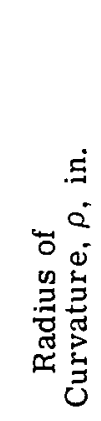 & $\stackrel{a}{a}$ & 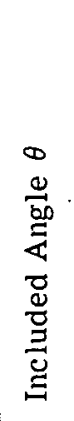 & 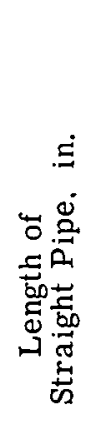 & 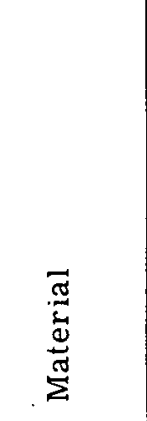 & 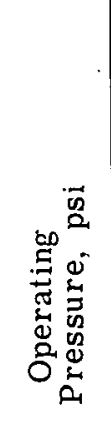 & 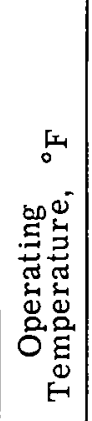 & 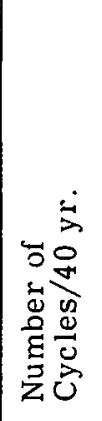 & 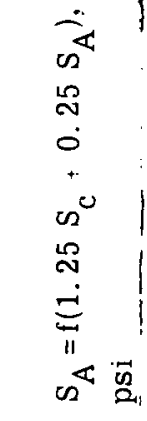 & 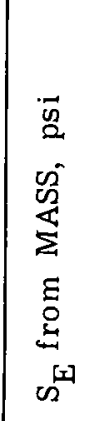 & $\underbrace{\sqrt[4]{4}}_{0^{4}}$ & 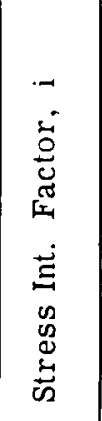 & $\begin{array}{l}\overrightarrow{7} \\
v^{4} \\
v^{4}\end{array}$ & 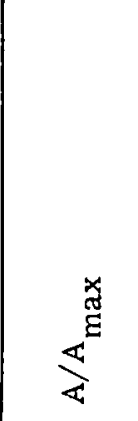 & 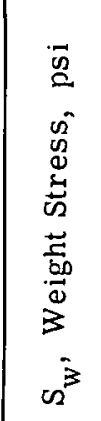 & 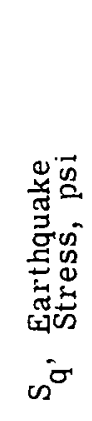 \\
\hline Straight & 921 & 1 & $417-418$ & 2.374 & 0.218 & & & & 5.0 & $\begin{array}{l}\text { Seamless } \\
316\end{array}$ & 1055 & 555 & 360 & 26,100 & 118 & 0.0045 & & 0.0045 & 0.0065 & 1469 & $\begin{array}{l}1923 \\
\end{array}$ \\
\hline Weld & & D-1a & & & & & & & & & & & & & 135 & 0.0052 & $\mid 1.3$ & 0.0068 & & 886 & 2337 \\
\hline Elbow & 922 & 2 & $418-419$ & 2. 374 & 0.218 & 3.0 & 1.5 & $88^{\circ}$ & & 316 & 1055 & 555 & 360 . & 26,100 & 151 & 0.0058 & & 0.0058 & 0.0065 & 890 & 3007 \\
\hline Weld & & D-1a & & & & & & & & & & & & & 151 & 0.0058 & 1.3 & 0.0075 & & 963 & 3166 \\
\hline Straight & 923 & 1 & $419-420$ & 2.374 & 0.218 & & & & 26.7 & 316 & 1055 & 555 & 360 & 26,100 & 120 & 0.0046 & & 0.0046 & 0.0065 & 747 & 2450 \\
\hline $\begin{array}{l}\text { Blanked-Off Decontam- } \\
\text { ination Nozzle }\end{array}$ & & D-4 & & & & & & & & & & & & & 76 & 0.0029 & 1.04 & 0.0030 & & 510 & 1620 \\
\hline Straight & 924 & 1 & $420-421$ & 2.374 & 0.218 & & & & 2.5 & 316 & 1055 & 555 & 360 & 26.100 & 76 & 0.0029 & & 0.0029 & 0.0065 & 510 & 1620 \\
\hline Weld & & D-1a & 421 & & & & & & & & & & & & 68 & 0.0026 & 1.3 & 0.0034 & & 491 & 1449 \\
\hline Straight & 925 & 1 & $421-422$ & 2.374 & 0.218 & & & & 33.6 & 316 & 1055 & 555 & 360 & 26,100 & 68 & 0.0026 & & 0.0026 & 0.0065 & 491 & 1449 \\
\hline Weld & & D-1a & 422 & & & & & & & & & & & & 67 & 0.0026 & 1.3 & 0.0034 & & 449 & .576 \\
\hline Elbow & 926 & 2 & $422-423$ & 2.374 & 0.218 & 3.0 & 1.5 & $90^{\circ}$ & & 316 & 1055 & 555 & 360 & 26.100 & 78 & 0.0030 & & 0.0030 & 0.0065 & 479 & 759 \\
\hline Weld & & D-1a & 423 & & & & & & & & & & & & 78 & 0.0030 & 1.3 & 0.0039 & & 522 & 733 \\
\hline Straight & 927 & 1 & $423-424$ & 2.374 & 0.218 & & & & 6.0 & 316 & 1055 & 555 & 360 & 26.100 & 60 & 0.0023 & & 0.0023 & 0.0065 & 398 & 727 \\
\hline Valve Connection & & D-1a. & 424 & & & & & & & & & & & & 54 & 0.0021 & 1.3 & 0.0027 & & 330 & 818 \\
\hline Valve & 928 & 4 & $424-425$ & 2.374 & $0.60^{\circ}$ & & & & 7.5 & 316 & 1055 & 555 & 360 & 26.100 & 32 & 0.0012 & & 0.0012 & 0.0024 & 195 & 484 \\
\hline Valve Comnection & & D-1a & 425 & & & & & & & & & & & & 47 & 0.0018 & 1.3 & 0.0023 & & 151 & 551 \\
\hline Straight & 929 & 1 & $425-426$ & 2.374 & 0.218 & & & & 85.3 & 316 & 1055 & 555 & 360 & 26.100 & 83 & 0.0032 & & 0.0032 & 0.0065 & 255 & 932 \\
\hline Weld & & D-1a & 426 & & & & & & & & & & & & 108 & 0.0041 & 1.3 & 0.0053 & & 975 & 1110 \\
\hline Elbow & 930 & 2 & $426-427$ & 2.374 & .0 .218 & 3.0 & 1.5 & $90^{\circ}$ & & 316 & 1055 & 555 & 360 & 26,100 & 108 & 0.0041 & & 0.0041 & 0.0065 & 1286 & 1329 \\
\hline Weld & & D-1a & 427 & & & & & & & & & & & & 84 & 0.0032 & 1.3 & 0.0042 & & 425 & 1479 \\
\hline Straight & 931 & 1 & $427-428$ & 2.374 & 0.218 & & & & 20.0 & 316 & 1055 & 555 & 360 & 26.100 & $99^{\circ}$ & 0.0038 & & 0.0038 & 0.0065 & 4498 & 1910 \\
\hline $\begin{array}{l}\text { Model Number } 8 \\
\text { from Shutdown Cooling }\end{array}$ & & & & & & & & & & & & & & & & & & & & & \\
\hline $\begin{array}{l}14 \text { in. } \times 24 \text { in. Tee in } \\
\text { Recirculation Loop No. } 5\end{array}$ & & D-4 & 439 & & & & & & & & & & & & 2937 & 0.1125 & 1.22 & 0.1373 & & 2692 & 4532 \\
\hline Straight & 932 & 1 & $439-511$ & 14.0 & 0.75 & & & & 32.7 & $\begin{array}{l}\text { Welded } \\
304\end{array}$ & 1000 & 146 & 360 & 26.100 & 2937 & 0.1125 & & 0.1373 & 0.2707 & 1383 & 4257 \\
\hline Weld & & D-1 & 511 & & & & & & & & & & & & 4351 & 0.1667 & 1.0 & 0.1667 & & 1611 & 4902 \\
\hline Elbow & 933 & 2 & $511-512$ & 14.0 & 0.75 & 21.0 & 1.5 & $90^{\circ}$ & & 304 & 1000 & 146 & 360 & 26,100 & 4351 & 0.1667 & & 0.1667 & 0.2707 & 644 & 4292 \\
\hline Weld & & D-1 & & & & & & & & & & & & & 2127 & 0.0815 & 1.0 & 0.0815 & & 563 & 4299 \\
\hline Straight & 934 & 1 & $512-513$ & 14.0 & 0.75 & & & & 6.0 & 304 & 1000 & 146 & 360 & 26,100 & 2075 & 0.0745 & & 0.0795 & 0.2707 & 527 & 4299 \\
\hline Weld & & D-1 & 513 & & & & & & & & & & & & 2080 & 0.0797 & 1.0 & 0.0797 & & 537 & 7460 \\
\hline
\end{tabular}




\begin{tabular}{|c|c|c|c|c|c|c|c|c|c|c|c|c|c|c|c|c|c|c|c|c|c|}
\hline $\begin{array}{l}\text { Model Number } 8 \\
\text { from Shutdown Cooling } \\
\text { Component } \\
\text { or Discontinuity } \\
\end{array}$ & 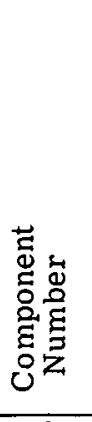 & 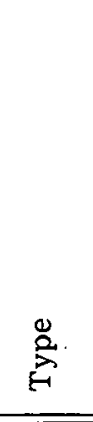 & 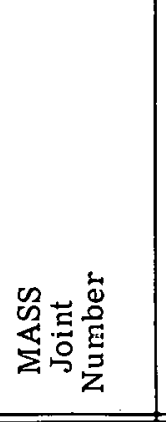 & 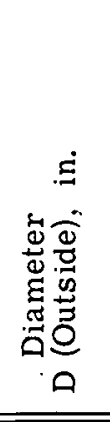 & 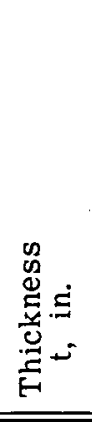 & 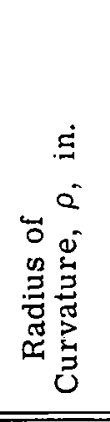 & $\stackrel{*}{2}$ & 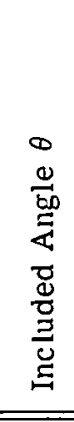 & 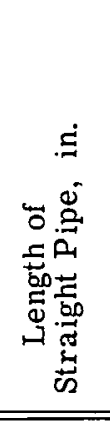 & 㞼 & 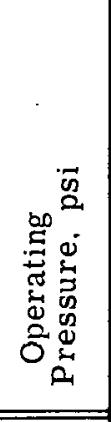 & 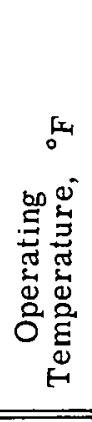 & 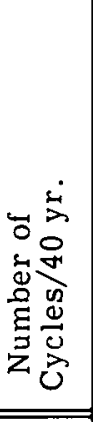 & 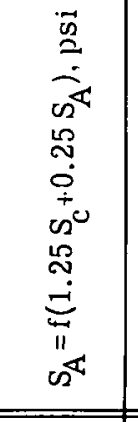 & 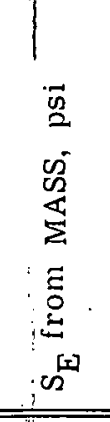 & 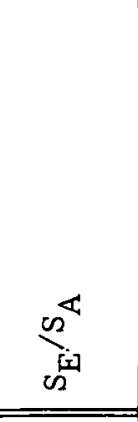 & 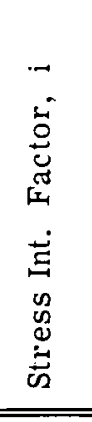 & 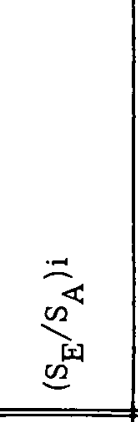 & $\underbrace{\stackrel{x}{\rightleftarrows}}_{4}$ & 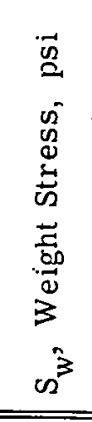 & 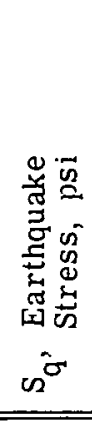 \\
\hline Elbow & 935 & 2 & 513-514 & 14.0 & 0.75 & 21,0 & 1.5 & $90^{\circ}$ & & $\begin{array}{l}\text { Welded } \\
304\end{array}$ & 1000 & 146 & 360 & 26,100 & 4433 & 0.1698 & & 0.1698 & 0.2707 & 1746 & 6342 \\
\hline Weld & & D-1 & & & & & & & & & & & & & 4433 & 0.1698 & 1.0 & 0.1698 & & 980 & 3560 \\
\hline Straight & 936 & 1 & $514-515$ & 14.0 & 0.75 & & & & 101.3 & 304 & 1000 & 146 & 360 & 26.100 & 2509 & 0.0961 & & 0.0961 & 0.2707 & 616 & 1634 \\
\hline Valve Connection & & D-1 & 515 & & & & & & & & & & & & 631 & 0.0242 & 1.0 & 0.0242 & & 240 & 635 \\
\hline Valve & 937 & 4 & $515-516$ & 14.0 & 3.5 & & & & 42.0 & 304 & 1000 & 146 & 360 & 26,100 & 252 & 0.0097 & & 0.0097 & 0.0849 & 196 & 492 \\
\hline Valve Connection & & D-1 & 516 & & & & & & & & & & & & 649 & 0.0249 & 1.0 & 0.0249 & & 505 & 1265 \\
\hline Straight & 938 & 1 & $516-517$ & 14.0 & 0.75 & & & & 69.0 & 304 & 1000 & 146 & 360 & 26.100 & 1897 & 0.0727 & & 0.0729 & 0.2707 & 750 & 1835 \\
\hline Weld & & D-1 & 517 & & & & & & & & & & & & 3330 & 0.1276 & 1.0 & 0.1276 & & 1336 & 3261 \\
\hline Elbow & 939 & 2 & $517-518$ & 14.0 & 0.75 & 21.0 & 1.5 & $90^{\circ}$ & & 304 & 1000 & 146 & 360 & 26,100 & 3330 & 0.1276 & & 0.1276 & 0.2707 & 554 & 1943 \\
\hline Weld & & D-1 & & & & & & & & & & & & & $\dot{2} 247$ & 0.0861 & 1.0 & 0.0861 & & 512 & 1745 \\
\hline Straight. & 940 & 1. & $518-519$ & 14.0 & 0.75 & & & & 6.0 & 304 & 1000 & 146 & 360 & 26,100 & 2242 & 0.0859 & & 0.0859 & 0.2707 & 494 & 1717 \\
\hline Weld & & $D-1$ & & & & & & & & & & & & & 2252 & 0.0863 & 1.0 & 0.0863 & & 498 & 1836 \\
\hline Elbow & 941 & 2 & $519-520$ & 14.0 & 0.75 & 21.0 & 1.5 & $90^{\circ}$ & & 304 & 1000 & 146 & 360 & 26,100 & 4666 & 0.1788 & & 0.1788 & 0.2707 & 905 & 2182 \\
\hline Weld & & D-1 & & & & & & & & & & & & & 4666 & 0.1788 & 1.0 & 0.1788 & & 807 & 1224 \\
\hline Straight & 942 & 1 & $520-521$ & 14.0 & 0.75 & & & & 58.9 & 304 & 1000 & 146 & 360 & 26.100 & 3482 & 0.1334 & & 0.1334 & 0.2707 & 2809 & 101 \\
\hline Drywell Penetration & & $\mathrm{D}-2$ & 521 & & & & & & & & & & & & 3482 & 0.1334 & & 0.1334 & & 2809 & 0 \\
\hline $\begin{array}{l}\text { Model Number } 8 \\
\text { to Shutdown Cooling }\end{array}$ & & & & & & & & & & & & & & & & & & & & & \\
\hline $\begin{array}{l}14 \text { in. } \times 26 \text { in. Tee in } \\
\text { Recirculation Line No. } 5\end{array}$ & & D-4 & 437 & & & & & & & Id & & & & & 9262 & 0.3549 & 1.22 & 0.4330 & & 4430 & 3247 \\
\hline $\begin{array}{l}\text { Branch of Tee } 437 \\
\text { Run of Tee } 451\end{array}$ & 943 & 1 & $437-451$ & 14.0 & 0.75 & & & & 30.0 & 304 & 1000 & 146 & 360 & 26.100 & 9262 & 0.3549 & & 0.4330 & 0.2707 & 2848 & 1866 \\
\hline $\begin{array}{l}10 \text { in. } \times 14 \text { in } \\
\text { E.C.C. No. }\end{array}$ & & $\mathrm{D}-4$ & & & & & & & & & & & & & 7576 & 0.3903 & 1.49 & 0.5815 & & 1411 & 2024 \\
\hline Run of Tee 451 & 944 & 1 & $451-501$ & 14.0 & 0.75 & & & & 26.0 & 304 & 1000 & 146 & 360 & 26,100 & 7576 & 0.3903 & & 0.5815 & 0.2707 & 798 & 1241 \\
\hline Valve Connection & & $\mathrm{D}-1$ & 501 & & & & & & & & & & & & 5830 & 0.2234 & 1.0 & 0.2234 & & 310 & 482 \\
\hline Valve & 945 & 4 & $501-502$ & 14.0 & 0.35 & & & & 42.0 & 304 & 1000 & 146 & 360 & 26,100 & 2676 & 0.1025 & & 0.1025 & 0.0849 & 413 & 230 \\
\hline Valve Connection & & D-1 & & & & & & & & & & & & & 6882 & 0.2637 & 1.0 & 0.2637 & & 1062 & 592 \\
\hline Straight & 946 & 1 & $502-503$ & 14.0 & 0.75 & & & & 8.0 & 304 & 1000 & 146 & 360 & 26,100 & 7555 & 0.2995 & & 0.2995 & 0.2707 & 1046 & 609 \\
\hline Weld & & D-1 & 503 & & & & & & & & & & & & 11690 & 0.4479 & 1.0 & 0.4479 & & 1451 & 979 \\
\hline Elbow & 947 & 2 & $503-504$ & 14.0 & 0.75 & 21.0 & 1.5 & $90^{\circ}$ & & 304 & 1000 & 146 & 360 & 26.100 & 11690 & 0.4479 & & 0.4479 & 0.2707 & 1579 & 821 \\
\hline Weld & & D-1 & 504 & & & & & & & & & & & & 9195 & 0.3523 & 1.0 & 0.3523 & & 1579 & 492 \\
\hline
\end{tabular}




\begin{tabular}{|c|c|c|c|c|c|c|c|c|c|c|c|c|c|c|c|c|c|c|c|c|c|}
\hline $\begin{array}{l}\text { Model Number } 8 \\
\text { to Shutdown Cooling } \\
\text { (Continued) } \\
\text { Component } \\
\text { or Discontinuity }\end{array}$ & 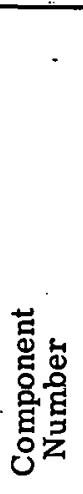 & $\sum_{H}^{\circ}$ & 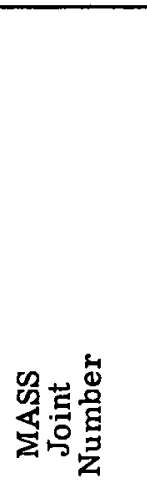 & 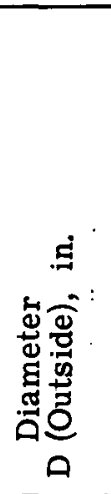 & 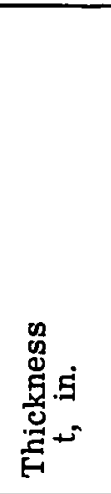 & 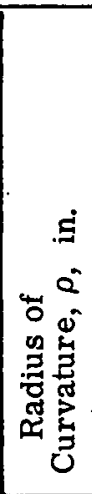 & $\stackrel{*}{a}$ & 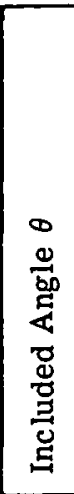 & 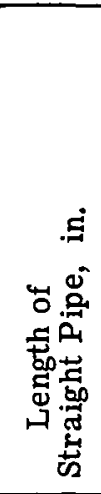 & 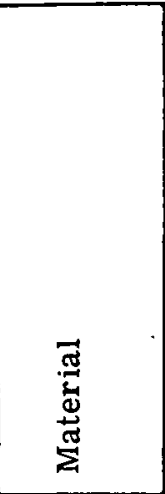 & 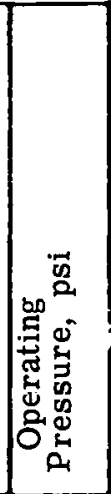 & 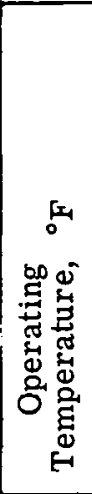 & 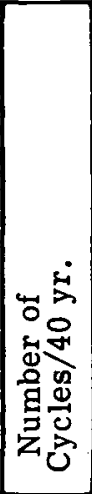 & 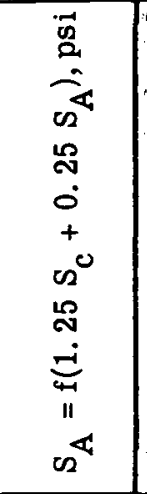 & 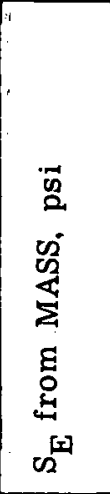 & $\cos ^{\sqrt[5]{4}}$ & 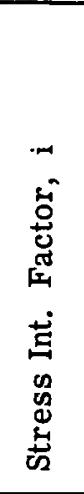 & 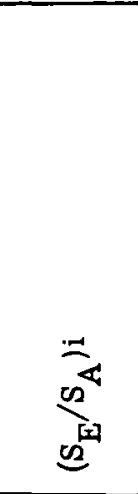 & $\int_{4}^{a}$ & 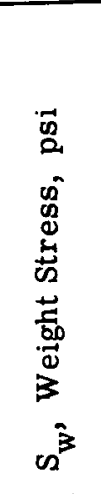 & 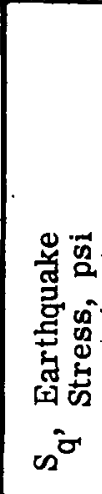 \\
\hline $\begin{array}{l}\text { Straight } \\
\text { Weld } \\
\text { Elbow } \\
\text { Weld } \\
\text { Elbow } \\
\text { Weld } \\
\text { Straight } \\
\text { Drywell Penetration } \\
\end{array}$ & $\begin{array}{l}948 \\
949 \\
950 \\
951\end{array}$ & $\begin{array}{c}1 \\
D-1 \\
2 \\
D-1 \\
2 \\
D-1 \\
1 \\
D-2 \\
\end{array}$ & $\begin{array}{l}504-505 \\
505 \\
505-506 \\
506 \\
506-507 \\
507 \\
507-508 \\
508 \\
\end{array}$ & $\begin{array}{l}14.0 \\
14.0\end{array}$ & $\begin{array}{l}0.75 \\
0.75\end{array}$ & 21.0 & 1.5 & $\begin{array}{l}90^{\circ} \\
90^{\circ}\end{array}$ & 92.3 & \begin{tabular}{|l|} 
Welded \\
304 \\
304
\end{tabular} & $\left|\begin{array}{l}1000 \\
1000 \\
1000 \\
1000\end{array}\right|$ & $\begin{array}{l}146 \\
146\end{array}$ & $\begin{array}{l}360 \\
360\end{array}$ & $\begin{array}{l}26,100 \\
26,100 \\
26,100 \\
26,100\end{array}$ & \begin{tabular}{|r|}
7001 \\
8241 \\
8241 \\
7941 \\
11240 \\
11240 \\
6500 \\
3436 \\
\end{tabular} & $\begin{array}{l}0.2682 \\
0.3157 \\
0.3157 \\
0.3043 \\
0.4307 \\
0.4307 \\
0.2490 \\
0.1316 \\
\end{array}$ & $\begin{array}{l}1.0 \\
1.0 \\
1.0 \\
1.0\end{array}$ & $\begin{array}{l}0.2682 \\
0.3157 \\
0.3157 \\
0.3043 \\
0.4307 \\
0.4307 \\
0.2490 \\
0.1316 \\
\end{array}$ & $\begin{array}{l}0.2707 \\
0.2707 \\
0.2707 \\
0.2707\end{array}$ & $\begin{array}{r}894 \\
767 \\
1351 \\
597 \\
327 \\
470 \\
2797 \\
2797 \\
\end{array}$ & $\begin{array}{r}382 \\
606 \\
406 \\
406 \\
480 \\
269 \\
0 \\
0\end{array}$ \\
\hline \multicolumn{22}{|l|}{$\begin{array}{l}\text { Model Number } 8 \\
\text { Emergency Condenser } \\
\text { Condensate }\end{array}$} \\
\hline $\begin{array}{l}10 \mathrm{in.} \text { Branch of Tee } 451 \\
\text { Valve Connection }\end{array}$ & 952 & $\begin{array}{c}1 \\
D-1\end{array}$ & $\begin{array}{l}451-452 \\
452\end{array}$ & 10.75 & 0.593 & & & & 54.2 & $\underset{304}{\text { Seamless }}$ & 1000 & 157 & 500 & 26,100 & \begin{tabular}{|l|}
4622 \\
3844
\end{tabular} & $\begin{array}{l}0.1771 \\
0.1473\end{array}$ & 1.0 & $\begin{array}{l}0.2639 \\
0.1473\end{array}$ & 0.1585 & $\begin{array}{l}7419 \\
3048\end{array}$ & $\begin{array}{r}3496 \\
867\end{array}$ \\
\hline Valve & 953 & 4 & $452-453$ & 10.75 & 2.5 & & & & 36.0 & 304 & 1000 & 157 & 500 & 26,100 & 1564 & 0.0599 & & 0.0599 & 0.0582 & 1240 & 353 \\
\hline $\begin{array}{l}\text { Valve Connection } \\
\text { Straight }\end{array}$ & 954 & $\begin{array}{c}\mathrm{D}-1 \\
1\end{array}$ & $\begin{array}{l}453 \\
453-454\end{array}$ & 10.75 & 0.593 & & & & 51.4 & 304 & 1000 & 157 & 500 & 26,100 & $\begin{array}{l}3399 \\
3399\end{array}$ & $\begin{array}{l}0.1302 \\
0.1302\end{array}$ & 1.0 & $\begin{array}{l}0.1302 \\
0.1302\end{array}$ & 0.1585 & $\begin{array}{r}542 \\
1332\end{array}$ & $\begin{array}{l}178 \\
437\end{array}$ \\
\hline Weld & 955 & $\begin{array}{c}\mathrm{D}-1 \\
2\end{array}$ & & & & & & & & & & & & & 5118 & 0.1961 & 1.0 & 0.1961 & 01585 & 572 & $\begin{array}{l}1435 \\
2624\end{array}$ \\
\hline $\begin{array}{l}\text { Elbow } \\
\text { Weld }\end{array}$ & 955 & $\begin{array}{c}2 \\
D-1\end{array}$ & $\begin{array}{l}454-455 \\
455\end{array}$ & 10.75 & 0.593 & 15.0 & 1.5 & $90^{\circ}$ & & 304 & $\mid 1000$ & 157 & 500 & 26,100 & $\begin{array}{l}5118 \\
3519\end{array} \mid$ & $\begin{array}{l}0.1961 \\
0.1348\end{array}$ & 1.0 & $\begin{array}{l}0.1961 \\
0.1348\end{array}$ & 0.1585 & $\begin{array}{l}969 \\
473\end{array}$ & $\begin{array}{l}2624 \\
2785\end{array}$ \\
\hline Straight & 956 & $\begin{array}{l}1 \\
D-1\end{array}$ & $455-456$ & 10.75 & 0.593 & & & & 83.9 & 304 & 1000 & 157 & 500 & 26,100 & $\begin{array}{l}2448 \\
3467\end{array}$ & 0.0938 & 10 & $\begin{array}{l}0.0938 \\
0.1328\end{array}$ & 0.1585 & 414 & 1526 \\
\hline $\begin{array}{l}\text { Weld } \\
\text { Elbow }\end{array}$ & 957 & $\begin{array}{c}D-1 \\
2\end{array}$ & $456-457$ & 10.75 & 0.593 & 15.0 & 1.5 & $90^{\circ}$ & & 304 & 1000 & 157 & 500 & 26,100 & 4633 & 0.1775 & & 0.1775 & 0.1585 & 747 & 1124 \\
\hline Weld & & D-1 & 457 & & & & & & & & & & & & 4633 & 0.1775 & 1.0 & 0.1775 & & 657 & 582 \\
\hline Straight & 958 & 1 & $457-458$ & 10.75 & 0.593 & & & & 83.8 & 304 & 1000 & 157 & 500 & 26,100 & 2532 & 0.0970 & & 0.0970 & 0.1585 & 570 & 467 \\
\hline Weld & & D-1 & & & & & & & & & & & & & 1863 & 0.0714 & 1.0 & 0.0714 & & 1855 & 740 \\
\hline Elbow & 959 & 2 & $458-459$ & 10.75 & 0.593 & 15.2 & 1.5 & $90^{\circ}$ & & 304 & 1000 & 157 & 500 & $26,100^{3}$ & 1863 & 0.0714 & & 0.0714 & 0.1585 & 3269 & 561 \\
\hline Weld & & D-1 & 459 & & & & & & & & & & & & 897 & 0.0344 & 1.0 & 0.0344 & & 2296 & 533 \\
\hline Straight & 960 & 1 & $459-460$ & 10.75 & 0.593 & & & & 10.6 & 304 & 1000 & 157 & 500 & $26,100^{\prime}$ & 997 & 0.0382 & & 0.0382 & 0.1585 & 2296 & 304 \\
\hline Hanger and Weld & & $D-1 \& 2$ & 460 & & & & & & & & & & & & 1434 & 0.0549 & 1.0 & 0.0549 & & 2328 & 430 \\
\hline Elbow & 961 & 2 & $460-461$ & 10.75 & 0.593 & 15.0 & 1.5 & $90^{\circ}$ & & 304 & 1000 & 157 & 500 & $\left|26,100^{\circ}\right|$ & $\mid 1829$ & 0.0701 & & 0.0701 & 0.1585 & 2401 & 645 \\
\hline
\end{tabular}




\begin{tabular}{|c|c|c|c|c|c|c|c|c|c|c|c|c|c|c|c|c|c|c|c|c|c|}
\hline $\begin{array}{l}\text { Model Number } 8 \\
\text { Emergency Condenser } \\
\text { Condensate (Continued) } \\
\text { Component } \\
\text { or Discontinuity }\end{array}$ & 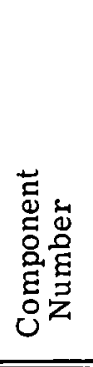 & 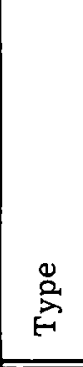 & 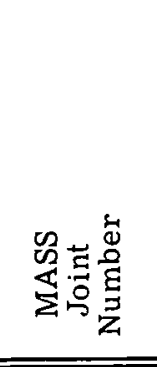 & 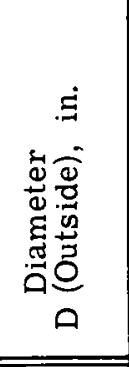 & 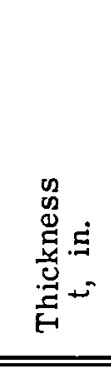 & 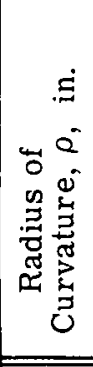 & $\stackrel{*}{\stackrel{*}{Q}}$ & 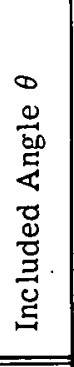 & 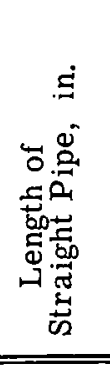 & 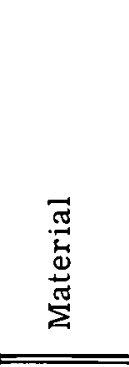 & 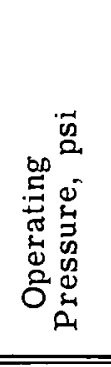 & 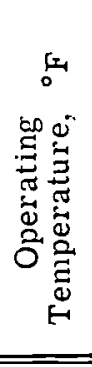 & 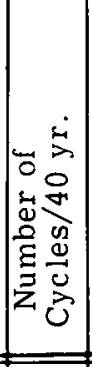 & 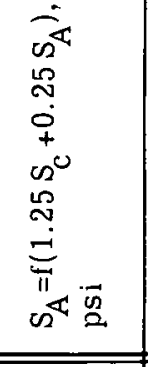 & 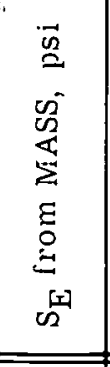 & $\underbrace{\sqrt{4}}_{\text {w }}$ & 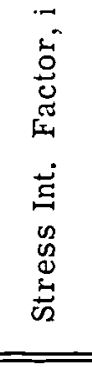 & 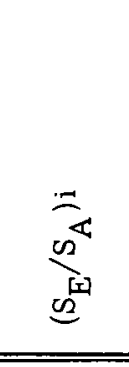 & 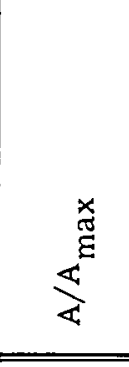 & 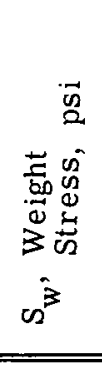 & 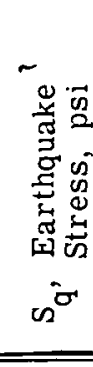 \\
\hline Weld & & D-1 & 461 & & & & & & & $\begin{array}{l}\text { Seam- } \\
\text { less }\end{array}$ & & & & & 1829 & 0.0701 & 1.0 & 0.0701 & & 4324 & 1036 \\
\hline Straight & 962 & 1 & $461-462$ & 10.75 & 0.593 & & & & 243.1 & $\begin{array}{r}1+5 s \\
304 \\
304\end{array}$ & 1000 & 157 & 500 & 26,100 & 5216 & 0.1998 & & 1998 & 0.1585 & 2369 & 614 \\
\hline Valve Connection & & D-1 & & & & & & & & & & & & & 5216 & 0.1998 & 1.0 & 0.1998 & & 1289 & 2748 \\
\hline Valve & 963 & 4 & $462-463$ & 10.75 & 0.593 & & & & 33.0 & 304 & 1000 & 157 & 500 & 26.100 & 413 & 0.0158 & & 0.0158 & 0.1585 & 598 & 2324 \\
\hline Valve Connection & & D-1 & 463 & & & & & & & & & & & & 791 & 0.0303 & 1.0 & 0.0303 & & 152 & 1755 \\
\hline Straight & 964 & 1 & $463-464$ & 10.75 & 0.593 & & & & 28.0 & 304 & 1000 & 157 & 500 & 26,100 & 791 & 0.0303 & & 0.0303 & 0.1585 & 373 & 4313 \\
\hline Bend & 965 & 3 & $464-465$ & 10.75 & 0.593 & 47.6 & 4.8 & $46^{\circ}$ & & 304 & 1000 & 157 & 500 & 26.100 & 663 & 0.0254 & & 0.0254 & 0.1585 & 27 & 3539 \\
\hline Straight & 966 & 1 & $465-466$ & 10.75 & 0.593 & & & & 174.0 & 304 & 1000 & 157 & 500 & 26.100 & 803 & 0.0308 & & 0.0308 & 0.1585 & 147 & 3812 \\
\hline Bend & 967 & 3 & $466-467$ & 10.75 & 0.593 & 48.3 & 4.8 & $90^{\circ}$ & & 304 & 1000 & 157 & 500 & 26,100 & 803 & 0.0308 & & 0.0308 & 0.1585 & 263 & 1235 \\
\hline Hanger & & D-2 & 467 & & & & & & & & & & & & 244 & 0.0093 & 1.0 & 0.0093 & & 1438 & 1674 \\
\hline Straight & 968 & 1 & $467-468$ & 10.75 & 0.593 & & & & 19.3 & 304 & 1000 & 157 & 500 & 26.100 & 361 & 0.0138 & & 0.0138 & 0.1585 & 815 & 1723 \\
\hline Bend & 969 & 3 & $468-469$ & 10.75 & 0.593 & 48.3 & 4.8 & $90^{\circ}$ & & 304 & 1000 & 157 & 500 & 26,100 & 1009 & 0.0387 & & 0.0387 & 0.1585 & 400 & 2107 \\
\hline Straight & 970 & 1 & $469-470$ & 10.75 & 0.593 & & & & 252.2 & 304 & 1000 & 157 & 500 & 26,100 & 1336 & 0.0512 & & 0.0512 & 0.1585 & 400 & 1555 \\
\hline Bend & 971 & 3 & $470-471$ & 10.75 & 0.593 & 48.0 & 4.8 & $90^{\circ}$ & & 304 & 1000 & 157 & 500 & 26,100 & 1429 & 0.0548 & & 0.0548 & 0.1585 & 560 & 1063 \\
\hline Hanger & & $\mathrm{D}-2$ & 471 & & & & & & & & & & & & 1429 & 0.0548 & 1.0 & .0548 & & 1385 & 1317 \\
\hline Straight & 972 & 1 & $471-472$ & 10.75 & 0.593 & & & & 24.0 & |304 & 1000 & 157 & 500 & 26.100 & 1564 & 0.0599 & & 0.0599 & 0.1585 & 789 & 131.7 \\
\hline Bend & 973 & 3 & $472-473$ & 10.75 & 0.593 & 48.0 & 4.8 & $90^{\circ}$ & & |304 & 1000 & 157 & 500 & 26,100 & 1724 & 0.0661 & & 0.0661 & 0.1585 & 594 & 2251 \\
\hline Straight & 974 & 1 & $473-474$ & 10.75 & 0.593 & & & & 84.0 & 304 & 1000 & 157 & 500 & 26,100 & 1803 & 0.0691 & & 0.0691 & 0.1585 & 594 & 2156 \\
\hline Bend & 975 & 3 & $474-475$ & 10.75 & 0.593 & 48.0 & 4.8 & $90^{\circ}$ & & 304 & 1000 & 157 & 500 & 26,100 & 2062 & 0.0790 & & 0.0790 & 0.1585 & 771 & 1818 \\
\hline Hanger & & $\mathrm{D}-2$ & 475 & & & & & & & & & & & & 2031 & 0.0778 & 1.0 & 0.0778 & & 771 & 1818 \\
\hline $10 \mathrm{in.}$ Branch of Tee 476 & 076 & 1 & $475-476$ & 10.75 & 0.593 & & & & 78.0 & 304 & 1000 & 157 & 500 & 26.100 & 2140 & 0.0782 & & 0.1193 & 0.1585 & 252 & 2847 \\
\hline 8 in. $\times 10$ in。 Tee & & D-4 & 476 & & & & & & & & & & & & 2208 & 0.0846 & 1.41 & 0.1193 & & 535 & 4653 \\
\hline $8 \mathrm{in}$. Run of Tee 476 & 977 & 1 & $476-477$ & 8.624 & 0.50 & & & & 56.4 & 304 & 1000 & 157 & 500 & 26,100 & 2208 & 0.0846 & & 0.1193 & 0.1007 & 317 & 2635 \\
\hline Bend & 978 & 3 & $477-478$ & 8.624 & 0.50 & 48.0 & 6.0 & $90^{\circ}$ & & 304 & 1000 & 157 & 500 & 26,100 & 1121 & & & .0403 & 0.1007 & 333 & 931 \\
\hline Straight & 979 & 1 & $478-479$ & 8.624 & 0.50 & & & & 52.8 & 304 & 1000 & 157 & 500 & 26.100 & 1896 & 0.0726 & & 0.0706 & 0.1007 & 83 & 3389 \\
\hline Weld & & $\mathrm{D}-1$ & 479 & & & & & & & & & & & & 2884 & 0.1105 & 1.41 & 0.1105 & & 125 & 5121 \\
\hline Elbow & 980 & 2 & $479-480$ & 8.624 & 0.50 & 15.0 & 1.9 & $60^{\circ}$ & & 304 & 1000 & 157 & 500 & 26,100 & 2976 & 0.1140 & & 0.1140 & 0.1007 & 515 & 6545 \\
\hline Weld & & $\mathrm{D}-1$ & 480 & & & & & & & & & & & & 2766 & 0.1060 & 1.41 & 0.1060 & & 353 & 4300 \\
\hline Straight & 981 & 1 & $480-481$ & 8.624 & 0.50 & & & & 10.8 & 304 & 1000 & 157 & 500 & 26,100 & 2019 & 0.0774 & & 0.0774 & 0.1007 & 859 & 4455 \\
\hline Condenser & & D-1 & & & & & & & & & & & & & 1822 & 0.0698 & 1.41 & 0.0698 & & 859 & 4.455 \\
\hline $8 \mathrm{in}$ Run of Tee 476 & 987 & 1 & $476-487$ & 8.624 & 0.50 & & & & 87.6 & & 1000 & 157 & 500 & 26,100 & 1822 & 0.0698 & & 0.1193 & 0.1007 & 114 & 2906 \\
\hline Bend & 988 & 3 & $487-488$ & 8.624 & 0.50 & 48.0 & 6.0 & $90^{\circ}$ & & 304 & 1000 & 157 & 500 & 26,100 & 1755 & 0.0672 & & 0.0672 & 0.1007 & 254 & 2221 \\
\hline Straight & 989 & 1 & $488-489$ & 8.624 & 0.50 & & & & 52.8 & 304 & 1000 & 157 & 500 & 26,100 & 1954 & 0.0748 & & 0.0748 & 0.1007 & 304 & 910 \\
\hline Weld & & $D-1$ & 489 & & & & & & & & & & & & 2960 & 0.1134 & 1.41 & 0.1134 & & 123 & 2526 \\
\hline Elbow & 990 & 2 & $489-490$ & 8.624 & 0.50 & & & & 52.8 & 304 & 1000 & 157 & 500 & 26,100 & 2960 & 0.1134 & & 0.1134 & 0.1007 & 183 & 3835 \\
\hline Weld & & D-1 & 490 & & & & & & & & & & & & 2794 & 0.1070 & 1.41 & 0.1070 & & 687 & 4364 \\
\hline Straight & 991 & 1 & $490-401$ & 8.624 & 0.50 & & & & 10.8 & 304 & 1000 & 157 & 500 & 26,100 & 2327 & 0.0890 & & 0.0890 & 0.1007 & 468 & 3425 \\
\hline Condenser Attachn & & $D-1$ & 491 & & & & & & & & & & & & 2937 & 0.1125 & 1.41 & 0.1125 & & 1059 & 3624 \\
\hline
\end{tabular}


1. "Pipe Hanger Design and Engineering," Grinnell Corporation, 1964.

2. American Institute of Steel Construction - Manual.

3. American Standard Code for Pressure Piping, ASA B31. 1 - 1955.

4. General Electric Design Specification for Piping and Valve 22A1045.

5. "Earthquake History of the United States, " Part I, U. S. Coast and Geodetic Survey, Eastern Resume of Earthquake History.

6. Housner, G. W., "Behavior of Structures During Earthquakes," Proc. ASCE, J. Eng. Mech. Div., pp. 109129.

7. Beitch, L., "MASS - Digital Computer Program for Static and Dynamic Analysis of General Structures, " April 27, 1964, TIS No. R64FPD93 (General Electric Company proprietary information).

8. Moody, F. J., NUSA-167 "Impact Prcssure from High Speed Fluid Slugs," July 30, 1965 (Internal GE Memo).

9. G. E. Drawing 885D941, "Nozzle Thermal Cycles," September 1965.

10. Desai, M. P., "Reactor Vessel Nozzle and Auxiliary System Temper- ature Cycles, Design Guide, " GE Memo DA-10, October 25, 1966.

11. LeFort, P. N., "Stress Analysis of the Tarapur Isolation Condenser at the 8-inch Inlet Nozzle, "GE Memo SAR-6, October 17, 1966.

12. Schneider, P. J., "Temperature Response Charts," John Wiley \& Sons, Inc., New York, 1963.

13. "Design of Piping Systems, " M. W. Kellog Co., John Wiley \& Sons, Inc., New York, 1956.

14. Internal APED Memo, "Pipe Vibration Stress," J. E. Corr to S. W. Tagart, March 29, 1967.

15. Wilson, S. A., "Reliability Engineering, Sixth Quarterly Progress Report, Pipe Rupture Study, " GEAP-5279.

16. Krempl, E., "Low-Cycle Fatigue Strength Reduction in Notched Flat Plates," GEAP-5410, January 1967.

17. "Criteria of Section III of the ASME Boiler and Pressure Vessel Code for Nuclear Vessels," 1964.

18. Goldfarb, A. O., and Beilch, L. , "FAST II - Digital Computer Program for the Analysis of Space Structures, " December 17, 1962, TIS No. R62 FPD391. 


\section{DISTRIBUTION}

Copies

Copies

Aerojet General

1

P. O. Box 1845

Idaho Falls, Idaho 83401

Attn: W. E. Nyer

Advisory Committee on Reactor

Safeguards

Dr. Spencer H. Bush

Consultant to the Director

Battelle Memorial Institute

Pacific Northwest Laboratory

Richland, Washington

Advisory Committee on Reactor

Safeguards

$\mathrm{Mr}$. Harold Etherington

84 Lighthouse Drive

Jupiter, Florida 33458

Advisory Committee on

Reactor Safeguards

Dr. William L. Faith

2540 Huntington Drive

San Marino, California 91108

Advisory Committee on

Reactor Safeguards

Dr. Franklin A. Gifford; Jr., Dir.

Atmospheric Turbulence and

Diffusion Laboratory, ESSA

c/o U.S. Atomic Energy Com.

P. O. Box E

Oak Ridge, Tennessee 37830

Advisory: Committee on

Reactor Safeguards

Dr. Stephen H: Hanauer

Professor of Nuclear Engineering

606 Dougherty Hall

University of Tennessee

Knoxville, Tennessee 37916

Advisory Committee on

Reactor Safeguards

Dr. Joseph M. Hendrie

Nuclear Engineering Department

Brookhaven National Laboratory

Upton, New York 11973

Advisory Committee on

Reactor Safeguards

Dr. Herbert S. Isbin

Department of Chemical Engineering

University of Minnesota

Minneapolis, Minnesota 55455

Advisory Committee on

Reactor Safeguards

Mr. Harold G. Mangelsdorf

78 Knollwood Road

Short Hills, New Jersey 07078

1
Advisory Committee on

1

Reactor Safeguards

Dr. Harry O. Monson

Senior Engineer

Laboratory Director's Office

Argonne National Laboratory

9700 South Cass Avenue

Argonne, Illinois 60439

Advisory Committee on Reactor

Safeguards

Dr. Arlie A. O'Kelly

2421 West Rowland Avenue

Littleton, Colorado 80120

Advisory Committee on

1

Reactor Safeguards

Dr. David Okrent

Senior Physicist

Laboratory Director's Office

Argonne National Laboratory

9700 South Cass Avenue

Argonne, Illinois 60439

Advisory Committee on

Reactor Safeguards

Dean Nunzio J. Palladino

College of Engineering

The Pennsylvania State University

101 Hammond Building

University Park, Pennsylvania 16802

Advisory Committee on

Reactor Safeguards

Dr. William R. Stratton

Los Alamos Scientific Laboratory

P. O. Box 1663

Los Alamos, New Mexico 87544

Advisory Committee on Reactor

Safeguards

Dr. Carroll W. Zabel

Director of Research

University of Houston

Cullen Boulevard

Houston, Texas 77004

Mr. Raymond F. Fraley

Executive Secretary

Advisory Committee on

Reactor Safeguards

U. S. Atomic Energy Commission

Room 1034-H

Washington D. C. 20545

1

Atomic Energy Commission

Division of Reactor Development

and Technology

Washington D. C. 20545

Attn: Mr. J. W. Crawford

Asst. Director for

Engineering Standards
3 
Argonne National Laboratory 9700 South Cass Avenue Argonne, Illinois:

Attn: Dr. P. Lottes

Dr. C. E. Dickerman

Dr. R. O. Ivins

Dr. S. Fistedis

Dr. R. C. Vogel

LMFBR Program Office

Mr. A. Amorosi

Dr. L. Baker

Atomic Energy Commission Division of Reactor Development and Technology

Washington, D. C. 20545

Attn: Col. R. L. Ednie

Asst. Director for Army Reactors

Atomic Energy Commission Division of Reactor Development and Technology

Washington D. C. 20545

Attn: Mr. M. $\Lambda$. Rosen Asst. Director for Plant Engineering

Atomic Energy Commission Division of Reactor Development and Technology

Washington D. C. 20545

Attn: Mr. M. J. Whitman Asst. Director for Program Analysis

Atumic Energy Commission Division of Reactor Development and Technology

Washington D. C. 20545

Attn: Dr. E. E. Sinclair Asst. Director for Reactor Technology

Atomic Energy Commission Division of Reactor Development and Technology

Washington D. C. 20545

Attn: Mr. A. Giambusson Asst. Director for Project Management

Atomic Energy Commissiun Division of Reactor Development and Technology

Washington D. C. 20545

Attn: Mr, E E Kintner

Asst. Director for

Reactor Engineering

IIT Research Institute

$10 \mathrm{~W}$. 35th Street

Chicago, Illinois 60616

Attn: Dr. T A Zaker

Mr. E. V. Gallagher
Atomic Energy Commission

Division of Compliance, Region IV

10395 West Colfax Avenue

Denver, Colorado 80215

Attn: Dr. Donald Walker

Atomic Energy Commission

Division of Compliance

Washington, D. C. 20545

Attn: Mr. L. Kornblith, Jr.

Atomic Energy Commission

Division of Operational Safety

Washington D. C. 20545

Attn: Mr. H. Gilbert

1

1

Atomic Energy Commission

Division of Reactor Standards

Washington D. C. 20545

Attn: Mr. E. G. Case

Mr. M. Bolotsky

Mr. A. B. Holt

Mr. R. Waterfield

Dr. G. Burley

Mr. J. J. DiNunno

Atomic Energy Commission

Water Projects Branch

Division of Reactor Development and Technology

Washington D. C. 20545

Attn: Mr. D. E. Erb

Atomic Energy Commission

Naval Reactors Branch

Division of Reactor Development and Technology

Washington D. C. 20545

Attn: Mr. R. S. Brodsky

Atomic Energy Commission

Division of Reactor Development and Technology

Washington D. C. 20545

Attn: Dr. J. A. Lieberman

Mr, S. A, Szawlewicz

Atomic Energy Commission

Division of Production

Washington D. C. 20545

Attn: Mr. George B. Pleat

Atomic Energy Commission $\mathrm{c} / \mathrm{O}$ Gulf General Atomic, Inc. P. O. Box 608

San Diego, California 92112

1

Attn: Mr. Russell H. Ball

Atomics International

P. O. Box 309

Canoga Park, California

Attn: Dr. H. Morewitz

Atomic Energy Commission

Maritime Reactors Branch 


\section{DISTRIBUTION (Continued)}

Copies

Babcock \& Wilcox Company

Washington Operations Office

1725 I Street, N.W.

Washington D. C. 20006

Attn: Mr. L. R. Weissert

Babcock \& Wilcox Company

P. O. Box 1260

Lynchburg, Virginia

Attn: Mr. Robert Wascher

Battelle Memorial Institute

505 King Avenue

Columbus, Ohio 43201

Attn: Dr. D. N. Sunderman

Dr. D. L. Morrison

Mr. S. Paprocki

Mr. A. R. Duffy

Brookhaven National Laboratory Upton, Long Island, New York 11973

Attn: A. W. Castleman

University of California

Office of Research Services

Berkeley, California 94720

Attn: Prof. V. E. Schrock

Canoga Park Area Office

P. O. Box 591

Canoga Park, California 91305

Attn: Mr. R. L. Morgan

RDT Senior Site Rep.

Combustion Engineering, Inc. Nuclear Division

P. O. Box 500

Windsor, Connecticut 06095

Attn: Mr. M. F. Valerino

Chicago Operations Office

Atomic Energy Commission

9800 South Cass Avenue

Argonne, Illinois 60439

Attn: Mr. D. M. Gardiner

Gulf General Atomic, Inc.

P. O. Box 608

San Diego, California 92112

Attn: Mr. A. J. Goodjohn

Harvard Air Cleaning Laboratory

Harvard University

665 Huntington Avenue

Boston, Massachusetts 02190

TRW Inc.

TRW Systems Group

One Space Park

Redondo Beach, California 90278

Attn: Dr. D. B. Langmuir

Mr. S. M. Zivi
Idaho Operations Office

Atomic Energy Commission

P. O. Box 2108

Idaho Falls, Idaho 83401

Attn: Mr. D. Williams

Liquid Metal Engineering Center

$\mathrm{c} / \mathrm{O}$ Atomics International

P. O. Box 309

Canoga Park, California 91304

Attn: R. W. Dickinson

Los Alamos Scientific Laboratory

P. O. Box 1663

Los Alamos, New Mexico 87544

Attn: Mr. J. H. Russel, $\mathrm{K}$ Division

MPR Associates, Inc.

1140 Connecticut Avenue, N.W.

Washington D. C. 20036

Attn: Mr. T. Rockwell, III Chairman AIF Safety Task Force

National Bureau of Standards

Washington D. C. 20545

Attn: Dr. C. Muehlhause

Naval Ordnance Laboratory

White Oak

Silver Springs, Maryland

Attn: Mr. James Proctor

North Carolina State University

Department of Mechanical Engineering

Raleigh, North Carolina 27607

Attn: Prof. M. N. Ozisik

Nuclear Fuels Services

West Valley, New York 14171

Attn: Mr. Russel P. Wischow

Oak Ridge Operations Office

Atomic Energy Commission

Oak Ridge, Tennessee 37830

Attn: Mr. W. L. Smalley

Oak Ridge National Laboratory

P. O. Box Y

Oak Ridge, Tennessee 37830

Nuclear Safety Information Center

Attn: Mr. Joel Buchanan

Oak Ridge National Laboratory

P. O. Box Y

Oak Ridge, Tennessee 37830

HTGR Program Coordination

Attn: Mr. D. B. Trauger

Chemical Technology Division

Oak Ridge National Laboratory

P. O. Box Y

Oak Ridge, Tennessee 37830

Attn: Mr. D. Ferguson

Mr. R. Blanco 


\section{DISTRIBUTION (Continued)}

Oak Ridge National Laboratory

P. O. Box Y

Oak Ridge, Tennessee

Attn: HTGR Safety Program Office Mr. W. B. Cottrell

Technical Information Division Oak Ridge National Laboratory P. O. Box X

Oak Ridge, Tennessee 37830

Attn: W. F. Ferguson

Pacific Northwest Laboratories P. O. Box 999

Richland, Washington 99352

Attn: Mr. G. Rogers

Mr. J. C. Spanner

Dr. J. Batch

Mr. R. Nightingale

Mr. L. Schwendiman

Phillips Petroleum Company

P. O. Box 1259

Idaho Falls, Idaho 83401

Attn: Mr. Curt Haire

Dr. S. Forbes

Mr. T. R. Wilson

Mr. N. K. Sowards

Water Reactor Safety Program Office

Manager, WRSPO

Richland Operations Office

P. O. Box 500

Richland, Washington 99352

Attn: Mr. C. Robinsion

Mr. A. S. Waterhouse

Mr. A. Brunstad

San Francisco Operations Office

Atomic Energy Commission

2111 Bancroft Way

Berkeley, California 94704

Attn: Mr. C. V. Backlund

Savannah Riber Laboratories

E. I. duPont deNemours \& Co.

Aiken, South Carolina 29802

Attn: Mr. A. H: Peters

Mr. H. K. Marks

Room 2N83, Department of the Navy

Washington, D. C.

H. Thielsch

140 Shaw Avenue

Cranston 5, Rhode Island

Commonwealth Edison Company

System Mechanical and Structural

Engineer

72 West Adams Street

Chicago, Illinois 60690

At:n: IN. A. Kershaw

4
Westinghouse Electric Corporation Atomic Power Division

P. O. Box 355

Pittsburgh, Pennsylvania 15230

Attn: Mr. R. A. Wiesemann

Dr. D. Fletcher

Dr. E. Beckjord

Dr. F. M. Heck

Dr. H. Graves

Westinghouse Electric Corporation Heat Transfer Division

Lester Branch Box 0175

Philadelphia, Pennsylvania 19113

Attn: Mr. A. Lohmeier

Southern Nuclcar Engineering, Inc. P. O. Box 10

Dunedin, Florida 33528

Attn: Mr. Gilbert Brown

Pacific Northwest Laboratories

P. O. Box 999

Richland, Washington 99352

Attn: E. R. Astley, Manger FFTF Project

Atomic Energy Commission Division of Reactor Standards

Washington, D. C. 20545

Attn: Mr. R. Impara

Oak Ridge National Laboratory

P. O. Box Y

Oak Ridge, Tennessee 37830

Attn: Mr. P. Rittenhouse

United Nuclear Corporation

Development Division

Grasslands Road

Elmsford, New York 10523

Attn: Dr. C. Graves

1. Mr. Edward T. Wessel

Research and Development Center Westinghouse Electric Corporation Beulah Road

Churchill Boro

Pittsburgh, Pennsylvania 15235

William E. Cooper

Lesselle and Associates

303 Bear Hill Road

Waltham, Massachusetts

Roger W. Staehle

Metallurgy Department

Ohio State University

Columbus, Ohio

1

Mr. Ralph Jones

Division of Reactor Development

U. S. Atomic Energy Commission Washington 25, D. C.

$$
\begin{aligned}
& 1 \\
& 1 \\
& 1 \\
& 1 \\
& 1
\end{aligned}
$$


$\therefore \quad$ GEAP-5724

DISTRIBUTION (Continued)

Copies

Copies

Mr. F. M. Moschine

Westinghouse Electric Company

Atomic Power Department

P. O. Box 355

Pittsburgh, Pennsylvania 15230

1

Robert Cloud

Bettis Atomic Power Laboratory

P. O. Box 79

West Mifflin, Pennsylvania 15122

Professor C. E. Taylor

Department of Theoretical and

Applied Mechanics

University of Illinois

Urbana, Illinois

1

Mr. E. Beauchamp-Nobbs

U. S. Marine Engineering Laboratory

Annapolis, Maryland

1

U. S. Atomic Energy Commission

Division of Technical Information

Extension

P. O. Box 62

Oak Ridge, Tennessee

3

U. S. Atomic Energy Commission

Division of Reactor Licensing

Washington, D. C. 20545

Attn: S. S. Pawlicki

USAEC Site Representative

General Electric Company

Sunnyvale, California 94086

Attn: Joel Levy, Senior

Site Representative

Mr. B. L. Greenstreet

P. O. Box Y

Oak Ridge National Laboratory

Oak Ridge, Tennessee

1

F. J. Witt

P. O. Box Y

ORNL - Oak Ridge, Tennessee

1

Commonwealth Edison Company

Dresden Nuclear Power Station

Rural Route 1

Morris, Illinois 60450

Attn: H. K. Hoyt

United Kingdom Atomic Energy

Authority

Reactor Materials Laboratory

Wigshaw Lane, Culcheth

Warrington, Lancs.

England

Attn: R. W. Nichols

1

Atomic Energy of Canada Limited Chalk River Nuclear Laboratories

Chalk River, Ontario, Canada 